Fernanda Campos de Oliveira

Avaliação da Interação entre o Persulfato de Potássio com Solos Brasileiros para a Utilização da Tecnologia de Remediação por Oxidação Química In Situ

São Paulo

2015 
Fernanda Campos de Oliveira

\section{Avaliação da Interação entre o Persulfato de Potássio com Solos Brasileiros para a Utilização da Tecnologia de Remediação por Oxidação Química In Situ}

Dissertação apresentada à escola Politécnica da Universidade de São Paulo para obtenção do título de Mestre em Engenharia

Área de Concentração:

Engenharia Química

Orientador: Professor Livre-Docente Claudio Augusto Oller do Nascimento

São Paulo 
Catalogação-na-publicação

\section{Oliveira, Fernanda Campos de}

Avaliação da interação entre o persulfato de potássio com solos brasileiros para a utilização da tecnologia de remediação por oxidação química in situ / F. C. Oliveira -versão corr. -- São Paulo, 2015.

p.

Dissertação (Mestrado) - Escola Politécnica da Universidade de São Paulo. Departamento de Engenharia Química.

1.Solos Remediação - Brasil 2.Oxidação I.Universidade de São Paulo. Escola Politécnica. Departamento de Engenharia Química Il.t. 
Dedico primeiramente a Deus por eu crer que toda minha intuição, esperança e determinação em realizar as minhas vontades só existem por causa dele. Dedico também este trabalho a minha família e ao meu noivo, Rogério da Silva Castro Vianna. 


\section{AGRADECIMENTOS}

Agradeço a Deus por ter me dado o privilégio em ter tido essa grande experiência, por ter me colocado em contato com pessoas muito especiais ao longo dessa caminhada. Agradeço a toda a minha família por fazerem parte da minha vida e por me apoiarem sempre. Agradeço ao meu noivo por ter sido quem mais me incentivou a iniciar o mestrado e a seguir em frente até o fim.

Agradeço em especial ao Prof. Dr. Claudio Augusto Oller do Nascimento por ter aceitado esta grande tarefa e responsabilidade em me orientar, agradeço a confiança depositada em mim e toda a sua ajuda e colaboração.

Agradeço a professora Dra. Juliana Gardenalli de Freitas pela co-orientação, por todo seu esforço e dedicação, por sua competência e capacidade em desenvolver pesquisa de qualidade com responsabilidade e segurança permitindo que eu pudesse desenvolver o trabalho com motivação e tranquilidade.

Gostaria de agradecer ao Prof. Dr. Neil R. Thomson da Universidade de Waterloo do Canadá por ter sido tão gentil durante toda sua contribuição com o trabalho. Agradeço especialmente por ter dividido sua vasta experiência e conhecimento sobre oxidação química in situ, além do auxílio dado no tratamento dos dados e todas outras contribuições.

Agradeço a todo o grupo de pesquisa Solo e Água da Unifesp Diadema por terem sido meus amigos dentro e fora do ambiente de trabalho e pela troca de experiência e contribuição. Carinho especial as professoras: Dra. Sheila Aparecida Correia Furquim e Dra. Miriam Chieko Shinzato, além do Prof. Dr. José Ermírio F. de Moraes pois sempre estiveram presentes contribuindo para o desenvolvimento da pesquisa. Agradeço também as alunas de iniciação científica, Renata de Melo Rollo, Kelly Hsia Tung, Maitê Bossi e Hana Okabe pelo comprometimento e dedicação com a pesquisa.

Agradeço a equipe de Ciências do Solo da ESALQ pela ajuda na execução de métodos específicos de análise do solo, em especial ao Prof. Dr. Reynaldo Ferracciú Alleoni, ao Engenheiro Florestal Mestre em Ciências do Solo Gabriel Ramatis Pugliese Andrade, ao Químico Luiz A. Silva Junior e a Eng. Agrônoma Marina Colzato.

Agradeço também ao Dr. Marcos Roberto Pinheiro do Laboratório de Pedologia do Departamento de Geográfia pela sua contribuição e a Fapesp a qual é financiadora do projeto de Remediação de solos e águas subterrâneas contaminadas por NAPLs utilizando oxidação química que tive a oportunidade em participar. 
" O pessimista vê dificuldade em cada oportunidade; o otimista vê oportunidade em cada dificuldade." 


\section{Sumário}

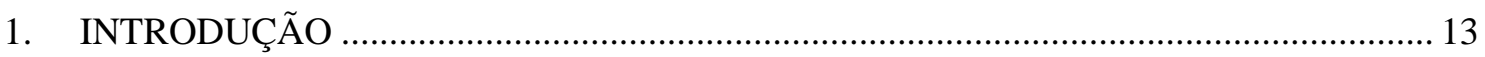

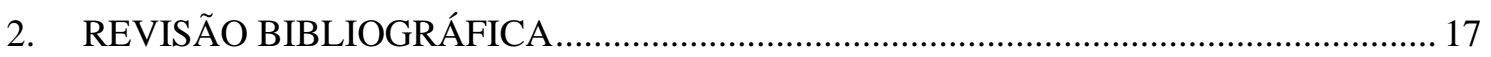

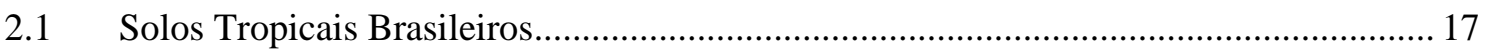

2.2 Remediação por Oxidação Química In Situ .................................................................... 21

2.3 Desafios para a Oxidação Química In Situ .................................................................... 23

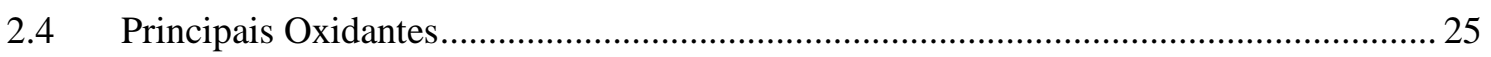

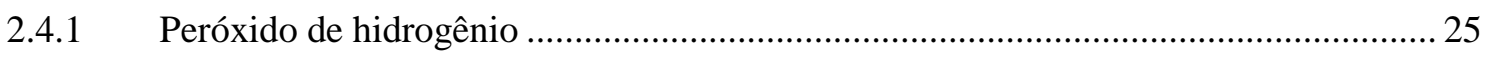

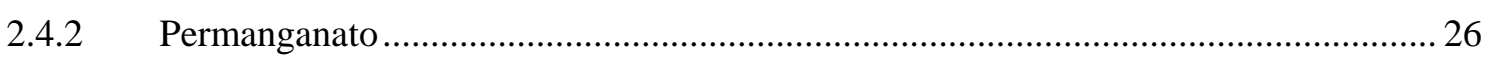

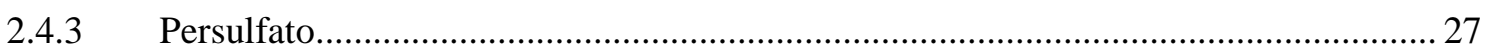

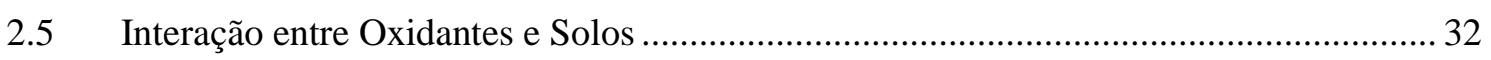

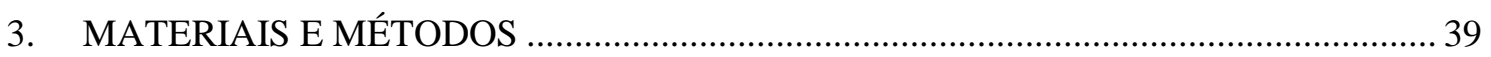

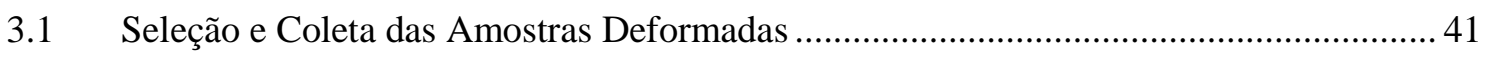

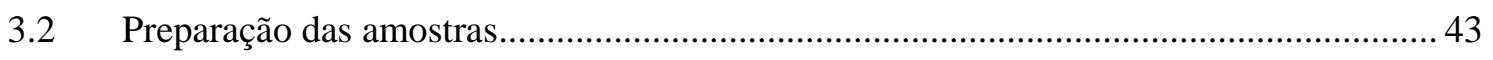

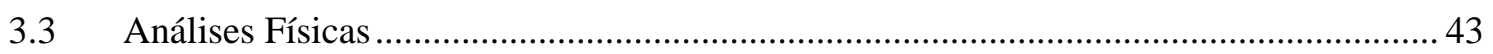

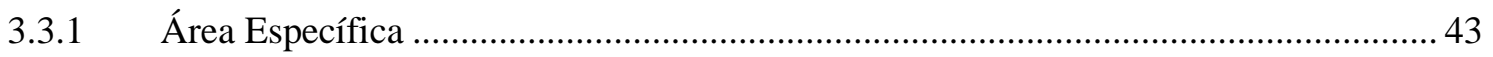

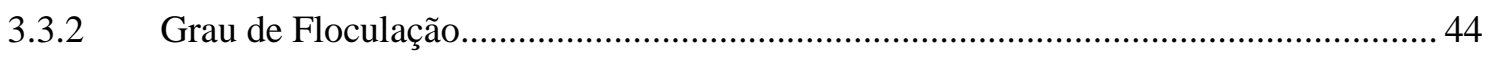

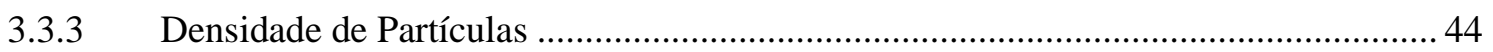

3.3.4 Densidade Aparente e Porosidade _..................................................................................... 45

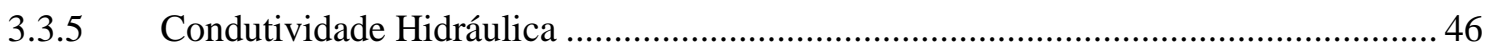

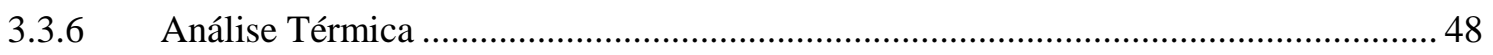

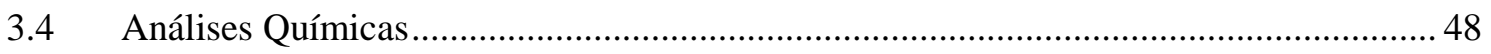

3.4.1 Capacidade de Troca Catiônica Efetiva e pH................................................................ 48

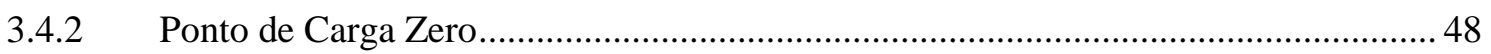

3.4.3 Carbono Total, Inorgânico e Orgânico …………………………………….................... 49

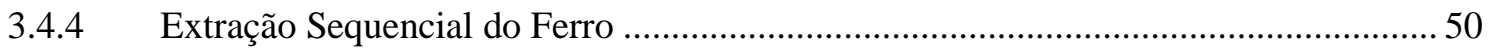

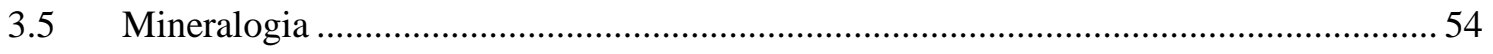

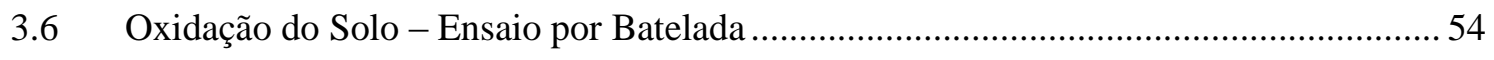

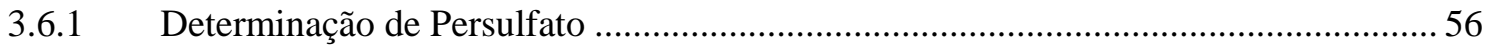

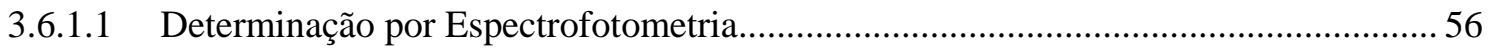

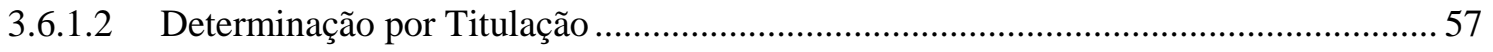

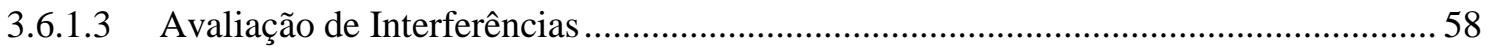

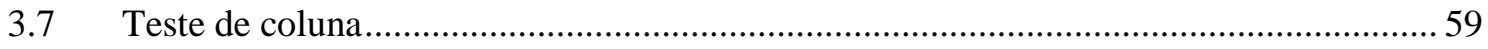

3.7.1 Seleção de Traçadores Conservativos ........................................................................... 59

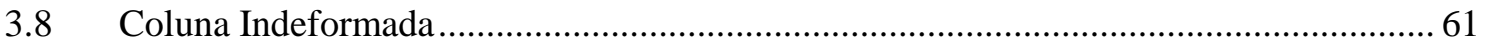




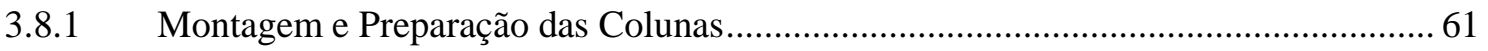

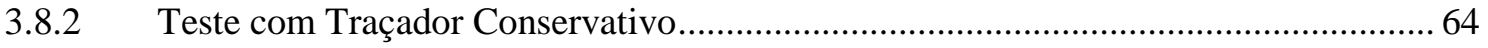

3.8.3 Oxidação das colunas e parâmetros monitorados ao longo da oxidação....................... 65

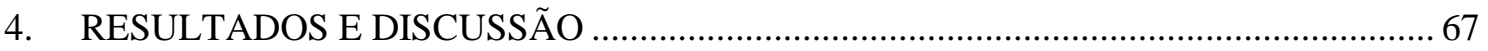

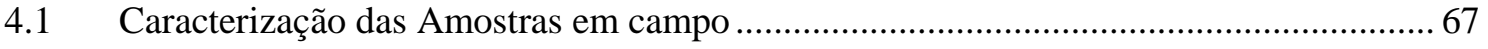

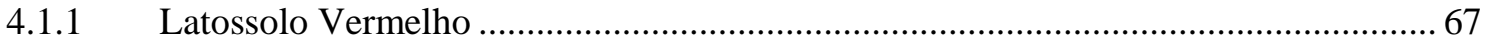

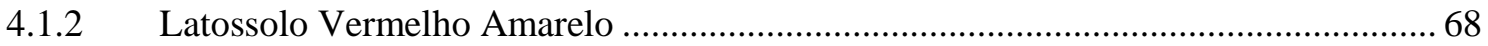

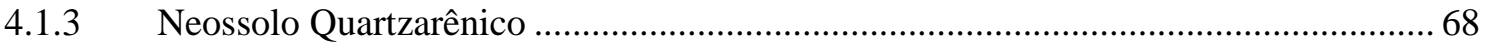

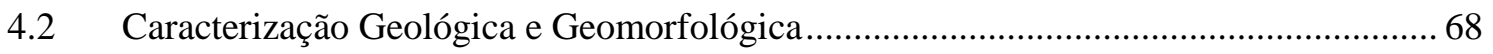

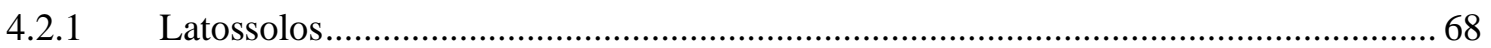

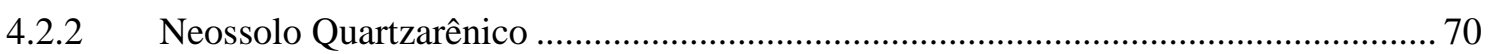

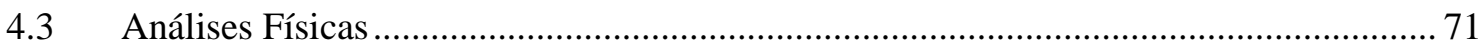

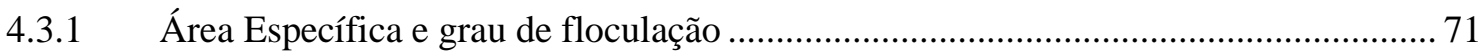

4.3.2 Densidade de Partículas, Densidade Aparente, Porosidade Total e Umidade.............. 72

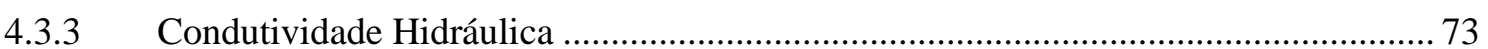

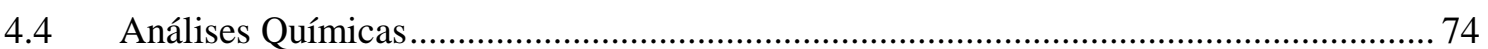

4.4.1 Cargas elétricas do solo, carbono total e inorgânico ....................................................... 74

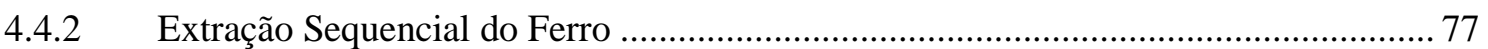

4.5 Mineralogia - Difração de Raio-X e Análise Termogravimétrica ...................................... 77

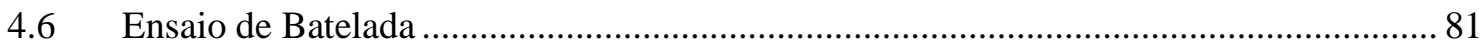

4.6.1 Método de Quantificação de Persulfato ................................................................................. 81

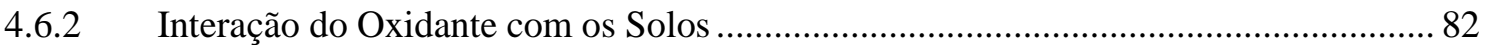

4.6.3 Potencial de Redução e pH da Solução dos Reatores ................................................... 87

4.7 Alteração nas Características Físicas dos Solos Pós-Oxidação.......................................... 90

4.8 Alteração nas Características Química dos Solos Pós-Oxidação ...................................... 92

4.8.1 Cargas Elétricas do Solo, Carbono Orgânico e Inorgânico, e Extração Sequencial do Ferro $\quad 92$

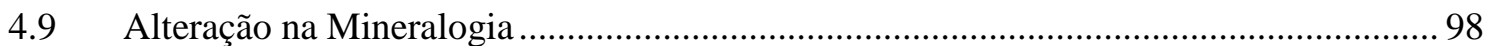

4.10 Oxidação do Latossolo Vermelho em Coluna Indeformada ........................................... 103

4.10.1 Avaliação do Traçador Conservativo - Fluoresceína ................................................... 103

4.10.2 Avaliação do Traçador Conservativo - Brometo.......................................................... 103

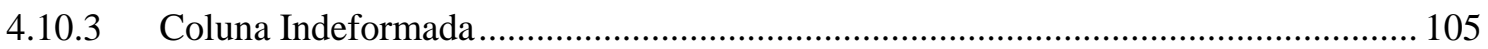

4.11 Interação do Oxidante e os Solos - Ensaio com Coluna Indeformada............................. 109

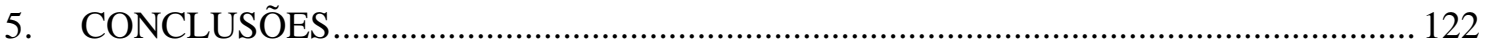

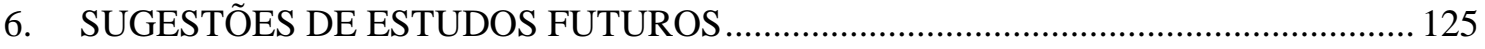

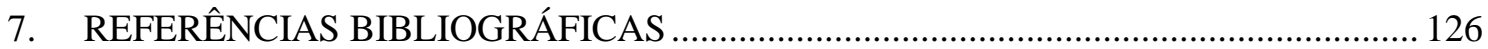




\section{INDICE DE FIGURAS}

Figura 1 - Mapa Pedológico do estado de São Paulo (OLIVEIRA et al., 1999)......................... 19

Figura 2 - Ocorrência do Latossolo Vermelho Não Férrico (esquerda) e Férrico (direita)

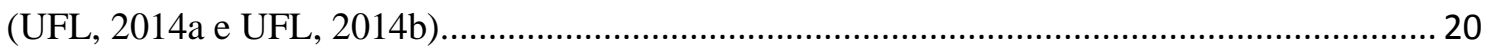

Figura 3 - Ocorrência do Latossolo Vermelho Amarelo no Brasil (UFL, 2014c)....................... 20

Figura 4 - Reação do persulfato com compostos orgânicos a) reação do radical sulfato com anel aromático; b) reação do radical sulfato com grupo amina; c) reação do radical sulfato com grupo

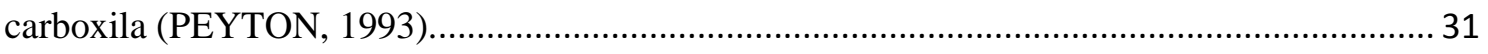

Figura 5 - Formação de radicais via ativação do persulfato (Fonte: Haizhou Liu, 2014)........... 37

Figura 6 - Fuxograma do experimento realacionado a oxidação por batelada. ........................... 39

Figura 7: Fluxograma do experimento realacionado a oxidação por coluna................................ 39

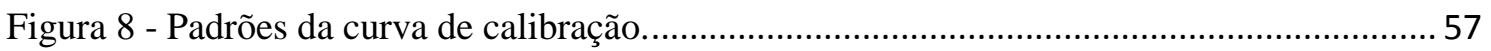

Figura 9 - Dimensões da coluna deformada utilizada para teste do traçador.............................. 60

Figura 10 - Dimensões da Coluna 1 e 2 com amostras indeformadas em seu interior ................ 63

Figura 11 - Colunas Indeformadas, Coluna 1 (esquerda) e a Coluna 2 (direita).......................... 64

Figura 12 - Divisão dos Horizontes do perfil do LV, LVA e NQ. ........................................... 67

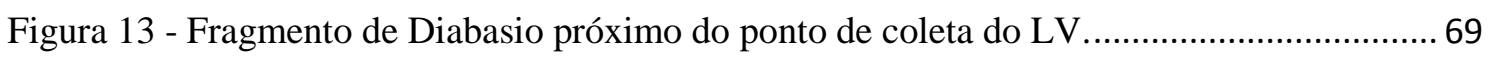

Figura 14 - Horizonte C do Latossolo Vermelho proveniente do Diabasio................................. 69

Figura 15 - Vista do ponto de coleta do Latossolo vermelho..................................................... 70

Figura 16 - Difratogramas da argila total das amostras do LVA, argila total do LV e argila total

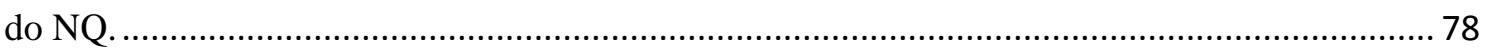

Figura 17 - DTA $(\mu \mathrm{V})$ e TG (\% massa) da amostra de solo LVA................................................ 79

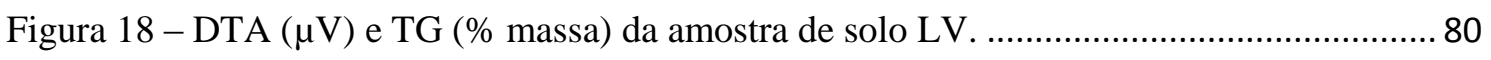

Figura 19 - DTA $(\mu \mathrm{V})$ e TG (\% massa) da amostra de solo NQ............................................. 80

Figura 20 - Frasco 3: Reator com LV sem adição de persulfato; Frasco 5: Reator com LV e com adição de persulfato.

Figura 21 - Decaimento do persulfato nos reatores com concentração inicial de 1g/L. Os pontos representam a média de triplicatas. As linhas contínuas representam resultados calculados por equação de reação de $1^{\mathrm{a}}$ ordem.

Figura 22 - Consumo de persulfato nos reatores com concentração inicial de $14 \mathrm{~g} / \mathrm{L}$. Os pontos representam a média de triplicatas. As linhas contínuas representam resultados calculados por equação de reação de $1^{\mathrm{a}}$ ordem.

Figura 23 - Decaimento da concentração de persulfato após a primeira adição de oxidante e depois da segunda elevação da concentração de oxidante.

Figura 24 - Valores de Eh e pH durante os 15 primeiros dias da oxidação das amostras LVA, LV e NQ com concentração inicial igual a 0, 1 e 14g/L plotadas no Diagrama de Eh-pH para sistema

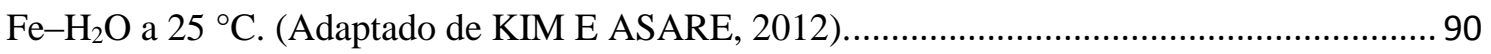

Figura 25 - Porcentagem de grãos que passam pela peneira..................................................... 91

Figura 26: Esquematização da interação do persulfato com o LV .............................................. 98 Figura 27 - Difratogramas do LVA antes e após a oxidação do solo com concentração inicial de

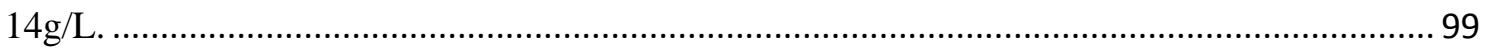

Figura 28 - Difratogramas do NQ antes e após a oxidação do solo com concentração inicial de $14 \mathrm{~g} / \mathrm{L}$. 100 
Figura 29 - Difratogramas do LV antes e após a oxidação do solo com concentração inicial de

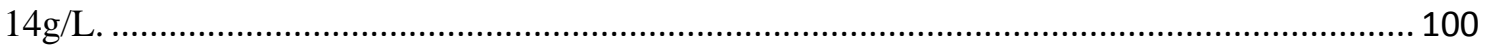

Figura 30 - TG e DTA amostras LVA pré e pós oxidação........................................................ 101

Figura 31 - TG e DTA amostras NQ pré e pós oxidação. ......................................................... 102

Figura 32 - TG e DTA amostras NQ pré e pós oxidação........................................................ 102

Figura 33 - Concentrações relativas de Brometo aferidas na saída da coluna deformada. ........ 104

Figura 34 - Breakthrough brometo - Coluna 1 (Pré oxidação). ............................................... 106

Figura 35 - Breakthrough brometo pré-oxidação Coluna 1, aferido e calculado com modelo Ogata

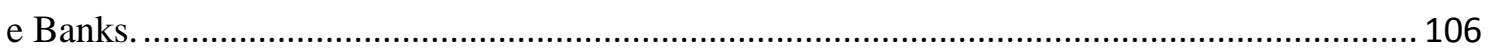

Figura 36 - Breakthrough brometo - Coluna 2 (Pré oxidação). .............................................. 107

Figura 37 - Breakthrough brometo pré-oxidação Coluna 2, aferido e calculado com modelo Ogata

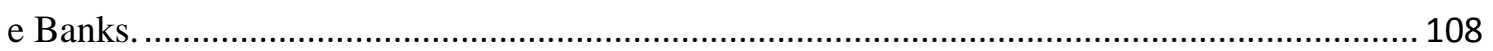

Figura 38 - Curva de Breakthrough de persulfato aferido na Coluna 1................................. 110

Figura 39 - Curva de Breakthrough de persulfato aferido na Coluna 2 .................................. 110

Figura 40 - Variação do pH e Alumínio ao longo do tempo na saída da Coluna 1..................... 112

Figura 41 - Solubilidade da Sílica e da Alumina em função do pH (MASON,1966)............... 113

Figura 42 - Concentração de Ferro II ao longo do tempo Coluna 1 .......................................... 114

Figura 43 - Precipitação de sal a base de ferro (a esquerda) e observação de ferro em solução (a

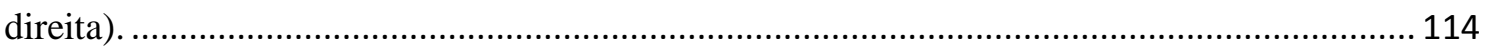

Figura 44 - Variação da condutividade hidráulica ao longo do tempo Coluna 1...................... 115

Figura 45 - Variação da condutividade hidráulica e do pH ao longo do tempo Coluna 1. ....... 116

Figura 46 - Breakthrough brometo - Coluna 1 (Pós oxidação)................................................ 117

Figura 47 - Breakthrough brometo - Coluna 2 (Pós oxidação)................................................. 117

Figura 48 - Coluna 1 pré oxidação na base da coluna (esquerda) fissuras no solo da Coluna 1 pós

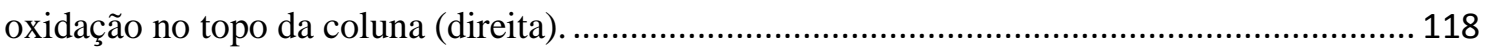

Figura 49 - Coluna 2 pré oxidação na base da coluna (esquerda) fissuras no solo da Coluna 2 pós

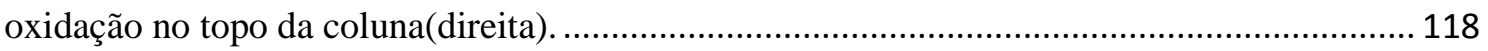

Figura 50 - Breakthrough brometo pós- oxidação na Coluna 1 (ensaio 1), aferido e calculado com

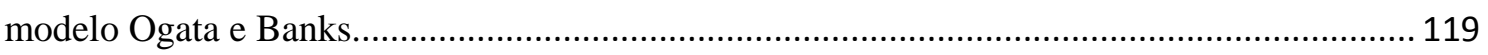

Figura 51 - Breakthrough brometo pós- oxidação na Coluna 1 (ensaio 2), aferido e calculado com

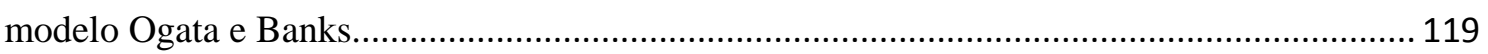

Figura 52 - Breakthrough brometo pós- oxidação na Coluna 2 (ensaio 1), aferido e calculado com

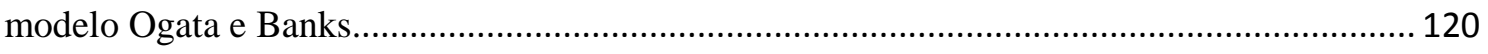

Figura 53 - Breakthrough brometo pós- oxidação na Coluna 2 (ensaio 2), aferido e calculado com

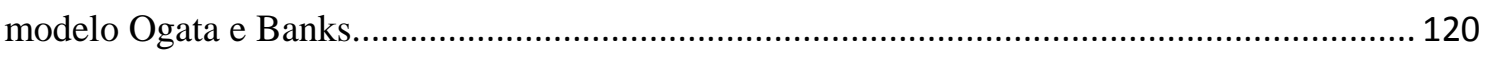

Figura 54 - Breakthrough brometo pós- oxidação na Coluna 2 (ensaio 3), aferido e calculado com modelo Ogata e Banks 120

\section{INDICE DE QUADROS}

Quadro 1: Tendência de oxidação de contaminantes por diferentes oxidantes (USEPA, 2006). 23

Quadro 2: Grupo de Contaminantes oxidados pelo Persulfato (SIEGRIST et. al., 2011)........... 28 


\section{INDICE DE TABELAS}

Tabela 1 - Minerais frequentemente encontrados nos solos e nos aquíferos (WILKIN et al. 2007).

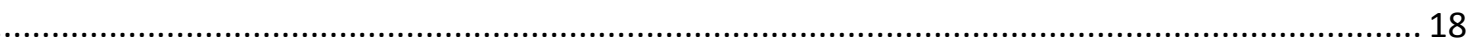

Tabela 2 - Reações com permanganato em função do pH (ITRC, 2005).................................... 26

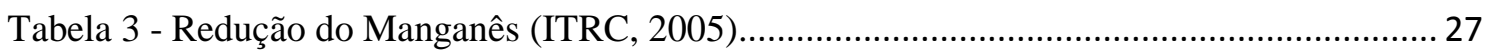

Tabela 4 - Reações com persulfato em função do pH (ITRC, 2005).......................................... 29

Tabela 5 - Semi-reações formadas ao longo da oxidação por persulfato (HUANG, 2002)........ 29

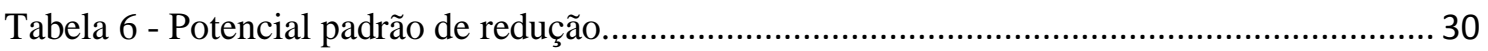

Tabela 7 - Ensaios físico, químicos e mineralógico realizado nas amostras de solo. .................. 40

Tabela 8 - Parâmetros determinados e respectivos métodos analíticos....................................... 41

Tabela 9 - Porcentagem das frações granulométricas nas amostras antes da oxidação. .............. 42

Tabela 10 - Amostras Indeformadas coletadas no Horizonte B do LV para determinação da

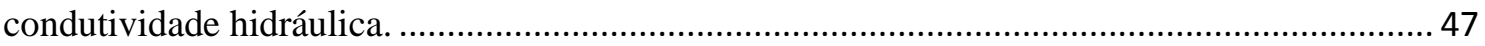

Tabela 11 - Massa de TFSA utilizada para determinação de carbono total. ................................. 50

Tabela 12 - Frações de ferro, soluções extratoras e condições para a extração sequencial......... 51

Tabela 13 - Porcentagem das frações de areia, silte e argila medidos por meio do método de dispersão total e através do método de dispersão natural......................................................... 72

Tabela 14 - Resultados da densidade de partículas das amostras de TFSA dos solos LV, LVA e

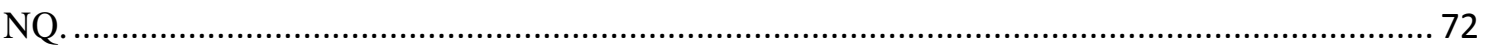

Tabela 15 - Densidade aparente das amostras indeformadas coletadas com anel volumétrico. . 73 Tabela 16 - Resultados da condutividade hidráulica média das 11 amostras indeformada coletadas

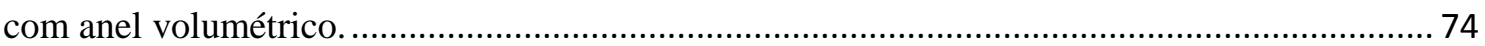

Tabela 17 - Resultados das concentrações de carbono orgânico, cátions, CTC, V, m, pH( $\left.\mathrm{H}_{2} \mathrm{O}\right)$,

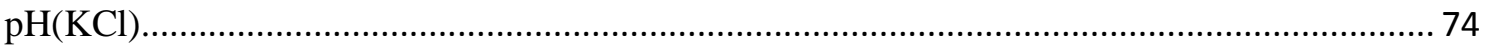

Tabela 18 - Valores de pH de cada um dos solos onde ocorre o ponto de carga zero. ................. 76

Tabela 19 - Concentração de ferro trocável, ligado a matéria orgânica, aos óxidos e concentração

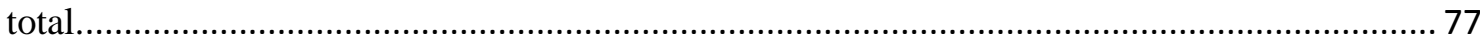

Tabela 20 - Resultados da concentração de caulinita e gibbisita por meio da interpretação da curva TG.

Tabela 21 - Valores das constantes da taxa de reação do decaimento do persulfato nos reatores com concentração inicial de 1 e 14g/L. Desvios padrão (dp) calculados com grau de confiança de $95 \%$.

Tabela 22 - Valores do constante da taxa de reação para os reatores com concentração inicial igual a 1 e 14g/L calculado a partir da normalização da área conforme sugerido por Liu et al. 2014. 86 Tabela 23 - Valores das constantes da taxa de reação do decaimento do persulfato nos reatores com concentração inicial de $1 \mathrm{~g} / \mathrm{L}$ após a $1^{\mathrm{a}}$ adição e a $2^{\mathrm{a}}$ adição de persulfato, desvio padrão (dp), $\mathrm{R}^{2}$ e razão entre as constantes $\mathrm{k}$ da $1^{\mathrm{a}}$ e $2^{\mathrm{a}}$ adição.

Tabela 24 - pH da solução dos reatores antes da adição de oxidante, um e quinze dias após a adição.

Tabela 25 - Variação do potencial de redução (ORP) da solução dos reatores antes da adição de oxidante, um e quinze dias após a adição.

Tabela 26 - Condutividade Hidráulica média da água nas amostras indeformadas antes e após testes preliminares de oxidação.

Tabela 27 - Resultados das concentrações de cátions trocáveis, nas amostras de TFSA do LVA, LV e NQ antes e após a oxidação. 
Tabela 28 - Resultados do potencial hidrogeniônico das amostras de TFSA antes e após a oxidação.

Tabela 29 - Capacidade de Troca Catiônica das amostras deformadas antes e após a oxidação. 95 Tabela 30 - Saturação de base (SB), porcentagem da saturação por base (V) e porcentagem da saturação por alumínio $(\mathrm{m} \%)$ das amostras de solo antes e após a oxidação. .95

Tabela 31 - Concentração de Carbono Orgânico nas amostras pré e pós oxidação. 96

Tabela 32 - Concentração de ferro trocável, ligado a matéria orgânica, aos óxidos e concentração total de ferro nas amostras após a oxidação e variação das concentrações das amostras pré e pós oxidação. 97

Tabela 33 - Concentração de caulinita e gibbisita na fração argilosa das amostras pré e pósoxidação. 101

Tabela 34 - Coeficientes de dispersão obtidos na Coluna 1 e 2 antes e após a oxidação. 121

\section{INDICE DE ANEXOS}

Anexo 1: Descrição Morfológica dos Solos.

Anexo 2: Curvas de Titulação Potenciométricas 


\section{Lista de Abreviaturas}

CI: Carbono Inorgânico.

CO: Carbono Orgânico.

CTC: Capacidade de Troca Catiônica.

DNAPL: Dense Non Aqueous Phase Liquid.

$\mathrm{E}^{0}$ : Potencial padrão de redução.

ISCO: In Situ Chemical Oxidation.

$\mathrm{k}_{\text {obs: }}$ : Constante obtida através do experimento.

$\mathrm{k}_{\text {norm }}$ : Constante da Taxa de Reação Normalizada pela área.

LV: Latossolo Vermelho.

LVA: Latossolo Vermelho Amarelo.

NAPL: Non Aqueous Phase Liquid.

NQ: Neossolo Quartzarênico.

PCZ: Ponto de Carga Zero.

SiBCS: Sistema Brasileiro de Classificação dos Solos.

TFSA: Terra Fina Seca ao Ar. 


\section{RESUMO}

Recentemente, o uso de persulfato em processo de oxidação química in situ em áreas contaminadas por compostos orgânicos ganhou notoriedade. Contudo, a matriz sólida do solo pode interagir com o persulfato, favorecendo a formação de radicais livres, evitando o acesso do oxidante até o contaminante devido a oxidação de compostos reduzidos presentes no solo ou ainda pela alteração das propriedades hidráulicas do solo. Essa pesquisa teve como objetivos avaliar se as interações entre a solução de persulfato com três solos brasileiros poderiam eventualmente interferir sua capacidade de oxidação bem como se a interação entre eles poderia alterar as propriedades hidráulicas do solo. Para isso, foram realizados ensaios de oxidação do Latossolo Vermelho (LV), Latossolo Vermelho Amarelo (LVA) e Neossolo Quartzarênico (NQ) com solução de persulfato ( $1 \mathrm{~g} / \mathrm{L}$ e $14 \mathrm{~g} / \mathrm{L})$ por meio de ensaios de batelada, bem como a oxidação do LV por solução de persulfato $(9 \mathrm{~g} / \mathrm{L}$ e $14 \mathrm{~g} / \mathrm{L})$ em colunas indeformadas.

Os resultados mostraram que o decaimento do persulfato seguiu modelo de primeira ordem e o consumo do oxidante não foi finito. A maior constante da taxa de reação $\left(k_{\text {obs }}\right)$ foi observada para o reator com LV. Essa maior interação foi decorrente da diferença na composição mineralógica e área específica. A caulinita, a gibbsita e os óxidos de ferro apresentaram maior interação com o persulfato. A redução do pH da solução dos reatores causou a lixiviação do alumínio e do ferro devido a dissolução dos minerais.

O ferro mobilizado pode ter participado como catalisador da reação, favorecendo a formação de radicais livres, mas foi o principal responsável pelo consumo do oxidante. Parte do ferro oxidado pode ter sido precipitado como óxido cristalino favorecendo a obstrução dos poros. Devido à maior relação entre massa de persulfato e massa de solo, a constante $\mathrm{k}_{\text {obs }}$ obtida no ensaio com coluna foi 23 vezes maior do que a obtida no ensaio de batelada, mesmo utilizando concentração 1,5 vezes menor no ensaio com coluna. Houve redução na condutividade hidráulica do solo e o fluxo da água mostrou-se heterogêneo após a oxidação devido a mudanças na estrutura dos minerais. Para a remediação de áreas com predomínio de solos tropicais, especialmente do LV, pode ocorrer a formação de radicais livres, mas pode haver um consumo acentuado e não finito do oxidante. Verifica-se que o pH da solução não deve ser inferior a 5 afim de evitar a mobilização de metais para a água subterrânea e eventual obstrução dos poros por meio da desagregação dos grãos de argila.

Palavras-chave: Oxidação química in situ; solos tropicais; remediação. 


\section{ABSTRACT}

Recently the persulfate application for in situ chemical oxidation at areas contaminated by organic compounds gained notoriety. However, the persulfate can interact with the solid matrix of the soil favoring the formation of free radicals, avoiding the oxidant access to the contaminant due to the oxidation of reduced compounds present in the soil or by changing the hydraulic properties of the soil. This research aimed to evaluate if the interactions between the persulfate solutions and three Brazilian tropical soils could eventually interfere on the persulfate oxidation capacity and if the interaction between them could modify the hydraulic properties of the soil. For such, oxidation tests were performed with soils: Latossolo Vermelho (LV), Latossolo Vermelho Amarelo (LVA) and Neossolo Quartzarênico (NQ) with persulfate solution (1 and $14 \mathrm{~g} / \mathrm{L})$ through batch tests and LV oxidation by persulfate solution (9 and $14 \mathrm{~g} / \mathrm{L}$ ) on undisturbed columns.

The results showed that persulfate decay followed a first order model and oxidant consumption was not finite. The higher reaction rate coefficient $\left(\mathrm{k}_{\mathrm{obs}}\right)$ was observed in the reactor with LV. This higher interaction was due to the difference in the mineralogical composition and surface area. Kaolinite, gibbisita and iron oxides showed greater interaction with persulfate. The $\mathrm{pH}$ reduction on the reactor solution caused the aluminum and iron leaching due to dissolution of minerals.

The mobilized iron may have participated as a reaction catalyst favoring the formation of free radicals although it was the major responsible for the oxidant consumption. Part of oxidized iron may have been precipitated as crystalline oxide favoring the clogged pores. As a consequence of the higher mass proportion between persulfate and soil, the $\mathrm{k}_{\text {obs }}$ constant obtained in the column test was 23 times higher than the one observed on the batch test, even utilizing a concentration 1.5 times lower than bath test. There was a reduction in the soil hydraulic conductivity and the water flow proved to be heterogeneous after oxidation due to changes in minerals structure. For remediation purposes in areas with predominance of tropical soils, especially LV, the formation of free radicals may occur but an accented and not finite oxidant consumption may happen. It is verified that the $\mathrm{pH}$ solution should not be inferior than 5 to prevent the mobilization of metals to the groundwater and a possible pores clogging by the breakdown of the clay grains.

Key words: In situ chemical oxidation; tropical soils; remediation. 


\section{INTRODUÇÃO}

Em 1981, a Política Nacional do Meio Ambiente (PNMA), Lei № 6.938/81, com o objetivo de proteger áreas ameaçadas de degradação, recuperar áreas degradadas, controlar as atividades potencialmente poluidoras e outros, instituiu a Avaliação de Impactos Ambientais como instrumento, assim como o licenciamento ambiental e a revisão das atividades efetivas e potencialmente poluidoras (BRASIL, 1981a). Com o objetivo de implantar a Avaliação de Impacto Ambiental como um dos instrumentos da PNMA, o Conselho Nacional do Meio Ambiente estabeleceu os critérios básicos e as diretrizes para a avaliação de impactos ambientais por meio da Resolução $N^{\circ}$ 001/86. Nesta resolução foram citadas diversas atividades consideradas como modificadoras do meio ambiente (BRASIL, 1981b). Posteriormente, a Resolução Conama Nº 237 de 1997 alterou a Resolução 001/86 a fim de aperfeiçoar os critérios utilizados para o licenciamento. Nesta resolução novas atividades e segmentos industriais foram acrescentados como atividade ou empreendimento sujeito ao licenciamento. (BRASIL, 1997).

Somente no ano 2000, as instalações e sistemas de armazenamento de derivados de petróleo e outros combustíveis, ainda não incluídos como atividade passível de licenciamento, foram configurados como empreendimentos potencialmente ou parcialmente poluidores e geradores de acidentes ambientais através da publicação da Resolução Conama N 273/2001 (BRASIL, 2001).

Devido à tardia elaboração e aplicação de instrumentos legais que visassem à prevenção e a recuperação de passivos ambientais, diversas áreas foram contaminadas por substâncias químicas nocivas à saúde humana. Por exemplo, a atividade de posto de combustível, atualmente, está relacionada com $75 \%$ do número de áreas contaminadas no estado de São Paulo (CETESB, 2013). Em dezembro de 2013 havia oficialmente no estado 4.771 áreas contaminadas, 199 áreas a mais em relação ao ano anterior (CETESB, 2012 e CETESB, 2013). Este aumento está relacionado em grande parte ao crescente esforço do órgão ambiental em identificar a existência de passivos ambientais. Deste total, 52\% encontram-se distribuídos entre a cidade de São Paulo e sua Região Metropolitana.

Depois dos postos de combustíveis, a atividade industrial é a responsável pelo maior número de áreas, com 16\% dos casos registrados em dezembro de 2013 no estado de São Paulo (CETESB, 2013). Em relação aos contaminantes presentes nas indústrias, destacam-se os compostos orgânicos voláteis, em especial solventes halogenados que 
correspondem ao quinto composto com maior número de casos de contaminação. Os solventes clorados começaram a ser manipulados no Brasil por volta de 1920, principalmente como desengraxantes de superfícies metálicas, e também tiveram grande utilização na lavagem a seco de produtos têxteis a partir de 1950. As substâncias presentes nesses solventes, em especial os etenos clorados, são extremamente tóxicas e nocivas à saúde humana, sendo que algumas delas oferecem não somente risco toxicológico como também carcinogênico. Segundo a Agência Internacional de Pesquisa em Câncer (IARC) o percloroeteno e o cloreto de vinila são classificados como provável cancerígeno humano (Grupo 2A) e cancerígeno para o ser humano (Grupo 1), respectivamente (CETESB, 2013).

Quando ocorrem vazamentos de compostos orgânicos como combustíveis ou solventes halogenados, as características físico-químicas destes contaminantes e a sua interação com o meio são fatores determinantes para o seu comportamento no ambiente (FETTER, 1994). Devido às propriedades físico-químicas dos contaminantes orgânicos, alguns deles possuem tendência de permanecer em fase separada da água, sendo classificados como NAPL (non-aqueous phase liquid) (FERREIRA, 2003). Os NAPLs acumulam uma grande quantidade da massa de contaminantes e tendem a persistir por longos períodos no aquífero, sendo fontes de contaminação secundárias.

Desta forma, o alvo da remediação de áreas contaminadas deve ser a remoção da fonte secundária de contaminação (NAPL). As técnicas convencionais para sua recuperação dificilmente conseguem remover efetivamente toda a massa de contaminante presente em fase "imiscível", uma vez que parte do produto vazado permanece em fase residual, a qual corresponde a gotas ou agrupamento de gotas isoladas, sem mobilidade no meio poroso (VALENTIN, 2006).

Uma evidência da dificuldade de remediação de áreas contaminadas é o fato de apenas 9\% (425) do total das áreas classificadas como contaminadas encontrarem-se reabilitadas (CETESB, 2013). Um dos motivos para o baixo número de áreas reabilitadas é a deficiência na elaboração do modelo conceitual da área, ou seja, falta de conhecimento a respeito do meio físico onde a contaminação se encontra, da distribuição dos contaminantes e dos processos que afetam o transporte de contaminantes pelo meio. Associado ao baixo grau de conhecimento a respeito da contaminação e do meio, tecnologias inapropriadas e por muitas vezes dispendiosas são aplicadas erroneamente.

Dentre os diversos métodos para remediar áreas contaminadas por solventes e derivados do petróleo, cita-se a Oxidação Química In Situ, cuja aplicação apesar de ainda 
pouco expressiva no estado de São Paulo (3,5\%), mostra-se em ascensão (CETESB, 2013). A oxidação química in situ envolve a introdução de um oxidante químico em subsuperfície a fim de transformar contaminantes presentes no solo ou na água em espécies menos nocivas (USEPA, 2006). Em alguns casos, na América do Norte, foi demonstrado que a técnica funcionou de forma eficiente, já que as metas estipuladas puderam ser atingidas em curto prazo (USEPA, 2006). Além disso, essa técnica minimiza a geração de resíduos e efluentes, pois diferentemente das convencionais, não visa à remoção da contaminação, mas sim a sua transformação.

Oxidantes como peróxido de hidrogênio, peróxido de hidrogênio com aplicação de ferro como catalisador, ozônio, permanganato e persulfato são comumente utilizados para remediação de áreas contaminadas por compostos orgânicos (ITRC, 2005 \& USEPA, 2006 apud YEN et. al., 2011). Dentre os oxidantes citados, a aplicação do persulfato tem se mostrado promissora pelo fato deste oxidante não se decompor rapidamente e não gerar calor suficiente para volatilização dos compostos orgânicos de modo a tornar seu manuseio e aplicação inseguro (TSITONAKI et al, 2010).

O persulfato é o aníon de um sal inorgânico encontrado no estado sólido a temperatura ambiente $\left(\mathrm{Na}_{2} \mathrm{~S}_{2} \mathrm{O}_{8} ; \mathrm{K}_{2} \mathrm{~S}_{2} \mathrm{O}_{8}\right.$ e $\left.\left(\mathrm{NH}_{4}\right) \mathrm{S}_{2} \mathrm{O}_{8}\right)$. O mecanismo de reação do persulfato assemelha-se ao mecanismo de reação do peróxido já que também ocorre formação de radicais livres na presença de catalisadores.

Apesar da crescente aplicação de persulfato para remediação de áreas contaminadas por contaminantes orgânicos, deve-se questionar a viabilidade de sua aplicação, já que além do alvo da contaminação, o oxidante pode interagir com constituintes naturais do solo e alterar algumas características do meio. Isso pode gerar um consumo elevado de oxidante, dificultar o acesso do oxidante ao alvo da contaminação, ou ainda favorecer a mobilização de metais inicialmente presentes na matriz sólida para a água subterrânea. Tendo em vista esta problemática, verifica-se a necessidade de novas pesquisas serem desenvolvidas em relação ao processo de remediação por oxidação química in-situ em solos brasileiros, onde as condições do meio e os constituintes do solo são extremamente diferentes daqueles observados em regiões de clima temperado, onde esta tecnologia e conhecimento da interação dos oxidantes com o meio encontra-se mais difundida e explorada.

No Brasil e em outras regiões são encontrados solos altamente desenvolvidos, cuja composição mineralógica deve-se a processos pedogênicos. Nessa situação, outros constituintes da matriz sólida que são mais reativos (minerais) poderão ter interação 
significativa com o oxidante, além da matéria orgânica. Sendo assim, eventualmente está tecnologia poderá ter sua eficiência aumentada ou eventualmente reduzida caso não seja considerado no projeto de remediação os efeitos da interação do oxidante com o solo.

Com o intuito de aprofundar o entendimento a respeito da remediação por oxidação química de áreas contaminadas por compostos orgânicos, verifica-se a necessidade de se estudar as interações entre o oxidante persulfato e solos tropicais visando aprimorar a eficiência da aplicação desta tecnologia. Ressalta-se que os estudos concernentes a este oxidante ainda foram poucos desenvolvidos, especialmente com solos tropicais.

\section{Objetivos Gerais}

Pretende-se avaliar a interação entre a solução oxidante (persulfato de potássio) e três tipos de solos brasileiros, o transporte do oxidante em um dos três tipos de solo e a aplicabilidade desta tecnologia para áreas com presença dos solos estudados contribuindo assim para projetos de remediação de áreas contaminadas bem como para a compreensão da interação do oxidante em contato com solos brasileiros.

\section{Objetivos Específicos}

- Avaliação da persistência do persulfato em contato com solos;

- Identificação dos constituintes do solo capazes de interagir com o oxidante;

- Avaliar as alterações nas propriedades físicas, químicas e mineralógicas provocadas no solo pela injeção de oxidante e a possibilidade de mobilizar metais para a água;

- Avaliação das alterações nas propriedades hidráulicas em um dos três solos selecionados. 


\section{REVISÃO BIBLIOGRÁFICA}

\subsection{Solos Tropicais Brasileiros}

No final do séc. XVIII, com o avanço da geologia foram empregados métodos geológicos para a classificação dos solos, de modo que sua classificação foi relacionada à rocha de origem, como por exemplo, solos calcários, solos graníticos, solos sedimentares (MEURER, 2010). Na metade do século XIX, o geólogo russo Dokuchaev definiu solo como sendo um corpo natural organizado (MEURER, 2010). Segundo Jenny (1994) todo solo é anisotrópico e possui propriedade vetorial e pode ser tratado como um sistema formado a partir de cinco variáveis: clima, organismos vivos, topografia, material de origem e tempo. Os solos são constituídos basicamente por uma fase líquida, uma fase gasosa e por uma fase sólida. O sistema solo está constantemente em atividade química, onde inúmeras reações se processam ao mesmo tempo dentro de cada uma de suas fases, entre elas e delas com o ambiente. Devido à maior reatividade, a maioria dos fenômenos químicos ocorre nas partículas menores, chamada de fração coloidal (EVANGELOU, 1998).

Os coloides do solo, que compreendem as partículas com diâmetro entre 1 mícron e 1 nanômetro, são compostos principalmente pelas argilas do solo e pela fração mais reativa da matéria orgânica (ácidos húmicos e fúlvicos). A fração coloidal do solo é heterogênea, pois é constituída de diferentes espécies de minerais e materiais orgânicos e, ainda, está no solo em meio a partículas maiores, como silte e areia que também possuem propriedades químicas (EVANGELOU, 1998).

Em regiões tropicais de clima úmido os minerais mais observados são os óxidos, hidróxidos e os filossilicatos (Tabela 1). Os solos tropicais apresentam elevado grau de intemperismo, com mineralogia da fração argila dominada por minerais silicatados do tipo 1:1 (um tetraedro de silício e oxigênio e um octaedro de alumínio e hidroxila) e óxidos de ferro e alumínio (MONIZ, 1975; FONTES \& WEED, 1991; RESENDE, 1995). Os minerais silicatados tipo 1:1 $\left(\mathrm{Al}_{2} \mathrm{Si}_{2} \mathrm{O}_{5}(\mathrm{OH})_{4}\right)$ são formados a partir da hidrólise parcial de feldspatos, a qual remove totalmente o potássio $\left(\mathrm{KAlSi}_{3} \mathrm{O}_{8}\right)$ ou sódio $\left(\mathrm{NaAlSi}_{3} \mathrm{O}_{8}\right)$ ou cálcio $\left(\mathrm{CaAl}_{2} \mathrm{Si}_{2} \mathrm{O}_{8}\right)$ e parcialmente à sílica do mineral. A hidrólise em geral ocorre em ambientes com pH entre 5 e 9, sendo que nesta faixa é possível ocorrer a destruição da estrutura cristalina do mineral e assim haver a liberação dos cátions e ânions os quais podem ser removidos pela drenagem. A intensidade desta atividade depende das condições de renovação das soluções (BERTOLO, 2012). 
Tabela 1 - Minerais frequentemente encontrados nos solos e nos aquíferos (WILKIN et al. 2007).

\begin{tabular}{|c|c|c|}
\hline $\begin{array}{l}\text { Classe de } \\
\text { Minerais }\end{array}$ & \multicolumn{2}{|c|}{ Mineral primário } \\
\hline \multirow{4}{*}{ Hidróxidos } & $\mathrm{Al}(\mathrm{OH})_{3}$ & Gibbsita \\
\hline & $\mathrm{Fe}(\mathrm{OH})_{3}$ & Hidróxido férrico \\
\hline & $\mathrm{FeO}(\mathrm{OH})$ & Goethita \\
\hline & $\mathrm{FeO}(\mathrm{OH})$ & Lepidocrocita \\
\hline \multirow{4}{*}{ Óxidos } & $\mathrm{Fe}_{3} \mathrm{O}_{4}$ & Magnetita \\
\hline & $\mathrm{Fe}_{2} \mathrm{O}_{3}$ & Hematita \\
\hline & $\mathrm{MnO}_{2}$ & Pyrolusita \\
\hline & $\mathrm{SiO} 2$ & Quartzo \\
\hline \multirow{3}{*}{ Carbonatos } & $\mathrm{CaCO}_{3}$ & Calcita \\
\hline & $\mathrm{FeCO}_{3}$ & Siderita \\
\hline & $\mathrm{MnCO}_{3}$ & Rhodocrosita \\
\hline \multirow{2}{*}{ Sulfatos } & $\mathrm{BaSO}_{4}$ & Barita \\
\hline & $\mathrm{CaSO}_{4} .2 \mathrm{H}_{2} \mathrm{O}$ & Gypsum \\
\hline \multirow{2}{*}{ Sulfitos } & $\mathrm{FeS}$ & Mackinawita \\
\hline & $\mathrm{FeS}_{2}$ & Pirita/Marcasita \\
\hline \multirow{2}{*}{ Filossilicatos } & $\mathrm{Al}_{4}(\mathrm{OH})_{8} \mathrm{Si}_{4} \mathrm{O}_{10}$ & Caulinita \\
\hline & $\mathrm{K}_{1,5} \mathrm{Al}_{2}(\mathrm{OH})_{2} \mathrm{Si}_{2,5} \mathrm{Al}_{1,5} \mathrm{O}_{10}$ & Ilita \\
\hline
\end{tabular}

A formação dos óxidos e oxihidróxidos de alumínio e ferro acontece por processos de hidrólise total, ou seja, pela eliminação total dos cátions principais e da sílica. Em geral, este tipo de intemperismo ocorre em ambientes com pluviosidade elevada e boa drenagem (BERTOLO, 2012). Os óxidos de ferro cristalino mais comumente observados são hematita e goethita e estão vinculados a formação de agregados no solo (BERTOLO, 2012). Sua associação com a caulinita e, algumas vezes com a gibbisita em Latossolos brasileiros proporciona uma estrutura em que as partículas de argila estão altamente agregadas, podendo se comportar como partículas de areia (Fontes, 1992).

A gibbisita representa quase que exclusivamente o único óxido de alumínio presente em solos das regiões tropicais e está íntima e diretamente associada à intensidade do intemperismo. Sua presença é muito comum em Latossolos e Argissolos brasileiros (FONTES \& WEED, 1991; MESQUITA FILHO \& TORRENT, 1993; ALLEONI, 1996; NETTO, 1996), e também pode ser encontrada em solos mais jovens, como Cambissolos, devido à possibilidade de vir a ser um dos primeiros produtos formados a partir do intemperismo dos feldspatos. A gibbisita pode reter ânions, principalmente quando encontrada em grandes quantidades no solo (KER, 1995). A gibbisita caracteriza-se por apresentar superfície específica e reatividade em relação à adsorção de ânions bem maiores que a de suas formas cristalinas (BOHN et al., 2001). 
De acordo com o Sistema Brasileiro de Classificação dos Solos (SiBCS), o Latossolo corresponde a uma ordem de solo. O prefixo "Lat" significa muito alterado (EMBRAPA, 2006). Os Latossolos apresentam evolução avançada, com atuação expressiva de processo de latolização (ferralitização ou laterização), resultado da intemperização intensa, com completa ou quase total alteração e decomposição dos minerais primários facilmente intemperizáveis, possui elevada profundidade e baixa capacidade de troca catiônica (CAMARGO et al., 1987). Os Latossolos são solos zonais, sendo que sua ocorrência é comumente pronunciada em zonas tropicais, já que sua formação está principalmente correlacionada a climas com temperaturas e precipitação acentuada (EMBRAPA, 2006).

Os Latossolos apresentam mineralogia da fração argila basicamente dominada por caulinita, gibbisita, goethita e hematita, além de óxidos de ferro e alumínio mal cristalizados (MOURA FILHO, 1970; RESENDE, 1976; MOTCH, 1977; SOUZA, 1979; CURI, 1983; SANTANA; 1984; PALMIERE, 1986; RESENDE ET AL., 1988; KER, 1995; BOGNOLA, 1996 apud KER, 1997). Com base na distribuição espacial das classes de solo no Estado de São Paulo (Figura 1) verifica-se que os Argissolos e Latossolos são predominantes no estado.

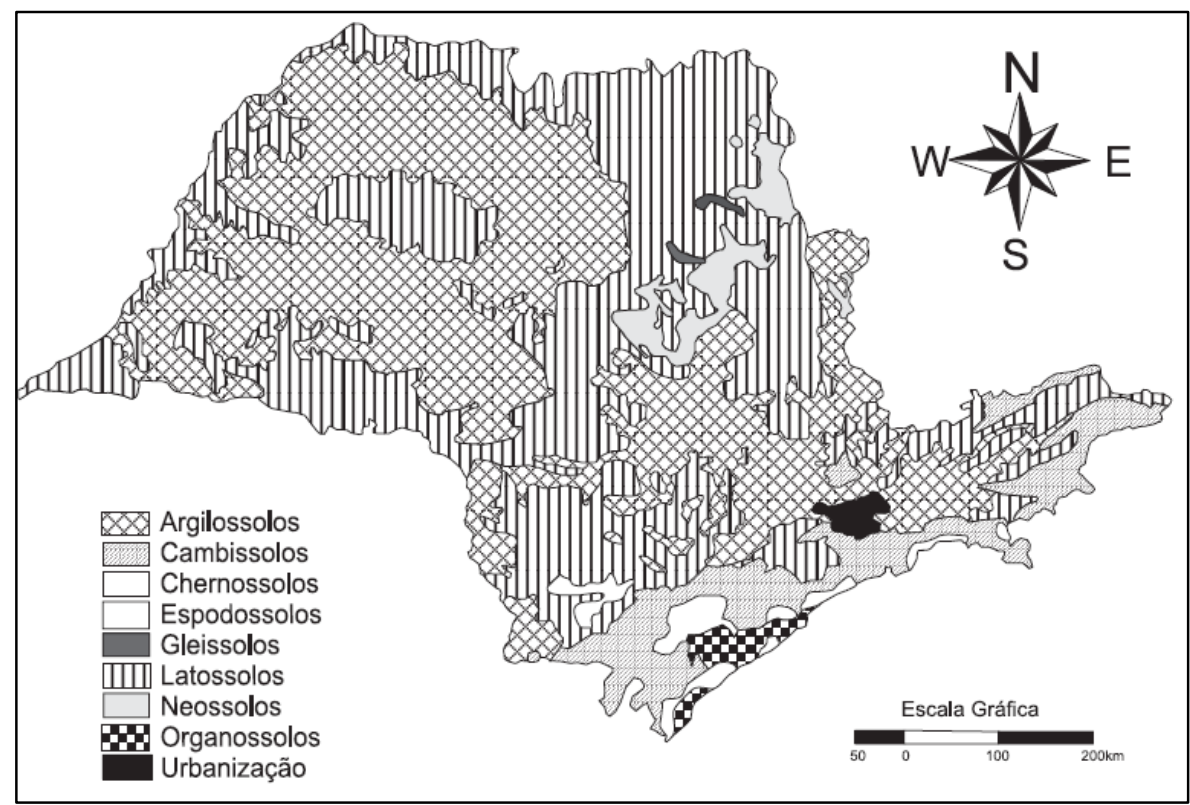

Figura 1 - Mapa Pedológico do estado de São Paulo (OLIVEIRA et al., 1999).

Dentro da ordem do Latossolos destacam-se a subordem Latossolo Vermelho e o Vermelho-Amarelo devido a sua ocorrência (Figura 2 e Figura 3). Estes solos se concentram na Bacia do Paraná. Devido à presença da hematita, o Latossolo Vermelho possui cor avermelhada, enquanto que o Latossolo Vermelho-Amarelo apresenta coloração mais amarelada devido ao predomínio de goethita em relação à hematita. Os 
teores de hematita neste solo variam entre 7 a $11 \%$ quando sua textura é argilosa ou muito argilosa (EMBRAPA, 1988 apud KER, 1997). Conforme apresentado por Ker (1997) o Latossolo Vermelho Amarelo possui a maior distribuição geográfica no Brasil dentre os tipos de Latossolo.
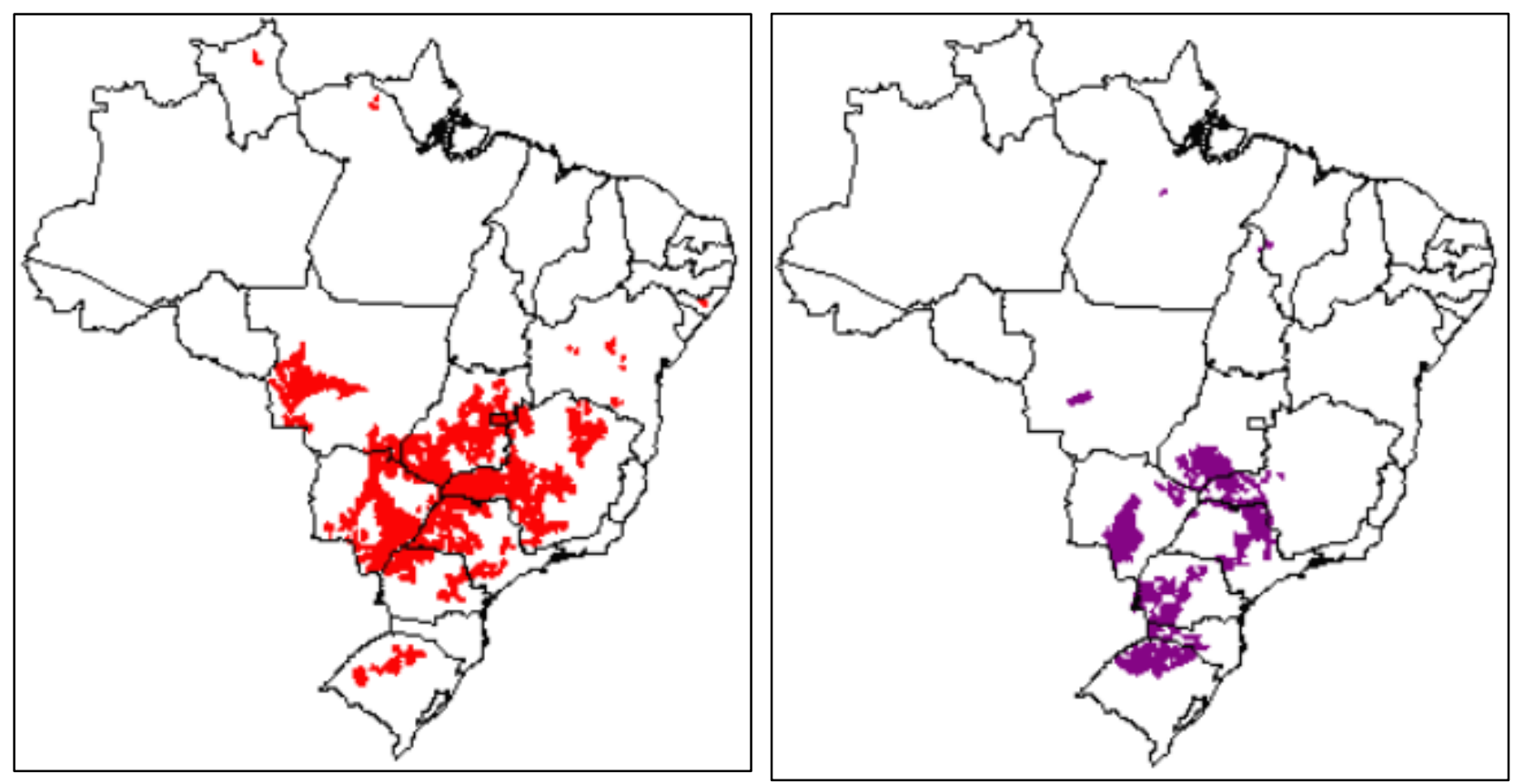

Figura 2 - Ocorrência do Latossolo Vermelho Não Férrico (esquerda) e Férrico (direita) (UFL, 2014a e UFL, 2014b).

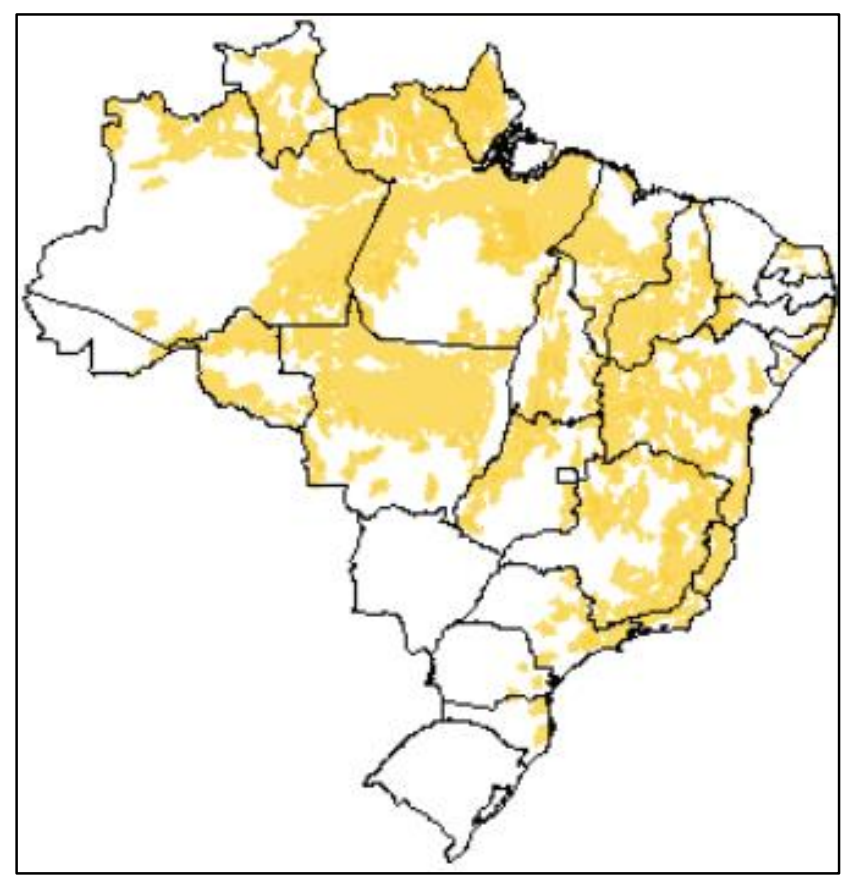

Figura 3 - Ocorrência do Latossolo Vermelho Amarelo no Brasil (UFL, 2014c). 
De acordo com a base de dados da Embrapa (2014) a classe dos Latossolos possui a maior distribuição no território brasileiro com $31,5 \%$ de ocupação com aproximadamente $2.681 .600 \mathrm{~km}^{2}$. Por outro lado, dos solos com menor ocorrência no Brasil, destaca-se a classe dos Neossolos, sendo que dentre os Neossolos está o Neossolo Quartzarênico cuja formação está relacionada principalmente ao material de origem (arenitos).

De acordo com a Embrapa (2006), esta classe trata-se de solos poucos evoluídos, formado por material mineral ou orgânico com ausência de horizonte diagnóstico (Horizonte B) o qual é responsável pela classificação do solo. A subordem Neossolo Quartzarênico é caracterizada por apresentar textura arenosa ou areia franca em todos os horizontes até pelo menos $1,5 \mathrm{~m}$ de profundidade, são solos quartzosos, sendo a fração arenosa composta por no mínimo 95\% de quartzo e com ausência de minerais primários alteráveis (minerais menos resistentes ao intemperismo) (EMBRAPA, 2006).

\subsection{Remediação por Oxidação Química In Situ}

A oxidação química tem sido estudada e utilizada em diversas áreas vinculadas à engenharia química e tratamento de efluentes e águas superficiais. Em relação aos ambientes subterrâneos, esta tecnologia tem sido aplicada in situ para o tratamento de águas contaminadas especialmente por compostos orgânicos clorados e hidrocarbonetos derivados do petróleo. A aplicação de oxidante in situ pode ocorrer de três formas diferentes, sendo uma através da injeção da solução oxidante em poços de injeção, outra por meio da mistura do oxidante no solo com auxílio de retroescavadeira e a terceira seria a injeção do oxidante na profundidade do solo desejada a partir da utilização de sondas de percussão hidráulicas do tipo direct push, equipamento capaz de empurrar ou conduzir haste de aço até a profundidade desejada (USEPA, 2011), fazer a injeção e em seguida remover o equipamento daquele ponto. Normalmente a técnica de remediação por oxidação química in situ é aplicada junto a outras como, por exemplo, atenuação natural monitorada (USEPA, 2006).

O objetivo da aplicação da metodologia de oxidação para remediação de áreas contaminadas por compostos orgânicos é transformar espécies ofensivas à saúde humana em espécies menos tóxicas ou inofensivas a saúde por meio da oxidação completa ou parcial do contaminante. Desta forma, o processo de oxidação pode envolver desde a adição de oxigênio, a remoção de hidrogênio e/ ou a retirada de elétrons com ou sem a retirada de $\mathrm{H}^{+}$(USEPA, 2006). 
Para compreender o processo de oxidação devem ser diferenciados os dois tipos básicos desta reação, sendo elas: oxidação direta onde há transferência direta de elétrons entre as espécies; e oxidação indireta, com formação de radicais livres.

$\mathrm{Na}$ oxidação direta, a reação química é menos complexa, mais previsível e possui menor potencial de oxidação quando comparada com aquela por formação de radicais livres (indireta) (SIEGRIST et. al., 2011).

A formação de radicais é o resultado da reação entre o oxidante e alguma espécie de catalisador. Nesta reação ocorrem reações de segunda ordem onde são formadas espécies intermediárias. Além da necessidade de haver um catalisador, as condições físico-químicas da solução como temperatura, $\mathrm{pH}$, salinidade devem ser favoráveis, sendo que as condições favoráveis irão variar entre os tipos de oxidante e de contaminantes envolvidos (SIEGRIST et. al., 2011). O radical formado possui maior potencial padrão de redução (EBERSON, 1987 apud LIANG et al., 2008) o que é favorável para a oxidação do contaminante.

O custo médio da remediação por oxidação química in situ na América do Norte encontra-se na ordem de $\$ 100 / \mathrm{m}^{3}$ de solo tratado. Contudo, o custo pode ter variações elevadas dependendo das características do contaminante bem como do meio e do oxidante utilizado (SIEGRIST et. al., 2011).

Em condições adequadas, várias espécies de oxidantes podem transformar e mineralizar compostos orgânicos, dentre eles os hidrocarbonetos derivados do petróleo (SIEGRIST et. al., 2011). As espécies químicas utilizadas usualmente para fins de oxidação química por serem capazes de oxidar o contaminante orgânico durante o processo de transferência de elétrons são: peróxido de hidrogênio, reagente fenton, permanganato, persulfato, ozônio (Quadro 1) e outras. A definição do oxidante a ser empregado no processo de remediação pode variar de acordo com as características dos contaminantes, do meio, além de custos, logística de cada projeto de remediação. 
Quadro 1: Tendência de oxidação de contaminantes por diferentes oxidantes (USEPA, 2006)

\begin{tabular}{|c|c|c|c|c|c|c|c|c|c|c|c|c|c|c|c|c|c|}
\hline \multirow{2}{*}{ Contaminante } & \multicolumn{4}{|c|}{ MnO4- } & \multicolumn{5}{|c|}{ Fenton $\left(\mathrm{H}_{2} \mathrm{O}_{2} / \mathrm{Fe}\right)$} & \multirow{2}{*}{$\begin{array}{c}\mathrm{S}_{2} \mathrm{O}_{8}{ }^{2-} \\
(1) \\
\mathrm{a}\end{array}$} & \multicolumn{3}{|c|}{$\mathrm{SO}_{4}^{-\bullet}(1)$} & \multicolumn{4}{|c|}{ Ozônio } \\
\hline & $\mathrm{a}$ & $\mathrm{b}$ & $\mathrm{c}$ & $d$ & a & $\mathrm{b}$ & $\mathrm{c}$ & d & $\mathrm{e}$ & & $\mathrm{a}$ & $\mathrm{b}$ & $c^{2}$ & $\mathrm{a}$ & $\mathrm{b}$ & $\mathrm{c}$ & $\mathrm{d}$ \\
\hline $\begin{array}{c}\text { Hidrocarbonetos } \\
\text { de Petróleo }\end{array}$ & $\mathrm{B}^{2}$ & & & & $\mathrm{E}^{2}$ & & & & & $\mathrm{~B} / \mathrm{E}^{2}$ & $\mathrm{E}^{2}$ & & & $\mathrm{E}^{2}$ & & & \\
\hline BTEX & & $E^{2}$ & $E^{2}$ & $\mathrm{E}$ & & $\mathrm{E}$ & $E^{2}$ & $\mathrm{E}$ & $\mathrm{E}$ & & & $\mathrm{E}$ & $E^{2}$ & & $\mathrm{E}$ & $\mathrm{B}^{2}$ & $\mathrm{E}$ \\
\hline Benzeno & $\mathrm{P}^{2}$ & $\mathrm{~B}^{2}$ & $\mathrm{P}^{2}$ & & $\mathrm{E}^{4}$ & & $E^{2}$ & & $\mathrm{E}$ & $\mathrm{B}^{2}$ & $\mathrm{~B} / \mathrm{E}^{2}$ & & $\mathrm{E}$ & $E^{2}$ & & $\mathrm{~B}^{2}$ & \\
\hline Fenol & B & $\mathrm{E}$ & $\mathrm{E}$ & & $\mathrm{E}$ & $\mathrm{E}$ & $\mathrm{E}$ & $\mathrm{E}$ & $\mathrm{E}$ & $\mathrm{P} / \mathrm{B}$ & $\mathrm{B} / \mathrm{E}$ & $\mathrm{E}$ & $\mathrm{E}$ & & $\mathrm{E}$ & $\mathrm{E}$ & $\mathrm{E}$ \\
\hline PAH & B & $\mathrm{E}$ & $\mathrm{E}$ & $\mathrm{E}$ & $\mathrm{E}$ & B & B & $\mathrm{E}$ & $\mathrm{E}$ & $\mathrm{B}$ & $\mathrm{E}$ & B & $\mathrm{B} / \mathrm{E}$ & $\mathrm{E}$ & $\mathrm{B}$ & $\mathrm{E}$ & $\mathrm{E}$ \\
\hline MTBE & $\mathrm{B}$ & & & & $\mathrm{B}$ & $\mathrm{E}$ & & & $\mathrm{E}$ & $\mathrm{P} / \mathrm{B}$ & $E$ & $\mathrm{E}$ & & B & $\mathrm{E}$ & & \\
\hline $\begin{array}{c}\text { Álcool } \\
\text { terc-Butílico }\end{array}$ & & & & & & $\mathrm{E}$ & & & B & & & $\mathrm{E}$ & & & $\mathrm{E}$ & & \\
\hline $\begin{array}{c}\text { Etenos } \\
\text { Clorados }\end{array}$ & $\mathrm{E}$ & $\mathrm{E}$ & $\mathrm{E}$ & $\mathrm{E}$ & $\mathrm{E}$ & $\mathrm{E}$ & $\mathrm{E}$ & $\mathrm{E}$ & $\mathrm{E}$ & B & $\mathrm{E}$ & $\mathrm{E}$ & $\mathrm{E}$ & $\mathrm{E}$ & $\mathrm{E}$ & & $\mathrm{E}$ \\
\hline $\begin{array}{l}\text { Tetracloreto } \\
\text { de Carbono }\end{array}$ & $\mathrm{P}$ & $\mathrm{P}$ & $\mathrm{P}$ & & $\mathrm{P} / \mathrm{B}$ & B & $\mathrm{P}$ & & $\mathrm{P}$ & $\mathrm{P}$ & $\mathrm{P} / \mathrm{B}$ & & $\mathrm{P} / \mathrm{E}$ & $\mathrm{P} / \mathrm{B}$ & $\mathrm{P}$ & & \\
\hline Clorofórmio & & $\mathrm{P}$ & $\mathrm{P}$ & & & $\mathrm{P}$ & $\mathrm{P}$ & & $\mathrm{P}$ & & & & $\mathrm{B} / \mathrm{E}$ & & $\mathrm{P}$ & & \\
\hline $\begin{array}{c}\text { Cloreto de } \\
\text { Metileno }\end{array}$ & & & $\mathrm{P}$ & & & B & B & & $\mathrm{P}$ & & & & $\mathrm{B} / \mathrm{E}$ & & B & & \\
\hline $\begin{array}{c}\text { Etanos } \\
\text { Clorados }^{2}\end{array}$ & $\mathrm{P}$ & & & $\mathrm{P}$ & $\mathrm{B} / \mathrm{E}$ & & & $\mathrm{P}$ & $\mathrm{P}$ & $\mathrm{P}$ & $\mathrm{B} / \mathrm{E}$ & & & B & & & $\mathrm{P}$ \\
\hline Tricloroetano $^{2}$ & & $\mathrm{P}$ & $\mathrm{P}$ & & & $\mathrm{E}$ & $\mathrm{P}$ & & $\mathrm{P}$ & & & & $\mathrm{P} / \mathrm{E}$ & & $\mathrm{P}$ & & \\
\hline Dicloroetano $^{2}$ & & & $\mathrm{P}$ & & & B & B & & $\mathrm{P}$ & & & & $\mathrm{B} / \mathrm{E}$ & & B & & \\
\hline Clorobenzeno & & & $\mathrm{P}$ & & & $\mathrm{E}$ & $\mathrm{E}$ & & $\mathrm{E}$ & & & $\mathrm{E}$ & $\mathrm{E}$ & & $\mathrm{E}$ & & \\
\hline PCB & $\mathrm{P}$ & $\mathrm{P}$ & $\mathrm{P}$ & $\mathrm{P}$ & $\mathrm{P}$ & B & $\mathrm{P}$ & $\mathrm{P}$ & $\mathrm{E}$ & $\mathrm{P}$ & $\mathrm{P}$ & $\mathrm{P}$ & $\mathrm{P} / \mathrm{E}$ & & $\mathrm{P}$ & $\mathrm{E}$ & $\mathrm{P}$ \\
\hline $\begin{array}{l}\text { Nitroamina } \\
\text { RDX, HMX }\end{array}$ & $\mathrm{E}$ & & & & $\mathrm{E}$ & & & & & $\mathrm{B}$ & $\mathrm{E}$ & & & $\mathrm{E}$ & & & \\
\hline Explosivos & & $\mathrm{E}$ & $\mathrm{E}$ & & & $\mathrm{E}$ & B & & & & & B & $\mathrm{B} / \mathrm{E}$ & & $\mathrm{E}$ & $\mathrm{E}$ & \\
\hline Pesticidas & & $\mathrm{B}$ & $\mathrm{B}$ & & & $\mathrm{P}$ & $\mathrm{P}$ & & $\mathrm{B} / \mathrm{E}^{3}$ & & & B & $\mathrm{B} / \mathrm{E}$ & & $\mathrm{P}$ & $E$ & \\
\hline 1,4-Dioxano 4 & & & & & & $\mathrm{E}$ & & & $\mathrm{E}$ & & & $\mathrm{E}$ & & & & & \\
\hline
\end{tabular}

Nota: as diferentes fontes utilizaram diferentes terminologias:

a; e - P: pobre, B: bom, E: excelente; b - P: recalcitrante, B: relutante, E: tratável; c - P: recalcitrante (reatividade baixa ou não reativo), B: relutante (reatividade média), E: tratável (reatividade alta); d-P: difícil tratamento, E: suscetível. Fontes:

a - SPERRY e COOKSON, 2002 apud USEPA, 2006; b - ITRC, 2005 apud USEPA, 2006; c - BROWN, 2003 apud USEPA, 2006; d - SIEGRIST et. al., 2001 apud USEPA, 2006; e - BRUXTON et. al., 1988 e HAAG e YAO, 1992 apud USEPA, 2006; 1 - FMC, 2005 apud USEPA, 2006; 2 - USEPA, 2006; 3 - HAAG e YAO, 1992 apud USEPA, 2006; 4 - BROWN et. al. 2004 apud USEPA, 2006.

\subsection{Desafios para a Oxidação Química In Situ}

A oxidação química in situ, também conhecida como ISCO (in situ chemical oxidation) pode ter sua eficiência afetada por diversos fatores, como o transporte do oxidante e/ ou contaminante em subsuperfície, dimensões da área fonte, transferência de massa, cinética de reação e a demanda natural de oxidante (SIEGRIST et. al., 2011). Estes fatores devem ser considerados a fim de avaliar a viabilidade da aplicação do método, garantir sua eficiência e minimizar os custos operacionais da remediação. 
Em geral, em projetos realizados na América do Norte são realizados dois a três eventos de aplicação de oxidante ao solo para atingir as metas de remediação. Contudo, em alguns casos as concentrações dos contaminantes podem aumentar após a interrupção da injeção de oxidante (processo chamado de rebound), devido a uma série de processos, como a dessorção e difusão a partir de camadas menos permeáveis bem como devido à presença de contaminante na forma de saturação residual. (COHEN, 1997).

Além disso, a interação natural do oxidante com o meio é um fator que ainda tem dificultado o dimensionamento do projeto de remediação através da ISCO. Para que a oxidação possa ocorrer efetivamente é necessário que o oxidante entre em contato com o contaminante orgânico. Desta forma o processo de transporte da solução oxidante também controla a eficiência desta metodologia de remediação. Estudos apontam a obstrução de poros devido a reação entre o oxidante (permanganato) e os compostos alvos especialmente na área fonte, local com acúmulo de fase imiscível (SIEGRIST et. al., 2011).

Para avaliar o melhor oxidante a ser utilizado deve-se inicialmente considerar o contaminante a ser oxidado já que a reação dos oxidantes varia de acordo com o contaminante. Para os derivados de petróleo, os autores Yen et al. (2011) verificaram que entre o permanganato, o persulfato e o peróxido de hidrogênio os que apresentaram melhor potencial padrão de redução na remoção de óleo diesel era o permanganato seguido pelo persulfato e peróxido de hidrogênio.

Contudo, os radicais livres de sulfato possuem um potencial padrão de redução maior do que o do permanganato, aumentando sua eficiência na transformação dos contaminantes. Logo, favorecendo a formação de radicais sulfato, a partir da catalisação, a oxidação de derivados de petróleo seria mais eficiente a partir da utilização do persulfato ao invés do permanganato (YEN et al., 2011).

Alguns contaminantes recalcitrantes podem ser oxidados apenas com oxidantes fortes, por outro lado oxidantes mais fortes podem ser consumidos mais rapidamente em subsuperfície, limitando seu deslocamento pelo aquífero. Oxidantes menos reativos são mais estáveis e podem ser transportados por distâncias maiores no subsolo. Para fins de remediação in situ, o permanganato e o persulfato são mais persistentes se comparados ao peróxido de hidrogênio. O peróxido de hidrogênio não se mostra eficiente, pois apesar de apresentar um melhor potencial padrão de redução, este oxidante não é capaz de permanecer por longo período no meio devido a sua fácil decomposição (ITRC, 2005 apud YEN et al. 2011; FERRARESE, 2008). Além disso, as reações deste oxidante com 
compostos orgânicos são exotérmicas o que não é aconselhável quando se trata de um tratamento em subsuperfície onde se tem maior dificuldade em controlar as condições do meio.

\subsection{Principais Oxidantes}

\subsubsection{Peróxido de hidrogênio}

A utilização do peróxido para tratamento de efluentes é eficiente em vista das propriedades deste oxidante como, por exemplo, transparência, odor característico, miscibilidade em água, cinética de reação elevada e, não ser considerado inflamável, apesar de, se misturado com substâncias orgânicas a determinadas concentrações, pode resultar em um componente explosivo perigoso (MATTOS et al., 2003).

Pardieck et al. (1992) citou também a grande escala de uso de peróxido para tratamento de efluente industrial e citou a tendência da crescente aplicação desta tecnologia em projetos relacionados ao tratamento in situ de áreas contaminadas, a qual estaria em segundo lugar na utilização deste produto, logo após a indústria de papel e celulose onde o peróxido é utilizado para branqueamento do papel.

A primeira aplicação de peróxido para remediação de águas subterrâneas contaminadas ocorreu em 1980 quando a decomposição do peróxido de hidrogênio em água e oxigênio foi termodinamicamente considerada favorável, passando a ser então reconhecida como uma potencial fonte de liberação de oxigênio favorecendo o processo de biodegradação (PARDIECK et al., 1992). Em meados de 1990, o peróxido foi aplicado no solo juntamente com a aplicação de catalisadores para fins de oxidação química in situ (SIEGRIST et. al., 2011).

Em 1894, Henry J. Fenton verificou que o peróxido poderia ser ativado por sais de ferro bivalente para oxidar ácido tartárico, surgindo assim o nome do produto Fenton. Pignatello et al. (2006) apresentaram revisão crítica sobre a utilização do Fenton como oxidante a ser aplicado para descontaminação de águas subterrâneas. Umas das limitações da utilização do Fenton em tratamento de efluentes em escala industrial citada por Pignatello et al., (2006) foi em relação à elevada geração de lodo, a necessidade de controlar o pH devido a tendência de acidificação da água, a instabilidade do reagente e a perda de produto devido à perda de capacidade de catálise para produção de oxigênio e água, além de interferência de substâncias que complexam os íons de ferro e a formação de lodos com excesso de ferro. 


\subsubsection{Permanganato}

$\mathrm{O}$ permanganato $\left(\mathrm{MnO}_{4}^{-}\right)$é a forma em que o manganês encontra-se em maior estado de oxidação (7+) o que lhe confere capacidade em atuar como agente oxidante podendo assim ser reduzido até seu menor estado de oxidação (4+). Sabe-se que íons de permanganato são capazes de oxidar ligações duplas de cadeias de alcenos (WOLFE \& INGOLD, 1981; WALTON et al., 1992, apud BROWN et al., 2003).

Existem duas formas comuns de permanganato utilizadas em projetos de remediação, permanganato de potássio $\left(\mathrm{KMnO}_{4}\right)$ e de sódio $\left(\mathrm{NaMnO}_{4}\right)$. O $\mathrm{KMnO}_{4}$ é um sólido cristalino o qual pode ser misturado na forma sólida. Já o $\mathrm{NaMnO}_{4}$ é geralmente fornecido como um líquido concentrado (40\%), mas é geralmente aplicado mais diluído. O sal formado com o sódio ao invés do potássio pode ser considerado mais perigoso por se encontrar no estado líquido e por ser mais reativo e exotérmico. Este oxidante é eficaz apenas para compostos orgânicos que contêm ligações duplas entre carbonos, grupos aldeído, ou grupos hidroxila (ITRC, 2005).

Bragato e Tenório (2007) compararam a oxidação de benzeno através de permanganato e peróxido. Neste estudo os autores avaliaram a influência da correção do pH na eficiência da oxidação. A oxidação por permanganato tende a ocorrer em meios alcalinos enquanto que por peróxido em $\mathrm{pH}$ ligeiramente ácido $(\sim 4,0)$. Contudo, nos resultados obtidos os autores revelaram que não houve diferença significativa na degradação de benzeno tanto por peróxido quanto por permanganato em sistemas com $\mathrm{pH}$ equivalente a 5,6 e 8,0. A seguir são apresentadas as reações envolvendo o permanganato em meio com diferentes valores de $\mathrm{pH}$.

Tabela 2 - Reações com permanganato em função do pH (ITRC, 2005).

\begin{tabular}{cc}
\hline Solução & Reação \\
\hline Ácida $\mathrm{pH}<3,5$ & $\mathrm{MnO}_{4}{ }^{-}+8 \mathrm{H}^{+}+5 \mathrm{e}^{-} \rightarrow \mathrm{Mn}^{2+}+4 \mathrm{H}_{2} \mathrm{O}$ \\
\hline $3,5<\mathrm{pH}<12$ & $\mathrm{MnO}_{4}{ }^{-}+2 \mathrm{H}_{2} \mathrm{O}+3 \mathrm{e}^{-} \rightarrow \mathbf{M n O}_{2}(\mathbf{s})+4 \mathrm{OH}^{-}$ \\
\hline Alcalina $(\mathrm{pH}>12)$ & $\mathrm{MnO}_{4}{ }^{-}+\mathrm{e}^{-} \rightarrow \mathrm{MnO}_{4}{ }^{2-}$ \\
\hline
\end{tabular}

Nas reações listadas na Tabela 2, o manganês parte do estado de oxidação +7 para $+2,+4$ e +6, na solução com $\mathrm{pH}$ menor que 3,5; entre 3,5 e 12 e maior que 12, respectivamente. Na condição natural mais próxima dos aquíferos ( $\mathrm{pH}$ entre 3,5 e 12) é verificada a formação de precipitado de óxido de manganês. O excesso de $\mathrm{Mn}^{2+}$ formado em condições de acidez elevada poderá ser oxidado formando também precipitado. 
Contudo este precipitado poderá naturalmente retornar ao seu estado inicial a partir da redução conforme indicado na tabela abaixo.

Tabela 3 - Redução do Manganês (ITRC, 2005).

\begin{tabular}{c}
\hline $3 \mathrm{MnO}_{2}+2 \mathrm{MnO}_{4^{-}}+2 \mathrm{H}_{2} \mathrm{O} \rightarrow 5 \mathrm{MnO}_{2}(\mathrm{~s})+4 \mathrm{H}^{+}$ \\
$\mathrm{MnO}_{2}(\mathrm{~s})+4 \mathrm{H}^{+}+2^{\mathrm{e}-} \rightarrow \mathrm{Mn}^{2+}+2 \mathrm{H}_{2} \mathrm{O}$ \\
\hline
\end{tabular}

\subsubsection{Persulfato}

O persulfato pode ser encontrado na forma de sais como persulfato de amônio $\left(\mathrm{NH}_{4} \mathrm{~S}_{2} \mathrm{O}_{8}\right)$, persulfato de sódio $\left(\mathrm{Na}_{2} \mathrm{~S}_{2} \mathrm{O}_{8}\right)$ e persulfato de potássio $\left(\mathrm{K}_{2} \mathrm{~S}_{2} \mathrm{O}_{8}\right)$. A utilização de persulfato de amônio não é vantajosa devido à geração de amônia em água subterrânea. A solubilidade do persulfato de amônio, de sódio e de potássio são respectivamente: $817 \mathrm{~g} / \mathrm{L}$ a $25^{\circ} \mathrm{C}, 545$ e $620 \mathrm{~g} / \mathrm{L}$ a $20^{\circ} \mathrm{C}$.

O uso de persulfato para remediação por oxidação química é mais recente do que os demais citados. $\mathrm{O}$ sal de persulfato em água dissocia-se no aníon $\left(\mathrm{S}_{2} \mathrm{O}_{8}{ }^{2-}\right)$ o qual possui elevado potencial padrão de redução e possui uma cinética lenta na destruição de diversos contaminantes orgânicos. A oxidação química de contaminantes orgânicos por persulfato geralmente ocorre com auxílio de fonte externa de energia a qual pode ser decorrente de calor, foto-catálise, ou catálise metálica (RODRIGUES, 2006). Espécies altamente reativas como o radical sulfato $\left(\mathrm{SO}_{4}{ }^{-{ }^{-}}\right)$e o radical hidroxila $\left(\mathrm{OH}^{*}\right)$ são gerados a partir de foto-catálise ou decomposição térmica dos íons persulfato em fase aquosa (WILMARTH AND HAIM,1962; NOSOV,1966; DOGLIOTTI \& HAYON,1967; HAYON \& MCGARVEY,1967; BERLIN,1986; TANNER \& OSMAN,1987 apud HUANG et al., 2002). Diversos grupos de contaminantes podem ser oxidados pelo persulfato, sendo que alguns dependem da formação de radicais livres (Quadro 1 e 2). 
Quadro 2: Grupo de Contaminantes oxidados pelo Persulfato (SIEGRIST et. al., 2011).

\begin{tabular}{|c|c|c|}
\hline $\begin{array}{c}\text { Grupo de } \\
\text { Contaminante }\end{array}$ & $\begin{array}{l}\text { Suscetibilidade de oxidação } \\
\text { pelo persulfato }\end{array}$ & Observações \\
\hline $\begin{array}{l}\text { Alifáticos } \\
\text { halogenados }\end{array}$ & $\begin{array}{l}\text { Sim, dependente do tipo de } \\
\text { contaminante }\end{array}$ & $\begin{array}{l}\text { Cloroetenos altamente propício; } \\
\text { Cloroetanos menos propício; } \\
\text { Clorometanos propício apenas em } \\
\text { condições com ativação intensa. }\end{array}$ \\
\hline $\begin{array}{l}\text { Compostos } \\
\text { aromáticos } \\
\text { clorados }\end{array}$ & $\begin{array}{l}\text { Sim, dados limitados, mas } \\
\text { alta probabilidade }\end{array}$ & $\begin{array}{l}\text { Poucos dados publicados, mas existem } \\
\text { dados que indicam alta suscetibilidade para } \\
\text { a maioria dos compostos aromáticos } \\
\text { clorados; A oxidação de compostos } \\
\text { aromáticos com estrutura mais complexas } \\
\text { possuem elevada dependência da ativação }\end{array}$ \\
\hline $\begin{array}{l}\text { Hidrocarbonetos } \\
\text { de combustíveis }\end{array}$ & $\begin{array}{l}\text { Sim, dependente da ativação } \\
\text { do persulfato }\end{array}$ & $\begin{array}{c}\text { A oxidação de compostos aromáticos com } \\
\text { estrutura mais complexas possuem elevada } \\
\text { dependência da ativação }\end{array}$ \\
\hline $\begin{array}{l}\text { Hidrocarbonetos } \\
\text { policíclicos } \\
\text { aromáticos }\end{array}$ & $\begin{array}{l}\text { Sim, dependente da ativação } \\
\text { do persulfato }\end{array}$ & $\begin{array}{l}\text { A oxidação de compostos aromáticos com } \\
\text { estrutura mais complexas possuem elevada } \\
\text { dependência da ativação, pouca } \\
\text { informação disponível sobre a } \\
\text { suscetibilidade de componentes individuais }\end{array}$ \\
\hline $\begin{array}{l}\text { Compostos } \\
\text { orgânicos } \\
\text { nitrogenados }\end{array}$ & $\begin{array}{l}\text { Sim, alguns são mais } \\
\text { passíveis do que outros. }\end{array}$ & $\begin{array}{l}\text { 2,4,6-Trinitrotolueno (TNT) aparenta ser } \\
\text { mais suscetível do que Dinitrotolueno } \\
\text { (DNT); dados limitados }\end{array}$ \\
\hline Pesticidas & Possível & $\begin{array}{c}\text { Dados limitados; aparenta depender } \\
\text { complexidade da estrutura e da ativação }\end{array}$ \\
\hline
\end{tabular}

Pesquisas recentes mostram que a persistência do persulfato é diferente daquela observada para o permanganato e apresenta certa similaridade no comportamento da decomposição do peróxido pelo fato de a depleção do persulfato ser impactada pela ocorrência de minerais catalíticos (SRA et al., 2007, 2010, apud SIEGRIST et. al., 2011). Em meios onde os minerais catalíticos não são alterados ou esgotados, a depleção do persulfato eventualmente poderá ser total (SIEGRIST et. al., 2011) comprometendo assim a oxidação do alvo da remediação.

Assim como o permanganato, conforme ilustrado na Tabela 4, as reações de degradação do persulfato poderão variar de acordo com o pH (ITRC, 2005). 
Tabela 4 - Reações com persulfato em função do pH (ITRC, 2005).

\begin{tabular}{cc}
\hline Solução & Reação \\
\hline Neutra & $\mathrm{S}_{2} \mathrm{O}_{8}{ }^{2-}+2 \mathrm{H}_{2} \mathrm{O} \rightarrow 2 \mathrm{HSO}_{4}{ }^{-}+1 / 2 \mathrm{O}_{2}$ \\
\hline Ácida Diluída (pH 3-7) & $\mathrm{S}_{2} \mathrm{O}_{8}{ }^{2-}+2 \mathrm{H}_{2} \mathrm{O} \stackrel{\mathrm{H}^{+}}{\rightarrow} 2 \mathrm{HSO}_{4}{ }^{-}+\mathrm{H}_{2} \mathrm{O}_{2}$ (formação de peróxido) \\
\hline Extremamente ácida & $\mathrm{S}_{2} \mathrm{O}_{8}{ }^{2-}+2 \mathrm{H}_{2} \mathrm{O} \stackrel{\mathbf{H}^{+}}{\rightarrow} \mathrm{HSO}_{4}{ }^{-}+\mathrm{HSO}_{5}{ }^{-}$ \\
\hline Alcalina (pH>13) & $\mathrm{S}_{2} \mathrm{O}_{8}{ }^{2-}+\mathrm{OH}^{-} \rightarrow \mathrm{HSO}_{4}{ }^{-}+\mathrm{SO}_{4}{ }^{2-}+1 / 2 \mathrm{O}_{2}$ \\
\hline
\end{tabular}

A utilização de catalisadores permite a formação de radicais sulfatos os quais possuem potencial padrão de redução maior do que íon persulfato, 2,6 e 2,1V, respectivamente. A formação de radicais livres de sulfato está vinculada a presença de calor no meio ou de catalisadores como, por exemplo, ferro bivalente $\left(\mathrm{Fe}^{++}\right)$(eq. 1) (Liu et al., 2014).

$$
\mathrm{S}_{2} \mathrm{O}_{8}{ }^{2-}+\mathrm{Fe}^{++} \rightarrow \mathrm{Fe}^{+++}+\mathrm{SO}_{4}^{-}+\mathrm{SO}_{4}^{-\cdot}(1)
$$

Os radicais sulfato podem iniciar uma série de reações de radical em cadeia, as semi-reações seguem descritas na Tabela 5, onde os compostos orgânicos (M) são usualmente degradados.

Tabela 5 - Semi-reações formadas ao longo da oxidação por persulfato (HUANG, 2002).

\begin{tabular}{|c|}
\hline $\mathrm{S}_{2} \mathrm{O}_{8}{ }^{2-} \rightarrow \mathbf{2} \mathrm{SO}_{4}{ }^{-\bullet}$ (reações de início de cadeia) \\
\hline $\mathrm{S}_{2} \mathrm{O}_{8}{ }^{2-}+\mathrm{M} \rightarrow \mathbf{2} \mathbf{S O}_{4}{ }^{-\cdot}+\mathrm{M}^{\bullet}$ (reações de início de cadeia) \\
\hline $\mathrm{SO}_{4}^{-\cdot}+\mathrm{H}_{2} \mathrm{O} \rightarrow \mathrm{OH}^{\cdot}+\mathrm{HSO}_{4}^{-}$(reações de propagação) \\
\hline $\mathbf{S O}_{4}{ }^{-}+\mathrm{M} \rightarrow \mathrm{M}^{\bullet}+$ produtos (reações de propagação) \\
\hline $\mathrm{OH}^{-\bullet}+\mathrm{M} \rightarrow \mathrm{M}^{\bullet}+$ produtos (reações de propagação) \\
\hline $\mathrm{M}^{\cdot}+\mathrm{S}_{2} \mathrm{O}_{8}{ }^{2-} \rightarrow 2 \mathrm{SO}_{4}{ }^{-\cdot}+$ produtos (reações de propagação) \\
\hline $\mathbf{S O}_{4}^{-\cdot}+\mathrm{OH}^{\cdot} \rightarrow$ terminação de cadeia \\
\hline $\mathbf{S O}_{4}^{-}{ }^{-}+\mathbf{M}^{\bullet} \rightarrow$ terminação de cadeia \\
\hline $\mathbf{2 S O}_{4}{ }^{-\cdot} \rightarrow$ terminação de cadeia \\
\hline $\mathrm{OH}^{\bullet}+\mathrm{M}^{\bullet} \rightarrow$ terminação de cadeia \\
\hline $\mathrm{OH}^{\bullet} \rightarrow$ terminação de cadeia \\
\hline $2 \mathrm{M}^{\cdot} \rightarrow$ terminação de cadeia \\
\hline
\end{tabular}

Ao todo, a formação dos radicais ocorre em três estágios. O primeiro chamado de iniciação (eq. (2) e Tabela 5), quando os primeiros radicais são formados, seguido pela propagação (eq. (3) e Tabela 5) quando novos radicais são gerados e a terminação quando 
os radicais são removidos do sistema. Além disso, segundo Elloy et al. (2014) durante as reações de propagação são gerados radicais hidroxila $\left(\mathrm{OH}^{-}\right)$eq. (3) e Tabela 5.

$$
\begin{gathered}
\mathrm{S} 2 \mathrm{O}^{2-}+2 \mathrm{Fe}^{++} \rightarrow \mathrm{SO}_{4}{ }^{2-}+2 \mathrm{Fe}^{+++}+\mathrm{SO}^{-\bullet}(2) \\
\mathrm{SO}^{-\bullet}+\mathrm{H} 2 \mathrm{O} \rightarrow \mathrm{HO}^{\bullet}+\mathrm{HSO}^{-}(3)
\end{gathered}
$$

A constante k para a reação de formação de radicais livres eq. (2) seria equivalente a 9,9 x $10^{8}$ (HECKEL et al., 1966 apud Peyton, 1993). De acordo com os autores, dentre as espécies inorgânicas, o ferro é a espécie que mais é oxidada no processo.

Comparando o potencial padrão de redução do persulfato com demais aníons formados a partir de outros oxidantes verifica-se que este é ligeiramente inferior apenas ao potencial do ozônio e superior aos demais apresentados (RODRIGUES, 2006) (Tabela 6).

Tabela 6 - Potencial padrão de redução.

\begin{tabular}{ccc}
\hline Oxidante & Reações & $\begin{array}{c}\text { Potencial } \\
\text { padrão }\end{array}$ \\
\hline Persulfato & $\mathrm{S}_{2} \mathrm{O}_{8}{ }^{2-}+2 \mathrm{e}^{-} \rightarrow \mathrm{SO}_{4}{ }^{2-}$ & $\mathrm{E}^{0}=2,1 \mathrm{~V}$ \\
\hline Ozônio & $\mathrm{O}_{3}+2 \mathrm{H}^{+}+2 \mathrm{e}^{-} \rightarrow \mathrm{O}_{2}+\mathrm{H}_{2} \mathrm{O}$ & $\mathrm{E}^{0}=2,07 \mathrm{~V}$ \\
\hline Peróxido & $\mathrm{H}_{2} \mathrm{O}_{2}+2 \mathrm{H}^{+}+2 \mathrm{e}^{-} \rightarrow 2 \mathrm{H}_{2} \mathrm{O}$ & $\mathrm{E}^{0}=1,78 \mathrm{~V}$ \\
\hline Permanganato & $\mathrm{MnO}_{4}{ }^{-}+4 \mathrm{H}^{+}+3 \mathrm{e}^{-} \rightarrow \mathrm{MnO}_{2}+2 \mathrm{H}_{2} \mathrm{O}$ & $\mathrm{E}^{0}=1,70 \mathrm{~V}$ \\
\hline
\end{tabular}

No geral, o persulfato mostra-se mais vantajoso para a oxidação in situ do que os demais oxidantes convencionais, pois possui maior persistência no aquífero em relação ao peróxido de hidrogênio, as reações não geram calor a ponto de causar um ambiente inseguro, não produzem precipitados ao contrário das reações com o permanganato, é incolor ao contrário do permanganato, é menos prejudicial para os microrganismos presentes naturalmente no meio, consegue atingir maior zona de influência devido à maior solubilidade (FERRARESE, 2008).

Vantagens da utilização do persulfato em relação aos demais são conhecidas, mas pouco se sabe a respeito do mecanismo de reação com a fração mineral do meio. $\mathrm{O}$ mecanismo da oxidação pelo persulfato de algumas espécies orgânicas encontradas naturalmente em alguns meios foi apresentado por Peyton (1993). Segundo o autor, após a formação de aníons de radicais sulfatos, a reação com compostos orgânicos poderá ocorrer por três maneiras diferentes, sendo elas: remoção do átomo de hidrogênio, transferência de elétrons e aumento de ligações. Os radicais de sulfato reagem com certos grupos funcionais como anéis aromáticos, aminas e carboxilas por meio da transferência de elétrons (Figura 4) (PEYTON, 1993). 


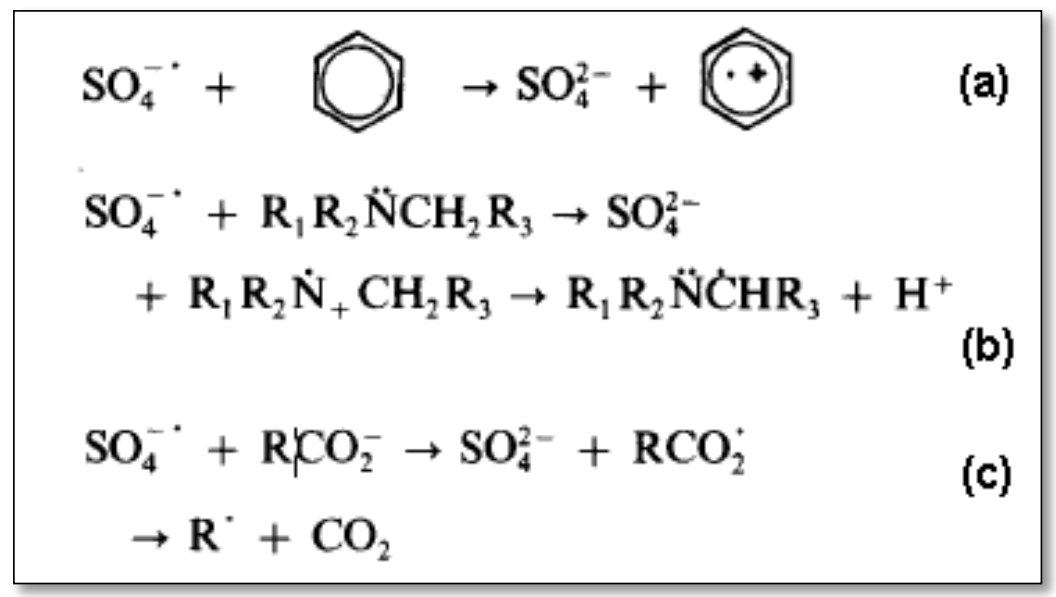

Figura 4 - Reação do persulfato com compostos orgânicos a) reação do radical sulfato com anel aromático; b) reação do radical sulfato com grupo amina; c) reação do radical sulfato com grupo carboxila (PEYTON, 1993).

Além do mecanismo da reação deste oxidante com as espécies redutoras, deve-se compreender a cinética dessas reações, já que a relação entre a velocidade da reação e a velocidade do fluxo da água influenciará na eficiência da remediação. Vários estudos realizados a partir de testes de batelada mostraram que a decomposição de diversos compostos orgânicos (metil tert-butil éter, o fármaco antipirina e o herbicida diuron) a partir da reação com o persulfato, apresentou cinética de pseudo primeira ordem (HUANG et al., 2002; TAN et al. 2012; NAVARRO, 2013). Nestes estudos, não foi avaliado a cinética de degradação do persulfato, mas sim dos compostos orgânicos.

Huang et at. (2002) afirmaram que a decomposição do composto orgânico quando colocado em contato com o persulfato seguia cinética de pseudo primeira ordem pois apesar de poder haver várias espécies oxidantes no sistema, como por exemplo, radicais sulfato $\left(\mathrm{SO}_{4}{ }^{-}\right)$, radicais hidroxilas $(\mathrm{OH} \cdot)$, aníon persulfato $\left(\mathrm{S}_{2} \mathrm{O}_{8}{ }^{-2}\right)$ e o íon bissulfato $\left(\mathrm{HSO}_{4}{ }^{-}\right)$, muito provavelmente o radical sulfato seria a espécie predominante.

Outras pesquisas ainda observaram que a cinética de decomposição de alguns compostos orgânicos seguia o modelo de segunda ordem (TSITONAKI et al. 2010; BUXTON et al. 1988).

A equação a seguir demonstra o balanço estequiométrico da oxidação direta do contaminante Tricloroeteno $\left(\mathrm{C}_{2} \mathrm{HCl}_{3}\right.$ - TCE) pelo persulfato de sódio (ITRC, 2005).

$$
3 \mathrm{Na}_{2} \mathrm{~S}_{2} \mathrm{O}_{8}+\mathrm{C}_{2} \mathrm{HCl}_{3}+4 \mathrm{H}_{2} \mathrm{O} \rightarrow 2 \mathrm{CO}_{2}+9 \mathrm{H}^{+}+3 \mathrm{Cl}^{-}+6 \mathrm{Na}^{+}+6 \mathrm{SO}_{4}{ }^{2-}(4)
$$

Considerando o balanço estequiométrico apresentado, caso o persulfato não interagisse com o meio de modo a diminuir sua capacidade de oxidação do composto alvo e a reação ocorre-se por meio da transferência direta de elétrons, a relação entre o número 
de mols persulfato de sódio e o Tricloroeteno seria de 3:1. Contudo, esta relação não é verdadeira devido à presença de espécies redutoras presentes no meio.

O persulfato além de reagir por oxidação direta também pode reagir através da formação de radical sulfato. A oxidação do benzeno pelo persulfato através da oxidação por formação de radicais livres gera como produto dióxido de carbono e água eq. (6) (LIANG, 2011).

$$
\begin{gathered}
\mathrm{S}_{2} \mathrm{O}_{8}{ }^{2-}+\text { catalisador } \rightarrow 2 \mathrm{SO}_{4}{ }^{--} \text {ou }\left(\mathrm{SO}_{4}{ }^{2-}+\mathrm{SO}_{4}{ }^{-}\right) \\
16 \mathrm{Na}_{2} \mathrm{~S}_{2} \mathrm{O}_{8}+\mathrm{C}_{6} \mathrm{H}_{6}+12 \mathrm{H}_{2} \mathrm{O} \rightarrow 6 \mathrm{CO} 2+30 \mathrm{H}^{+}+32 \mathrm{Na}^{+}+32 \mathrm{SO}_{4}{ }^{2-}
\end{gathered}
$$

Sendo assim, considerando o balanço estequiométrico, seriam necessários 16 mols de persulfato de sódio para oxidar apenas $1 \mathrm{~mol}$ de benzeno caso o oxidante não interagisse com o solo.

\subsection{Interação entre Oxidantes e Solos}

A demanda natural de oxidante do solo, também conhecida como demanda natural do solo, refere-se à presença de compostos orgânicos e inorgânicos que ocorrem naturalmente no solo e na água subterrânea e que irão reagir e consumir de forma finita o oxidante. De acordo com Haselow et al., (2003) há diversos fatores químicos e físicos que contribuem para esta demanda. Segundo Jones (2007), os compostos que podem interagir com os oxidantes são espécies reduzidas presentes no aquífero, sendo elas inorgânicas como ferro, manganês e enxofre, ou espécies orgânicas.

Haselow et al., 2003 também listaram a presença de minerais reduzidos em fase dissolvida ou adsorvida como causadores do consumo de oxidantes em subsuperfície. No entanto, o consumo do oxidante por parte dos minerais reduzidos dependerá do potencial de redução do meio bem como da composição química da matriz sólida como, por exemplo, da concentração de ferro. Em vista disso, a compreensão a respeito da interação do oxidante com a matriz sólida é fundamental para que se possa dimensionar o projeto de remediação utilizando esta tecnologia.

A interação do reagente Fenton com o solo poderá formar por exemplo, precipitado de oxihidróxido férrico e consequentemente obstruir os poros, já que durante o processo ocorre a oxidação do ferro bivalente, o qual poderá ser novamente reduzido, contudo somente em condições extremamente ácidas, com $\mathrm{pH}$ inferior a 1 (PIGNATELLO et al., 2006). Além disso, os autores citam como desvantagem a suscetibilidade desta espécie ser consumida pela matéria orgânica natural do solo. Silva 
et al. (2012) avaliaram a interação do oxidante Fenton com dois tipos de solos brasileiros, um deles com predomínio de caulinita 1:1 e outro com minerais 2:1. De acordo com os resultados dos autores, houve uma redução no teor de carbono orgânico equivalente a 30 e 56\% no solo com predomínio de argilominerais 1:1 e 2:1, respectivamente. Os autores relacionaram ainda, a redução da fração orgânica com a diminuição na capacidade de troca de cátions (CTC) prejudicando assim a fertilidade do solo. Os autores observaram também alteração na mineralogia dos argilominerais 2:1.

A CTC é uma das formas de avaliar a capacidade de sorção de cátions do solo, já que é calculada por meio da quantificação dos cátions como sódio, potássio, manganês, alumínio e hidrogênio adsorvidos a fração mineral. Este parâmetro é comumente utilizado para avaliação da fertilidade do solo já que os cátions adsorvidos pelos minerais são utilizados como nutrientes para as plantas. Em relação ao processo de oxidação, pode-se dizer que este parâmetro também é valido pois poderá indicar, ainda que qualitativamente, a capacidade do solo em adsorver o contaminante inorgânico.

Outra interação que pode ser citada é aquela observada por Appelo e Postma (2005). Os autores demonstraram que tanto a oxidação da siderita $\left(\mathrm{Fe}\left(\mathrm{CO}_{3}\right)\right)$, da pirita $\left(\mathrm{FeS}_{2}\right)$ e da rodocrosita $\left(\mathrm{MnCO}_{3}\right)$ pelo permanganato formam precipitado de dióxido de manganês $\left(\mathrm{MnO}_{2}\right)$ bem como de ferro no caso da oxidação da siderita e da pirita. A formação de precipitados não é favorável para a remediação já que provoca o entupimento dos poros reduzindo consequentemente o espalhamento da solução oxidante e a zona de influência da oxidação.

Li e Schwartz (2000) verificaram por meio de experimento em um tanque 2D que a massa de fase liquida não aquosa mais densa que a água (dense non aqueous phase liquid - DNAPL) removida através da oxidação por permanganato era eficiente no início do processo, mas com o passar do tempo havia um decréscimo drástico na remoção devido ao entupimento dos poros com dióxido de manganês. Lee et al. (2003) também observaram obstrução dos poros devido à formação do óxido de manganês o qual foi identificado como sendo um subproduto de cor preta formado especialmente na área fonte.

Em relação ao oxidante persulfato, cita-se que este possui maior interação com minerais reduzidos presentes no solo do que com a matéria orgânica propriamente dita, apesar de também poder interagir com a matéria orgânica (SRA et al., 2010).

Liang et al. (2008) verificaram por meio de teste com coluna deformada, a tendência do persulfato oxidar preferencialmente a matéria orgânica ao invés do 
contaminante Tricloroeteno. Huang et al. (2002) afirmou que a aplicação do persulfato seguida pela do permanganato permitiria a oxidação dos constituintes redutores presentes no solo antes da oxidação do alvo da remediação. Segundo o autor, o persulfato oxidaria a fração orgânica e os minerais enquanto que o permanganato atacaria o contaminante, alvo da remediação.

Eusterhues et al. (2003) oxidaram amostras de dois solos diferentes em diversas profundidades de modo a avaliar todo o perfil do solo e assim diferenciar a interação com diferentes tipos de matéria orgânica. De acordo com os autores, as amostras referentes ao topo do perfil apresentaram uma pequena fração de carbono orgânico resistente à oxidação por persulfato de sódio. No entanto, a porcentagem de carbono orgânico que não foi oxidado pelo persulfato aumentou com a profundidade, chegando a $80 \%$ em um dos tipos de solo utilizados (Cambissolo Distrófico). Os autores afirmaram ainda que esta resistência é devido à presença de carbono orgânico representado tanto por alcatrão quanto por carvão.

Além da solubilidade do sal, deve-se atentar a outras características relacionadas aos cátion presente no sal do oxidante durante a seleção do oxidante a ser utilizado na remediação, já que eventualmente este também poderá interferir em algumas propriedades do solo, como por exemplo, na dispersão das partículas. O tipo de cátion do sal e a quantidade presente poderá favorecer a dispersão das partículas, alterando a permeabilidade do meio.

Cátions com alto grau de hidratação como sódio podem ser adsorvidos na superfície do mineral por meio da formação de complexos, e por estarem altamente hidratados aumentam seu raio iônico, formando complexos de esfera externa, ou seja, favorecem ligações na superfície do mineral aumentando a distância entre as partículas dos minerais e evitando a manifestação de forças atrativas de curto alcance. Isso pode favorecer a dispersão dos coloides, e consequentemente o entupimento de poros inicialmente maiores (MEURER, 2010).

De acordo com Fetter (2008), o sódio é um dispersante importante, pois a dupla camada eletrostática formada é maior na presença deste cátion tendendo assim a enfraquecer as ligações entre as partículas de argila. Já no caso da aplicação do potássio em certas concentrações, verifica-se que pelo fato deste possuir menor grau de hidratação, formará preferencialmente complexos de esfera interna minimizando assim a repulsão entre as partículas (EVANGELOU, 1998; MEURER, 2010). 
Em concentrações elevadas, as soluções salinas podem reduzir a porosidade do solo, visto que podem provocar a expansão do mineral devido à expansão da dupla camada difusa das argilas. Assim, com a expansão da argila, os espaços dos poros poderão ser preenchidos (FETTER, 2008). O efeito da expansão da partícula é reversível se a solução salina é escoada pelos poros. Contudo, caso pequenas partículas se soltem da estrutura do solo, elas poderão ser transportadas pelo fluxo da água até poros menores, onde poderão permanecer alojadas. Quando pequenas partículas são dispersas e lixiviadas até poros menores, a redução da condutividade hidráulica é parcialmente reversível (DANE \& KLUTE, 1977 apud FETTER, 2008).

Sendo assim, já que o persulfato utilizado para fins de remediação é formado por sais de potássio ou sódio, eventualmente a presença desses cátions poderá interferir no balanço das cargas de superfície dos minerais de modo a prejudicar o grau de floculação dos coloides do solo.

Ainda não existe um modelo preciso que estime a demanda natural de oxidante a partir da determinação da quantidade de minerais reduzidos e de carbono orgânico. O que se faz atualmente são ensaio pilotos em laboratório e em campo para verificação da demanda de oxidante do solo ou demanda natural de oxidante ou ainda demanda total de oxidante (HASELOW et al., 2003). Thomson (2010) comenta que estes termos devem ser utilizados com cautela uma vez que a interação do solo com o oxidante nem sempre significa consumo finito do oxidante, ou seja, nem sempre pode ser classificado como demanda. No caso do persulfato, o termo demanda não é utilizado já que este não aparenta ter uma massa finita a ser consumida por constituintes do solo.

Liu et al. (2014) concluíram que o decaimento do persulfato, devido a interação com minerais de aquíferos, segue o modelo de pseudo primeira ordem, sendo que a constante da taxa do decaimento varia proporcionalmente com a superfície específica do solo. Os autores demonstraram que a relação entre a taxa de decaimento do persulfato e a área específica do solo pode ser descrita pela equação a seguir:

$$
\frac{d\left[S_{2} o_{8}^{2-}\right\rfloor}{d t}=-K_{o b s}\left[S_{2} O_{8}^{2-}\right]=-K_{n o r m}\left(C_{S}\right)\left[S_{2} O_{8}^{2-}\right]
$$

$K_{\text {obs }}:$ constate de pseudo primeira ordem $\mathrm{s}^{-1}$;

Knorm: constante normalizada $(L \cdot m-2 \cdot S-1)$;

Cs: superfície específica dos sólidos em suspensão $\left(\mathrm{m}^{2} \cdot \mathrm{L}^{-1}\right)$.

Considerando a equação expressa por Liu et al. (2014) e que solos com maior teor de argila e carbono orgânico possuem maiores superfícies especificas, acredita-se que em 
solos brasileiros a aplicação do persulfato para fins de remediação poderá ter sua eficiência comprometida caso não seja considerado durante a elaboração do projeto a interação do persulfato com a matriz sólida, pois a taxa de depleção do persulfato será acentuada em alguns solos brasileiros devido ao valores de superfície específica elevados.

Sra et al., (2007) citaram que o sucesso da oxidação com persulfato e o custo-benefício da oxidação não depende apenas da forma em que o oxidante é colocado no meio, ou seja, não depende apenas da tecnologia de injeção empregada, mas também da compreensão a respeito da interação do persulfato com o alvo da contaminação e o meio. Sra et al. (2008) avaliaram a persistência do persulfato em diversos solos e puderam observar que a decomposição do persulfato seguia cinética de pseudo primeira ordem provavelmente devido à decomposição catalítica do oxidante. Pelo fato da concentração do catalisador ser constante, sua concentração pode ser incluída na constante da taxa.

Sra et al. (2010) estimaram, por meio de teste de bancada e com colunas deformadas com sete tipos de solo diferentes de região de clima temperado, parâmetros da cinética de decomposição do persulfato. Os autores observaram que em todos os ensaios a decomposição do persulfato foi de primeira ordem e que a constante da taxa de

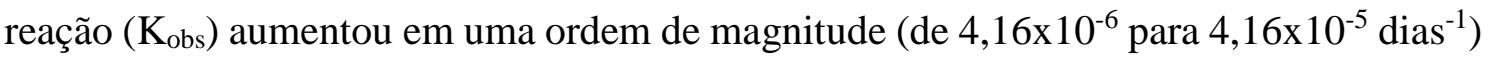
quando a concentração utilizada de oxidante foi reduzida em vinte vezes, de $20 \mathrm{~g} / \mathrm{L}$ para $1 \mathrm{~g} / \mathrm{L}$. De acordo com os autores, em sistemas com concentrações mais elevadas do oxidante, a estabilidade do persulfato é superior devido ao aumento da força iônica da solução a qual é controlada pela concentração inicial de persulfato.

Em relação aos valores do coeficiente de reação ( $\left.\mathrm{K}_{\text {obs}}\right)$ obtidos pelos autores para os testes realizados com coluna deformada foi aproximadamente 8 vezes maior do que o teste de bancada realizado na mesma concentração $(1 \mathrm{~g} / \mathrm{L})$. O decaimento do persulfato nos testes em coluna também apresentou decaimento de primeira ordem. Apesar do modelo de decaimento das concentrações de persulfato ter se ajustado a um decaimento de primeira ordem, inesperadamente foi observado pelos autores variação na constante da taxa de reação quando a concentração inicial era alterada (SRA et al., 2010).

Apesar de, em geral, ser esperado que em meios homogêneos formados por areia a oxidação pode ser mais eficiente devido a menor demanda natural de oxidante ou menor interação, os resultados de Crimi e Siegrist (2005) indicaram que em certas condições a oxidação de contaminantes em meios heterogêneos, o qual pode exercer maior demanda de oxidante ou interação, pode ser mais eficaz e eficiente do que em meio formados por areias homogêneas. Uma condição observada foi à presença consistente de ácidos 
húmicos, resultando no aumento da porcentagem de contaminante destruído embora a taxa de depleção tenha diminuído. De acordo com os autores, a presença de ácido húmico pode ter resultado no aumento na taxa de dessorção e/ou dissolução do contaminante.

Alguns autores têm avaliado a capacidade dos minerais do solo em favorecer a oxidação do persulfato por meio da catálise metálica (HYUN, 2010; AHMAD et al. 2010; TEEL et al. 2011; USMAN et al. 2012; YAN el. al. 2013 \& Liu, et al. 2014). Recentemente, Liu et al. (2014) demostraram que a ativação do persulfato por meio de minerais presentes naturalmente no solo ocorre conforme ilustrado na Figura 5.

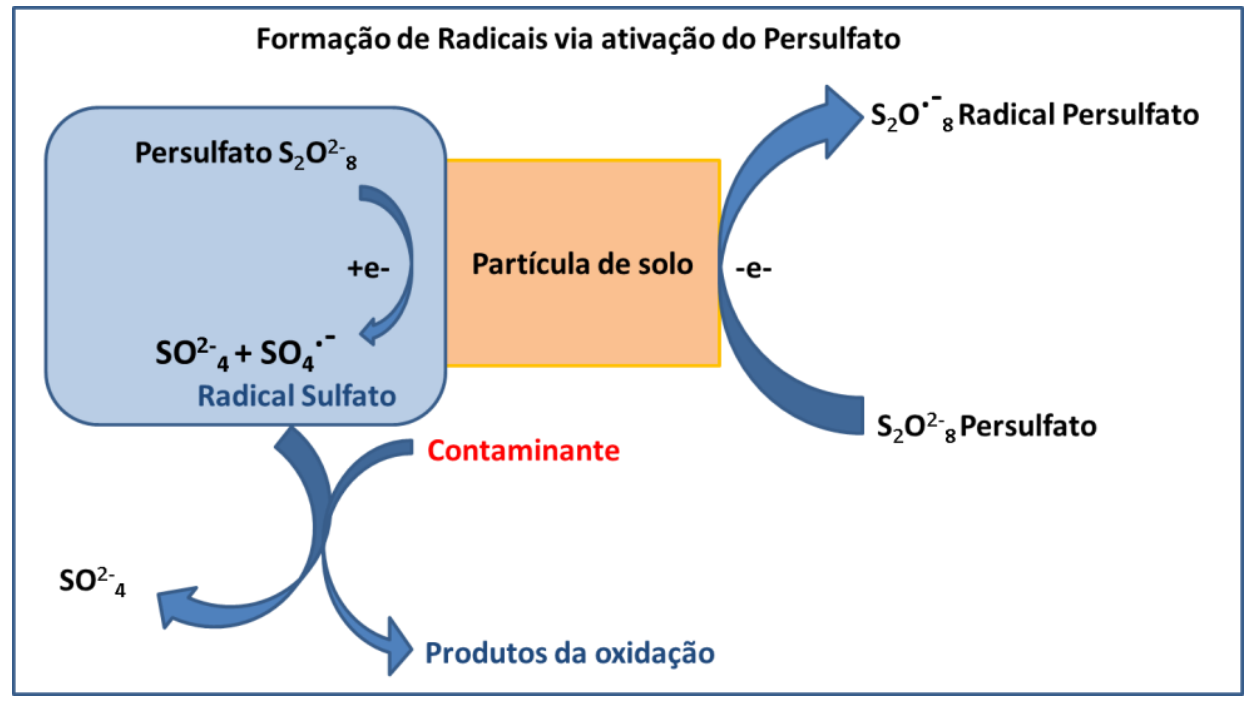

Figura 5 - Formação de radicais via ativação do persulfato (Fonte: Haizhou Liu, 2014).

Por outro lado, Usman et al. 2012, citam que o ferro solúvel não seria capaz de acelerar significativamente a oxidação de PAH (apenas em 20\%), ao passo que com a aplicação de magnetita $\left(\mathrm{Fe}_{3} \mathrm{O}_{4}\right)$ aumentaria a eficiência em $90 \%$. A interação entre o ferro $2+$ e $3+$ presente na superfície do óxido (ex. magnetita) poderia então ocorrer da seguinte forma:

$$
\equiv \mathrm{FeII}+\mathrm{S}_{2} \mathrm{O}_{8}{ }^{2-} \rightarrow \equiv \mathrm{FeIII}+\mathrm{SO}_{4}{ }^{--}+\mathrm{SO}_{4}{ }^{2-}
$$

Apesar de essa interação favorecer a formação de radical sulfato, a interação do aníon de persulfato com este mineral ainda não é bem conhecida, mas foi relatado que o ferro ligado à superfície do mineral pode atuar como consumidor de radicais sulfato como seria o caso também do radical hidroxila (USMAN et al. 2012).

$$
\equiv \mathrm{FeII}+\mathrm{SO}_{4}{ }^{-} \rightarrow \equiv \mathrm{FeIII}+\mathrm{SO}_{4}{ }^{2-}
$$

Além disso, os autores revelam que para diferentes minerais com ferro ligados em sua superfície apresentam interações discrepantes com o persulfato de modo que alguns podem ativar o persulfato enquanto outros não. Usman et al. (2012), perceberam que 
minerais com predomínio de ferro bivalente (pirita) podem interagir melhor com o persulfato favorecendo sua ativação do que minerais com predomínio de ferro trivalente (hematita). Outro fator limitante indicado pelos autores refere-se à solubilidade do mineral e a natureza da superfície do mineral.

Ahmad et al., (2010) avaliaram a interação do persulfato na presença de três óxidos de ferro (goethita, hematita, ferrihidrita), um de manganês (birnessita) e dois argilominerais (caulinita e montmorilonita) em sistemas com $\mathrm{pH}$ ácido $(<7)$ e alcalino (>12). Os autores observaram neste estudo que a decomposição do persulfato seguiu o decaimento de primeira ordem, sendo que em meio ácido num período de 30 dias a decomposição do persulfato foi inferior a $15 \%$ na presença de todos os minerais citados. Assim como Ahmad et al. (2010), Liu et al. (2014) verificaram similaridade no mecanismo de reação do persulfato com o do peróxido de hidrogênio. Os minerais com maior interação foram respectivamente: birnessita (15\%), goethita (13\%) enquanto a hematita, ferrihidrita, montmorollonita e caulinita promoveram a decomposição de aproximadamente $8 \%$. Em ambiente alcalino, o persulfato degradou-se rapidamente na presença da ferrihidrita com degradação de $24 \%$ passados 30 dias. Nesta condição alcalina a degradação do persulfato não apresentou variações significativas entre os minerais: hematita, birnessita e goethita $(15-18 \%)$. Os argilominerais foram os que menos promoveram a decomposição do persulfato $(<6 \%)$. Com isso, os autores concluíram que tanto em meio ácido ou alcalino, os óxidos de ferro e manganês foram responsáveis pelas maiores taxas de degradação do persulfato enquanto os argilominerais apresentaram menores taxas (LIU et al., 2014). As taxas da catálise mediada por minerais são normalmente proporcionais à área de superfície do mineral (KHAN E WATTS, 1996; VALENTINE E WANG, 1998; KWAN e VOELKER 2003 apud AHMAD et al., 2010).

Considerando os mecanismos de reação do persulfato e a composição mineralógica dos solos tropicais, em especial o Latossolo, possivelmente projetos de remediação por oxidação química in situ, que utilizam o persulfato como agente oxidante sem controle do $\mathrm{pH}$ da solução, possam ter sua eficiência reduzida devido a interação do persulfato com a fração orgânica e principalmente com a fração mineral desses solos e/ ou favorecer a formação de radicais por meio da catálise metálica. 


\section{MATERIAIS E MÉTODOS}

Para compreender as possíveis interações entre o oxidante e o solo, e identificar os principais constituintes do solo que interagem com o oxidante, foram realizados ensaios de oxidação em batelada (Figura 6) e em coluna indeformada (Figura 7). Nos testes em batelada, além da oxidação do solo, foram realizados ensaios físicos, químicos e mineralógicos a fim de caracterizar inicialmente as amostras de solo e avaliar as alterações devido à oxidação (Tabela 7).

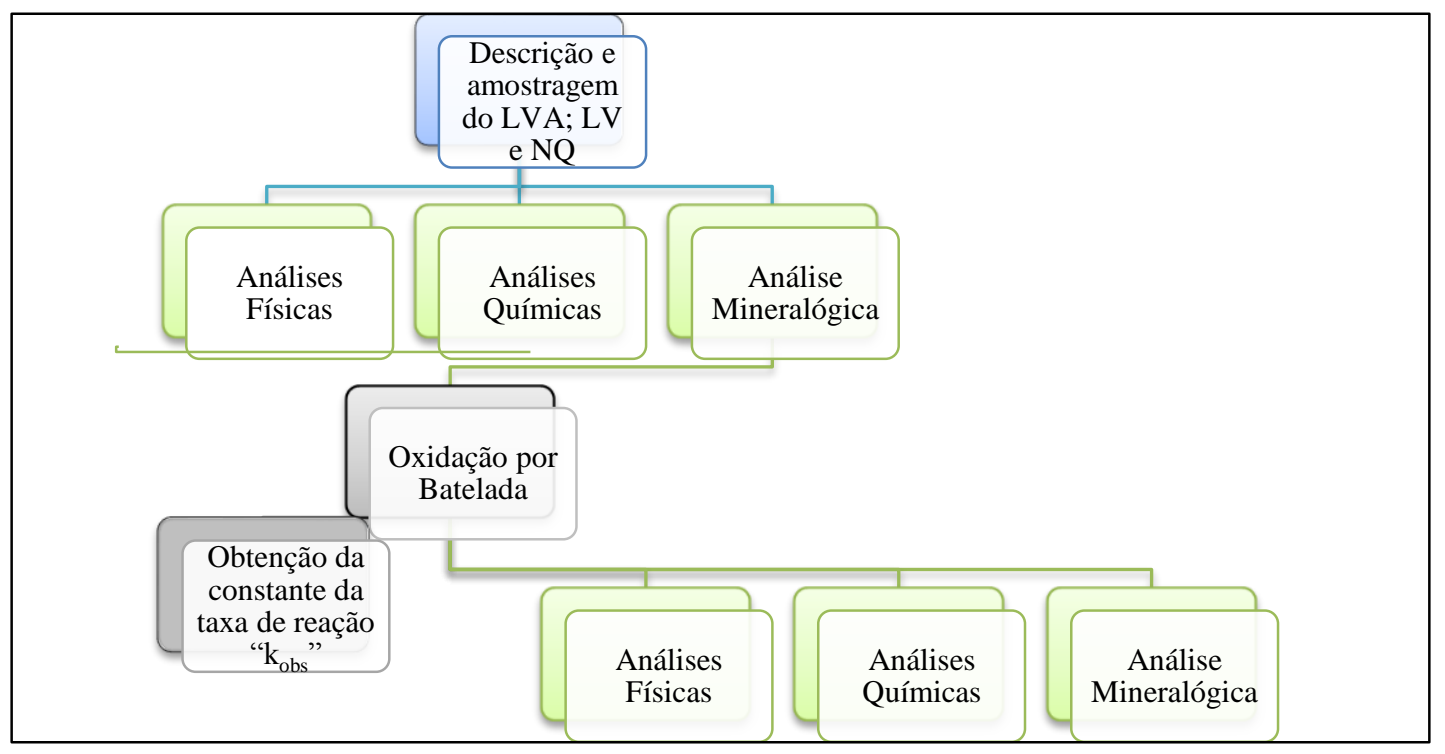

Figura 6 - Fuxograma do experimento realacionado a oxidação por batelada.

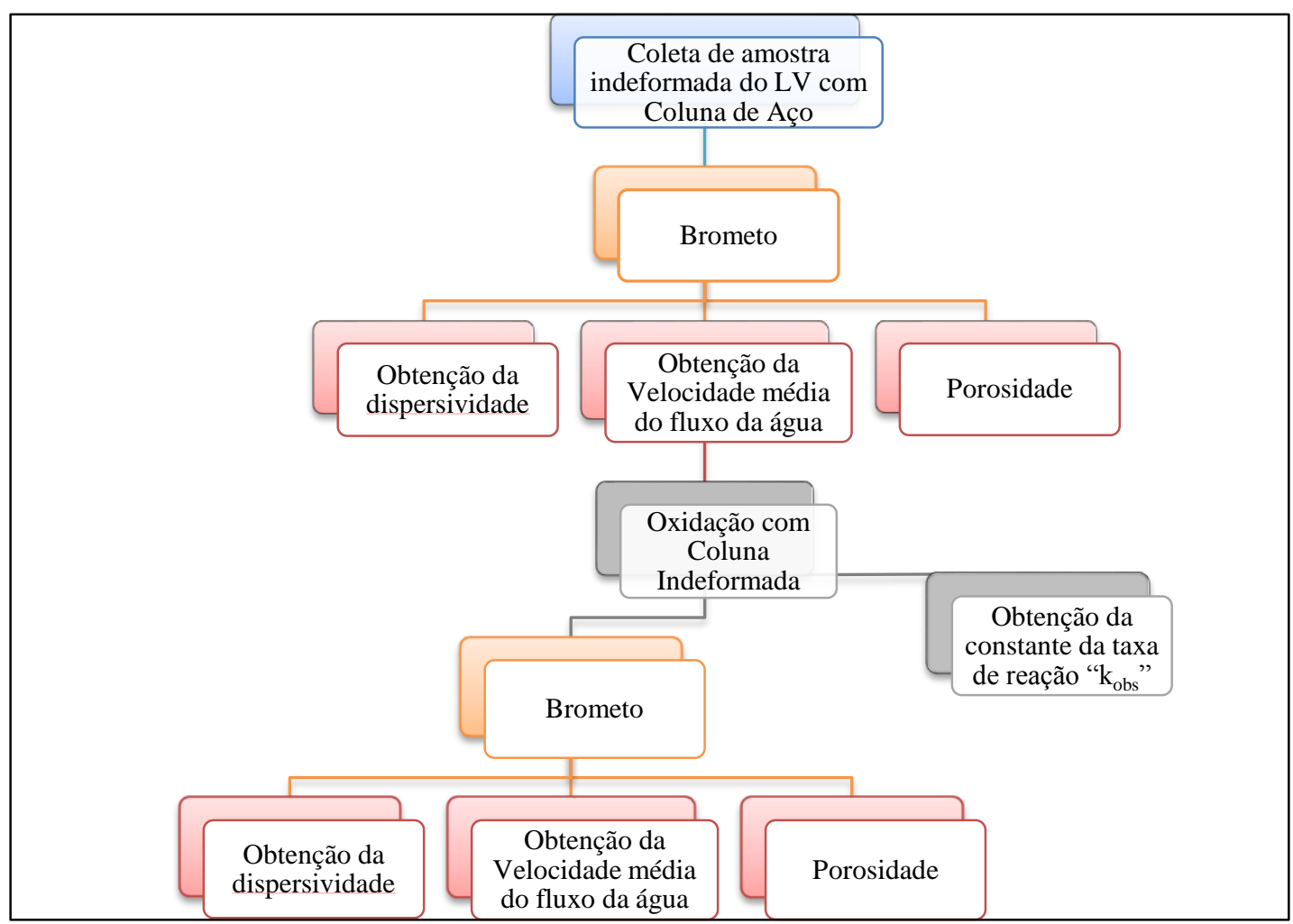

Figura 7: Fluxograma do experimento realacionado a oxidação por coluna. 
Para entender as alterações no fluxo da água subterrânea decorrentes da aplicação de oxidante foi empregado ensaio com coluna indeformada, onde foram aplicados traçadores capazes de representar os processos de advecção e dispersão de solutos no meio poroso. Estes ensaios são representativos e amplamente utilizados para avaliação de transporte de solutos em meio subterrâneo saturado (LEWIS \& SJOSTROM 2010; LIANG et al., 2011). Por meio do ensaio com coluna indeformada foi possível determinar a propriedades hidráulicas do meio como condutividade hidráulica, dispersividade e coeficiente de dispersão antes e depois da oxidação.

Em estudos relacionados a interação do oxidante com o solo nota-se que para a caracterização das amostras a maioria dos autores analisam: granulometria, o potencial hidrogeniônico do solo, superficie específica, a capacidade de troca catiônica do solo, carbono total ferro e manganês (XU \& THOMSON, 2009; SRA, et, al. 2010; AHMAD et al., 2010 e LIANG et al., 2011). Na presente pesquisa os ensaios realizados para essa avaliação seguem na Tabela 7.

Tabela 7 - Ensaios físico, químicos e mineralógico realizado nas amostras de solo.

\begin{tabular}{|c|c|}
\hline Análises físicas: & Análises Químicas: \\
\hline 1. Granulometria & 1. Carbono orgânico (CO) \\
\hline 2. Área Específica & 2. Carbono inorgânico $(\mathrm{CI})$ \\
\hline 3. Grau de floculação* & 3. Carbono Total (CT) \\
\hline 4. Densidade aparente* & 4. Capacidade de Troca Catiônica (CTC) \\
\hline 5. Densidade de partículas* & 5. Determinação do $\mathrm{pH}$ em $\left(\mathrm{H}_{2} \mathrm{O} ; \mathrm{KCl}\right)$ \\
\hline 6. Superfície específica* & 8. Ponto de carga zero $(\mathrm{PCZ})^{*}$ \\
\hline 7. Porosidade; & 9. Extração sequencial de ferro \\
\hline 8. Condutividade hidráulica & \\
\hline Análise Mineralógica: & Análise térmica. \\
\hline $\begin{array}{l}\text { 1. Difração por raio X da fração } \\
\text { argila total }\end{array}$ & $\begin{array}{l}\text { 1. Curva Termogravimetria (TG) e Termogravimetria derivada } \\
\text { (DTG) }\end{array}$ \\
\hline
\end{tabular}


Tabela 8 - Parâmetros determinados e respectivos métodos analíticos.

\begin{tabular}{cc}
\hline Parâmetro & Método \\
\hline Quantificação do persulfato & HUANG et al., 2002; KODAK, 2003. \\
\hline Análise granulométrica (SILVA, 2013; BOSSI, 2014) & EMBRAPA, 1997 (ADAPTADO) \\
\hline Análise do grau de floculação & EMBRAPA, 1997(ADAPTADO) \\
\hline Determinação do carbono orgânico e inorgânico & SSM-5000A (Solid Sample Module) \\
\hline Cátions e Aníons & EMBRAPA, 1997. \\
\hline pH $\left(\mathrm{H}_{2} \mathrm{O}\right), \mathrm{pH}(\mathrm{KCl})$ e $\Delta \mathrm{pH}$ & EMBRAPA, 1997. \\
\hline PCZ & CAMARGO et al., 2009 \\
\hline CTC efetiva & EMBRAPA, 1997. \\
\hline Densidade aparente & CAMARGO et al., 2009 \\
\hline Densidade de partículas & CAMARGO et al., 2009 \\
\hline Porosidade & EMBRAPA, 1997 \\
\hline Condutividade & CAMARGO et al., 2009 \\
\hline Hidráulica & SILVEIRA et al., 2006 \\
\hline Extração sequencial & CAMARGO et al., 2009 \\
\hline Análise Mineralógica & Termogravimetria (TG) e \\
\hline Análise Térmica & Termogravimetria derivada (DTG). \\
\hline
\end{tabular}

\subsection{Seleção e Coleta das Amostras Deformadas}

Para a seleção dos solos a serem utilizados na pesquisa foi levado em consideração à ocorrência e a distribuição dos solos no Brasil. Além disso, foram consideradas as propriedades dos solos, como estruturação e mineralogia. Os tipos de solo selecionados foram: o Latossolo Vermelho (LV), o Latossolo Vermelho Amarelo (LVA) e o Neossolo Quartzarênico (NQ). Salienta-se que o Neossolo Quartzarênico foi selecionado a fim de contrastar seus resultados com os dos Latossolos, pois este apresenta características significativamente diferentes dos Latossolos, como por exemplo, área específica e textura.

Os solos foram caracterizados em campo seguindo os procedimentos publicados pelo IBGE (2007). A descrição do solo no campo visa registrar as características do solo através do exame do seu perfil em seu ambiente natural. Desta forma, a caracterização foi feita de modo a delimitar os horizontes pedológicos, suas respectivas morfologias e transições. Os parâmetros avaliados em campo para caracterização das amostras compreenderam: espessura, cor por meio da comparação com as cores da tabela de Munsell, transição para o horizonte subjacente, textura, estrutura, grau de estrutura, consistência do solo seco e úmido e cerosidade. 
Os Latossolos foram coletados na cidade de Piracicaba/SP enquanto que o Neossolo em São Carlos/SP. Inicialmente foi coletado o Latossolo Vermelho Amarelo,

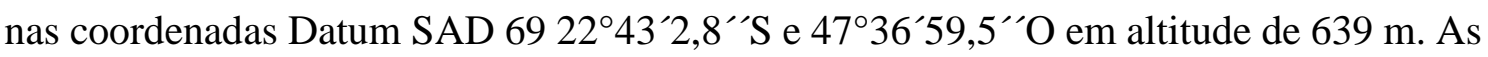
amostras do LVA foram coletadas entre 0,70 e $0,85 \mathrm{~m}$ de profundidade no horizonte $\mathrm{B}$, dentro na trincheira 5 do campus da Escola Superior de Agricultura "Luiz de Queiroz" da Universidade de São Paulo em Piracicaba/SP. O horizonte B foi selecionado para a coleta das amostras por ser o horizonte de diagnóstico do Latossolo e por deter nesta camada acúmulos de minerais.

Na sequência fez-se a descrição e coleta das amostras deformadas do Latossolo Vermelho. O ponto de coleta destas amostras é na Rodovia Luiz de Queiroz, km 155 ,

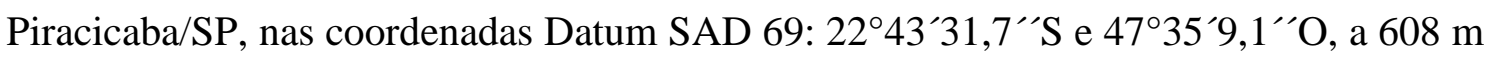
de altitude. As amostras deformadas também foram coletadas após a descrição do perfil do solo, também no horizonte $\mathrm{B}$, abaixo dos $0,85 \mathrm{~m}$ de profundidade.

As amostras deformadas do Neossolo Quartzarênico foram coletadas na estação

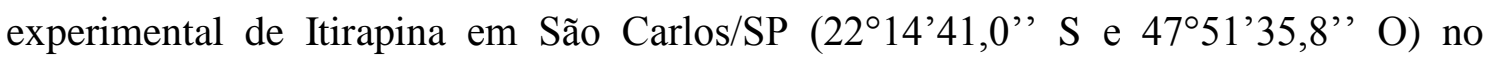
horizonte $\mathrm{C} 2$ abaixo de 1,37 $\mathrm{m}$ de profundidade. O horizonte $\mathrm{C} 2$ foi o selecionado por apresenta menor influência de raízes.

Em estudo prévio, os autores Silva (2014) e Bossi (2014) fizeram a caracterização granulométrica das amostras de solo coletadas para a presente pesquisa. Os autores verificaram que o erro da análise foi equivalente a 1,9\%; 4,9\% e 4,6\% respectivamente para as amostras NQ, LVA e LV. O erro para as amostras de Latossolo foram mais expressivos devido ao maior grau de agregação das partículas de argila, em especial do Latossolo Vermelho. Para reduzir o erro decorrente da agregação das partículas de argila os autores adaptaram o método por meio da adição de $5 \mathrm{~g}$ de areia. A Tabela 9 possui a porcentagem das frações granulométricas observadas por Silva (2014) e Bossi (2014).

Tabela 9 - Porcentagem das frações granulométricas nas amostras antes da oxidação.

\begin{tabular}{ccccccccc}
\hline \multirow{2}{*}{ Amostra } & \multicolumn{9}{c}{ Areia \% } & \multirow{2}{*}{ Silte \% } & Argila \% \\
& MG & Grossa & Média & Fina & MF & Total & & \\
\hline LVA & 0,2 & 1,6 & 11,6 & 25,1 & 35,4 & 73,9 & 2,7 & 23,4 \\
\hline LV & 2 & 0 & 3,9 & 5,6 & 9,9 & 21,4 & 6,5 & 67,5 \\
\hline NQ & 2,3 & 5,9 & 13,3 & 41,5 & 25 & 88 & 3,3 & 8,7 \\
\hline
\end{tabular}

MG: Muito grossa; MF:Muito fina. 


\subsection{Preparação das amostras}

Não há na literatura uma quantidade significativa de trabalhos relacionados à amostragem e a preservação das amostras de solo para fins de determinação da interação com oxidante. Nem sempre os autores citam como foi realizado o pré-tratamento das amostras de solo. Contudo, no geral as amostras de solo são secas ao ar e em seguida peneiradas, sendo que a fração maior que 2,0 mm é removida (XU \& THOMSON, 2009).

Xu e Thomson (2009) avaliaram a variação na capacidade redutora do material coletado quando os mesmo são pré-tratados de formas diferentes. Os autores armazenaram as amostras de solo saturadas em caixa onde foram mantidas condições anaeróbias por meio da injeção continua de gás nitrogênio. Em seguida as amostras foram divididas em duas partes, sendo uma seca ao ar e outra seca a $80^{\circ} \mathrm{C}$. Com base nos resultados obtidos não foi verificada diferenças significantes para os dois grupos de amostra. Entretanto, os autores observaram variações significativas para amostras com teor igual ou maior do que $3 \mathrm{mg} / \mathrm{kg}$ de composto orgânico total. Para este tipo de material foi verificada a necessidade de manter as amostras refrigeradas a $<4^{\circ} \mathrm{C}$ e secagem em estufa a $80^{\circ} \mathrm{C}$ (XU \& THOMSON, 2009).

Considerando que o horizonte onde foram coletadas as amostras dos Latossolos trata-se do Horizonte B latossólico, ou seja, horizonte onde há acumulo de minerais e a fração orgânica é relativamente inexpressiva, após a coleta as amostras foram encaminhadas para laboratório e mantidas a temperatura ambiente. Nas amostras do Neossolo também não se esperava encontrar teores acentuados de matéria orgânica, já que durante a descrição do perfil foi possível observar que as amostras eram de areia inconsolidada de coloração clara e, portanto, sem indícios de teores elevados de carbono orgânico. As amostras foram pré tratadas por meio da secagem ao ar por aproximadamente 20 dias. As amostras secas foram esboroadas com rolha de borracha, frascos de porcelana e pistilo. Logo após, as amostras foram peneiradas em peneira de $2 \mathrm{~mm}$ a fim de obter terra fina seca ao ar (TFSA). Após a preparação as amostras foram mantidas a temperatura ambiente.

\subsection{Análises Físicas}

\subsection{1 Área Específica}

As áreas específicas das amostras foram caracterizadas no laboratório da Universidade Federal de São Paulo através de um equipamento de Fissorção e Quimissorção da marca Quantachrome Instruments, modelo NovaWin, o qual mediu a 
área específica através do método desenvolvido por Brunauer, Emmett e Teller (BET), ou seja, através da determinação do volume de gás adsorvido fisicamente na superfície da amostra. Para tanto foi utilizado gás de Nitrogênio.

\subsubsection{Grau de Floculação}

Para determinação do grau de floculação (eq. 10) foram utilizados os resultados dos ensaios de granulometria apresentados por Silva (2014) e Bossi (2014) obtidos a partir da utilização do dispersante químico para quantificação da argila total e a partir da utilização apenas de água destilada para quantificação da argila dispersa em água.

$$
G F \%=100(\text { At }- \text { Adn }) / A t
$$

Sendo que,

GF (\%): grau de floculação;

At (g): argila dispersa total (obtida com a aplicação do dispersante químico); e

Adn (g): argila dispersa naturalmente (obtida com a utilização de água destilada como dispersante).

\subsubsection{Densidade de Partículas}

Para a determinação da densidade de partículas ( $\boldsymbol{\rho}$ ) foi adotado a metodologia do balão volumétrico e álcool etílico (EMBRAPA, 1997). Este método permite o cálculo da densidade por meio da determinação do volume de álcool necessário para completar a capacidade de um balão volumétrico contendo TFSA.

Foi colocado num balão volumétrico de $50 \mathrm{~mL}, 20 \mathrm{~g}$ de TFSA. Em seguida, uma proveta de $50 \mathrm{~mL}$ foi preenchida com álcool etílico 95\% (Synth). Aproximadamente $25 \mathrm{~mL}$ do álcool da proveta foi transferido para o balão com a TFSA. Na sequência agitou-se manualmente o balão de modo a garantir o completo umedecimento das partículas, evitando a permanência de bolhas de ar dentro do balão. Após o umedecimento das partículas, o balão foi completado com o álcool presente na proveta. Para obtenção da densidade de partículas, dividiu-se então a massa de TFSA (20g) pelo volume de álcool restante na proveta (eq. 11). O resultado final foi obtido através da média aritmética dos resultados das triplicatas.

$$
\rho_{a}\left(\frac{g}{c m^{3}}\right)=T F S A / 50-V_{\text {álcool gasto }}
$$




\subsubsection{Densidade Aparente e Porosidade}

A densidade aparente é a relação entre a massa total de solo pelo volume total do solo (CAMARGO et al., 2009). Para determinação da densidade aparente do solo, utilizou-se o método do anel volumétrico. Um cilindro oco de aço com a borda inferior cortante (anel volumétrico) cujo volume é conhecido $\left(50 \mathrm{~cm}^{3}\right)$ é cravado na profundidade desejada. As amostras coletadas por meio da cravação deste anel são consideradas amostras indeformadas, ou seja, amostras de solo com a estruturação tridimensional preservada.

Foram coletadas 3 amostras indeformadas do LV no Horizonte $\mathrm{B}$, a aproximadamente $1 \mathrm{~m}$ de profundidade, para determinação da densidade aparente pela média aritmética das réplicas. Para tanto foi empregado em campo um amostrador de solo tipo Uhland no qual o anel volumétrico foi acoplado com a parte cortante voltada para baixo, e com auxílio de um martelo emborrachado foi possível cravar o anel no perfil do solo na profundidade desejada. Após a coleta, as amostras foram envolvidas em papel filme e alumínio e em seguida foram identificadas. No laboratório as amostras foram mantidas sobre refrigeração até o momento da realização do ensaio.

Inicialmente foi colocada uma tela de nylon tanto na porção superior quanto inferior do anel e em seguida fez-se a saturação das amostras com gás carbônico por meio da passagem de um fluxo de gás carbônico (100\%) ascendente a uma pressão constante de 0,5 psi $\left(3447 \mathrm{~N} / \mathrm{m}^{2}\right)$ durante 15 minutos. Este fluxo visou à completa substituição do ar presente nos poros pelo gás carbônico, o qual é solúvel em água.

Os anéis foram colocados dentro de um dessecador contendo água desaerada até a interface do anel. Por meio de uma bomba de vácuo, foi mantido vácuo no sistema por 5 minutos a fim de iniciar a saturação dos poros através do fluxo ascendente. As amostras permaneceram em repouso por 12 horas para completa saturação dos poros. Por capilaridade a água em contato com a parte inferior do anel ascendeu até completa saturação do solo.

Após a etapa de saturação, as amostras foram pesadas e secas em estufa a $105^{\circ} \mathrm{C}$ por 24h. Passado o período de secagem as mesmas foram pesadas novamente para obtenção da massa de solo seco. A densidade aparente $\left(\boldsymbol{\rho}\right.$, em $\left.\mathrm{g} / \mathrm{cm}^{3}\right)$ foi então obtida pela razão da massa de solo seco (Mss, em g) e o volume do cilindro (Va, em $\mathrm{cm}^{3}$ ) eq.(12).

$$
\rho a\left(\frac{g}{c m 3}\right)=M s s / V a
$$


A porosidade total é a relação entre o volume total de poros e o volume total da amostra. Para obtenção desta medida, também foram utilizadas amostras indeformadas. O método adotado foi desenvolvido por Embrapa (1997). Este parâmetro foi determinado apenas para as amostras do Latossolo Vermelho já que este foi o solo selecionado para o ensaio de oxidação através da coluna indeformada onde um dos objetivos foi avaliar a alteração nas propriedades hidráulicas do solo.

Conhecendo a massa de sólidos (solo seco) bem como a densidade de partículas obteve-se o volume de sólidos. Pela diferença entre o volume de sólidos e o volume total do anel foi possível obter o volume de poros e pela razão deste com o total chegou-se a sua porosidade total eq.(13).

$$
n \%=\frac{[\text { Vcilindro }-(\text { Msólidos } \times D p)] \times 100}{V \text { cilindro }}
$$

Sendo que;

n (\%): Porosidade total;

$\mathrm{V}_{\text {Cilindro }}\left(\mathrm{cm}^{3}\right)$ : Volume total do cilindro;

Msólidos (g): Massa de sólidos;

$\boldsymbol{\rho}\left(\mathrm{g} / \mathrm{cm}^{3}\right)$ : Densidade de partículas;

\subsubsection{Condutividade Hidráulica}

A condutividade hidráulica foi determinada em 8 amostras indeformadas coletadas com anel volumétrico no Horizonte B do LV a 1m de profundidade (Tabela 10). Para tanto, as amostras foram previamente saturadas e colocadas dentro de um permeâmetro (Eijkelkamp). Estabelecido um fluxo constante e ascendentes de água pelas amostras, aguardou-se a estabilização do gradiente hidráulico e em seguida aferiu-se a vazão e o gradiente hidráulico para o cálculo da condutividade por meio do fluxo da Lei de Darcy (eq. 14 a 16). 
Tabela 10 - Amostras Indeformadas coletadas no Horizonte B do LV para determinação da condutividade hidráulica.

\begin{tabular}{ccccc}
\hline $\begin{array}{c}\text { Identificação } \\
\text { da Amostra }\end{array}$ & $\begin{array}{c}\text { Profundidade de } \\
\text { coleta }(\mathrm{m})\end{array}$ & $\begin{array}{c}\text { Data da } \\
\text { Coleta }\end{array}$ & $\begin{array}{c}\text { Data da } \\
\text { realização do } \\
\text { ensaio }\end{array}$ & $\begin{array}{c}\text { Repetição do } \\
\text { Ensaio após } \\
\text { oxidação das } \\
\text { amostras }\end{array}$ \\
\hline $\mathbf{1 . 1}$ & 1,17 & $01 / 03 / 13$ & $16 / 04 / 13$ & \\
\hline $\mathbf{1 . 2} *$ & 1,17 & $01 / 03 / 13$ & $16 / 04 / 13$ & $11 / 07 / 13$ \\
\hline $\mathbf{1 . 3}$ & 1,17 & $01 / 03 / 13$ & $16 / 04 / 13$ & \\
\hline $\mathbf{1 . 4} *$ & 1,17 & $01 / 03 / 13$ & $16 / 04 / 13$ & $11 / 07 / 13$ \\
\hline $\mathbf{2 . 2}$ & 1,20 & $17 / 04 / 13$ & $25 / 04 / 13$ & \\
\hline $\mathbf{2 . 3}$ & 1,30 & $17 / 04 / 13$ & $25 / 04 / 13$ & $11 / 07 / 13$ \\
\hline $\mathbf{2 . 4}$ & 1,35 & $17 / 04 / 13$ & $25 / 04 / 13$ & \\
\hline $\mathbf{2 . 5}$ & 1,40 & $17 / 04 / 13$ & $25 / 04 / 13$ & \\
\hline
\end{tabular}

* amostras deixadas imersas em solução de persulfato após determinação da condutividade inicial para realização de novos ensaios.

$$
\begin{gathered}
q=-K \times i \\
q(\mathrm{~cm} / \mathrm{s})=\frac{Q}{A} \\
|K|=\frac{Q \times L}{h \times A}
\end{gathered}
$$

Sendo que,

q (cm/s): Fluxo de Darcy;

$\mathrm{K}(\mathrm{cm} / \mathrm{s})$ : condutividade hidráulica;

i $(\mathrm{cm} / \mathrm{cm}):$ Gradiente Hidráulico $=\Delta \mathrm{h} / \Delta \mathrm{L}$;

$\Delta \mathrm{h}(\mathrm{cm})$ : variação de carga hidráulica;

$\mathrm{L}(\mathrm{cm})$ : Comprimento da coluna de solo pela qual ocorre o fluxo de água;

$\mathrm{Q}\left(\mathrm{cm}^{3} / \mathrm{s}\right):$ Vazão;

A: área da seção transversal $\left(\mathrm{cm}^{2}\right)$.

A velocidade da água (v) será então equivalente à razão entre o fluxo de Darcy e a porosidade (n) eq. (17).

$$
v=\frac{q}{n}(\mathbf{1 7})
$$

Após determinação da condutividade hidráulica, a amostra 1.2 foi mantida imersa durante 79 dias em $500 \mathrm{~mL}$ de solução de $14 \mathrm{~g} / \mathrm{L}$ de persulfato. A amostra 1.4 foi mantida imersa em solução de $28 \mathrm{~g} / \mathrm{L}$ persulfato durante o mesmo período e a amostra 2.3 também 
foi mantida imersa em solução de $28 \mathrm{~g} / \mathrm{L}$ de persulfato durante 62 dias. Após este período repetiu-se o experimento para determinação da condutividade hidráulica das amostras.

Uma das concentrações adotadas neste ensaio é referente à concentração utilizada no ensaio de oxidação com batelada (14g/L) e a outra o dobro desta concentração.

\subsubsection{Análise Térmica}

Ensaios termogravimétricos foram realizados nas amostras de solo LV, LVA e NQ antes e após a oxidação realizada por ensaio de batelada, para determinação dos principais componentes do solo antes e após a oxidação. Para tanto, utilizou-se um Analisador Termogravimétrico (TG/DTA) da marca Shimadzu, modelo DTG-60H da Universidade Federal de São Paulo. As análises ocorreram em uma atmosfera controlada por nitrogênio com fluxo de $50 \mathrm{~mL} / \mathrm{min}$, a temperatura de até $900^{\circ} \mathrm{C}$ alcançada num intervalo de 10min. Os resultados obtidos são apresentados através de termogramas.

Para a quantificação dos minerais caulinita e gibbsita utilizou-se o método proposto por Lima (2010) sem a realização da desferrificação da amostra.

\subsection{Análises Químicas}

\subsubsection{Capacidade de Troca Catiônica Efetiva e pH}

Para obtenção dos valores de capacidade de troca catiônica (CTC), as amostras foram enviadas para o laboratório da Escola Superior de Agricultura "Luiz de Queiroz" da Universidade de São Paulo. Foram quantificadas as concentrações em mmolc/kg dos cátions potássio $\left(\mathrm{K}^{+}\right)$, cálcio $\left(\mathrm{Ca}^{2+}\right)$ e magnésio $\left(\mathrm{Mg}^{2+}\right)$ pelo método de acetato de amônio, bem como foi quantificada a concentração de alumínio $\left(\mathrm{Al}^{3+}\right)$ pelo método de extração por cloreto de potássio $(\mathrm{KCl}(1 \mathrm{~mol} / \mathrm{L}))$ e hidrogênio mais alumínio $\mathrm{H}^{+}+\mathrm{Al}^{3+}$ pelo método de extração por acetato de cálcio dihidratado $\left(\mathrm{Ca}\left(\mathrm{CH}_{3} \mathrm{OO}\right) 2 \cdot \mathrm{H}_{2} \mathrm{O}\right)$. A CTC foi calculada pela soma das bases trocáveis mais hidrogênio e alumínio.

Além deste parâmetro, foram analisados no laboratório da ESALQ os valores de pH em água e em solução de $\mathrm{KCl}$. A medição do pH em solução de $\mathrm{KCl}$ e do pH em água foi feita a partir de uma proporção de solo:líquido de 1:2,5 (RAIJ et al., 2001).

\subsubsection{Ponto de Carga Zero}

O ponto de carga zero foi determinado no ponto de cruzamento entre três curvas de titulação potenciométricas em soluções eletrolíticas de $\mathrm{KCl}$ através do método proposto pela EMBRAPA (1997). Para o experimento foram pesados $4 \mathrm{~g}$ de solo para cada um dos 18 frascos utilizados para determinação do $\mathrm{pH}$. Em seguida, foram 
preparadas 18 soluções com concentração de $\mathrm{KCl}$ equivalente a 0,001; 0,01 e 0,1M. Para cada solução salina foram preparas 6 novas soluções as quais passaram a ter 0;0,002; 0,004; 0,008M de $\mathrm{HCl}$ e 0,002; 0,004 e 0,008M de $\mathrm{Na}(\mathrm{OH})$. Foram adicionados $20 \mathrm{~mL}$ de cada uma das soluções em diferentes fracos já com $4 \mathrm{~g}$ de solo, totalizando assim 18 frascos com o mesmo tipo de solo e com soluções eletrolíticas diferentes. A cada 5 mim fez-se a agitação das amostras com auxílio de um agitador horizontal durante um intervalo de $24 \mathrm{~h}$. Em seguida fez-se as leituras de pH das soluções do solo e por fim os dados foram plotados em gráficos bidimensionais.

\subsubsection{Carbono Total, Inorgânico e Orgânico}

Para determinação do carbono total (CT) presente nas amostras empregou-se um analisador de carbono total VCPN da marca Shimadzu o qual encontra-se acoplado a um SSM-5000A (Solid Sample Module). O SSM-5000A realiza a análise em amostras sólidas por meio da combustão completa da amostra.

No tubo de combustão de carbono total, todo o carbono presente na amostra sofre combustão a $900^{\circ} \mathrm{C}$ ou decomposição para se tornar gás carbônico $\left(\mathrm{CO}_{2}\right)$. Feito isto, o gás de arraste que agora contém o carbono total é resfriado e seco por um desumidificador e é em seguida enviado para um analisador de gás infravermelho (NDIR) onde o $\mathrm{CO}_{2}$ é detectado. O sinal emitido gera um pico que tem sua área calculada pelo processador de dados. O pico gerado é proporcional à concentração de carbono total da amostra e o resultado é dado em porcentagem de massa.

Com o equipamento previamente calibrado através da construção da curva de calibração com glicose $\left(\mathrm{R}^{2}=0,99\right)$, fez-se a leitura de carbono total em triplicata a partir de $30 \mathrm{mg}$ de TFSA. Contudo, devido à baixa quantidade de carbono nas amostras de solo foi necessário aumentar a massa de solo para obtenção da porcentagem mássica de carbono total.

A Tabela 11 possui as massas utilizadas para a determinação da concentração de carbono nas amostras do LVA, LV e do NQ antes e após a oxidação. Para o LV, a partir de 200 mg de TFSA foi possível detectar massa de carbono, já para o LVA e NQ foi necessário ao menos 800 e 2000 mg de TFSA, respectivamente. 
Tabela 11 - Massa de TFSA utilizada para determinação de carbono total.

\begin{tabular}{ccc}
\hline \multirow{2}{*}{ Solo } & \multicolumn{2}{c}{ Massa de TFSA } \\
\cline { 2 - 3 } & Pré-oxidação (mg) & Pós-oxidação (mg) \\
\cline { 2 - 3 } Latossolo & 253,8 & 967,9 \\
\cline { 2 - 3 } Vermelho-Amarelo (LVA) & 556,3 & 951,2 \\
\cline { 2 - 3 } & 822,7 & $1.001,0$ \\
\cline { 2 - 3 } & 938,2 & $1.004,0$ \\
\hline \multirow{3}{*}{ Latossolo Vermelho (LV) } & $1.065,8$ & - \\
\cline { 2 - 3 } & 310,7 & 307,5 \\
\cline { 2 - 3 } & 295,9 & 313,7 \\
\hline \multirow{2}{*}{ Neossolo } & 253,1 & 574,3 \\
\cline { 2 - 3 } Quartzarênico (NQ) & 250,3 & 256,8 \\
\cline { 2 - 3 } & $1.144,5$ & 1983,5 \\
\cline { 2 - 3 } & $1.034,9$ & - \\
\cline { 2 - 3 } & 811,4 & - \\
\hline
\end{tabular}

Esta análise foi repetida com as amostras de TFSA após o ensaio de oxidação por batelada a fim de avaliar a degradação do carbono durante a oxidação. Devido à necessidade de repetir alguns ensaios químicos, para a determinação do carbono total nas amostras de solo NQ pós-oxidação só foi possível fazer teste em duplicata.

Para a determinação do carbono inorgânico (CI) foi adotado o mesmo método equipamento, sendo que a única diferença foi que para a combustão das amostras, o forno foi mantido a $200^{\circ} \mathrm{C}$ e as amostras foram acidificadas por meio da adição de ácido fosfórico concentrado.

\subsubsection{Extração Sequencial do Ferro}

Com intuito de avaliar a distribuição do ferro nas amostras de solo adotou-se a metodologia de extração sequencial proposta por Silveira et al. (2006), e utilizada por Nachtigall (2007) e Nogueirol (2010). Este método foi desenvolvido especificamente para a extração sequencial de alguns metais em amostras de solos de clima tropical, os quais possuem elevado conteúdo de óxido de ferro e de manganês. Este método extraiu mais ferro do que o método proposto por Tessier (1979) e por Ahnstrom \& Parker (1999), os quais são apropriados para solos de clima temperado onde há predomínio de minerais $2: 1$.

A extração do metal em formas diferentes ocorre a partir de uma mesma amostra, sendo que as frações avaliadas foram: solúvel e trocável, ligado a matéria orgânica, ligado a óxido de ferro mal cristalizado, ligado a óxido de ferro cristalino. Para a extração do 
ferro de cada uma das frações, as amostras foram mantidas em contato com a solução específica por tempo suficiente para extrair o metal. A Tabela 12 resume as frações de extração e as condições utilizadas para a realização de cada uma delas.

Tabela 12 - Frações de ferro, soluções extratoras e condições para a extração sequencial.

\begin{tabular}{|c|c|c|c|c|}
\hline & Frações & Solução & Tempo & Temperatura ${ }^{\circ} \mathrm{C}$ \\
\hline 1 & Solúvel-trocável & $15 \mathrm{~mL} 0,1 \mathrm{M} \mathrm{CaCl}_{2}+1 \% \mathrm{HNO}_{3}$ & $2 \mathrm{~h}$ & Ambiente \\
\hline 2 & Matéria Orgânica & $5 \mathrm{~mL} \mathrm{NaOCl}+1 \% \mathrm{HNO}_{3}(\mathrm{pH} 8.5)$ & $30 \mathrm{~min}$ & $90-95$ \\
\hline 3 & $\begin{array}{l}\text { Óxido de Fe mal } \\
\text { cristalizado }\end{array}$ & $\begin{array}{c}30 \mathrm{~mL}^{0,2} \mathrm{M} \text { ácido oxálico + 0,2 } \\
\mathrm{M} \mathrm{NH}_{4} \text { oxalato }(\mathrm{pH} \mathrm{3})\end{array}$ & $2 \mathrm{~h}$ & Ambiente \\
\hline 4 & Óxido de Fe cristalino & $40 \mathrm{~mL} 6 \mathrm{M} \mathrm{HCl}$ & $24 \mathrm{~h}$ & Ambiente \\
\hline
\end{tabular}

Inicialmente, aproximadamente $5 \mathrm{~g}$ de solo foi esboroado e peneirado em peneira de 100 mesh (1mm). Em seguida transferiu-se $1 \mathrm{~g}$ de solo para tubos Falcon de $50 \mathrm{~mL}$. Esta análise foi realizada em triplicata para todas as amostras. Na sequência foi preparada a primeira solução extratora $(\mathrm{F} 1)$ de cloreto de cálcio dihidratado $\left(\mathrm{CaCl}_{2} \cdot 2 \mathrm{H}_{2} \mathrm{O}\right)(0,1 \mathrm{M})$ preparada por meio da adição de $14,70 \mathrm{~g}$ do sal $\mathrm{CaCl}_{2} \cdot 2 \mathrm{H}_{2} \mathrm{O}$ (Merck) em $1 \mathrm{~L}$ de água MiliQ. Após homogeneização da solução, foram adicionados $15 \mathrm{~mL}$ da solução em cada um dos tubos Falcon. Os tubos foram mantidos na posição horizontal por $2 \mathrm{~h}$ em agitação em mesa agitadora horizontal a $180 \mathrm{rpm}$. Em seguida as amostras foram centrifugadas por $15 \mathrm{~min}$ a $3000 \mathrm{rpm}$ e a $1844 \mathrm{G}$.

Depois de centrifugadas, o sobrenadante foi filtrado em papel filtro Nalgon 2 micras de filtragem lenta com 12,5 cm de diâmetro, e o filtrado foi despejado em balão volumétrico de $25 \mathrm{~mL}$. Após filtragem foi adicionado em cada tubo Falcon $5 \mathrm{~mL}$ de solução de $\mathrm{NaCl}(0,1 \mathrm{M})$ (Synth).

Adicionada a solução de $\mathrm{NaCl}(0,1 \mathrm{M})$, os tubos Falcon foram agitados com a mão e em seguida centrifugados nas mesmas condições anteriores. A solução separada foi então adicionada ao extrato inicial obtido. Este passo tem por objetivo evitar a readsorção do metal na próxima fração a ser extraída.

No extrato final foi adicionada 1 gota de ácido nítrico concentrado em cada um dos balões volumétricos. Na sequência os balões foram completados com água MiliQ e a solução foi homogeneizada com a mão. Finalizada a primeira etapa da extração, o extrato foi transferido para tubos Falcon de $15 \mathrm{~mL}$ identificados e as amostras foram preservadas na geladeira.

Para a segunda extração (F2) foram adicionados $5 \mathrm{~mL}$ de hipoclorito de sódio (5\%) (marca Nalgon) ajustado no mesmo dia o pH para 8,5 com $\mathrm{HCl}(2 \mathrm{M})$. Para tanto 
empregou-se um pHmêtro calibrado no momento do ajuste da solução. Feito o ajuste a adição dos $5 \mathrm{~mL}$ de hipoclorito, os tubos falcon foram agitados com a mão e deixados em banho-maria por 30 minutos a $90^{\circ} \mathrm{C}\left( \pm 1^{\circ} \mathrm{C}\right)$. Os tubos permaneceram abertos durante o banho. Após o banho-maria, aguardou-se o resfriamento das amostras e então as mesmas foram centrifugadas. Em seguida a solução sobrenadante foi filtrada em balão de $50 \mathrm{~mL}$.

Este procedimento foi repetido por mais 3 vezes, totalizando 4 repetições. Feita a quarta e última extração a quente com hipoclorito, adicionou-se $5 \mathrm{~mL}$ da solução de $\mathrm{NaCl}$ $(0,1 \mathrm{M})$ em cada um dos frascos os quais foram agitados na mão e centrifugados. A solução sobrenadante foi então filtrada sobre o mesmo filtro de papel utilizado para filtrar as quatro soluções de $5 \mathrm{~mL}$ de hipoclorito. Por fim, adiciou-se 1 gota de ácido nítrico e completou-se os balões com água MiliQ.

Os balões foram então agitados com a mão para homogeneização da solução e em seguida transferiu-se $15 \mathrm{~mL}$ da solução para tubos Falcon de $15 \mathrm{~mL}$, identificados previamente. $\mathrm{O}$ extrato foi preservado em geladeira até o dia da leitura das concentrações de ferro.

Para realizar a terceira extração (F3), relacionada ao ferro ligado a óxidos amorfo, foi necessário inicialmente revestir os tubos Falcon com papel alumínio (110 x 145cm) assim como os tubos Falcon de $15 \mathrm{~mL}$ utilizados para armazenar o extrato final.

Na sequência foram preparados 1,5 L de: 0,2M de ácido oxálico (Synth) + 0,2M de oxalato de amônio (Synth) + 0,1M de ácido ascórbico (Synth), solução está ajustada a pH 3,0 com adição de solução $\mathrm{Na}(\mathrm{OH}) 50 \%$ (Vetec) no momento do preparo da solução o qual foi o mesmo dia da extração.

Para o preparo da solução acima, foi dissolvido em béquer de $500 \mathrm{~mL}, 17,61 \mathrm{~g}$ de ácido ascórbico em aproximadamente $200 \mathrm{~mL}$ de água MiliQ assim como foi dissolvido em outro béquer de $500 \mathrm{~mL}, 28,42 \mathrm{~g}$ de oxalato de amônio em aproximadamente $300 \mathrm{~mL}$ de água MiliQ aquecida por 10s no microondas com potência média. Num terceiro béquer de $500 \mathrm{~mL}$ foi adicionado $25,12 \mathrm{~g}$ de ácido oxálico o qual foi dissolvido com aproximadamente $200 \mathrm{~mL}$ de água MiliQ aquecida por 10s no microondas com potência média.

Feito isso, os béqueres contendo as soluções foram levados para um ambiente escuro onde se fez a mistura das soluções em béquer de $2 \mathrm{~L}$ a fim de evitar a degradação do oxalato na presença da luz. Após a mistura das soluções fez-se o ajuste do pH para 3 com solução de $\mathrm{NaOH} 50 \%$. Aguardou-se a solução esfriar e em seguida a mesma foi transferida para balão volumétrico de $1 \mathrm{~L}$ o qual foi aferido com água MiliQ. 
Ainda no escuro foi adicionado em cada tubo Falcon previamente revestido com papel alumínio, $40 \mathrm{~mL}$ desta solução. Os tubos foram então agitados com a mão e deixados por $30 \mathrm{~min}$. em banho-maria a $90^{\circ} \mathrm{C}\left( \pm 1^{\circ} \mathrm{C}\right)$. Nesta etapa, os tubos permaneceram fechados. Passados 20, 25 e nos exatos 30 minutos os tubos foram agitados com a mão.

Após resfriamento dos frascos, estes foram centrifugados e o sobrenadante filtrado em balão de $50 \mathrm{~mL}$. Em seguida foram adicionados $5 \mathrm{~mL}$ de solução de $\mathrm{NaCl}(0,1 \mathrm{M})$, fez-se a agitação na mão dos fracos, a centrifugação e nova filtragem do sobrenadante. Por fim os balões foram completados com água MiliQ. Nesta fração não foi adicionado ácido nítrico.

Em seguida foi feita a extração do ferro ligado a óxidos cristalino (F4) através da adição de $40 \mathrm{~mL}$ de $\mathrm{HCl}(6 \mathrm{M})$ em cada um dos frascos os quais permaneceram por $24 \mathrm{~h}$ em agitação horizontal a $180 \mathrm{rpm}$. Após estes períodos os frascos foram centrifugados a 3000 rpm por 15 minutos e na sequência filtrou-se a solução sobrenadante para balões de $50 \mathrm{~mL}$. Antes da filtragem da solução garantiu-se que o ambiente encontrava-se arejado, com exaustor ligado. Feito a filtragem adicionou-se $5 \mathrm{~mL}$ da solução de $\mathrm{NaCl}(0,1 \mathrm{M})$ nos frascos, agitou-se os mesmos com a mão, fez-se a centrifugação destes e logo após adicionou-se a solução sobrenadante no mesmo balão com o extrator. Feito a filtragem da solução com $\mathrm{NaCl}$, os balões foram completados com água MiliQ. Não foi adicionado ácido nítrico nesta fração.

Finalizadas todas as extrações, preparou-se 2 curvas de calibração de ferro para a quantificação da concentração de ferro. A Curva-1 foi composta por soluções de 0,25 ; 0,5; 0,75 e $1 \mathrm{mg} / \mathrm{L}$ de ferro enquanto que a segunda, Curva-2, foi preparada a partir das soluções de 1, 2 e 4mg/L de ferro. Os pontos da curva foram preparados a partir de solução inicial de $100 \mathrm{mg} / \mathrm{L}$ preparada por meio da diluição de solução padrão de $1000 \mathrm{mg} / \mathrm{L}$ de ferro (MercK).

A determinação da concentração de ferro nas amostras foi realizada através de espectrofotômetro de absorção atômica por chama (EAA) da Escola Superior de Agricultura "Luiz de Queiros". As Frações 1 e 2 não necessitaram de diluição e foram quantificadas utilizando a Curva-1 de calibração, já a Fração 3 e 4 das amostras do Latossolo Vermelho-Amarelo e do Neossolo Quartzarênico foram diluídas 50 vezes em tubos de ensaio enquanto que as amostras de Latossolo Vermelho foram diluídas 100 vezes. Para a leitura das Frações 3 e 4 utilizou-se a Curva-2. 


\subsection{Mineralogia}

A fim de identificar os minerais presentes nas amostras de solos realizou-se a análise mineralógica da fração argila. Para tanto, foi necessário inicialmente separar $50 \mathrm{~g}$ de TFSA. Além disso, foi necessário remover a matéria orgânica da amostra, conforme método descrito por Anderson (1963).

Transferiu-se a TFSA para um tubo de centrífuga Sorvall de $250 \mathrm{~mL}$ e adicionou-se $50 \mathrm{~mL}$ de $\mathrm{NaClO} \mathrm{pH}$ 9,5. Os tubos foram agitados manualmente para homogeneização da amostra. Em seguida os tubos foram colocados no banho-maria a $80^{\circ} \mathrm{C}$, por 15 minutos. Passados os 30 minutos no banho, os tubos foram centrifugados a uma rotação de $1500 \mathrm{rpm}$, durante 5 minutos. No término da centrifugação fez-se o descarte do sobrenadante. Esta etapa foi repetida 3 vezes para que a amostra ficasse totalmente livre de matéria orgânica.

Após a remoção da fração orgânica, $50 \mathrm{~mL}$ de $\mathrm{NaCl}(0,1 \mathrm{~N})$ foram misturados com as amostras de solo presente nos tubos. Após a homogeneização, centrifugou-se novamente a $1500 \mathrm{rpm}$, por mais 5 minutos. O sobrenadante foi descartado e esta etapa foi repetida duas vezes. Para a remoção do $\mathrm{NaCl}$ foram colocados $25 \mathrm{~mL}$ de água destilada nos tubos e os mesmos foram agitados, na sequência centrifugou-se a $2000 \mathrm{rpm}$ por 10 minutos. Esta etapa é realizada para a dispersão da argila.

Feita a preparação das amostras para obtenção da fração argila total, as amostras foram analisadas num Difratômetro de Raios-X, marca Bruker, modelo D8 Advance da Universidade Federal de São Paulo. As amostras foram dispostas no suporte de amostra de forma a evitar a orientação dos filossilicatos. A amplitude utilizada foi de 2 a $65^{\circ} \theta$, sendo que o passo foi de $0,02^{\circ} \theta$ a uma velocidade de $0,02^{\circ} \theta / \mathrm{seg}$. Esta análise foi realizada tanto para nas amostras antes e após a oxidação por batelada.

\subsection{Oxidação do Solo - Ensaio por Batelada}

Para avaliação do decaimento da massa de persulfato devido à interação do oxidante com o solo foi realizado ensaio de batelada. Para tanto, a TFSA do LV, LVA e NQ foram mantidas em contato com a solução oxidante em frascos de vidro de $500 \mathrm{~mL}$, e ao longo deste período quantificou-se a concentração de persulfato nos reatores. Ensaios de batelada para avaliação do consumo de oxidante pelo solo e por contaminantes orgânicos são amplamente utilizados, sendo que o período de realização varia de acordo com as condições de cada ensaio (LIANG et al., 2008; XU, 2006; CRIMI e TAYLOR, 2007; KILLIAN et al., 2007; LEE et al., 2008; TSAI et al., 2009; TEEL et al., 2009; 
AHMAD et al., 2010; FURMAN et al., 2010; SRA et al., 2010; TEEL et al., 2011; LIANG et al., 2011).

$\mathrm{Xu}$ e Thomson (2009) realizaram teste de bancada por um período de aproximadamente 300 dias para avaliar o consumo do oxidante permanganato pelo solo. Brusseau et al. (2011) também utilizaram o permanganato num ensaio de curto e longo prazo, equivalente a 1 e 21 meses de duração. Neste estudo, os autores verificaram que o teste de curta duração proporcionou uma caracterização representativa em relação ao consumo de oxidante. Desta forma, definiu-se que a duração máxima do presente experimento seria de 120 dias.

Foram utilizados nos ensaios de batelada os três tipos de solo selecionados e previamente preparados. Neste ensaio optou-se por utilizar duas concentrações de solução oxidante diferentes $(1$ e $14 \mathrm{~g} / \mathrm{L})$ as quais foram preparadas pela adição de massa de persulfato de potássio $\left(\mathrm{K}_{2} \mathrm{~S}_{2} \mathrm{O}_{8}\right)$ nos reatores. A concentração de 1 e $14 \mathrm{~g} / \mathrm{L}$ foram adotadas por ser próxima àquelas utilizadas por outros autores bem como por estar próxima às concentrações empregadas em processo de remediação por oxidação química in situ. Com o intuito de avaliar o decaimento do oxidante, na maioria dos estudos, os autores optam por utilizar duas ou mais concentrações diferentes, sendo uma considerada baixa, outra elevada e as demais intermediárias (AHMAD, TEEL \& WATTS, 2010; MERKER, 2010; SRA et. al., 2010). Por exemplo, Sra et al., (2010) utilizaram concentrações de 1 e 20 g/L.

A relação entre a massa de oxidante e massa de solo também é um importante fator a ser considerado durante a definição das condições do experimento assim como a relação entre massa de solo e volume de solução. Os reatores foram montados com $200 \mathrm{~g}$ de solo e $300 \mathrm{~mL}$ de solução, resultando em doses de 1,5 e 21 g $\mathrm{S}_{2} \mathrm{O}_{8} / \mathrm{kg}$ solo para os reatores cuja concentração inicial da solução foram 1 e $14 \mathrm{~g} / \mathrm{L}$, respectivamente, similar à adotada em outros estudos (Sra et al., 2010). O experimento foi realizado em triplicata e os resultados foram calculados a partir da média das concentrações.

Além dos frascos com solo e solução de persulfato foram preparados, também em triplicata, frascos contendo apenas solo e água na mesma proporção (Controle Tipo 1) e frascos contendo apenas $300 \mathrm{~mL}$ de solução oxidante com concentração de 1 e 14g/L (Controle Tipo 2). Estes frascos permaneceram nas mesmas condições que os demais ao longo de todo o período. A partir do Controle Tipo 2 foi possível verificar o decaimento do persulfato por hidrólise e outras reações que resultem em seu consumo.

Para o preparo dos reatores fez-se inicialmente a mistura da massa de $200 \mathrm{~g}$ de TFSA com o $300 \mathrm{~mL}$ de água destilada em frascos de vidro de $500 \mathrm{~mL}$ previamente 
limpos e identificados. Para a completa mistura, os frascos foram agitados com a mão por um período de 5 minutos. Após 24 horas fez-se a adição de 0,4293 e 5,9691g de persulfato de potássio nos reatores para a elevação da concentração inicial para 1g/L (C1) e 14 g/L (C2), respectivamente, seguindo o procedimento adotado por Sra et al., (2010).

A concentração de persulfato foi então monitorada ao longo de aproximadamente 120 dias, sendo que após este período a concentração de persulfato foi elevada novamente para a concentração inicial nos reatores com concentração inicial de $1 \mathrm{~g} / \mathrm{L}$. Durante o ensaio, leituras para quantificação do persulfato foram realizadas periodicamente em triplicata com intervalos iniciais de $3 \mathrm{~h}$ nos dois primeiros dias, passando para cada $5 \mathrm{~h}$ no terceiro dia e uma análise por dia até o $10^{\circ}$ dia. Após este período as análises foram realizadas a cada $42 \mathrm{~h}$ até completar 30 dias e posteriormente o intervalo para determinação da concentração de persulfato nos reatores foi mantida em $68 \mathrm{~h}$.

Todos os reatores foram mantidos a temperatura ambiente e em ausência de luz visando evitar a decomposição do persulfato (CRIMI \& TAYLOR, 2007). Ao longo do experimento os frascos foram agitados periodicamente manualmente assim como eram agitados aproximadamente $1 \mathrm{~h}$ antes da quantificação de persulfato. A quantificação da concentração de persulfato foi feita por espectrofotometria conforme descrito no item 3.6.1.1. Além do persulfato, ao longo dos 15 primeiros dias fez-se o monitoramento do pH e da temperatura da solução.

\subsubsection{Determinação de Persulfato}

\subsubsection{Determinação por Espectrofotometria}

Para determinação da concentração de persulfato nas amostras foi utilizado um espectrofotômetro de absorção atômica UV-VIS da marca Thermo Scientific. A metodologia adotada seguiu o procedimento descrito por Huang et al. (2002). Para obtenção da linha de base, realizou-se a leitura de uma amostra de água destilada. Para leitura das amostras foram misturados em tubos de ensaio $0,1 \mathrm{~mL}$ da amostra com $0,9 \mathrm{~mL}$ de água destilada; $10 \mathrm{~mL}$ de $\mathrm{H}_{2} \mathrm{SO}_{4}(2,5 \mathrm{~N})$ previamente titulado; $0,1 \mathrm{~mL}$ de sulfato ferroso amoniacal $(0,4 \mathrm{~N})$ preparado no dia da leitura. Após homogeneização, as amostras eram mantidas em repouso por 40min em ambiente com ausência de luz e em seguida eram adicionados mais $0,2 \mathrm{~mL}$ de tiocianato de amônio $\left(\mathrm{NH}_{4} \mathrm{SCN}\right)$ a $0,6 \mathrm{~N}$ também preparado no dia da leitura. Feito isso, eram feitas as leituras de absorbância a 454nm.

A curva de calibração do método foi criada e definidos os limites de determinação e quantificação. Foram realizadas ao todo três curvas de calibração para obtenção da 
regressão linear média e o coeficiente de correlação. Para tanto, fez-se a leitura de cinco pontos diferentes preparados a partir de duas soluções estoques de 30g/L (Figura 8). A curva de calibração foi definida entre o intervalo de 200 a $2000 \mathrm{mg} / \mathrm{L}$ de persulfato $\left(\mathrm{R}^{2}=0.99\right)$.

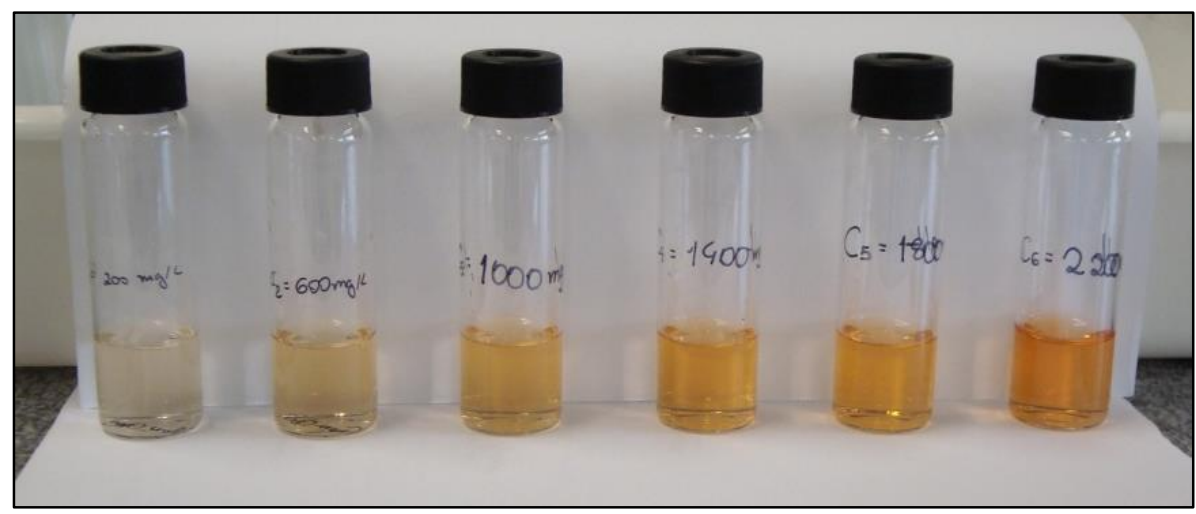

Figura 8 - Padrões da curva de calibração.

Os limites de detecção e quantificação foram obtidos com base no procedimento de orientação do Instituto Nacional de Metrologia, Qualidade e Tecnologia (INMETRO, 2010). O limite de detecção foi então determinado a partir da leitura de cinco brancos os quais foram preparadas com água destilada. Após a obtenção da absorbância dos brancos no comprimento de onda de $454 \mathrm{~nm}$ determinou-se o limite de detecção (LD) considerando um grau de liberdade (t-student) de 99,9\%, a média do resultado das leituras dos brancos (Bm) bem como o desvio padrão (Dpad) (eq. 18).

$$
\mathbf{L D}=[\mathbf{B m}+(\boldsymbol{t} \times \mathbf{D p a d})]
$$

Sendo que,

$t$ : t-student com grau de liberdade de 99,9\%;

O limite de quantificação foi quantificado por meio da soma da média da absorbância dos brancos e cinco desvios padrões. Em todos os dias de leitura, foram feitas também leituras da concentração de persulfato em soluções padrões preparados a partir de duas soluções estoque de $30 \mathrm{~g} / \mathrm{L}$ de persulfato.

\subsubsection{Determinação por Titulação}

Para a validação do método de quantificação de persulfato, foi realizada a determinação da concentração de persulfato nos padrões por meio de titulação. Esse método é baseado na oxidação do íon ferroso pelo persulfato em solução ácida a temperatura ambiente. Um conhecido excesso de íons ferroso é adicionado nas amostras e o residual é titulado com solução de sulfato ferroso padronizado (KODAK, 2003). Para isso, em erlenmeyer de $250 \mathrm{~mL}$ com agitador magnético foram pipetados $5 \mathrm{~mL}$ da amostra 
a ser titulada, $50 \mathrm{~mL}$ de água MiliQ, $15 \mathrm{~mL}$ de $\mathrm{H}_{2} \mathrm{SO}_{4}(7 \mathrm{~N})$ previamente titulado e $10 \mathrm{~mL}$ de $\mathrm{Fe}\left(\mathrm{NH}_{4}\right)_{2}\left(\mathrm{SO}_{4}\right) \cdot 6 \mathrm{H}_{2} \mathrm{O}(0,25 \mathrm{~N})$. Após adição das quantidades citadas fez-se a homogeneização da solução a qual permaneceu em repouso por 3 min. Adicionalmente acrescentou-se 4 gotas de ferroína e fez-se a titulação com solução de sulfato cerato $\left(\mathrm{NH}_{4}\right)_{2} \mathrm{Ce}\left(\mathrm{NO}_{3}\right)_{6}(0,05 \mathrm{~N})$ previamente titulado até a quarta casa decimal. A seguir demonstra-se a equação utilizada para o cálculo da concentração de persulfato.

$$
\mathrm{S}_{2} \mathrm{O}_{8}\left(\frac{\mathrm{g}}{\mathrm{L}}\right)=\frac{(\mathrm{BCOt}-\mathrm{AMt}) \times \mathrm{C} \times \mathrm{PE}}{\mathrm{AM}}
$$

Sendo,

BCOt: volume em mL de sulfato cerato utilizado na titulação do branco;

AMt: volume em mL de sulfato cerato utilizado na titulação da amostra;

AM: volume em mL de amostra a ser titulado;

C: normalidade da solução de sulfato cerato titulado até a quarta casa decimal; e

PE: peso equivalente do persulfato de potássio;

\subsubsection{Avaliação de Interferências}

As partículas finas de solo que permanecem em suspensão na solução podem interferir na quantificação de persulfato, e diferentes procedimentos são relatados na literatura para lidar com isso. Xu (2006) centrifugou por 1 hora a $4000 \mathrm{rpm}$ amostras de solo afim de eliminar a interferência dos coloides para análise de permanganato. Liang et al. (2008) separaram os coloides do solo da solução por meio de 20 min. de centrifugação a 1500 rpm.

Testes de centrifugação com as amostras do LV e do LVA foram realizados, mas os resultados não foram satisfatórios tendo em vista o tempo necessário para sedimentação da fração argila. Nos testes foram misturados $100 \mathrm{~g}$ de solo com $300 \mathrm{e}$ $400 \mathrm{~mL}$ de água em frasco de $500 \mathrm{~mL}$, sendo que após 1 dia, alíquotas de 10, 15 e $20 \mathrm{~mL}$ foram centrifugadas a 10, 20 e $25 \mathrm{~min}$ a $2100 \mathrm{rpm}$.

O método utilizado para eliminar interferências foi realizado a partir da leitura no comprimento de 454nm, das amostras coletadas nos reatores de cada solo com concentração de 1 e 14g/L. Contudo, ao invés de adicionar os reagentes citados no item 3.6.1.1 para obtenção de coloração alaranjada, adicionou-se água na mesma proporção em que foi feita a diluição das amostras utilizadas para determinação de persulfato (Sra et. al., 2010). Os valores de absorbância utilizado para determinação do persulfato foi calculado pela diferença entre as amostras com adição dos reagentes e aquela na qual 
foi adicionado apenas água, ambas lidas no mesmo comprimento de onda. Ressalta-se que as amostras diluídas em água apresentaram valores de absorbância nulo ou negativo.

\subsection{Teste de coluna}

A maioria dos trabalhos relacionados à oxidação química in situ tem sido desenvolvida apenas com teste de batelada (LIANG et al., 2008). Experimentos em coluna permitem avaliar o fluxo unidimensional do fluido em escala pequena e quantificar propriedades hidráulicas do material, como o coeficiente de dispersão, porosidade e condutividade hidráulica, determinadas com um traçador conservativo (LEWIS \& SJÖSTROM, 2010). Testes de coluna também permitem determinar a porosidade do solo. Além das propriedades hidráulicas, por meio de ensaios de oxidação com coluna é possível obter resultados relativos a taxa da reação mais próximos da condição observada em campo (SRA et al., 2010).

Sendo assim, duas colunas preenchidas com LV passaram por uma sequência de ensaios. Inicialmente as colunas foram saturadas a uma vazão de $8 \mathrm{ml} / \mathrm{min}$ e em seguida foi realizado os ensaios com o traçador conservativo. Feito isso, o solo presente nas colunas foi oxidado por meio da injeção de persulfato de potássio ao longo de 30 dias com solução de persulfato de 14 e $9 \mathrm{~g} / \mathrm{L}$ e, na sequência, novos ensaios com traçador conservativo foram realizados para nova determinação das características hidráulicas. $\mathrm{O}$ LV foi o solo selecionado para o experimento pois foi o solo que teve maior interação com o oxidante no experimento por batelada.

\subsubsection{Seleção de Traçadores Conservativos}

Para avaliar a viabilidade de usar alguns compostos inorgânicos como traçadores conservativos (não reativos), realizou-se teste com coluna deformada confeccionada a partir de tubos e conexões em PVC (Figura 9). Na base da coluna foi acrescentado um pedaço de espuma e sobre esta foi acrescentado $2 \mathrm{~cm}$ de esferas de vidro de $2 \mathrm{~mm}$ de diâmetro as quais foram lavadas inicialmente com água destilada. Acima dessa camada adicionou-se mais $2 \mathrm{~cm}$ de areia selecionada ( 1 a $1,5 \mathrm{~cm}$ ) previamente lavada em solução de $\mathrm{HCl}(0,05 \mathrm{M}), \mathrm{NaOH}(0,1 \mathrm{M})$ e água. Em seguida fez-se o preenchimento da coluna com a TFSA de Latossolo Vermelho. Ao todo a espessura de solo na coluna foi de $18 \mathrm{~cm}$. Ao longo do preenchimento a coluna foi sendo compactada por meio de leves golpes na lateral da coluna, a qual ia sendo rotacionada a fim de nivelar as camadas de sólidos na coluna. Por fim, foram adicionados mais $0,75 \mathrm{~cm}$ de areia e esferas de vidro. Por cima desta última camada foi acrescentado um pedaço de espuma a fim de evitar a perda de 
sólidos. A massa de solo acrescentada na coluna foi quantificada, a fim de obter a densidade e porosidade do solo na coluna. Antes de iniciar a injeção do traçador pela a coluna, fez-se a saturação da mesma com água desaerada e com pH ajustado a 6 e condutividade elétrica ajustada a $17 \mu \mathrm{S} / \mathrm{cm}$ a qual passou a ser chamada de água sintética.

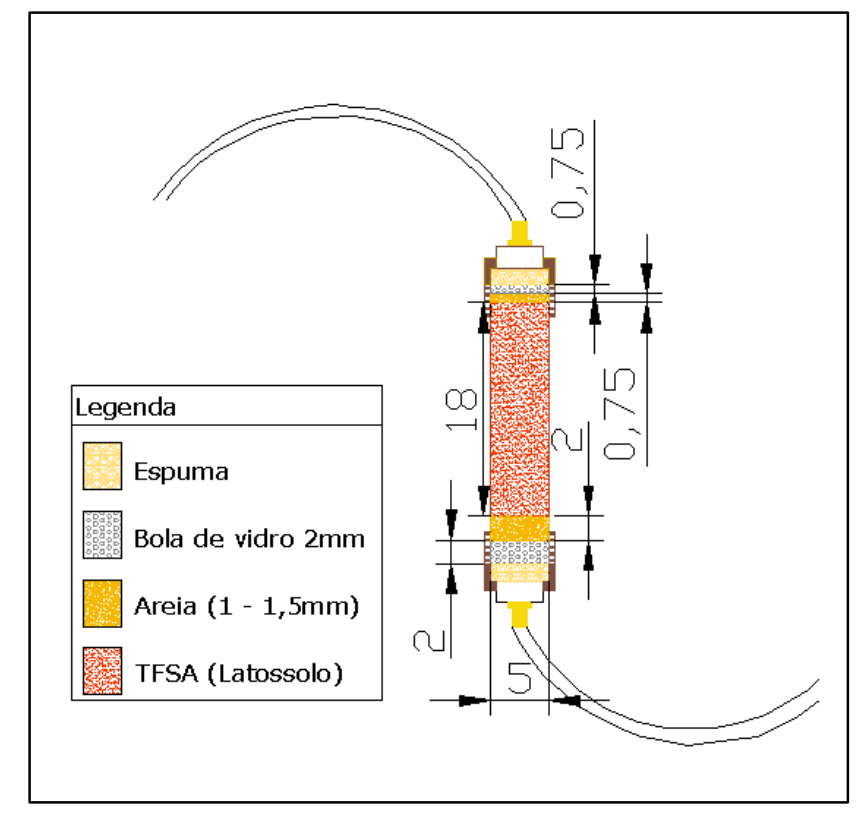

Figura 9 - Dimensões da coluna deformada utilizada para teste do traçador.

Inicialmente foi testada a fluoresceína sódica como traçador. Foi injetado continuamente com fluxo ascendente, durante aproximadamente 4h, uma solução aquosa de $150 \mathrm{mg} / \mathrm{L}$ de fluoresceína. A vazão variou entre 4 a $6 \mathrm{~mL} / \mathrm{min}$ e a injeção ocorreu por diferença de energia potencial, sendo que o gradiente hidráulico foi mantido constante. A quantificação da concentração da fluoresceína na saída da coluna foi realizada por meio de um fluorímetro a $490 \mathrm{~nm}$ (Thermo Scientific QNT BASE) utilizando filtro primário para seleção do comprimento de onda de excitação e secundário para seleção do espectro de emissão, NB 490 e SC 515, respectivamente. Para tanto foi inserida curva de calibração no aparelho com 5 pontos entre 1 a $100 \mathrm{mg} / \mathrm{L}$.

Após os testes com a fluoresceína, foi realizado experimento com o brometo. Para a quantificação da concentração de brometo foi utilizado um eletrodo de íons seletivo da marca Thermo Scientific pH/SE modelo Orion Star A324 capaz de medir o potencial de redução da solução devido à presença de íons de brometo em solução. Para tanto, foi elaborada a curva de calibração a partir da leitura do potencial de redução de 9 padrões preparados por duas soluções estoques de $1000 \mathrm{mg} / \mathrm{L}$ de Brometo $(2,5,25,50,125,250$, 300, 500 e $1000 \mathrm{mg} / \mathrm{L})$. A regressão linear foi elaborada por meio de gráfico monolog, sendo que a escala logarítmica foi mantida no eixo das coordenadas do plano cartesiano. 
A injeção do brometo na coluna foi realizada por diferença de energia potencial de forma continua com fluxo ascendente até que a concentração na saída da coluna fosse a igual àquela injetada. Inicialmente foi injetada uma solução de brometo com $250 \mathrm{mg} / \mathrm{L}$, contudo nesta concentração ocorreu a dispersão da argila. A fim de evitar a dispersão da argila, a concentração de brometo para injeção foi reduzida para $30 \mathrm{mg} / \mathrm{L}$, a vazão média foi de $16,5 \mathrm{~mL} / \mathrm{min}$ e o gradiente hidráulico foi mantido constante.

Para verificação dos compostos como traçadores conservativos, as concentrações medidas foram comparadas a solução analítica de Ogata-Banks eq. (20) (OGATA \& BANKS, 1961 apud DOMENICO \& SCHWARTZ, 1998).

$$
\frac{C(x, t)}{C 0}=\left(\frac{1}{2}\right)\left(\operatorname{erfc} \frac{[(x-v t)]}{\left[2(D t)^{\frac{1}{2}}\right]}\right)
$$

Onde "D" representa o coeficiente de dispersão hidrodinâmica, erfc trata-se de uma função de erro complementar, " $v$ " é a velocidade linear da água a qual é identificada pela velocidade do traçador, " $x$ " é o comprimento da coluna de solo e " $t$ " é o tempo. $\mathrm{O}$ coeficiente de dispersão hidrodinâmica (D) é a soma da dispersão mecânica e a difusão (eq. 21).

$$
\boldsymbol{D}=\boldsymbol{D}^{\prime}+\boldsymbol{D}_{\boldsymbol{d}}^{*}
$$

A dispersão mecânica pode ser escrita como produto entre a dispersividade $(\alpha)$ e a velocidade (v). Sendo assim, a Equação 21 pode ser escrita da seguinte maneira eq. (22):

$$
D=\alpha v+D_{d}^{*}
$$

$D$ : Dispersão hidrodinâmica;

$D^{*}{ }_{\mathrm{d}}$ : Coeficiente de difusão molecular efetiva;

$\alpha$ : dispersividade;

$v$ : velocidade.

Assim que a concentração de saída igualou-se a de entrada, interrompeu-se a injeção da solução de $30 \mathrm{mg} / \mathrm{L}$ de brometo e foi iniciada a injeção de água sintética a fim de monitorar o decaimento da concentração de brometo na saída da coluna. As condições para a injeção da água foram semelhantes às utilizadas para a injeção do brometo.

\subsection{Coluna Indeformada}

\subsubsection{Montagem e Preparação das Colunas}

Para a coleta das colunas, inicialmente foi realizado o corte no talude até a profundidade desejada para a realização da amostragem a qual foi equivalente a $1 \mathrm{~m}$; em 
seguida foi investigada a presença de raízes, cupins, formigas e outros nas imediações do ponto de amostragem. Feito isso, fez-se o aplainamento na superfície do corte do talude. Tomou-se o cuidado em realizar a amostragem em período com ausência de precipitação já que isso dificultaria a amostragem.

Um cilindro de aço com umas das extremidades cortantes foi cravado nesse corte já aplainado. Para isso, uma tábua de madeira foi colocada sobre a coluna de aço onde com um martelo emborrachado golpes foram dados até a plena cravação da coluna ( $\approx 15$ golpes). Para a remoção da coluna do perfil de solo fez-se o corte no solo com faca e espátulas até que todo o bloco de solo fosse retirado. O bloco foi levado ao laboratório para preparação.

Para a obtenção da coluna indeformada foram necessárias algumas tentativas com dimensões de coluna diferentes e com métodos de amostragem diferentes a fim de evitar a compactação do solo. Na primeira tentativa, a relação entre a altura e o diâmetro da coluna foi de $4,5(45 \mathrm{~cm} \times 10 \mathrm{~cm})$ e a compactação da coluna foi de aproximadamente $55 \%$, considerado inaceitável. A segunda coluna teve sua altura reduzida para $30 \mathrm{~cm}$ e o mesmo diâmetro foi mantido, contudo foi observado ainda $45 \%$ de compactação dos sólidos. A terceira coluna cuja relação altura e diâmetro foi reduzida para 2 $(20 \mathrm{~cm} \times 10 \mathrm{~cm})$ mostrou-se mais satisfatória para a realização do ensaio já que apresentou compactação de aproximadamente $20 \%$. Todas as colunas utilizadas eram constituídas de aço com espessura de aproximadamente $2 \mathrm{~mm}$ e um dos lados cortantes.

Após a definição das dimensões da coluna a ser utilizada, ou seja, $20 \mathrm{~cm}$ de altura por $10 \mathrm{~cm}$ de diâmetro, duas colunas (Coluna 1 e Coluna 2) foram preenchidas com Latossolo Vermelho no mesmo perfil utilizado para coleta de amostra deformada deste solo (Rodovia Luiz de Queiroz, Piracicaba/SP) na profundidade de $1 \mathrm{~m}$.

Apesar das colunas confeccionadas em aço terem $20 \mathrm{~cm}$, o solo não preencheu totalmente as colunas devido a compactação ocasionada. Aproximadamente, a Coluna 1 e 2 foram preenchidas respectivamente por 11,8 e 13,6 cm de solo em seu interior.

Retirado o bloco de solo fez-se a limpeza nas laterais da coluna tomando o cuidado para não quebrar os agregados dentro da coluna indeformada. A coluna foi levada até o laboratório ainda com uma camada de solo adicional na sua base, a qual foi cuidadosamente cortada no momento da montagem do sistema de fluxo pela coluna.

Após preenchimento do topo, fez-se o corte de $2 \mathrm{~cm}$ de solo adicional na base das colunas para a adição do material filtrante composto por de areia muito grossa limpa e 
selecionada. Sobre a camada de areia foram acrescentadas uma fina camada de esferas de vidro de $2 \mathrm{~mm}$ (Figura 10).

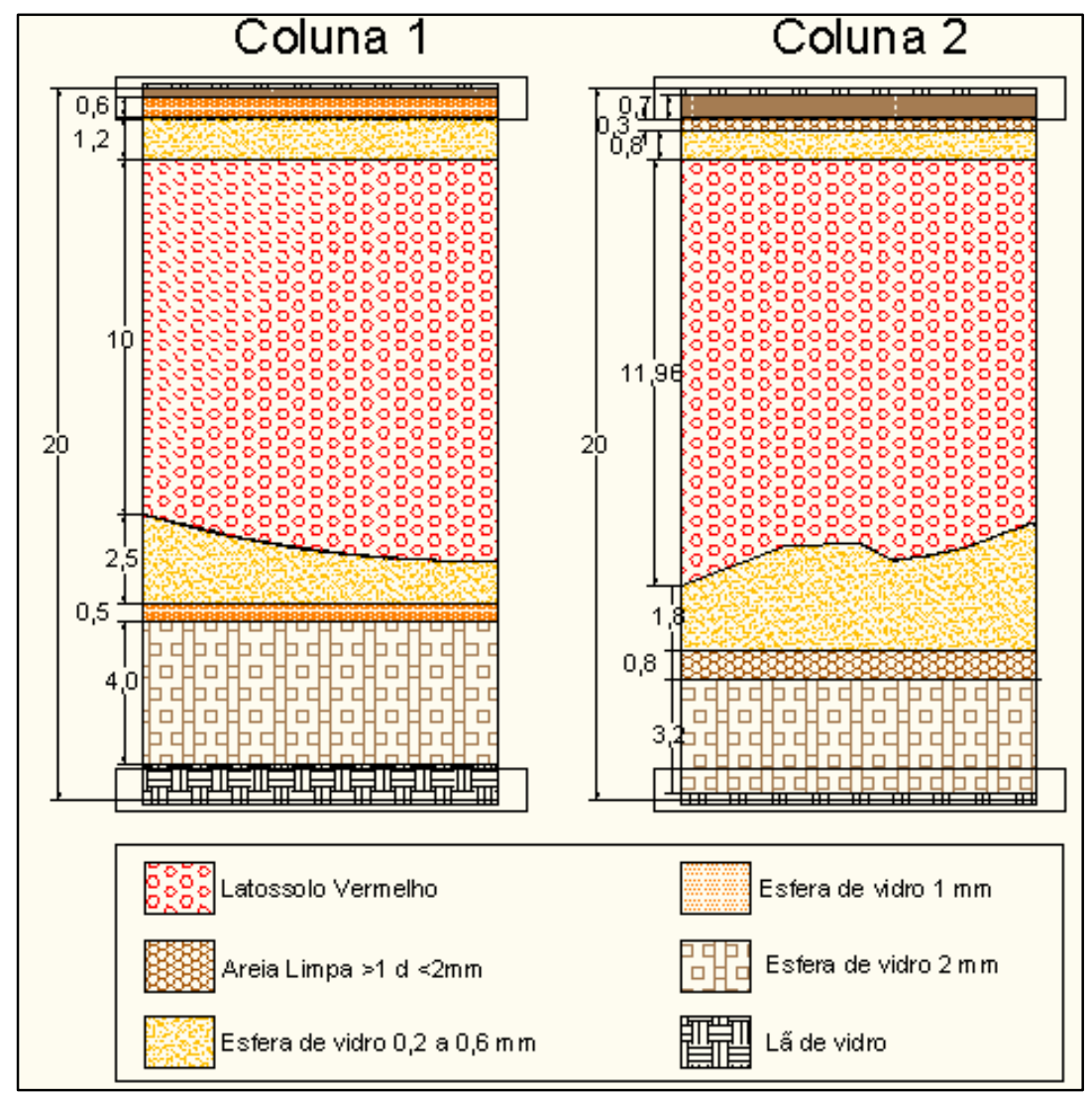

Figura 10 - Dimensões da Coluna 1 e 2 com amostras indeformadas em seu interior

Para evitar a retenção de bolhas de ar nos poros da coluna durante a saturação, injetou-se gás carbônico durante $15 \mathrm{~min}$ a uma pressão de 0,5 psi $\left(3447 \mathrm{~N} / \mathrm{m}^{2}\right)$. O gás carbônico por ser solúvel em água permite que os poros do solo sejam totalmente preenchidos pela água no momento da saturação da coluna. Após o preenchimento dos poros por gás carbônico, foi realizada então a injeção de água sintética desaerada a uma vazão de $9,0 \mathrm{~mL} / \mathrm{h}$.

Estudos mostram que o uso de água destilada para ensaio com coluna pode interferir na condutividade hidráulica e para evitar essa interferência deve-se ajustar os valores da condutividade elétrica e do $\mathrm{pH}$ preparando assim água sintética com valores destes parâmetros equivalentes ao da água subterrânea local (RAYMOND et al., 2004).

Sendo assim, inicialmente fez-se a coleta da água subterrânea próximo ao ponto de amostragem do solo afim de avaliar a concentração dos sais nela presente bem como a condutividade elétrica e $\mathrm{pH}$. A correção da condutividade elétrica foi então feita para $17 \mu \mathrm{S} / \mathrm{cm}$, por meio da adição de 5,5mg de $\mathrm{KCl}$ para cada $1 \mathrm{~L}$ de água destilada. Já para a correção do $\mathrm{pH}$ para 6,0, valor do $\mathrm{pH}$ da água subterrânea, foram adicionados $2 \mathrm{mg}$ de 
$\mathrm{NaHCO}_{3}$ para cada $1 \mathrm{~L}$ de água destilada. A saturação da coluna foi então realizada através de fluxo ascendente.

O ensaio foi realizado com fluxo contínuo ascendente tanto para a saturação da coluna quanto nos demais ensaios realizados na sequência. A vazão de injeção tanto para o teste com o traçador conservativo quanto para a oxidação da coluna foi de $30 \mathrm{~mL} / \mathrm{h}$ por meio da utilização de bomba peristáltica digital Masterflex L/S Standard na Coluna 2 e uma Watson Marlow na Coluna 1. Foram utilizadas conexões Swagelok e tubulações de Teflon para montagem das colunas, sendo que uma conexão tipo "T" foi instalada antes da entrada inferior da coluna, seguida por uma conexão de duas vias. Na parte superior da coluna, ou seja, na saída da coluna foi instalada uma conexão de três vias. Todas as soluções injetadas nas colunas foram desareadas a fim de evitar retenção de bolhas de ar pela coluna. Para tanto foi utilizado o desaerador Humbold HM-4187A.

Foi ainda acoplado na saída de cada uma das colunas uma célula de fluxo com $15 \mathrm{~mL}$ confeccionada em acrílico, onde eletrodos foram inseridos durante os ensaios para determinação em fluxo contínuo da concentração de brometo, determinação do pH, Eh e temperatura na saída da coluna. A Figura 11 ilustra o início da instalação das conexões.

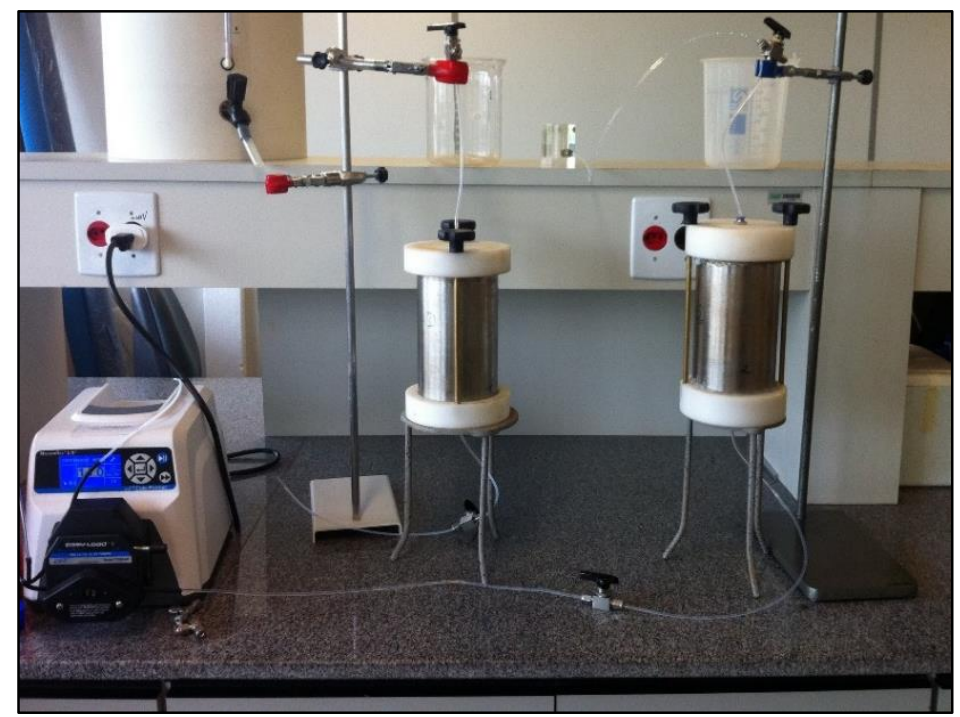

Figura 11 - Colunas Indeformadas, Coluna 1 (esquerda) e a Coluna 2 (direita).

\subsubsection{Teste com Traçador Conservativo}

Os ensaios com o traçador conservativo foram realizados logo após a montagem da coluna e após a oxidação, para a determinação do coeficiente de dispersão hidrodinâmica, porosidade e velocidade média da água subterrânea. Para tanto foi injetado o traçador brometo numa concentração de $30 \pm 2 \mathrm{mg} / \mathrm{L}$ a uma vazão de $30 \mathrm{~mL} / \mathrm{h}$ 
( $\pm 2 \mathrm{~mL} / \mathrm{h})$. O volume de solução de brometo injetados nas colunas para a realização do ensaio foi de aproximadamente 1,5L.

Para a quantificação da concentração de brometo foi utilizado um eletrodo de íons seletivo da marca Thermo Scientific pH/SE modelo Orion Star A324 o qual permaneceu inserido na célula de fluxo durante todo o experimento. A curva de calibração foi elaborada a partir de 8 padrões $(2,5,25,50,125,250,300$ e $500 \mathrm{mg} / \mathrm{L})$ preparados por solução padrão de $1000 \mathrm{mg} / \mathrm{L}$ de Brometo, sendo o valor de $\mathrm{R}^{2}$ de 0,999 . A regressão linear foi elaborada por meio de gráfico monolog, sendo que a escala logarítmica foi mantida no eixo da concentração $(\mathrm{mg} / \mathrm{L})$.

\subsubsection{Oxidação das colunas e parâmetros monitorados ao longo da oxidação.}

A oxidação das colunas foi feita com a injeção de persulfato de potássio por 30 dias, primeiro na Coluna 2 e em seguida na Coluna 1. A concentração de persulfato das soluções injetadas nas colunas indeformadas foram 14g/L e 9,0 g/L, na Coluna 1 e 2, respectivamente. A concentração inicial das soluções variou $\pm 1 \mathrm{~g} / \mathrm{L}$. Para quantificação das concentrações foi realizada a titulação das soluções estoques (item 3.6.1.2).

A relação entre massa de persulfato e massa de solo foi equivalente a 108 e 70, para a Coluna 1 e 2, respectivamente. Para controle da concentração da solução de persulfato injetada nas colunas foram realizadas leituras ao longo do período de oxidação. As concentrações de persulfato na saída das colunas foram monitoradas por espectrofotometria (item 3.6.1.1). Considerando o modelo de decaimento observado no ensaio de batelada, ou seja, decaimento de primeira ordem (eq. 23), foi possível calcular o valor da constante da taxa da reação (eq. 26).

$$
\begin{aligned}
& \frac{d C}{d t}=-k \cdot C^{1} \\
& \int_{C 0}^{C} \frac{d C}{C}=-k \int_{0}^{t} \cdot d t \\
& \ln \frac{C}{C 0}=-k t \\
& -k=\frac{\left(\ln \frac{C}{C 0}\right)}{t}
\end{aligned}
$$

Considerando que,

$\frac{d C}{d t}$ : taxa da reação;

$k$ : constante da taxa de reação;

$C$ : concentração de persulfato no tempo t;

$\mathrm{C} 0$ : concentração inicial de persulfato;

1: ordem da reação; 
Desta forma, considerando o comprimento do deslocamento da frente de fluxo (comprimento da coluna) e a velocidade média do fluxo calculada através do breakthrough do brometo já que esse é conservativo foi possível calcular o tempo de viagem da frente eq. (27).

$$
t_{v}=\frac{x}{v}
$$

Sendo,

$t_{v}$ : tempo de viagem da frente de fluxo;

$x$ : deslocamento da frente de fluxo;

$v$ : velocidade média da frente de fluxo conservativa (breakthrough brometo).

Além da concentração de persulfato na saída da coluna, monitorou-se também o $\mathrm{pH}$, a temperatura e o Eh da solução na saída da coluna em intervalos de 1 hora por meio do eletrodo multi-parâmetro Thermo Scientific Orion Star A324, o qual permaneceu acoplado a célula de fluxo.

Além destes parâmetros aferidos continuamente, determinou-se ao longo do teste a concentração de Ferro solúvel e Alumínio na saída da Coluna 1. A determinação do ferro foi realizada por espectrofotometria, sendo que o complexo de ferro (II) laranja-avermelhado foi medido em 515 nm (JEFFERY, 1989). Para a determinação do ferro utilizou-se o método da 1,10-Fenantrolina (JEFFERY, 1989) no qual o ferro (II) reage com a 1,10-fenantrolina formando um complexo de cor vermelho-alaranjado $\left[\left(\mathrm{C}_{12} \mathrm{H}_{8} \mathrm{~N}_{2}\right)_{3} \mathrm{Fe}\right]^{2+}$. Para determinação da quantificação da concentração de ferro (II) foi construída curva de calibração a partir das concentrações de 0, 2, 4, 6, 8 e 10ppm, a correlação obtida foi equivalente a 0,999. A intensidade da cor independe da acidez entre valores de pH 2 a 9 e é estável por longos períodos.

Para a determinação da concentração de Alumínio adotou-se a metodologia proposta por Raij et al., (2001). Em um erlenmeyer, uma amostra de $25 \mathrm{~mL}$ foi misturada com 3 gotas de azul de bromotimol. Esta solução foi então titulada com solução de $\mathrm{NaOH}$ 0,025mol/L até a viragem para a cor azul eq. (28). Além da análise da concentração de alumínio na saída da coluna, determinou-se a concentração de alumínio na entrada da coluna afim de obter o volume da titulação referente ao branco.

$$
A l^{3+}\left(\frac{g}{L}\right)=\frac{[\operatorname{Vamostra}(\mathrm{L})-\operatorname{Vbranco}(\mathrm{L})]}{0,025(L)} \times \mathrm{C}(\mathrm{NaOH})\left(\frac{\mathrm{mol}}{\mathrm{L}}\right) \times \mathrm{PM}\left(\frac{\mathrm{g}}{\mathrm{mol}}\right)
$$

Sendo,

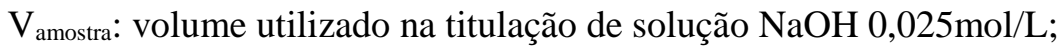

$\mathrm{V}_{\text {branco: }}$ : Volume utilizado na titulação do branco;

0,025: alíquota de amostra ou branco;

$\mathrm{C}(\mathrm{NaOH})$ : concentração da solução utilizada na titulação

PM: peso molar. 


\section{RESULTADOS E DISCUSSÃO}

\subsection{Caracterização das Amostras em campo}

São apresentados os resultados relativos à caracterização em campo das amostras selecionadas e coletadas para a pesquisa. A Figura 12 demonstra a divisão dos horizontes dos perfis pedológico observados em campo. A descrição pedológica completa dos três tipos de solo é apresentada no Anexo 01.

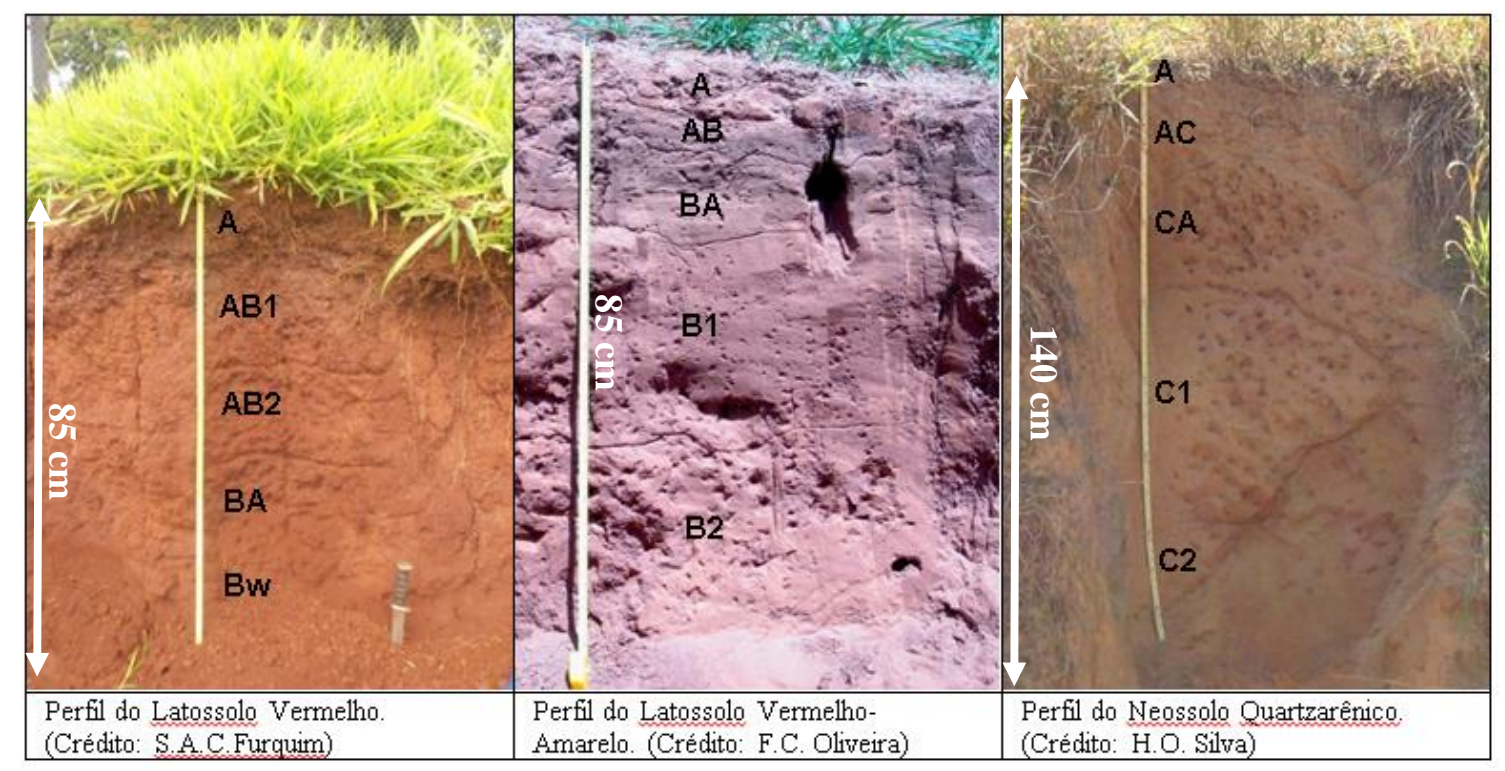

Figura 12 - Divisão dos Horizontes do perfil do LV, LVA e NQ.

\subsubsection{Latossolo Vermelho}

O perfil do Latossolo Vermelho apresentou cinco horizontes, o Horizonte A, AB1, $\mathrm{AB} 2$, BA e Bw consecutivamente, sendo que seus sub horizontes apresentaram pouca diferenciação. A amostra para o desenvolvimento da pesquisa foi coletada no Horizonte Bw, ou seja, no horizonte de diagnóstico. Neste horizonte a cor seca foi 2,5YR 4/4, sendo que a coloração é decorrente da quantidade de matéria orgânica e do tipo de óxido de ferro presente no solo. $\mathrm{O}$ valor observado indica a predominância de hematita em relação à geothita. A textura é muito argilosa, o tipo de estrutura, ou seja, o arranjo dos grãos observado neste horizonte foi microagregados pequenos, grau forte de agregação, consistência macia (seca) e plástica quando úmido. A forte estrutura granular observada no Latossolo ocorre devido a sua composição mineralógica, a qual é composta basicamente por óxidos (KER, 1997).

Destaca-se a ocorrência de carvão natural milimétrico a centimétrico a partir do Horizonte AB. 


\subsubsection{Latossolo Vermelho Amarelo}

No perfil do LVA foi possível distinguir três horizontes diferentes, sendo eles: Horizonte A antropizado (Ap), Horizonte AB e o Horizonte B o qual foi amostrado e possui cor seca 5YR 3/4. Diferentemente do LV, sua textura é média, estrutura granular forte e pequena, macio quando seco e muito friável quando úmido, não é pegajoso e possui plasticidade quando molhado, cerosidade ausente e transição clara.

\subsubsection{Neossolo Quartzarênico}

O perfil do Neossolo Quartzarênico foi descrito na Estação Experimental de Itirapina São Carlos onde foi possível diferenciar cinco tipos de horizontes. Neste solo não é observada a presença do Horizonte B com acumulo de minerais, mas sim a presença do Horizonte C (camada mineral de material inconsolidado), ou seja, camada pouco afetada por processos pedogenéticos. O Horizonte $\mathrm{C} 2$, onde foi feita a coleta das amostras, possui profundidade maior $137 \mathrm{~cm}$, textura arenosa, cor seca 7,5YR 5/6, sem estrutura com grãos simples, não possui plasticidade e não é pegajoso. Essas características são bastante distintas dos solos anteriores, devido a diferença na textura.

\subsection{Caracterização Geológica e Geomorfológica}

\subsubsection{Latossolos}

De acordo com o mapa geológico do estado de São Paulo da CPRM (2011) o local de coleta do Latossolo Vermelho e Vermelho Amarelo encontram-se no contato entre a Formação Serra Geral basicamente composta por basalto e diábasio além de camadas de arenito da Formação Irati pertencente ao Grupo Passa Dois, esta formação é formada por argilito e siltito em sua base e na porção superior por argilito e folhelho, e da Formação Tatuí composta basicamente por rochas sedimentares como siltito, siltito arenoso de cor cinza, além de arenito fino quartzoso. O local de coleta das amostras do Latossolo Vermelho Amarelo encontra-se sobre esta última Formação.

As amostras de Latossolo Vermelho utilizadas nesta pesquisa são provenientes de diques de diabásio. A identificação do material parental foi confirmada através da identificação de fragmento rochoso (Figura 13) e inspeção de perfil pedológico próximo ao ponto de amostragem (Figura 14). 


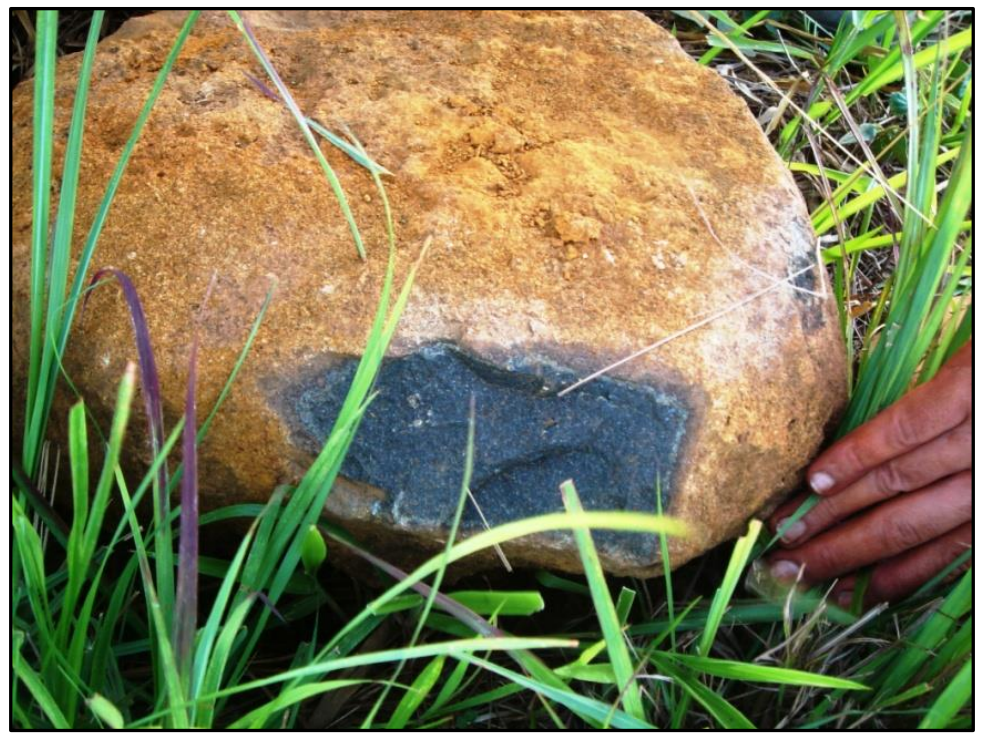

Figura 13 - Fragmento de Diabasio próximo do ponto de coleta do LV.

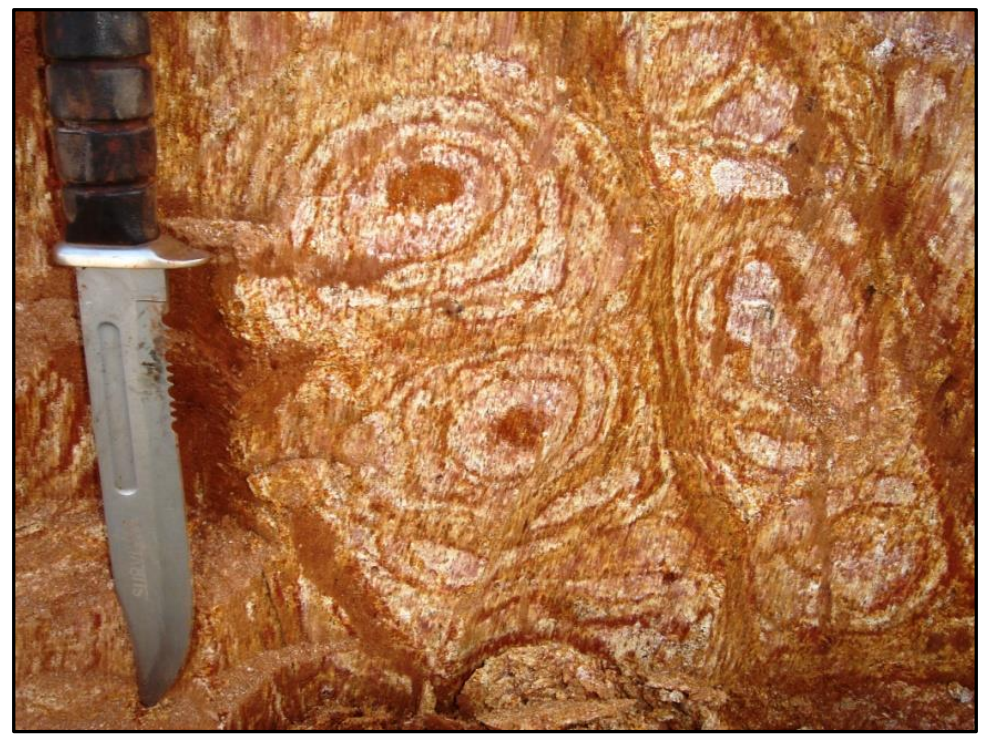

Figura 14 - Horizonte C do Latossolo Vermelho proveniente do Diabasio.

O diabásio assim como o basalto é uma rocha ígnea, sendo que o basalto possui granulação fina e o diabásio granulação mais grossa. Contudo, ressalta-se que a rocha parental é apenas um dos fatores da formação dos solos (BREEMEN \& BUURMAN, 2002 apud PEDRON, 2007). A composição mineralógica de um solo é resultado dos fatores e processos pedogenéticos atuantes (JENNY, 1941; FANNING \& FANNING, 1989; BUOL ET AL., 1997; BREEMEN \& BUURMAN, 2002 apud PEDRON, 2007).

A formação de circunferências no solo conforme apresentado na (Figura 14) devese ao acumulo de óxidos de ferro naquela região. O depósito de ferro em circunferências dá indícios que a rocha parental trata-se de uma rocha ígnea, neste caso decorrente do Diabasio. 
Quanto ao relevo, cita-se que este interfere na dinâmica do fluxo da água, na radiação e temperatura. Segundo Kondo (2002), em ambientes pouco movimentados, quase toda a água pluvial é capaz de infiltrar no solo já que praticamente não ocorre escoamento superficial o que favorece consequentemente a formação de solos profundos como o Latossolo. O relevo da região onde se coletou amostras de Latossolo é composto por colinas amplas com topo aplainado favoráveis para o desenvolvimento de solos profundos. As colinas observadas são levemente convexas com altitude entre 600 a 650 m. A Figura 15 ilustra o relevo nos arredores do ponto de amostragem do LV.

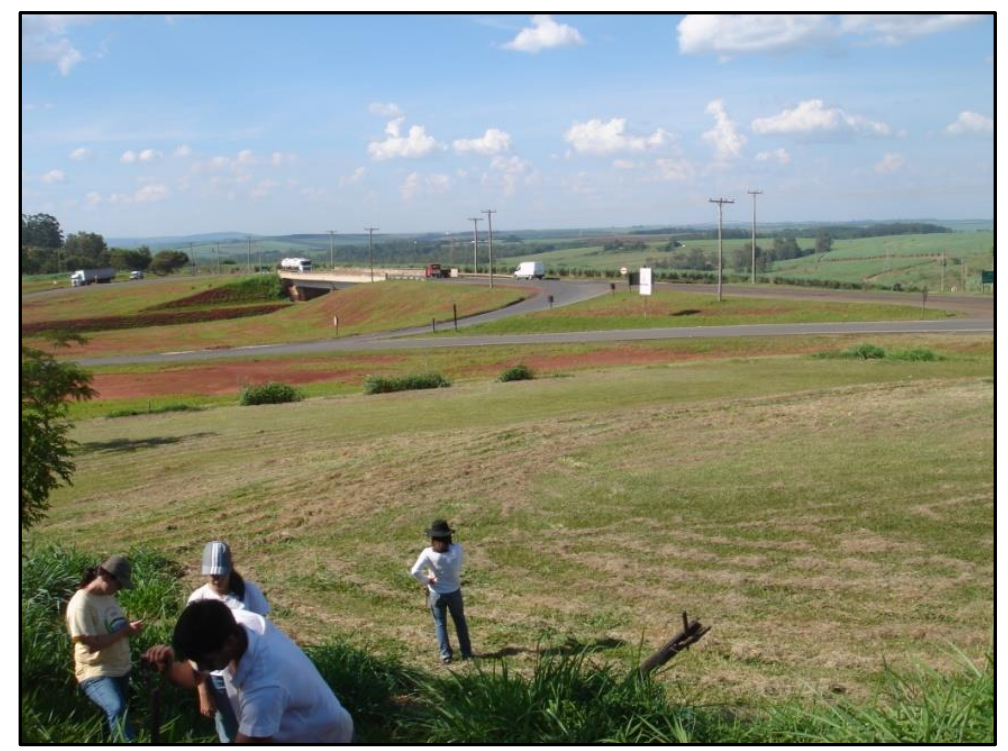

Figura 15 - Vista do ponto de coleta do Latossolo vermelho.

\subsubsection{Neossolo Quartzarênico}

São Carlos está inserido na Bacia Hidrográfica do Mogi Guaçu dentro do Planalto sobre a Formação Botucatu onde são observados afloramentos desta formação. Esta formação é constituída por rochas sedimentares de arenitos avermelhados com areia média a grossa e muito fina a fina com grãos arredondados na fração grossa e subangulares a arredondados na fração fina favorecendo a formação dos Neossolos.

Em relevos acidentados onde o escoamento superficial é acentuado e a estabilidade do talude é dificultada, verifica-se tendência da ocorrência de solos rasos poucos desenvolvidos. Contudo, a região de São Carlos onde foi coletado o Neossolo encontra-se sobre o Planalto Ocidental, onde o relevo no geral é levemente ondulado com predomínio de colinas amplas e baixas e, portanto, favorável para o desenvolvimento do Neossolo. Além disso, outros fatores como resistência do material de origem, clima e tempo foram favoráveis para a formação do Neossolo. 
4.3 Análises Físicas

\subsection{1 Área Específica e grau de floculação}

Apesar de tanto o LV quanto o LVA pertencerem à mesma ordem de solo, texturas diferentes para estas subordens foram observadas de acordo com os resultados dos ensaios granulométricos das amostras coletadas, obtidos por Silva (2014) e Bossi (2014). Nota-se que o LV apresenta 68,5\% de argila enquanto que o LVA apenas 23,4\% correspondente a esta fração. Já o NQ apresenta predominância na fração arenosa, com mais da metade composto por areia fina e muito fina (Tabela 9).

De acordo com a Embrapa (2009), a relação entre silte e argila auxilia a interpretação quanto ao estágio de intemperismo do solo de regiões de clima tropical. Quanto menor for à relação silte-argila, maior o grau de intemperismo sendo que, para solos com textura média, valores inferiores a 0,7 indicam alto grau de intemperização e para solos com textura argilosa este índice é igual a 0,6. Para o LVA, cuja textura é média, e para o LV, cuja textura é muito argilosa, a relação silte-argila foi igual a 0,1 para ambos os solos. Isso indica estágio avançado de desenvolvimento para ambos Latossolos.

A superfície especifica das amostras de solo LVA, LV e NQ foram respectivamente equivalentes a 14,743 $\mathrm{m}^{2} / \mathrm{g} ; 51,343 \mathrm{~m}^{2} / \mathrm{g} ; 6,201 \mathrm{~m}^{2} / \mathrm{g}$. Avaliando o teor de argila nas amostras bem como a área de superfície específica delas ressalta-se que as amostras de solo LV tendem a apresentar maior interação com o oxidante já que conforme observado por Ahmad et al. (2010) e Liu et al. (2014), a área de contato da matriz sólida e o oxidante é diretamente proporcional à constante da taxa da reação.

O grau de floculação das amostras analisadas antes do teste de oxidação apresentados na Tabela 13 mostra que tanto o Latossolo Vermelho quanto o Latossolo Vermelho-Amarelo possuem a fração argila quase que 100\% floculada. O elevado grau de floculação das partículas de argila bem como o elevado teor de argila confere comportamento típico de grãos de areia para o Latossolo Vermelho. No NQ, apesar do grau de floculação também alcançar valores próximo de 100\%, o teor de argila é inferior.

Levando em consideração a porcentagem da fração argila nas amostras verifica-se que aproximadamente 67; 23 e 9\% respectivamente do solo LV, LVA e NQ encontram-se floculados. 
Tabela 13 - Porcentagem das frações de areia, silte e argila medidos por meio do método de dispersão total e através do método de dispersão natural.

\begin{tabular}{ccccc}
\hline Solo & Ensaio & Areia \% & Silte \% & Argila \% \\
\hline \multirow{3}{*}{ LVA/ 0,7-0,85m } & Dispersão total & 73,90 & 2,70 & 23,40 \\
\cline { 2 - 5 } & Dispersão natural & - & 3,15 & 0,20 \\
\cline { 2 - 5 } & Grau de floculação & & $\mathbf{9 9 , 1 5}$ & \\
\hline \multirow{3}{*}{ LV/ $>0,85 \mathrm{~m}$} & Dispersão total & 22,60 & 8,90 & 68,50 \\
\cline { 2 - 5 } & Dispersão natural & - & $1,85 \%$ & $1,20 \%$ \\
\cline { 2 - 5 } & Grau de floculação & $\mathbf{9 8 , 2 5}$ & \\
\hline \multirow{3}{*}{ NQ/ >1,37m } & Dispersão total & 88 & 3,30 & 8,70 \\
\cline { 2 - 5 } & Dispersão natural & - & 1,45 & 0,25 \\
\cline { 2 - 5 } & Grau de floculação & \multicolumn{3}{|c|}{$\mathbf{9 7 3}$} \\
\hline
\end{tabular}

\subsubsection{Densidade de Partículas, Densidade Aparente, Porosidade Total e Umidade}

A Tabela 14 possui os resultados relativos à densidade de partículas das amostras, determinadas antes da oxidação dos solos. O solo que apresentou maior densidade foi o $\operatorname{LV}\left(2,82 \mathrm{~g} / \mathrm{cm}^{3}\right)$, enquanto que o LVA e o NQ detiveram respectivamente $2,75 \mathrm{e}$ $2,77 \mathrm{~g} / \mathrm{cm}^{3}$. Os maiores valores observados para os Latossolo Vermelho podem estar relacionados à maior presença de óxido de ferro na matriz sólida, conferindo maior densidade para esta amostra.

Tabela 14 - Resultados da densidade de partículas das amostras de TFSA dos solos LV, LVA e NQ.

\begin{tabular}{cccc}
\hline \multirow{2}{*}{ Réplicas } & \multicolumn{3}{c}{ Densidade partículas $(\mathrm{g} / \mathrm{cm} 3)$} \\
\cline { 2 - 4 } & 2,86 & LVA & NQ \\
\hline 1 & 2,86 & 2,74 & 2,78 \\
\hline 2 & 2,74 & 2,78 & 2,74 \\
\hline 3 & $\mathbf{2 , 8 2}$ & 2,74 & 2,78 \\
\hline Média & $\mathbf{1 0 , 0 7}$ & $\mathbf{2 , 7 5}$ & $\mathbf{2 , 7 7}$ \\
\hline Desvio & $\mathbf{0 0 , 0 2}$ & $\mathbf{\pm 0 , 0 2}$ \\
\hline
\end{tabular}

A densidade aparente do solo foi determinada apenas para o Latossolo Vermelho já que este foi o solo selecionado para avaliação das propriedades hidráulicas já que, devido suas características, provavelmente este solo é o que apresentará maior tendência de interação com o oxidante persulfato em relação aos demais amostrados. A partir da média aritmética das triplicatas verifica-se que a densidade aparente do Latossolo Vermelho coletado com o anel volumétrico a $1 \mathrm{~m}$ de profundidade é igual a $1,08 \mathrm{~g} / \mathrm{cm}^{3}$ (Tabela 15). O LV também possui porosidade elevada, provavelmente devido ao alto teor de argila e elevado índice de agregação dos grãos. 
Tabela 15 - Densidade aparente das amostras indeformadas coletadas com anel volumétrico.

\begin{tabular}{cccccc}
\hline Parâmetros & Anel 1.1 & Anel 1.2 & Anel 1.3 & Média & Desvio \\
\hline Massa de solo seco $(\mathrm{g})$ & 100,50 & 112,40 & 105,12 & 106,01 & - \\
\hline Volume do anel $\left(\mathrm{cm}^{3}\right)$ & \multicolumn{5}{c}{98,17} \\
\hline Densidade aparente $\left(\mathbf{g} / \mathbf{c m}^{\mathbf{3}}\right)$ & $\mathbf{1 , 0 2}$ & $\mathbf{1 , 1 4}$ & $\mathbf{1 , 0 7}$ & $\mathbf{1 , 0 8}$ & $\mathbf{\mathbf { 0 0 , 0 6 }}$ \\
\hline Massa de solo úmido & 156,79 & 173,14 & 237,65 & 189,19 & - \\
\hline Massa de água & 56,29 & 60,74 & 132,53 & 83,19 & - \\
\hline Umidade $(\%)$ & $35,90 \%$ & $35,08 \%$ & $55,77 \%$ & $42,25 \%$ & $\pm 0,12$ \\
\hline Densidade partículas $\left(\mathrm{g} / \mathrm{cm}^{3}\right)$ & 2,82 & 2,82 & 2,82 & 2,82 & - \\
\hline Volume de sólidos $\left(\mathrm{cm}^{3}\right)$ & 35,66 & 39,89 & 37,30 & 37,62 & - \\
\hline Volume de poros $\left(\mathrm{cm}^{3}\right)$ & 62,51 & 58,29 & 60,87 & 60,56 & - \\
\hline Porosidade $(\mathbf{\%})$ & $\mathbf{6 3 , 6 7}$ & $\mathbf{5 9 , 3 7}$ & $\mathbf{6 2 , 0 0}$ & $\mathbf{6 1 , 6 8}$ & $\mathbf{\pm 2 , 1 7}$ \\
\hline
\end{tabular}

\subsubsection{Condutividade Hidráulica}

As amostras de solo LV apresentaram valores de condutividade hidráulica elevados (Tabela 16) e semelhantes a condutividade de grãos de areia apresentadas por Appelo \& Postma (2005). Assim como a porosidade, a condutividade hidráulica acentuada também é atribuída a presença de agregados de grãos de argila.

As amostras coletadas no dia 17/04/2013 detiveram condutividade hidráulica variando em até uma ordem de grandeza, apesar de estas terem sido coletadas em profundidades com no máximo $20 \mathrm{~cm}$ de diferença. Se comparadas com as amostras coletadas em 01/03/2013, verifica-se que a diferença entre os valores foi de até duas ordens de grandeza. Desta forma, apesar de considerados como solos homogêneos em termos da fração granulométrica (DEMATTE, 1996), verifica-se heterogeneidade em relação à condutividade hidráulica deste solo ainda que em variações centimétricas da profundidade e posição horizontal. Os valores menores obtidos no dia 17/04/2013 podem ser resultados de maior compactação das amostras durante a coleta, uma vez que foram coletadas em período com maior ocorrência de chuvas, e, portanto, com o solo com maior umidade.

Os resultados de condutividade hidráulica das amostras submetidas a testes preliminares de oxidação são apresentados e discutidos no Item 4.7. 
Tabela 16 - Resultados da condutividade hidráulica média das 11 amostras indeformada coletadas com anel volumétrico.

\begin{tabular}{|c|c|c|c|}
\hline Coleta da amostra & Profundidade (m) & Amostras & $\begin{array}{c}\text { Condutividade } \\
\text { Hidráulica Média } \\
(\mathrm{cm} / \mathrm{s})\end{array}$ \\
\hline \multirow{7}{*}{$01 / 03 / 2013$} & 1,17 & 1.1 & $2,8 \mathrm{E}-02$ \\
\hline & 1,17 & 1.2 & $3,1 \mathrm{E}-02$ \\
\hline & 1,17 & 1.3 & $2,8 \mathrm{E}-02$ \\
\hline & 1,17 & 1.4 & $2,9 \mathrm{E}-02$ \\
\hline & 1,17 & 1.5 & $7,5 \mathrm{E}-02$ \\
\hline & 1,17 & 1.6 & $3,2 \mathrm{E}-02$ \\
\hline & 1,17 & 1.7 & $9,1 \mathrm{E}-02$ \\
\hline \multirow{4}{*}{$17 / 04 / 2013$} & 1,2 & 2.2 & $1,34 \mathrm{E}-03$ \\
\hline & 1,3 & 2.3 & $5,29 \mathrm{E}-04$ \\
\hline & 1,35 & 2.4 & $2,09 \mathrm{E}-03$ \\
\hline & 1,4 & 2.5 & $2,49 \mathrm{E}-03$ \\
\hline
\end{tabular}

\subsection{Análises Químicas}

\subsubsection{Cargas elétricas do solo, carbono total e inorgânico}

A CTC dos solos analisadas é relativamente baixa, inferior a $100 \mathrm{mmolc} / \mathrm{kg}$ (Tabela 17) (Embrapa, 2004), sendo que o LV apresentou o maior valor se comparado com os demais, provavelmente devido a textura deste solo bem como devido a maior concentração de carbono orgânico (Tabela 17). Segundo Meurer (2010) a CTC dos solos tropicais bem desenvolvidos tende a ser baixa devido ao predomínio de argilominerais 1:1 e óxidos de ferro e alumínio. Esta correlação entre baixos valores de CTC e solos tropicais deve-se ao fato destes solos apresentarem minerais com estrutura menos complexas (argilominerais 1:1) ao invés de minerais com arranjo cristalino mais complexo (2:1) os quais favorecem um maior déficit de carga permanente devido a substituições isomórficas no mineral.

Tabela 17 - Resultados das concentrações de carbono orgânico, cátions, $\mathrm{CTC}, \mathrm{V}, \mathrm{m}, \mathrm{pH}\left(\mathrm{H}_{2} \mathrm{O}\right), \mathrm{pH}(\mathrm{KCl})$.

\begin{tabular}{|c|c|c|c|c|c|c|c|c|c|c|c|c|}
\hline Amostra & $\mathrm{CO}$ & $\mathrm{K}^{+}$ & $\mathrm{Ca}^{2+}$ & $\mathrm{Mg}^{2+}$ & $\mathrm{Al}^{3+}$ & $\mathrm{H}^{+}$ & CTC & $\mathrm{V}$ & $\mathrm{m}$ & $\begin{array}{c}\mathrm{pH} \\
\left(\mathrm{H}_{2} \mathrm{O}\right)\end{array}$ & $\begin{array}{c}\mathrm{pH} \\
(\mathrm{KCl})\end{array}$ & $\Delta \mathrm{pH}$ \\
\hline & g/kg & \multicolumn{6}{|c|}{$\mathrm{mmolc} / \mathrm{kg}$} & $\%$ & $\%$ & - & - & - \\
\hline LVA & $\begin{array}{c}2,327 \\
\pm 0,3146\end{array}$ & $<0,2$ & 12 & 2 & 2 & 16 & 32,7 & 44 & 12 & 5,5 & 4,50 & $-1,00$ \\
\hline LV & $\begin{array}{c}15,756 \\
\pm 4,4125\end{array}$ & 0,2 & 6 & 1 & 21 & 63 & 91,3 & 8 & 75 & 4,9 & 4,20 & $-0,70$ \\
\hline NQ & $\begin{array}{c}0,696 \\
\pm 0,1970\end{array}$ & $<0,2$ & $<1$ & 1 & 2 & 9 & 11,7 & 10 & 68 & 5,1 & 4,30 & $-0,80$ \\
\hline
\end{tabular}

$\Delta \mathrm{pH}=\mathrm{pH}(\mathrm{KCl})-\mathrm{pH}\left(\mathrm{H}_{2} \mathrm{O}\right)$.

Comparando os valores de CTC obtidos com aqueles apresentados por Mello et al. (1993), nota-se que a amostra de solo do LVA teve CTC equivalente a dos óxidos de 
ferro e alumínio. Já os resultados relativos ao LV se assemelham a CTC do mineral caulinita. Contudo, conforme comentado anteriormente, a CTC do LV pode ter sido maior do que a observado no LVA devido à maior concentração de carbono orgânico.

A saturação por bases (V\%) representa a soma de base trocáveis (SB) do solo com exceção do $\mathrm{H}^{+}$e $\mathrm{Al}^{3+}$ sendo expressa em porcentagem de capacidade de troca de cátions. Este parâmetro é um dos utilizados para avaliação da fertilidade do solo e para classificação do solo, sendo que solos ditos como eutróficos correspondem a solos férteis com $\mathrm{V} \geq 50 \%$; e solos ditos distróficos com $\mathrm{V}<50 \%$, sendo solos pouco férteis. Valores baixos de "V" indicam que as cargas negativas do solo estão sendo neutralizadas por $\mathrm{H}^{+}$

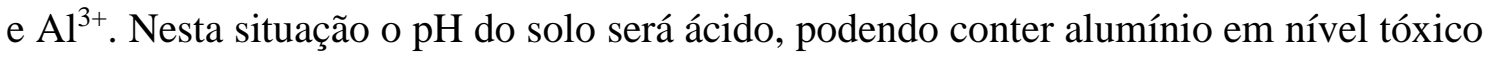
às plantas.

Alguns solos distróficos podem ser muito pobres em $\mathrm{Ca}^{2+}, \mathrm{Mg}^{2+} \mathrm{e} \mathrm{K}^{+}$e apresentar teor de alumínio trocável muito elevado, chegando a apresentar saturação em alumínio ( $\mathrm{m} \%$ ) superior a $50 \%$ e, nesse caso são classificados como solos álicos (muito pobres) quando a concentração de $\mathrm{Al}$ trocável foi maior ou igual a $3 \mathrm{mmolc} / \mathrm{dm}^{3} \mathrm{e}$ " $\mathrm{m}$ " superior a 50\%. (EMBRAPA, 2010).

Assim, verifica-se que o LV pode ser classificado como solo álico enquanto que o LVA e o NQ como solos distróficos. Tanto a amostra LV quanto a NQ apresentaram concentração de alumínio altamente prejudicial às plantas (Osak, 1991).

Com base nos resultados do $\mathrm{pH}$ do solo, verifica-se que todos os solos analisados possuem $\mathrm{pH}$ ácido. Os valores de $\Delta \mathrm{pH}$ das amostras LVA, LV e NQ (Tabela 18) indicam predomínio de cargas negativas na superfície do mineral. A diferença $(\Delta \mathrm{pH})$ entre o $\mathrm{pH}$ aferido quando o solo encontrava-se em solução de cloreto de potássio e o pH aferido quando o solo encontra-se em água, indica a predominância de cargas negativas ou positivas no solo. Quando as cargas de superfície do solo são negativas, íons $\mathrm{H}^{+}$tendem a ser adsorvidos à superfície do mineral de modo que, quando colocado em contato com a água não ocorre substituição entre os cátions, mas quando é acrescentado cloreto de potássio ocorre a transferência dos íons $\mathrm{H}^{+}$pelo cátion potássio $\left(\mathrm{K}^{+}\right)$, favorecendo assim a acidificação da solução e a redução do $\mathrm{pH}$, consequentemente resultando em $\Delta \mathrm{pH}$ negativo.

Por outro lado, quando o solo possui predomínio de óxidos e carga de superfície positivas, são capazes adsorver aníons como hidroxilas $\left(\mathrm{OH}^{-}\right)$o valor do $\mathrm{pH}$ na solução de $\mathrm{KCl}$ será maior do que o $\mathrm{pH}$ do solo em água. Isso ocorre devido à transferência da 
hidroxila ligada ao óxido pelo cloreto. Logo, nesta situação o valor da diferença entre o pH em água e o pH em $\mathrm{KCl}$ será positivo.

Conforme esperado, considerando o material de origem dos solos analisados, não foi detectado carbono inorgânico em nenhuma das amostras. O teor de carbono orgânico observado nas amostras do Latossolo foi maior do que o observado nas demais amostras, provavelmente devido à maior presença de argila e eventualmente a maior presença de óxidos que atuam como agentes cimentantes (ZIN et. al., 2012). A amostra do Neossolo também apresentou concentração baixa de carbono orgânico devido a sua textura, arenosa, e a ausência de estruturação.

O ponto de carga zero dos solos são apresentados na Tabela 17, solos de regiões tropicais normalmente apresentam teores elevados de óxido de ferro e alumínio. Estes óxidos apresentam valores elevados de PCZ (MEURER, 2010), elevando assim o PCZ do solo. Com base nos resultados obtidos e nos valores de PCZ de alguns minerais apresentados por Sparks (1995), verifica-se proximidade no valor de PCZ do LV (4,0) com o mineral caulinita $(4,6)$. Já o PCZ do LVA $(2,7)$ e do NQ $(2,5)$ se aproximam do valor de PCZ do quartzo (2,5-3,7). Contudo, ressalta-se que o valor obtido nas amostras é resultante da média do PCZ da mistura das partículas constituintes do solo (MEURER, 2010).

Considerando que a faixa do valor de $\mathrm{pH}$ onde ocorre o PCZ de solos com carga variável é igual a 3,5 a 5,0 (MEURER, 2010) conclui-se que dentre as amostras analisadas apenas a referente ao LV pode ser classificado como amostra de solo com carga variável ou seja, possui carga que depende do $\mathrm{pH}$ da solução do solo. As demais amostras estão relacionadas a cargas permanentes devido substituição isomórfica.

Tabela 18 - Valores de $\mathrm{pH}$ de cada um dos solos onde ocorre o ponto de carga zero.

\begin{tabular}{cc}
\hline Tabela $18-$ Valores de pH de cada um dos solos onde ocorre o ponto de carga zero. \\
\hline Solo & PCZ \\
\hline LVA & 2,70 \\
LV & 4,00 \\
NQ & 2,50 \\
\hline
\end{tabular}

No Anexo 2 são apresentados os gráficos com a intersecção das curvas potenciométricas obtidas para definição dos pontos de carga zero.

Considerando os valores do $\mathrm{pH}$ do solos LV, LVA e NQ, e os respectivos valores do PCZ, verifica-se predomínio de cargas negativas na superfície dos solos. Sendo assim, 
verifica-se que estes solos não tendem a sorver aníons, mas sim cátions. Logo os solos avaliados não tendem a adsorver e retardar os aníons de persulfato.

\subsubsection{Extração Sequencial do Ferro}

Com intuito de avaliar a participação do ferro presente na matriz sólida, na interação do persulfato com solo, optou-se por realizar a extração sequencial do ferro nas amostras. A extração sequencial permite avaliar eventuais deslocamento de ferro ligado as frações sólida após o processo de oxidação. Para tanto, avaliou-se a concentração de ferro trocável, ou seja, ferro ligado à superfície do mineral por forças eletrostática, a concentração de ferro ligado a matéria orgânica, a concentração de ferro ligado a óxidos amorfos e a concentração de ferro ligado a óxidos com estrutura cristalina (Tabela 19).

De acordo com os resultados é possível verificar que na fração trocável foram observadas as menores concentrações de ferro, sendo a menor na amostra LV seguida pela NQ e LVA. A concentração de ferro ligado a matéria orgânica foi superior a fração anterior, entretanto em relação a concentração total essa concentração ainda foi pouco expressiva. As maiores concentrações foram observadas na fração de ferro amorfo, seguido da fração de ferro cristalino, sendo as maiores concentrações observadas nas amostras do LV. A elevada concentração de ferro nas amostras LV poderá favorecer a formação de radicais livres e assim elevar o potencial de oxidação do persulfato.

Tabela 19 - Concentração de ferro trocável, ligado a matéria orgânica, aos óxidos e concentração total.

\begin{tabular}{|c|c|c|c|c|c|c|}
\hline \multicolumn{7}{|c|}{ Concentração de Ferro (mg/Kg) } \\
\hline \multirow[b]{2}{*}{ Frações } & \multicolumn{2}{|c|}{ LVA } & \multicolumn{2}{|c|}{$\mathrm{LV}$} & \multicolumn{2}{|c|}{ NQ } \\
\hline & $\begin{array}{c}\text { Média } \\
\pm \text { desvio }\end{array}$ & $\%$ & $\begin{array}{c}\text { Média } \\
\pm \text { desvio }\end{array}$ & $\%$ & $\begin{array}{c}\text { Média } \\
\pm \text { desvio }\end{array}$ & $\%$ \\
\hline Trocável & $\begin{array}{l}11 \\
\pm 2\end{array}$ & 0,11 & $\begin{array}{c}5 \\
\pm 0,21\end{array}$ & 0,01 & $\begin{array}{c}9 \\
\pm 1\end{array}$ & 0,13 \\
\hline Matéria Orgânica & $\begin{array}{l}30 \\
\pm 4\end{array}$ & 0,31 & $\begin{array}{c}42 \\
\pm 1,94\end{array}$ & 0,05 & $\begin{array}{l}27 \\
\pm 1\end{array}$ & 0,40 \\
\hline Óxidos Amorfos & $\begin{array}{l}5.830 \\
\pm 410\end{array}$ & 60,72 & $\begin{array}{r}76.158 \\
\pm 6.615\end{array}$ & 81,74 & $\begin{array}{l}4.550 \\
\pm 330\end{array}$ & 67,15 \\
\hline Óxido Cristalino & $\begin{array}{l}3.730 \\
\pm 600\end{array}$ & 38,85 & $\begin{array}{r}16.970 \\
\pm 3.632\end{array}$ & 18,21 & $\begin{array}{l}2.190 \\
\pm 495\end{array}$ & 32,32 \\
\hline Total de Fe nas frações & 9.601 & 100,0 & 93.175 & 100,0 & 6.776 & 100,0 \\
\hline
\end{tabular}

\subsection{Mineralogia - Difração de Raio-X e Análise Termogravimétrica}

Os principais minerais observados a partir dos difratogramas de raio-x na fração argila das amostras de solo, foram: caulinita $\left(\mathrm{Al}_{2} \mathrm{Si}_{2} \mathrm{O}_{5}(\mathrm{OH})_{4}\right)$, o óxido de ferro II cristalino Goethita $(\mathrm{FeO}(\mathrm{OH}))$, o hidróxido de alumínio Gibbsita $\left(\mathrm{Al}(\mathrm{OH})_{3}\right)$ e o óxido de ferro III cristalino, Hematita $\left(\mathrm{Fe}_{2} \mathrm{O}_{3}\right)$ (Figura 16). Outros picos com menor intensidade 
relativos a outros minerais menos expressivos também foram observados, mas estes não foram classificados.

A estrutura da caulinita é formada por estrutura dioctaedral. A sua cela unitária é formada por $\mathrm{Al}_{4} \mathrm{Si}_{4} \mathrm{O}_{10}(\mathrm{OH})_{8}$, distribuída por folhas octaedrais $(\mathrm{Al}-\mathrm{O} / \mathrm{AlOH})$ e tetraedrais (Si-O) (TEIXEIRA-NETO \& TEIXEIRA-NETO, 2009). As folhas adjacentes são acopladas por ligações de hidrogênio envolvendo grupos silanol $\equiv \mathrm{SiOH}$ e aluminol $\equiv$ Al-OH (ŠOLC et al., 2011).

Comparando os picos de cada um dos minerais para as amostras de argila de cada um dos solos, verifica-se que a fração argilosa da amostra LV apresentou menor intensidade para o mineral caulinita se comparado com a resposta da amostra do LVA e NQ, por outro lado, as amostras LV e NQ diferentemente da LVA apresentaram pico maiores para o mineral gibbisita. Além dos minerais citados verifica-se que a argila do LV apresentou também picos maiores para a hematita se comparada com as demais amostras, indicando assim maior participação dos óxidos de ferro e alumínio na composição mineralógica do LV. Este resultado vai de encontro com os resultados da extração sequencial do ferro já que a concentração de ferro foi maior para as amostras do Latossolo Vermelho.

Para diversos autores a presença de óxidos de ferro e alumínio na fração argilosa dos solos atuam como agentes ligantes de partículas de argila (JONES \& UEHARA, 1973; REICHERT \& NORTON, 1994; ITAMI \& KYUMA 1995; TISDALL \& OADES, 1982; FERREIRA et al., 1999).

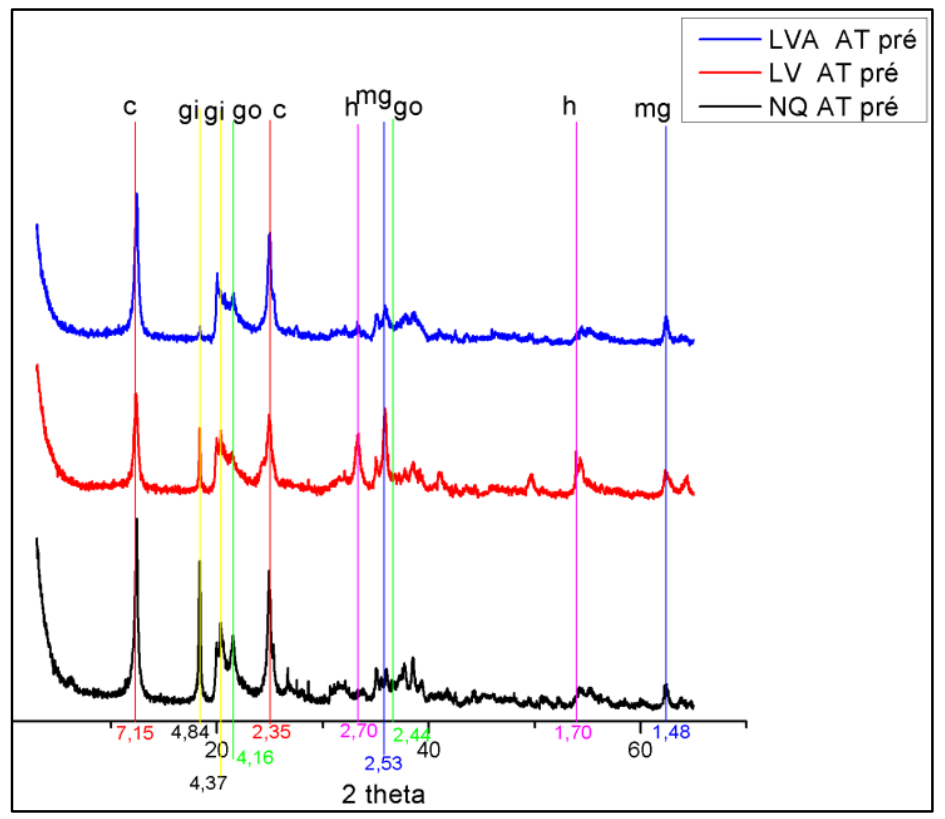

c: Caulinita; gi: Gibbsita; go: Goethita; h: Hematita; mg: Magnetita.

Figura 16 - Difratogramas da argila total das amostras do LVA, argila total do LV e argila total do NQ. 
As curvas referentes às análises térmicas diferenciais (DTA) demonstram 4 picos endotérmicos para todas as amostras de solo analisadas, sendo eles referente a perda de água adsorvida ao solo $\left(60-100^{\circ} \mathrm{C}\right)$, a gibbisita $\left(220-350^{\circ} \mathrm{C}\right)$ (LIMA, 2010), a caulinita $\left(350-550^{\circ} \mathrm{C}\right)$ e ao processo de desidroxilação do grupo $\mathrm{OH}$ ligado as folhas octaedrais do Alumínio da caulinita $\left(700-800^{\circ} \mathrm{C}\right)(\mathrm{CHENG}$, et al. 2010).

A célula unitária da caulinita $\mathrm{Al}_{4} \mathrm{Si}_{4} \mathrm{O}_{10}(\mathrm{OH})_{8}$ é composta por $46,54 \%$ de $\mathrm{SiO}_{2}$; $39,50 \%$ de $\mathrm{Al}_{2} \mathrm{O}_{3}$; e 13,96\%de $\mathrm{H}_{2} \mathrm{O}$, distribuída por folhas octaedrais ( $\left.\mathrm{Al}-\mathrm{O} / \mathrm{AlOH}\right)$ e tetraedrais (Si-O) (TEIXEIRA-NETO \& TEIXEIRA-NETO, 2009). Comparando a intensidade do pico endotérmico da DTA referente ao processo de desidroxilação de caulinita cada uma das amostras de argila (Figura 17 a 19), verifica-se que a amostra de solo LVA apresentou a maior intensidade em relação as demais, indicando assim como os difratogramas de raio-x maior representatividade deste mineral na amostra LVA. Em média a perda de massa nesse intervalo foi aproximadamente de 17,3; 15,6 e 11,9\%, para LVA, LV e NQ respectivamente, sendo que para a caulinita pura sem impurezas esse valor seria equivalente a 13,96\% (SILVA \& SANTANA, 2013).

Assim como os difratogramas das amostras apontaram maior quantidade de caulinita nas amostras de LVA em relação ao LV, a análise termogravimétrica demonstrou maior concentração de caulinita no LVA (Tabela 20). Sendo assim, levando em consideração ambos os resultados, acredita-se que a amostra do solo LV, apresenta elevada concentração de óxidos além de caulinita.

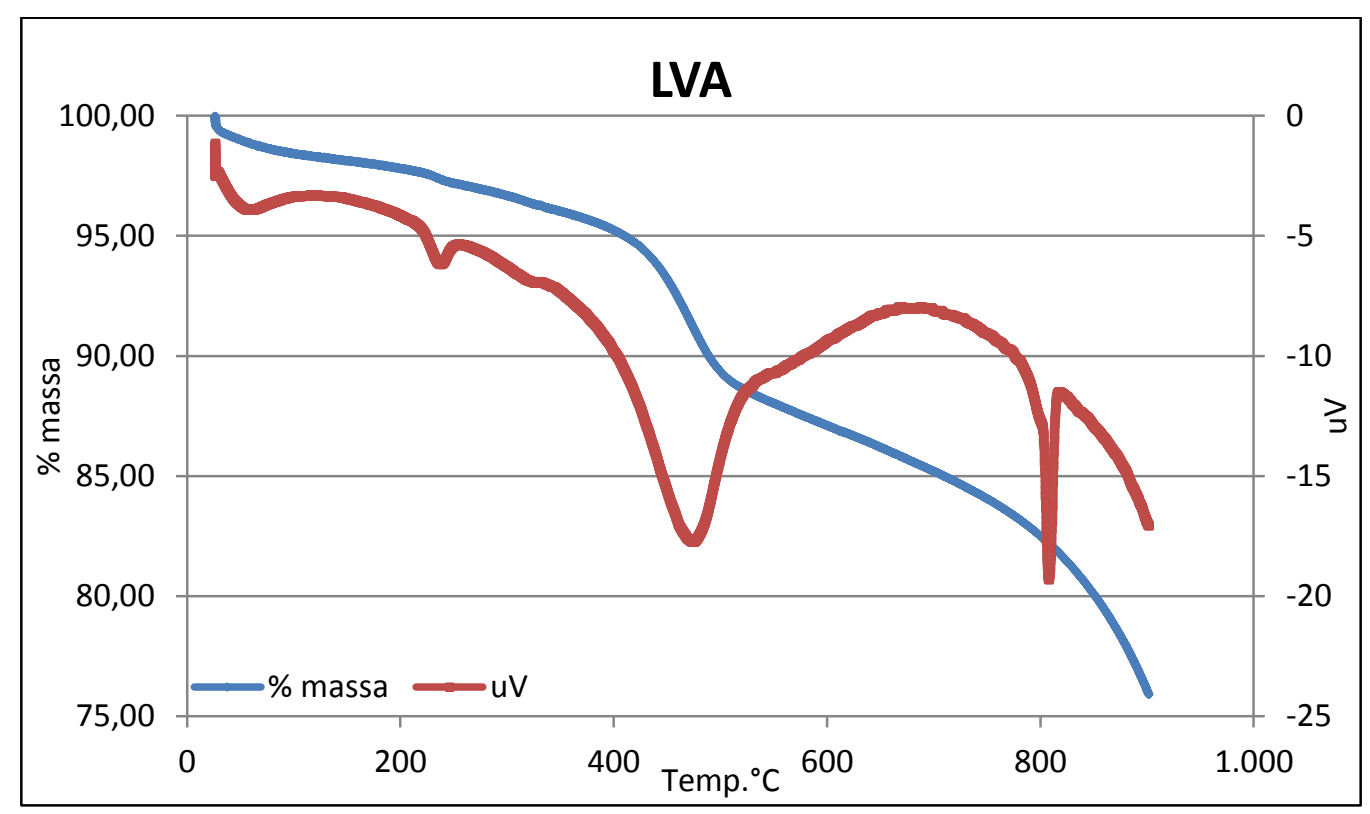

Figura 17 - DTA $(\mu \mathrm{V})$ e TG (\% massa) da amostra de solo LVA. 


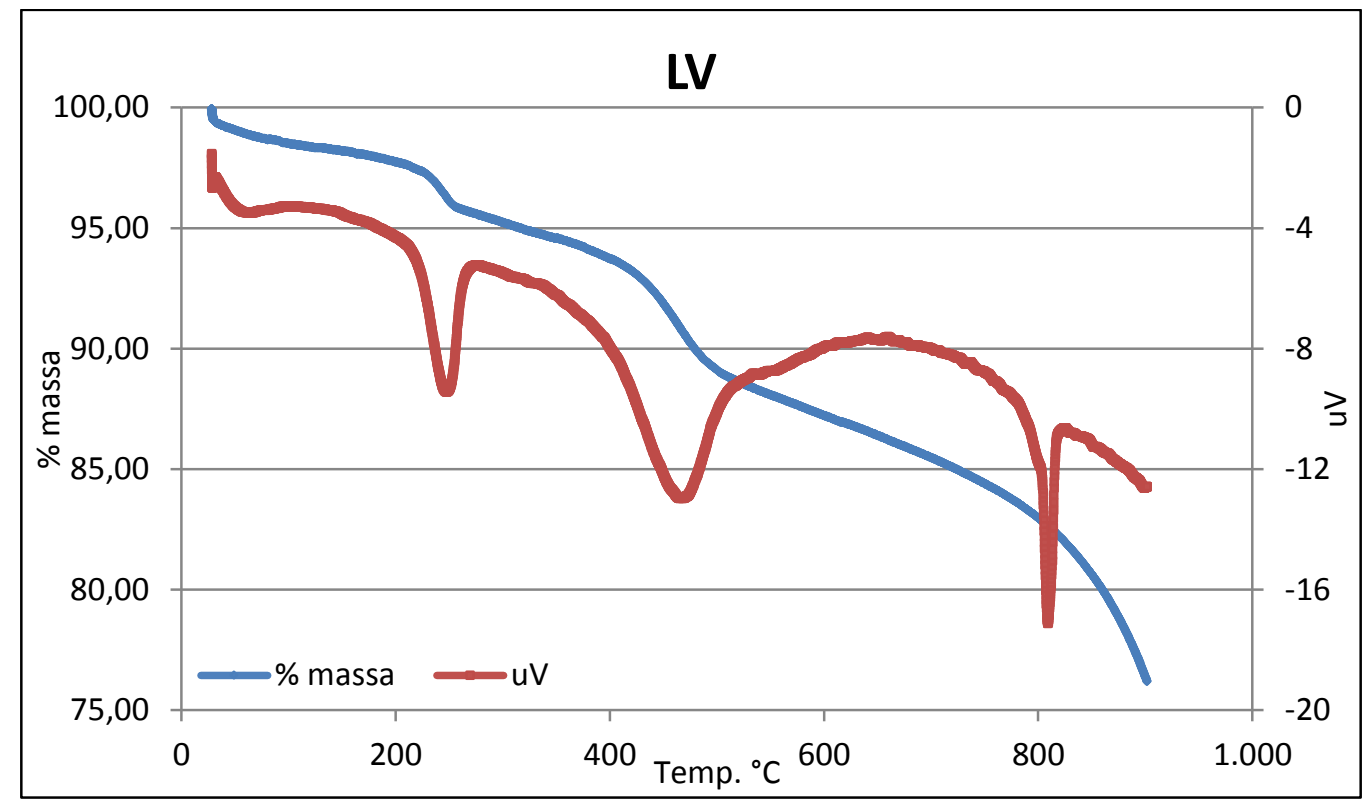

Figura 18 - DTA $(\mu \mathrm{V})$ e TG (\% massa) da amostra de solo LV.

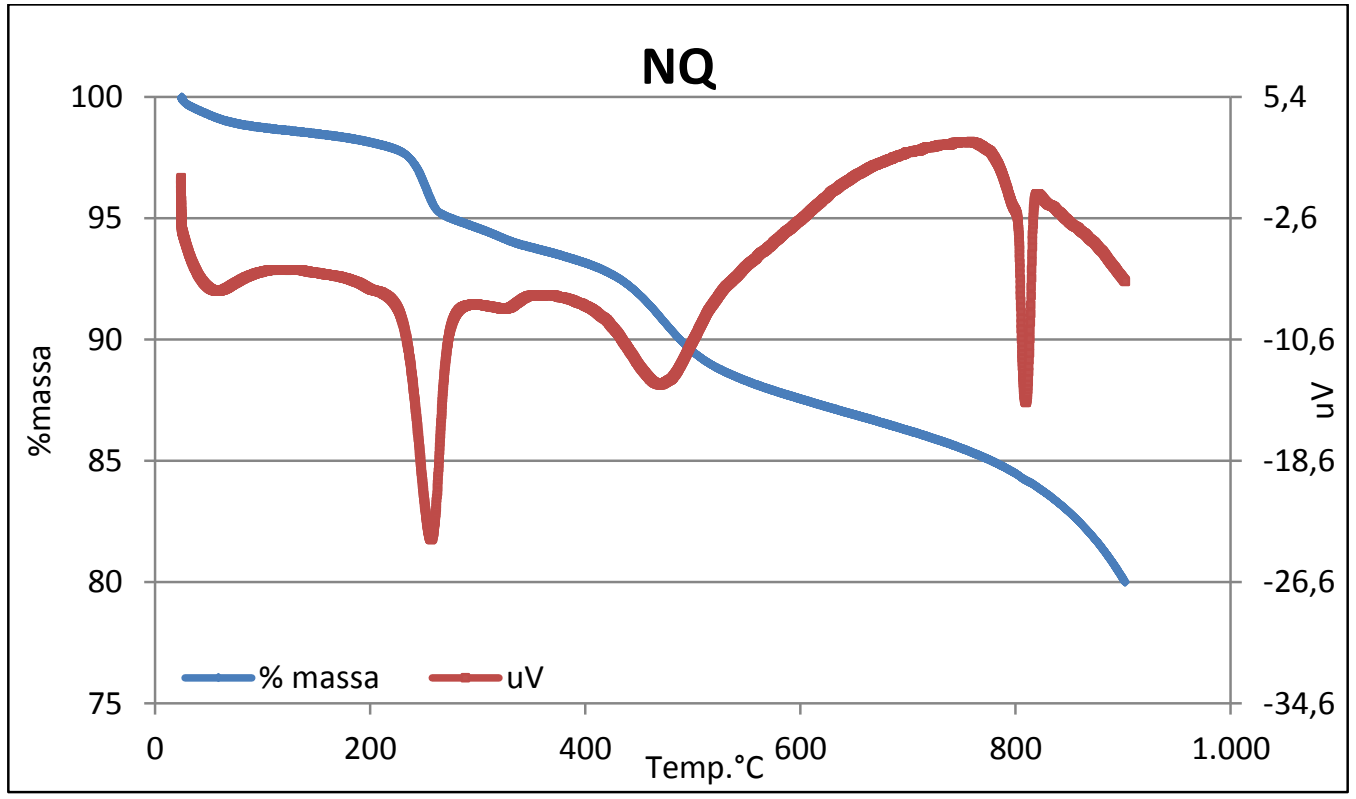

Figura 19 - DTA $(\mu \mathrm{V})$ e TG (\% massa) da amostra de solo NQ.

Assim como os difratogramas das amostras apontaram respectivamente maior intensidade no pico referente a gibbsita para as amostras NQ, LV e LVA, os resultados da análise térmica confirmam este resultado. Conforme apresentado na Tabela 20, a amostra de solo LV apresentou menor concentração de caulinita em relação ao LVA. Essa observação já era esperada pelo fato do estágio de desenvolvimento do LV favorecer a presença de óxidos e hidróxidos na fração mineralógica. Desta forma, apesar de menor concentração de caulinita, este solo apresentou maior concentração de hidróxido de alumínio, gibbisita em relação ao LVA. 
Tabela 20 - Resultados da concentração de caulinita e gibbisita por meio da interpretação da curva TG.

\begin{tabular}{ccc}
\hline Solo & Caulinita $\mathrm{g} / \mathrm{kg}$ & Gibbsita $\mathrm{g} / \mathrm{kg}$ \\
\hline LVA & 570,2 & 51 \\
\hline LV & 464,0 & 92 \\
\hline NQ & 393,0 & 125 \\
\hline
\end{tabular}

\subsection{Ensaio de Batelada}

A seguir são descritos os resultados relativos ao ensaio de oxidação realizado com os três tipos de solos coletados por meio de teste de batelada. Estes resultados revelam a interação entre o oxidante e o solo por meio na análise da constante da taxa de reação do decaimento do persulfato.

\subsubsection{Método de Quantificação de Persulfato}

Os limites de detecção e quantificação do persulfato foram obtidos considerando grau de liberdade equivalente a 99\%. Com base nos valores obtidos e considerando a curva de calibração o Limite de Detecção e Quantificação foram respectivamente 108,3 e 216,6 mg/L. Para corrigir eventuais interferências na absorbância no comprimento de onda de interesse $(454 \mathrm{~nm})$ devido a coloração da solução do solo foi adotado o método sugerido por Sra et al., (2010). Contudo, salienta-se que após a adição da massa de persulfato nos reatores foi observada a floculação das partículas em suspensão (Figura 20), o que reduziu a interferência dos sólidos nas análises.

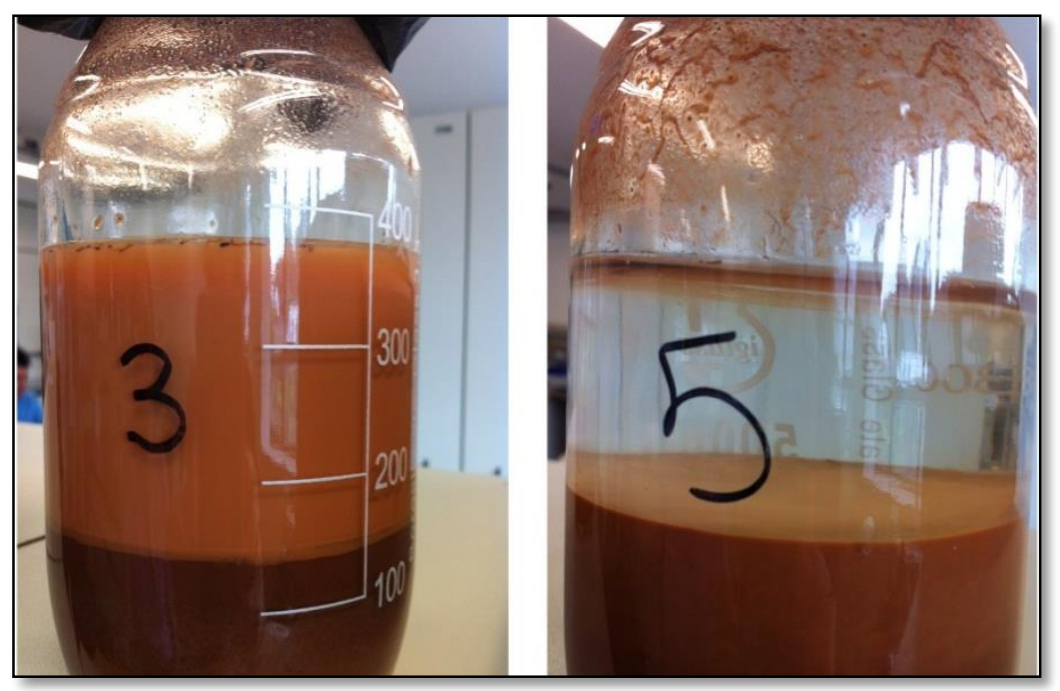

Figura 20 - Frasco 3: Reator com LV sem adição de persulfato; Frasco 5: Reator com LV e com adição de persulfato 


\subsubsection{Interação do Oxidante com os Solos}

Os gráficos a seguir representam o decaimento das concentrações de persulfato por um período de aproximadamente 120 dias. O gráfico da Figura 21 refere-se aos resultados do ensaio de batelada cuja concentração inicial foi $1 \mathrm{~g} / \mathrm{L}$ enquanto que o gráfico da Figura 22 é relativo aos resultados das amostras cuja concentração inicial de persulfato foi $14 \mathrm{~g} / \mathrm{L}$.

De acordo com os resultados nota-se que o decaimento seguiu o modelo de primeira ordem, sendo que o coeficiente de correlação foi superior a 0,9 em todos os testes, exceto para o Controle Tipo 2 com concentração inicial equivalente a $1 \mathrm{~g} / \mathrm{L}$ (Tabela 21). Conforme apresentado no gráfico da Figura 21, o solo onde o decaimento de persulfato foi mais rápido foi o LV. Em 30 dias a concentração de persulfato neste reator reduziu de 1 para 0 g/L (100\%) (Figura 21) e de 14 para 7 g/L (48\%) (Figura 22).

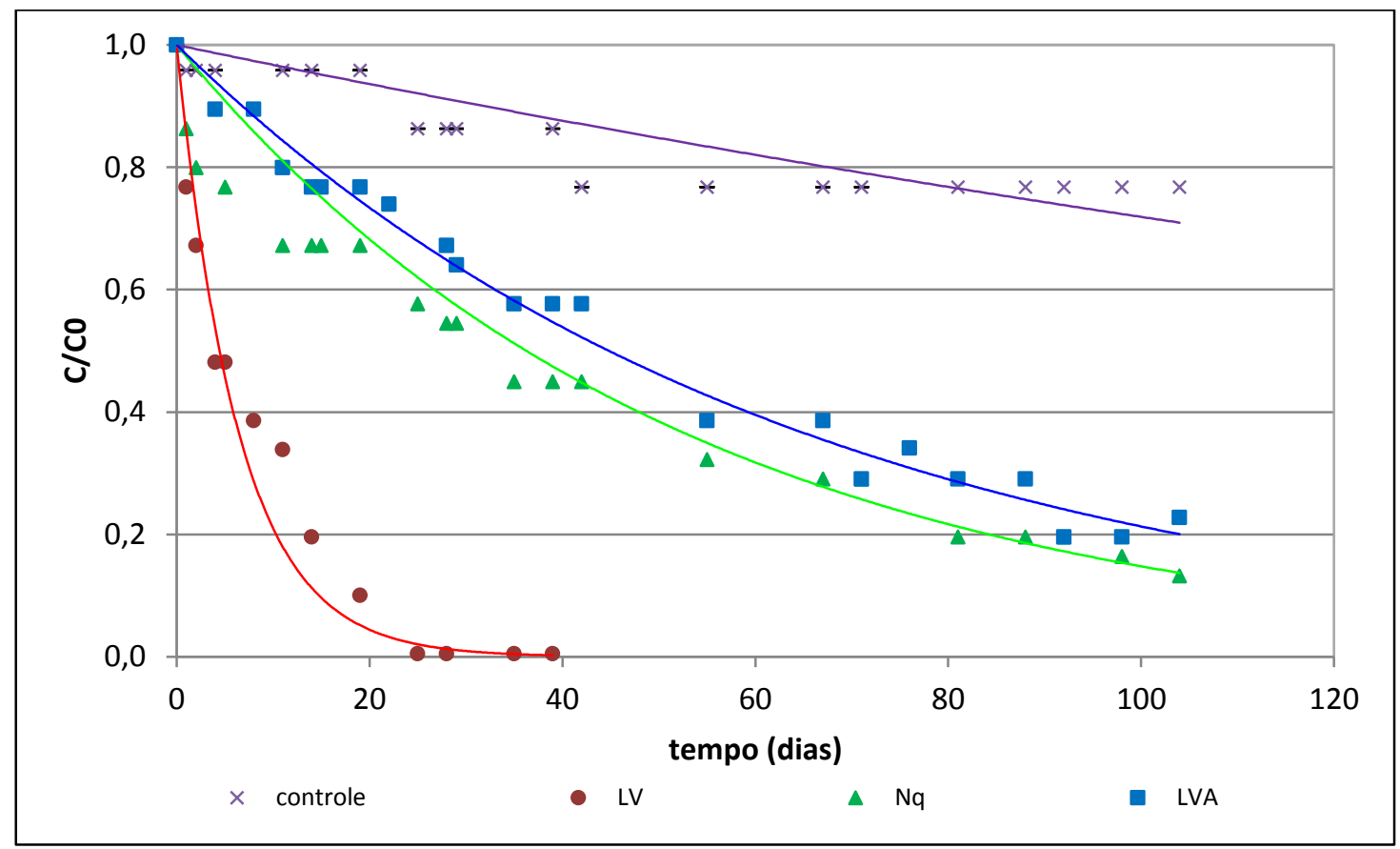

Figura 21 - Decaimento do persulfato nos reatores com concentração inicial de $1 \mathrm{~g} / \mathrm{L}$. Os pontos representam a média de triplicatas. As linhas contínuas representam resultados calculados por equação de reação de $1^{\mathrm{a}}$ ordem. 


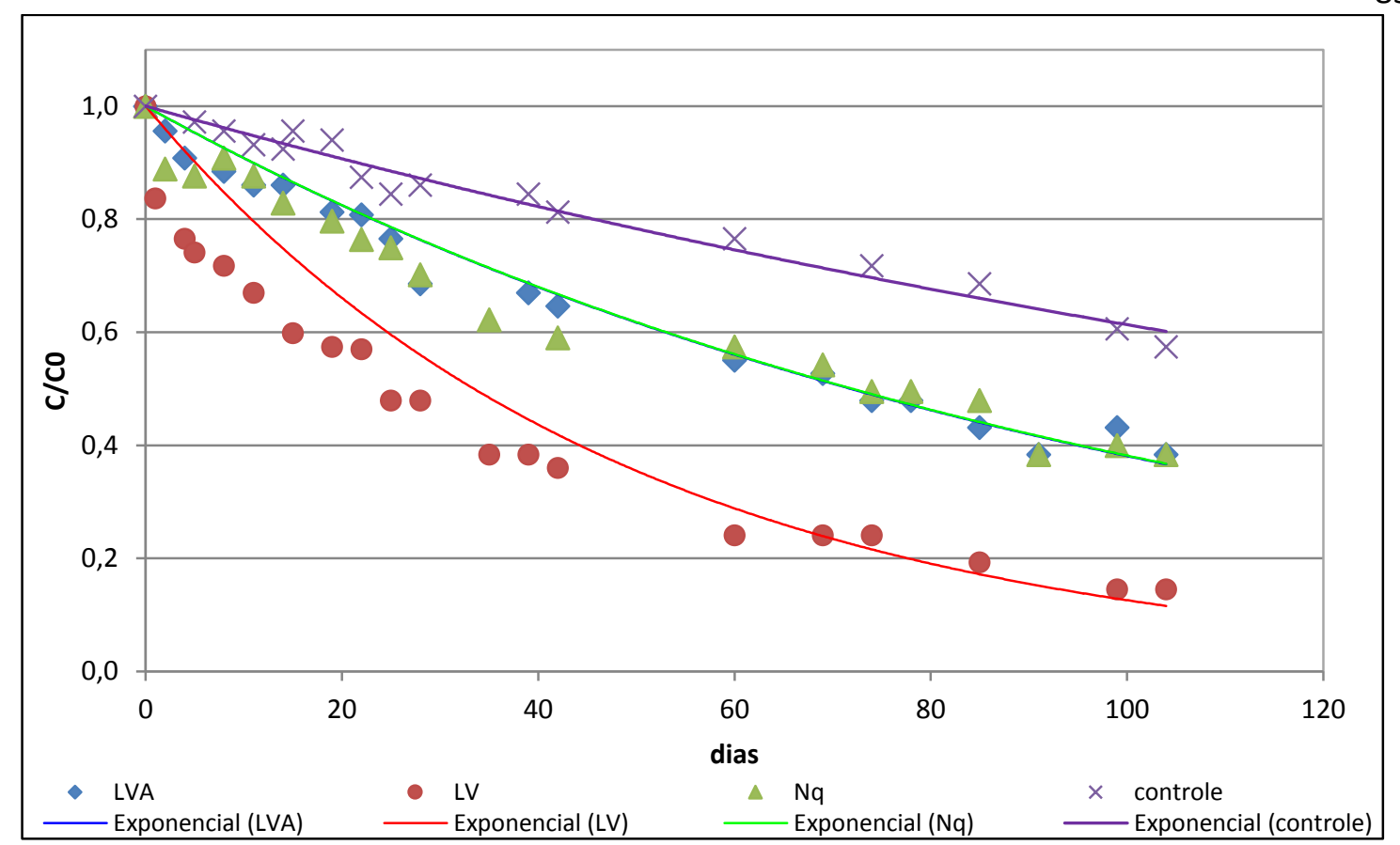

Figura 22 - Consumo de persulfato nos reatores com concentração inicial de 14g/L. Os pontos representam a média de triplicatas. As linhas contínuas representam resultados calculados por equação de reação de $1^{\text {a }}$ ordem.

As amostras do LVA apesar de possuírem área específica pelo menos 2 vezes maior do que a do NQ, possuir aproximadamente 3 vezes mais argila em massa e mineralogia distinta do NQ, causou decaimento do persulfato similar ao NQ, sendo que as curvas estiveram praticamente sobrepostas para os reatores com concentração inicial mais elevada de $14 \mathrm{~g} / \mathrm{L}$. Esta semelhança pode estar relacionada a participação da fração orgânica presente na amostra NQ.

As constantes da taxa de reação ( $\mathrm{K}_{\mathrm{obs}}$ ) (Tabela 21) foram significativamente superiores aquelas obtidas por Sra, Thomson e Barker (2010), os quais utilizaram sete amostras de solos não contaminado, de aquíferos diferentes de região de clima temperado, em geral compostos por areias inconsolidadas e silte. A constante da taxa de reação obtida para os solos brasileiros LV, LVA e NQ foram respectivamente de 3 a 33; 0,3 a 4 e 0,4 a 5 vezes maiores em relação as constantes obtidas por Sra, Thomson e Barker (2010). Estes autores também apresentaram valores de meia vida do persulfato não ativado em solos de clima temperado variando entre 2 a 600 dias, sendo que as concentrações de persulfato dos reatores foram 1 e $20 \mathrm{~g} / \mathrm{L}$. Considerando os resultados obtidos com os solos LV, LVA e NQ verifica-se que para a concentração inicial baixa $(1 \mathrm{~g} / \mathrm{L})$, a meia vida do persulfato foi respectivamente igual a 5,6; 46 e 38 dias enquanto que para os reatores com concentração superior $(14 \mathrm{~g} / \mathrm{L})$ a meia vida foi de 38,76 e 87 dias, respectivamente para o LV, LVA e NQ. Logo, a meia vida obtida para o persulfato em contato com solos 
brasileiros sendo dois deles tropicais, (5 a 87 dias) foi inferior aos obtido pelos autores citados. A maior concentração de ferro no LV pode ter sido responsável pelo maior valor da constante da taxa de reação, mas ao mesmo tempo radicais livres podem ter sido formados aumentando o potencial padrão de redução.

Comparando os resultados dos reatores LV, LVA e NQ com concentração inicial de 1 e 14g/L verifica-se que os reatores com concentração inicial menor apresentaram maiores valores para a constante da taxa de reação (Tabela 21). Pelo fato do decaimento ajustar-se ao modelo de primeira ordem, a diferença nos valores da constante " $k$ " não era esperada.

Tabela 21 - Valores das constantes da taxa de reação do decaimento do persulfato nos reatores com concentração inicial de 1 e 14g/L. Desvios padrão (dp) calculados com grau de confiança de $95 \%$.

\begin{tabular}{|c|c|c|c|c|c|c|c|}
\hline & \multicolumn{3}{|c|}{$1 \mathrm{~g} / \mathrm{L}$} & \multicolumn{3}{|c|}{$14 \mathrm{~g} / \mathrm{L}$} & \multirow{2}{*}{$\frac{k(C 1)}{k(C 2)}$} \\
\hline & $\mathrm{K}\left(\mathrm{d}^{-1}\right)$ & dp 95\% & $\mathrm{R}^{2}$ & $\mathrm{~K}\left(\mathrm{~d}^{-1}\right)$ & dp 95\% & $\mathrm{R}^{2}$ & \\
\hline LVA & 0,0132 & $\pm 0,0017$ & 0,9655 & 0,0090 & $\pm 0,0006$ & 0,9840 & 1,5 \\
\hline LV & 0,1588 & $\pm 0,0315$ & 0,9177 & 0,0175 & $\pm 0,0012$ & 0,9797 & 9,1 \\
\hline NQ & 0,0070 & $\pm 0,0009$ & 0,9285 & 0,0086 & $\pm 0,0007$ & 0,9717 & 0,8 \\
\hline $\begin{array}{c}\text { Controle } \\
\text { Tipo } 2\end{array}$ & 0,0020 & $\pm 0,0026$ & 0,8272 & 0,0038 & $\pm 0,0041$ & 0,9763 & 0,5 \\
\hline
\end{tabular}

Sra et al. (2010) também obtiveram constantes da taxa de reação diferentes para reatores com concentrações diferentes (1 e 20g/L). Segundo os autores, a constante $k_{\text {obs }}$ é inversamente proporcional à força iônica das soluções. Contudo, apesar da força iônica dos reatores LV, LVA, NQ e Controle (Tipo 2) com concentração inicial de 14g/L serem 14 vezes maiores do que a força iônica dos reatores com concentração inicial de $1 \mathrm{~g} / \mathrm{L}$, a razão entre as constantes da taxa de reação dos reatores com maior e menor concentração apresentaram valores diferentes para amostras de solo diferentes, indicando que o valor das constantes para reatores com concentração inicial diferentes não depende apenas da força iônica. Para a solução Controle Tipo 2, a razão entre as constantes dos reatores com concentração inicial de 14 e $1 \mathrm{~g} / \mathrm{L}$ foi equivalente a 2,1 enquanto que a razão entre as forças iônicas dos reatores de 14 e $1 \mathrm{~g} / \mathrm{L}$ foi igual 14, ou seja, uma relação 7 vezes maior do que aquela obtida para as constantes. Se a variação da constante da taxa de degradação da solução de persulfato sem contato com o solo depender apenas da relação entre as forças iônicas seria possível escrever a equação a seguir:

$$
\frac{k_{2}}{k_{1}}=\frac{\mu 2}{7 \times \mu 1}
$$

Sendo,

$k_{2}$ : constante da taxa de reação para solução de persulfato de $14 \mathrm{~g} / \mathrm{L}$. 
$k_{1}$ : constante da taxa de reação para solução de persulfato de $1 \mathrm{~g} / \mathrm{L}$

$\mu 2$ : força iônica da solução de persulfato de $14 \mathrm{~g} / \mathrm{L}$.

$\mu 1$ : força iônica da solução de persulfato de $1 \mathrm{~g} / \mathrm{L}$.

A massa de persulfato degradada nos reatores com concentração inicial de $14 \mathrm{~g} / \mathrm{L}$ foi 3,57g (85\%); 2,60g (62\%); 2,60g (62\%) para o LV, LVA e NQ, respectivamente. Já nos reatores com concentração inicial baixa $(1 \mathrm{~g} / \mathrm{L})$ a massa de persulfato perdida foi $0,43 \mathrm{~g}$ (100\%); 0,36g (84\%) e 0,39g (91\%), para o LV, LVA e NQ, respectivamente.

Devido à diferença entre os valores das constantes da taxa de reação, o modelo pode ser representado por um modelo de pseudo-primeira ordem, sendo que a constante passa a depender de algumas propriedades do solo (SRA et al., 2010). O decaimento pode ser ajustado a um modelo de pseudo primeira ordem quando existe excesso de um dos reagentes ou na presença de catalisador. Nesta situação o decaimento pode ser escrito como:

$$
\frac{d C a}{d t}=k \cdot A \cdot B
$$

$\mathrm{dCa} / \mathrm{dt}$ : velocidade da reação;

k: constante da taxa da reação da substância "A";

A: concentração da substância A;

B: substância em excesso ou catalisador.

Nesta condição, onde um dos reagente se encontra em excesso ou trata-se de um catalisador, sua concentração pode ser considerada constante e passa a ser incorporado na constante " k' ", e a equação da taxa da reação passa a ser escrita conforme apresentado na eq. (31).

$$
\frac{d C a}{d t}=k^{\prime} \cdot A
$$

A constante da taxa de reação do LV mostrou-se 22 e 12 vezes maior do que a obtida para o NQ e LVA, respectivamente, para os reatores com menor concentração inicial de persulfato $(1 \mathrm{~g} / \mathrm{L})$. Já nos reatores com concentração mais elevada (14 g/L), o valor da constante referente ao LV foi 2 vezes maior do que a obtida para o LVA e NQ.

De acordo com Liu et al. 2014, a taxa de decomposição do persulfato segue o modelo de pseudo-primeira ordem, sendo que a constante da taxa de reação ( $\mathrm{k}_{\mathrm{obs}}$ ) é o produto entre a área superficial e a constante da taxa de reação normalizada pela área superficial ( $\mathrm{k}_{\text {norm}}$ ) conforme apresentado na Equação 7. A normalização da constante da taxa pela área superficial possibilita correlacionar o valor da constante da taxa de reação dos solos com suas áreas superficiais (Tabela 22). Entretanto, com base nos valores 
observa-se que a constante $\mathrm{k}_{\mathrm{obs}}$ não depende exclusivamente da área superficial já que os valores das constantes normalizadas ainda são diferentes para os três tipos de solo.

Para os reatores com concentração inicial igual a $14 \mathrm{~g} / \mathrm{L}$, a constante do LVA foi aproximadamente igual a 2 vezes maior do que a obtida para o LV e 2 vezes menor do que aquela obtida para o NQ. A constante normalizada para o NQ foi 4 vezes maior do que a do LV para reator com concentração inicial igual a $14 \mathrm{~g} / \mathrm{L}$.

Tabela 22 - Valores do constante da taxa de reação para os reatores com concentração inicial igual a 1 e 14g/L calculado a partir da normalização da área conforme sugerido por Liu et al. 2014.

\begin{tabular}{ccccc}
\hline \multirow{2}{*}{ Amostras } & \multicolumn{2}{c}{$\mathbf{1 g} / \mathbf{L}$} & \multicolumn{2}{c}{$\mathbf{1 4 g} / \mathbf{L}$} \\
\cline { 2 - 5 } & $\begin{array}{c}\text { Kobs } \\
\left(\mathrm{d}^{-1}\right)\end{array}$ & $\begin{array}{c}\text { Knorm } \\
\left(\mathrm{d}^{-1} \cdot \mathrm{m}^{-2}\right)\end{array}$ & $\begin{array}{c}\text { Kobs } \\
\left(\mathrm{d}^{-1}\right)\end{array}$ & $\begin{array}{c}\mathrm{Knorm} \\
\left(\mathrm{d}^{-1} \cdot \mathrm{m}^{-2}\right)\end{array}$ \\
\hline LVA & $1,32 \mathrm{E}-02$ & $4,48 \mathrm{E}-06$ & $0,90 \mathrm{E}-02$ & $3,07 \mathrm{E}-06$ \\
\hline LV & $15,88 \mathrm{E}-02$ & $1,56 \mathrm{E}-05$ & $1,75 \mathrm{E}-02$ & $1,71 \mathrm{E}-06$ \\
\hline NQ & $0,70 \mathrm{E}-02$ & $5,67 \mathrm{E}-06$ & $0,86 \mathrm{E}-02$ & $6,94 \mathrm{E}-06$ \\
\hline
\end{tabular}

O comportamento do decaimento da massa de persulfato no reator LV cuja concentração inicial foi igual a $1 \mathrm{~g} / \mathrm{L}$ apresentou dois comportamentos diferentes. $\mathrm{O}$ primeiro foi observado até o sétimo dia do ensaio e o segundo entre 7 e 30 dias. Nos primeiros 7 dias, o decaimento poderia ser expresso por um modelo de ordem zero, no qual a taxa é igual a uma constante, enquanto no segundo período o melhor ajuste para o decaimento seria de primeira ordem. Esse comportamento, indica que inicialmente um ou mais constituinte(s) do solo interagiu com o oxidante, sendo que após os primeiros 7 dias, este(s) constituinte(s) já havia(m) se esgotado. Para avaliar essa afirmação, elevou-se novamente a concentração dos reatores para a condição inicial $(1 \mathrm{~g} / \mathrm{L})$ e monitorou-se a concentração de persulfato no tempo, durante mais 47 dias (Figura 23). 


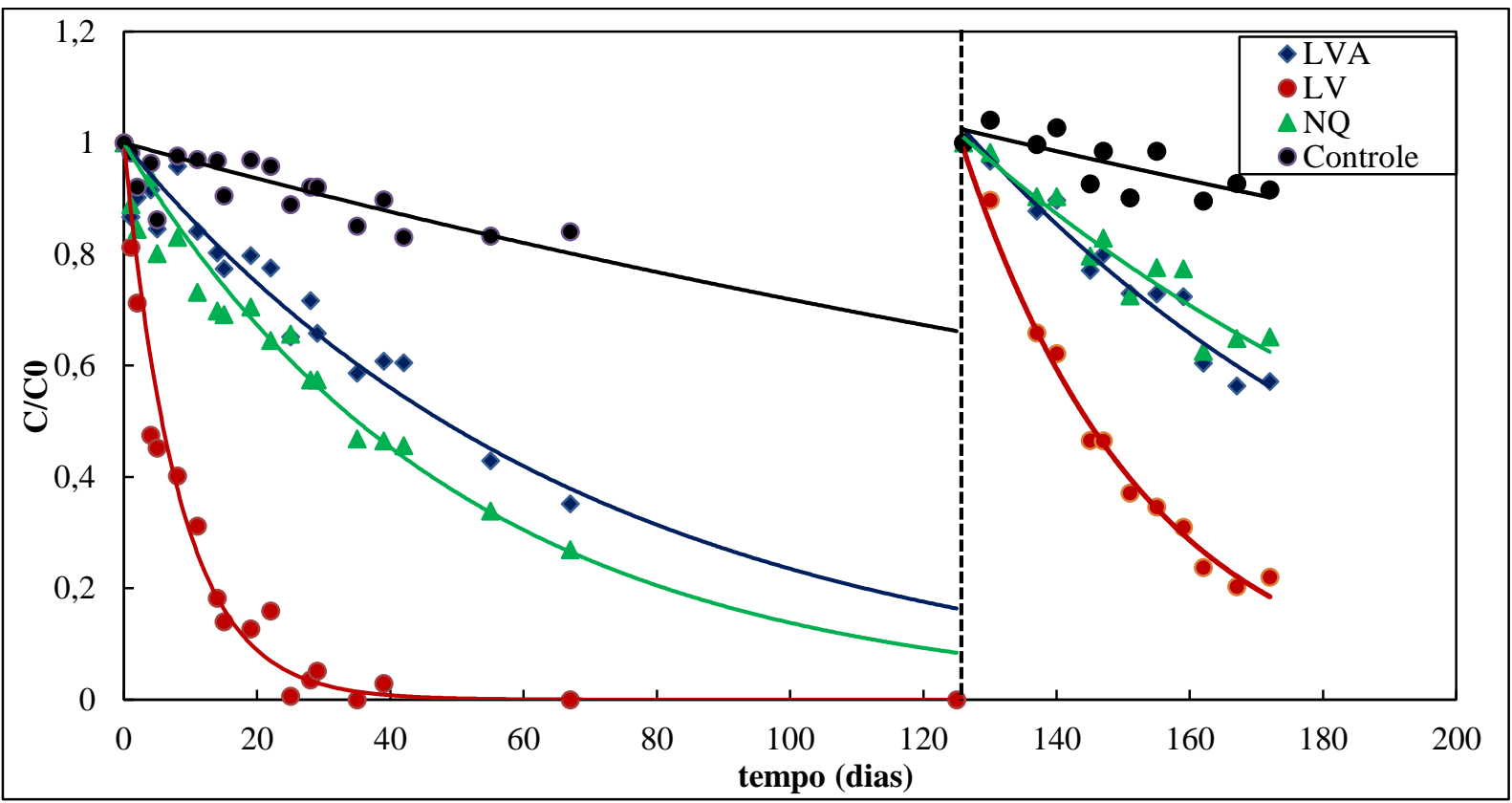

Figura 23 - Decaimento da concentração de persulfato após a primeira adição de oxidante e depois da segunda elevação da concentração de oxidante.

De acordo com os resultados, após a segunda adição de persulfato nos reatores o decaimento do persulfato se ajustou ao modelo de primeira ordem. No entanto, a constante da reação do persulfato em contato com o LV foi aproximadamente 4 vezes inferior ao valor da constante observada após a primeira adição (Tabela 23), confirmando assim, o consumo inicial mais rápido do persulfato por uma ou mais substância(s) presente(s) no LV em condições ácidas. As constantes para os outros solos não apresentaram variações significativas.

Tabela 23 - Valores das constantes da taxa de reação do decaimento do persulfato nos reatores com concentração inicial de $1 \mathrm{~g} / \mathrm{L}$ após a $1^{\mathrm{a}}$ adição e a $2^{\mathrm{a}}$ adição de persulfato, desvio padrão (dp), $\mathrm{R}^{2} \mathrm{e}$ razão entre as constantes $\mathrm{k}$ da $1^{\mathrm{a}}$ e $2^{\mathrm{a}}$ adição.

\begin{tabular}{|c|c|c|c|c|c|}
\hline & $1^{\mathrm{a}}$ adição & & $2^{\mathrm{a}}$ adição & & $\overline{k\left(1^{a} a d i c ̧ a ̃ o\right)}$ \\
\hline Amostra & $\mathrm{k}\left(\mathrm{d}^{-1}\right)$ & $\mathrm{k}\left(\mathrm{d}^{-1}\right)$ & dp $95 \%$ & $\mathrm{R}^{2}$ & $\overline{\left.\boldsymbol{k ( 2 ^ { a } a d i c ̧ a ̃ o}\right)}$ \\
\hline LVA & 0,0132 & 0,0123 & $\pm 0,0011$ & 0,9827 & 1,1 \\
\hline $\mathbf{L V}$ & 0,1588 & 0,0368 & $\pm 0,0018$ & 0,9945 & 4,3 \\
\hline NQ & 0,0070 & 0,0101 & $\pm 0,0013$ & 0,9689 & 0,7 \\
\hline Controle Tipo 2 & 0,0020 & 0,0016 & $\pm 0,0012$ & 0,4694 & 1,3 \\
\hline
\end{tabular}

\subsubsection{Potencial de Redução e pH da Solução dos Reatores}

A Tabela 24 possui os resultados do $\mathrm{pH}$ aferido nos reatores. Com base nos resultados pode-se perceber que em geral houve um decréscimo do $\mathrm{pH}$ ao longo do tempo, sendo que o LV teve maior capacidade de tamponamento da solução. Considerando o balanço estequiométrico das reações do persulfato em meios com acidez diferente 
(Tabela 4), acredita-se que tenha sido formado peróxido de hidrogênio $\left(\mathrm{H}_{2} \mathrm{O}_{2}\right)$ nos reatores com concentração inicial igual a 1 e $14 \mathrm{~g} / \mathrm{L}$ já que o pH da solução esteve entre 3 e 5,5 após a adição do persulfato nos reatores. De acordo com o mecanismo de reação apresentado na Tabela 4 é possível observar que no reator Controle Tipo 2 pode ter ocorrido a degradação do persulfato por catálise ácida já que o pH foi inferior a 3 .

A acidificação da solução ocorre devido à liberação de $\mathrm{H}^{+}$da degradação do persulfato por reações de hidrólise (Tabela 4), contudo a catálise ácida só ocorre em meio com pH inferior a 3, nesta condição é gerado ácido persulfúrico também conhecido como Ácido de Caro (KOLTHOFF e MILLER, 1951).

Considerando ainda, o valor do PCZ do LV e os valores de pH da solução de persulfato em contato com esse solo verifica-se que nos reatores com concentração inicial igual a $14 \mathrm{~g} / \mathrm{L}$ verifica-se que a carga líquida do solo pode ter sido positiva podendo assim ter ocorrido a adsorção de aníons de persulfato e sulfato já que o valor de pH após 1 e 15 dias da adição do oxidante foi inferior ao valor de PCZ do solo.

Tabela 24 - pH da solução dos reatores antes da adição de oxidante, um e quinze dias após a adição.

\begin{tabular}{|c|c|c|c|c|c|}
\hline & & \multicolumn{4}{|c|}{ pH } \\
\hline & & $\begin{array}{l}\text { Antes da } \\
\text { adição de } \\
\text { oxidante }\end{array}$ & $\begin{array}{l}\text { Após } 1 \text { dia } \\
\text { da adição }\end{array}$ & $\begin{array}{c}\text { Após } 15 \\
\text { dias da } \\
\text { adição }\end{array}$ & $\Delta \mathrm{pH}($ dia $15-$ dia 0$)$ \\
\hline \multirow{3}{*}{ LVA } & Controle 1 & 5,60 & 5,60 & 5,52 & $-0,08$ \\
\hline & $1 \mathrm{~g} / \mathrm{L}$ & 5,62 & 4,55 & 4,46 & $-1,16$ \\
\hline & $14 \mathrm{~g} / \mathrm{L}$ & 5,61 & 3,33 & 3,12 & $-2,49$ \\
\hline \multirow{3}{*}{$\mathbf{L V}$} & Controle 1 & 4,76 & 4,80 & 4,68 & $-0,08$ \\
\hline & $1 \mathrm{~g} / \mathrm{L}$ & 4,76 & 4,02 & 4,01 & $-0,74$ \\
\hline & $14 \mathrm{~g} / \mathrm{L}$ & 4,78 & 3,21 & 3,31 & $-1,46$ \\
\hline \multirow{3}{*}{ NQ } & Controle 1 & 5,10 & 4,68 & 4,64 & $-0,47$ \\
\hline & $1 \mathrm{~g} / \mathrm{L}$ & 5,11 & 3,92 & 3,77 & $-1,35$ \\
\hline & $14 \mathrm{~g} / \mathrm{L}$ & 4,96 & 3,09 & 2,99 & $-1,97$ \\
\hline \multirow{2}{*}{$\begin{array}{c}\text { Controle } \\
\text { Tipo } 2\end{array}$} & $1 \mathrm{~g} / \mathrm{L}$ & 6,48 & 4,06 & 3,49 & $-2,99$ \\
\hline & $14 \mathrm{~g} / \mathrm{L}$ & 5,94 & 3,29 & 2,60 & $-3,34$ \\
\hline
\end{tabular}

Considerando o balanço estequiométrico (eq. 32 e 33) foi calculada a concentração de íons $\mathrm{H}^{+}$gerados devido a decomposição do persulfato nos reatores Controle Tipo 2. Com base na degradação do persulfato, 0,0014 e 0,0032mol/L de íons $\mathrm{H}^{+}$teriam sido gerados após 15 dias nos Controles Tipo 2, com concentração de 1 e 14g/L, respectivamente. Com as concentrações dos íons $\mathrm{H}^{+}$verifica-se que o $\Delta \mathrm{pH}$ no Controle Tipo 2 com concentração inicial de 1 e $14 \mathrm{~g} / \mathrm{L}$ deveria ser igual a 2,85 e 2,19, sendo que o $\Delta \mathrm{pH}$ aferido nesse período foi igual a 2,9 e 3,3 . 


$$
\begin{aligned}
\mathbf{S}_{2} \mathbf{O}_{\mathbf{8}}^{2-}+\mathrm{H}_{2} \mathrm{O} & \rightarrow \mathbf{2} \mathrm{HSO}_{4}^{-}+\mathbf{1} / \mathbf{2} \mathrm{O}_{2} \\
\mathrm{HSO}_{4}^{-} & \rightarrow \mathrm{H}^{+}+\mathrm{SO}_{4}^{2-}
\end{aligned}
$$

Comparando ainda os valores de $\mathrm{pH}$ com os resultados de PCZ, verifica-se que ao longo do período de monitoramento, o pH da solução do solo LVA e NQ estiveram acima do valor do PCZ. Sendo assim, ao menos nos 15 primeiros dias, houve o predomínio de cargas elétricas negativas na superfície do solo. Observa-se ainda que após 15 dias de oxidação o pH da solução esteve próximo ao valor de $\mathrm{pH}$ do PCZ em todas as amostras. Esta proximidade do $\mathrm{pH}$ da solução com o pH do PCZ pode explicar porque foi observada a floculação das partículas do solo inicialmente suspensa na solução após a adição do persulfato de potássio.

Além do $\mathrm{pH}$, monitorou-se o potencial de redução das soluções dos reatores do ensaio de batelada (Tabela 25). De acordo com as Tabelas 24 e 25, após o acréscimo da solução de persulfato houve a elevação do potencial de oxidação da solução e redução do valor de $\mathrm{pH}$. Indicando assim que o meio encontrava-se cada vez mais oxidante e ácido com a elevação da concentração de persulfato.

Tabela 25 - Variação do potencial de redução (ORP) da solução dos reatores antes da adição de oxidante,

\begin{tabular}{|c|c|c|c|c|c|}
\hline & & \multicolumn{4}{|c|}{ ORP (mV) } \\
\hline & & Sem oxidante & $\begin{array}{l}\text { Após } 1 \text { dia } \\
\text { da adição }\end{array}$ & $\begin{array}{l}\text { Após } 15 \text { dias } \\
\text { da adição }\end{array}$ & $\Delta \mathrm{mV}$ \\
\hline \multirow{3}{*}{ LVA } & Controle 1 & 284 & 441 & 420 & 136 \\
\hline & $1 \mathrm{~g} / \mathrm{L}$ & 285 & 497 & 488 & 203 \\
\hline & $14 \mathrm{~g} / \mathrm{L}$ & 272 & 557 & 565 & 294 \\
\hline \multirow{3}{*}{$\mathbf{L V}$} & Controle 1 & 301 & 431 & 472 & 172 \\
\hline & $1 \mathrm{~g} / \mathrm{L}$ & 311 & 479 & 513 & 202 \\
\hline & $14 \mathrm{~g} / \mathrm{L}$ & 313 & 531 & 553 & 240 \\
\hline \multirow{3}{*}{ NQ } & Controle 1 & 260 & 470 & 456 & 195 \\
\hline & $1 \mathrm{~g} / \mathrm{L}$ & 273 & 507 & 514 & 241 \\
\hline & $14 \mathrm{~g} / \mathrm{L}$ & 281 & 606 & 605 & 325 \\
\hline \multirow{2}{*}{ Controle 2} & $1 \mathrm{~g} / \mathrm{L}$ & 183 & 452 & 448 & 265 \\
\hline & $14 \mathrm{~g} / \mathrm{L}$ & 209,67 & 568,33 & 608,33 & 399 \\
\hline
\end{tabular}
um e quinze dias após a adição.

Considerando o diagrama de $\mathrm{pH}$-Eh do ferro para espécies ligada a hidroxilas e oxigênio foi possível avaliar que a forma de ferro presente na solução durante o processo de oxidação não foi alterada, sendo que o ferro permaneceu na forma de ferro $3+$ durante os primeiros 15 dias da oxidação, mas houve ainda assim alteração no equilíbrio já que após os 15 primeiros dias de adição de persulfato a 1 e 14g/L houve deslocamento na condição de equilíbrio do meio de modo que a forma de ferro se deslocou em direção a formação de íons de ferro livre (Figura 24). 

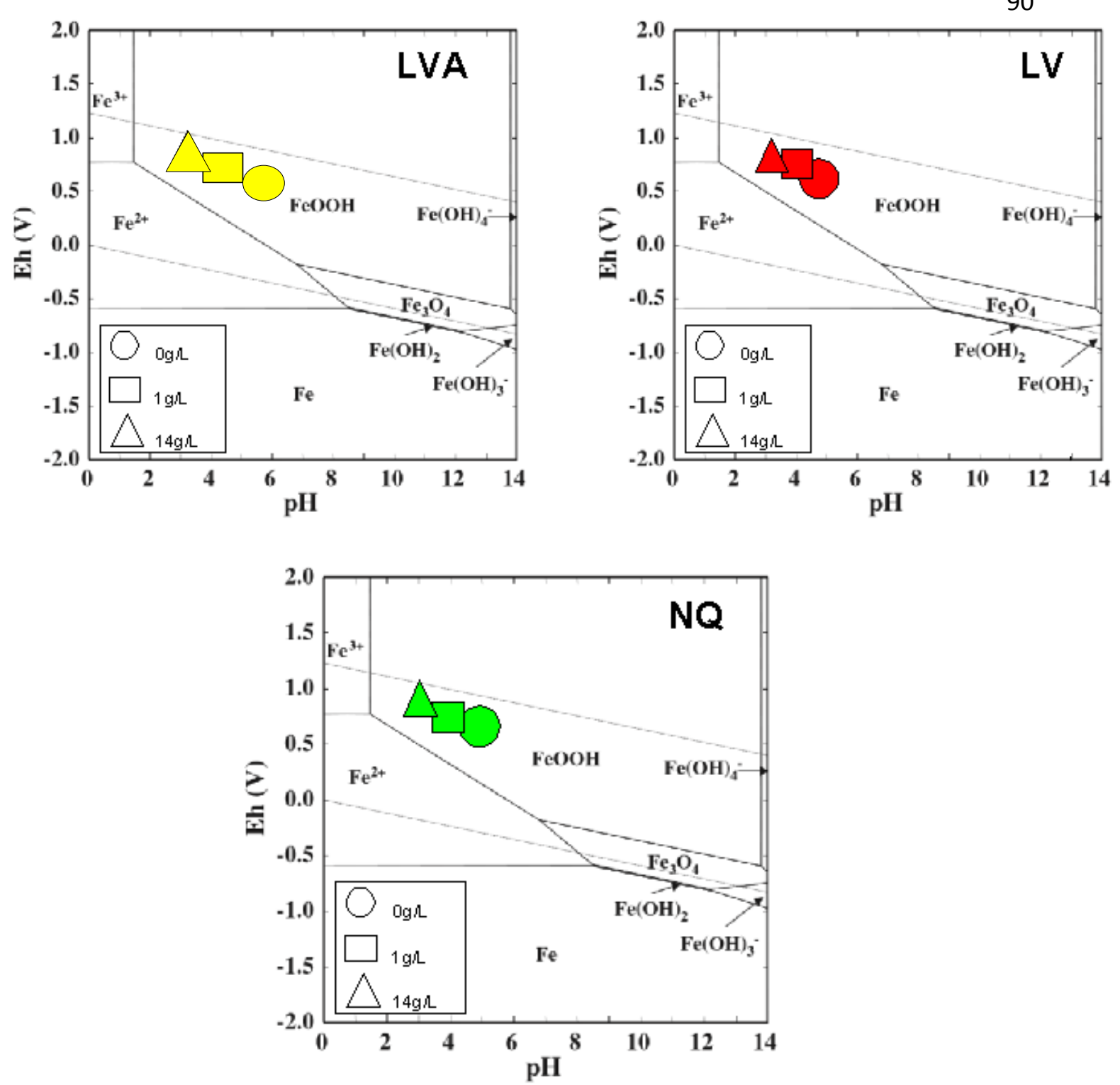

Figura 24 - Valores de Eh e pH durante os 15 primeiros dias da oxidação das amostras LVA, LV e NQ com concentração inicial igual a 0,1 e $14 \mathrm{~g} / \mathrm{L}$ plotadas no Diagrama de Eh-pH para sistema $\mathrm{Fe}-\mathrm{H}_{2} \mathrm{O}$ a 25 ${ }^{\circ} \mathrm{C}$. (Adaptado de KIM E ASARE, 2012).

\subsection{Alteração nas Características Físicas dos Solos Pós-Oxidação}

Os resultados dos ensaios granulométricos realizados após o período de oxidação do solo a partir da concentração inicial de $14 \mathrm{~g} / \mathrm{L}$ e uma relação de massa de persulfato e solo de $21 \mathrm{~g} / \mathrm{kg}$, indicaram nenhuma alteração significativa na distribuição percentual dos grãos (Figura 25). Sendo assim, verifica-se que a oxidação dos solos utilizados no ensaio de batelada não provocou qualquer alteração no tamanho das partículas sólidas. 


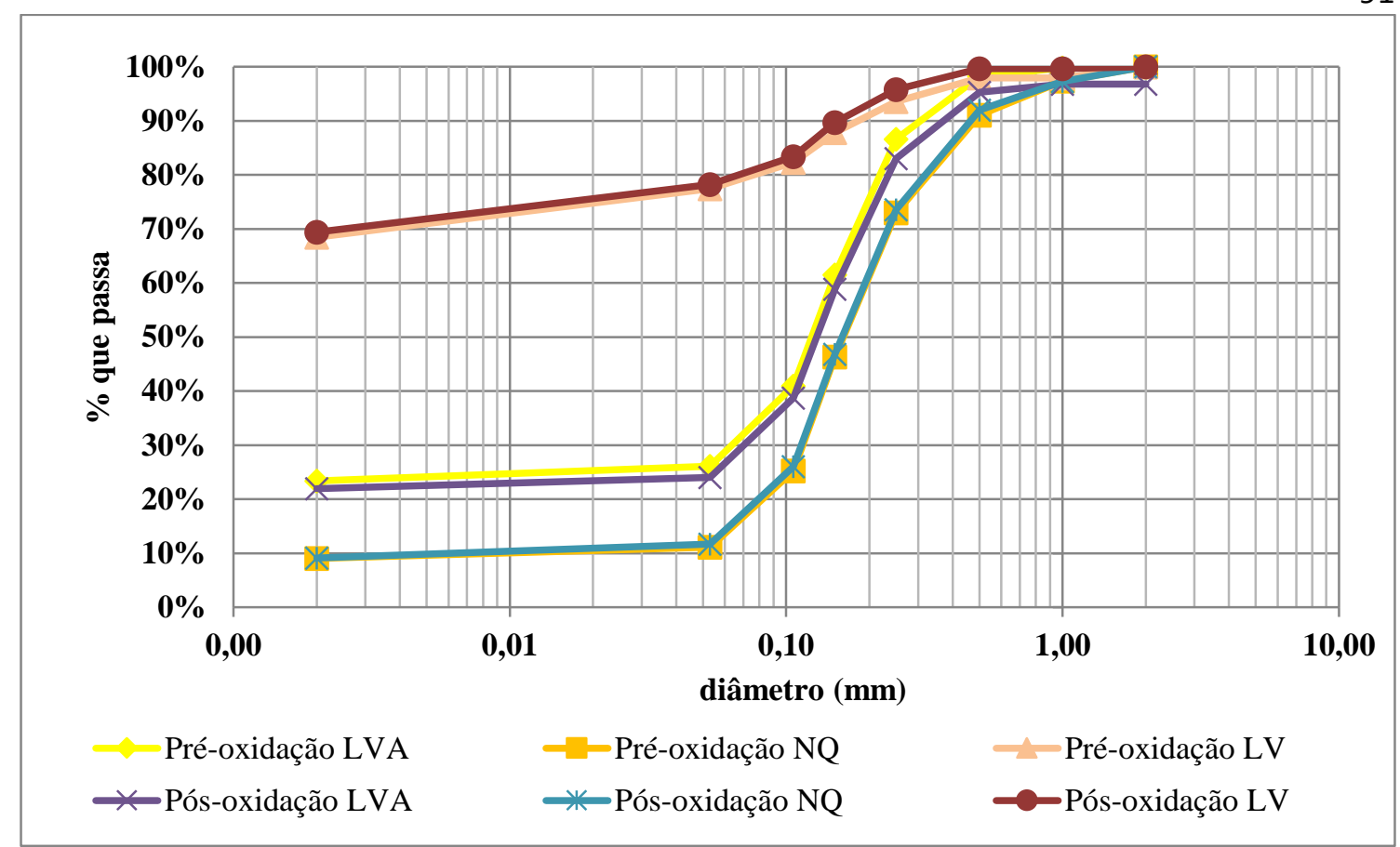

Figura 25 - Porcentagem de grãos que passam pela peneira.

Com a intenção de avaliar preliminarmente a alteração na condutividade hidráulica do solo devido à interação entre o solo e a solução de persulfato de potássio, após a determinação da condutividade das amostras indeformadas, algumas delas foram mantidas imersas em solução oxidante de 14 e 28g/L de persulfato e após aproximadamente 80 dias foram retiradas da solução e colocadas novamente no permeâmetro para determinação de nova condutividade hidráulica (Tabela 26).

Em duas amostras a condutividade hidráulica reduziu entre uma a duas ordens de grandeza após a oxidação. Entretanto, uma delas (2.3) teve este parâmetro elevado após o período de permanência na solução. Contudo, foi observada perda de solo na amostra 2.3, o que pode ter comprometido o resultado. A redução de condutividade hidráulica das amostras indeformadas mantidas em solução pode estar relacionada ao entupimento dos poros devido à dispersão da argila possivelmente causada por alterações nas cargas de superfície das partículas das amostras. Os resultados das análises químicas (item 4.8) indicaram mudanças nos parâmetros químicos das amostras que podem ter ocasionado alteração na estrutura física. 
Tabela 26 - Condutividade Hidráulica média da água nas amostras indeformadas antes e após testes preliminares de oxidação.

\begin{tabular}{|c|c|c|c|c|}
\hline \multirow[b]{2}{*}{ Amostra } & \multirow{2}{*}{$\underset{(\mathbf{g} / \mathbf{L})}{\mathbf{S}_{2} \mathbf{O}^{-}}$} & \multicolumn{2}{|c|}{ Condutividade Hidráulica (cm/s) } & \multirow[b]{2}{*}{$\Delta \mathbf{K}(\mathbf{c m} / \mathbf{s})$} \\
\hline & & Pré-oxidação & $\begin{array}{l}\text { Pós-oxidação } \\
(14 \mathrm{~g} / \mathrm{L})\end{array}$ & \\
\hline 1.2 & 14 & $3,11 \mathrm{E}-02$ & $3,96 \mathrm{E}-03$ & $-2,72 \mathrm{E}-02$ \\
\hline 1.4 & 28 & $2,93 \mathrm{E}-02$ & $9,64 \mathrm{E}-04$ & $-2,83 \mathrm{E}-02$ \\
\hline 2.3 & 28 & $5,29 \mathrm{E}-04$ & $2,71 \mathrm{E}-02$ & $2,65 \mathrm{E}-02$ \\
\hline
\end{tabular}

\subsection{Alteração nas Características Química dos Solos Pós-Oxidação}

A seguir são apresentados e discutidos os resultados referentes às análises químicas realizadas com as amostras de solo deformadas antes e após aproximadamente 120 dias de oxidação com solução de persulfato de $14 \mathrm{~g} / \mathrm{L}$.

\subsubsection{Cargas Elétricas do Solo, Carbono Orgânico e Inorgânico, e Extração Sequencial do Ferro}

As concentrações dos cátions e ânions determinados nas amostras de solo antes e após a oxidação são apresentadas na Tabela 27. Conforme descrito nesta tabela, a concentração de potássio trocável aumentou consideravelmente após a oxidação. Este aumento demonstra que o potássio adicionado no ensaio de batelada por meio da adição de solução de persulfato de potássio foi adsorvido na fração argila do solo carregado negativamente. Exceto a amostra NQ não apresentou elevação da concentração de potássio, pois este solo possui baixo teor de coloides no solo, sendo que apenas $8,7 \%$ da massa do solo corresponde a argila.

No geral foi observada redução da concentração de cálcio trocável, provavelmente substituído pelo potássio por troca catiônica. O contrário foi observado para a concentração de alumínio trocável $\left(\mathrm{Al}^{+3}\right)$ e $\mathrm{H}^{+}$. O alumínio presente inicialmente na estrutura do mineral pode ter sido mobilizado para a solução pela dissolução de um ou mais minerais e posteriormente foi retido na superfície do solo na forma trocável. Segundo Sposito, (1989) a o alumínio pode ser mobilizado tanto pela dissolução de hidróxidos de alumínio amorfo e cristalino em meio ácido quanto pela decomposição de caulinita em meio ácido. Segundo Lindsay (1979) a pH de máxima estabilidade da gibbsita é igual a 5,2 e, portanto, superior ao pH da solução após a adição de persulfato.

$\mathrm{O}$ aumento dos íons $\mathrm{H}^{+}$adsorvidos a superfície do solo é decorrente da acidificação provocada pela adição de persulfato, que pode ter sido substituído em parte pelo cátion potássio adicionado na solução devido à dissociação do sal persulfato de 
potássio, o potássio pode também ter ocupado os sítios de adsorção inicialmente ocupados pelo cálcio.

Tabela 27 - Resultados das concentrações de cátions trocáveis, nas amostras de TFSA do LVA, LV e NQ antes e após a oxidação.

\begin{tabular}{ccccccc}
\hline & & \multicolumn{5}{c}{$\mathbf{m m o l c} / \mathbf{k g}$} \\
\hline \multicolumn{1}{c}{ Solo } & Amostras & $\mathbf{K}^{+}$ & $\mathbf{C a}^{\mathbf{2 +}}$ & $\mathbf{M g}^{\mathbf{2 +}}$ & $\mathbf{A l}^{\mathbf{3 +}}$ & $\mathbf{H}^{+}$ \\
\hline \multirow{2}{*}{ LVA/ 0,7-0,85m } & pré-oxidação & $<0,2$ & 12 & 2 & 2 & 16,00 \\
\cline { 2 - 7 } & Pós-oxidação (C2) & 23,725 & 2 & $<1$ & 18,25 & 18,75 \\
\hline \multirow{2}{*}{ LV/ >0,85m } & pré-oxidação & 0,2 & 6 & 1 & 21 & 63,00 \\
\cline { 2 - 7 } & Pós-oxidação (C2) & 49,1 & $<2$ & $<1$ & 58 & 86,00 \\
\hline \multirow{2}{*}{ NQ/ > 1,37m } & pré-oxidação & $<0,2$ & $<1$ & 1 & 2 & 9,00 \\
\cline { 2 - 7 } & Pós-oxidação (C2) & $<0,3$ & $<2$ & $<1$ & 9,25 & 9,00 \\
\hline
\end{tabular}

Tanto a partir do pH medido em água quanto aquele aferido em solução salina de $\mathrm{KCl}$ pode-se observar a acidificação do solo após a oxidação (Tabela 28). A verificação da liberação de íons $\mathrm{H}^{+}$através da hidrólise do persulfato corrobora a compreensão a respeito da dissolução de hidróxidos de alumínio e da caulinita devido reações de hidrólise. Conforme apresentado anteriormente, a amostra de solo LV apresentou maior capacidade de tamponar a solução de persulfato de modo a evitar a acidificação da solução, sendo assim, acredita-se que o aumento na concentração de alumínio pode estar relacionado a dissolução da gibbsita bem como da caulinita. Esta dissolução mobilizou alumínio para a solução e posteriormente este pode ter sido adsorvido nas bordas dos argilominerais assim como os íons $\mathrm{H}^{+}$. A adsorção dos íons $\mathrm{H}^{+}$na superfície dos argilominerais resultaram na acidificação das amostras de solo.

Tabela 28 - Resultados do potencial hidrogeniônico das amostras de TFSA antes e após a oxidação.

\begin{tabular}{|c|c|c|c|c|}
\hline Solo & Identificação & pH (H2O) & $\mathrm{pH}(\mathrm{KCl})$ & $\Delta \mathrm{pH} *$ \\
\hline \multirow{2}{*}{ LVA/0,7-0,85m } & Pré-oxidação & 5,50 & 4,50 & $-1,00$ \\
\hline & Pós-oxidação (C2) & 4,27 & 4,05 & $-0,22$ \\
\hline \multicolumn{2}{|c|}{$\Delta$ pH [pH(pós) -pH (pré)] } & $-1,23$ & $-0,45$ & - \\
\hline \multirow{2}{*}{ LV/>0,85m } & Pré-oxidação & 4,90 & 4,20 & $-0,70$ \\
\hline & Pós-oxidação (C2) & 3,90 & 3,75 & $-0,15$ \\
\hline \multicolumn{2}{|c|}{$\Delta$ pH [pH(pós) -pH (pré)] } & $-1,00$ & $-0,45$ & - \\
\hline \multirow{2}{*}{$\mathrm{Nq} />1,37 \mathrm{~m}$} & Pré-oxidação & 5,10 & 4,30 & $-0,80$ \\
\hline & Pós-oxidação (C2) & 4,33 & 4,20 & $-0,13$ \\
\hline \multicolumn{2}{|c|}{$\Delta \mathrm{pH}[\mathrm{pH}($ pós) $-\mathrm{pH}$ (pré)] } & $-0,77$ & $-0,10$ & - \\
\hline
\end{tabular}

Meurer, (2010) comenta que as reações de hidrólise em meio ácido podem formar alguns monômeros do alumínio. A seguir são representados os monômeros de alumínio. 


$$
\begin{array}{cc}
\mathrm{Al}^{+3}+\mathrm{H}_{2} \mathrm{O} \rightarrow \mathrm{Al}(\mathrm{OH})^{+2} & \mathrm{pK}=4,97 \\
\mathrm{Al}(\mathrm{OH})^{2}+\mathrm{H}_{2} \mathrm{O} \rightarrow\left[\mathrm{Al}(\mathrm{OH})_{2}\right]^{+1} & \mathrm{pK}=4,93 \\
{\left[\mathrm{Al}(\mathrm{OH})_{2}\right]^{1+}+\mathrm{H}_{2} \mathrm{O} \rightarrow\left[\mathrm{Al}(\mathrm{OH})_{3}\right]^{0}} & \mathrm{pK}=5,7 \\
{\left[\mathrm{Al}(\mathrm{OH})_{3}\right]^{0}+\mathrm{H}_{2} \mathrm{O} \rightarrow\left[\mathrm{Al}(\mathrm{OH})_{4}\right]^{-1}} & \mathrm{pK}=7,4
\end{array}
$$

Desta forma, para valores de $\mathrm{pH}$ menores do que 4,97 a forma predominante do alumínio seria a forma solúvel $\left(\mathrm{Al}^{+3}\right)$. Neste estado o alumínio poderá ser lixiviado pelo solo. Em meios com pH inferior a 5,7 as formas observadas do alumínio apresentam toxicidade às plantas (MEURER, 2010). As forças de atração dos íons $\mathrm{H}^{+}$e $\mathrm{Al}^{+3}$ pelas superfícies dos óxidos, argilominerais e polímeros são forças de atração eletrostática em grupos $\mathrm{OH}^{-}$e $\mathrm{O}^{-2}$ (MELO, 1985 apud SILVA, 2006).

A Tabela 29 possui os resultados relativos a capacidade de troca catiônica das amostras de solo deformadas antes do processo de oxidação e após a oxidação com a maior concentração de persulfato. Nesta tabela está representada também a variação da CTC entre as amostras pré-oxidadas e pós-oxidadas.

Com base nos resultados, verifica-se que a variação entre a CTC das amostras pré e pós-oxidação apresentaram variação expressiva, sendo a máxima observada para as amostras do LV. Sendo assim, acredita-se que eventualmente a oxidação possa resultar em golfos de dissolução da caulinita ou ainda de hidróxidos de alumínio e por consequência ocasionar maiores imperfeições na superfície do mineral aumentando assim sua capacidade em adsorver cátions. As cargas adicionais eventualmente formadas devido a oxidação serão variáveis, de superfície podendo assim variar conforme a variação do pH. Por outro lado, o método analítico utilizado para determinação da CTC pode ter resultado falso positivo em relação ao aumento da CTC, já que foi empregado o método de CTC efetiva ao invés da CTC total.

O aumento da CTC do solo tende a favorecer a retenção de cátions do solo, evitando assim a perda dos nutrientes do solo os quais podem ser facilmente lixiviados. Contudo, se os sítios de adsorção estiverem preenchidos por $\mathrm{H}^{+}$ou $\mathrm{Al}^{3+}$, o aumento observado na CTC não será vantajoso para a fertilidade do solo. Para verificar a influência destes cátions deve-se avaliar os resultados da saturação por bases (SB), porcentagem da saturação por bases (V\%) e por alumínio (m\%) já que é possível observar se o ambiente se encontra tóxico as plantas. 
Tabela 29 - Capacidade de Troca Catiônica das amostras deformadas antes e após a oxidação.

\begin{tabular}{cccc}
\hline \multirow{2}{*}{ Amostras } & \multicolumn{3}{c}{ CTC mmolc/kg } \\
\cline { 2 - 4 } & Pré-oxidação & Pós-oxidação $(\mathbf{C 2})$ & $\mathbf{\Delta C T C}^{(\mathbf{1})}$ \\
\hline LVA/0,7-0,85m & 32,7 & 63 & 30,3 \\
\hline LV/>0,85m & 91,3 & 194,9 & 103,6 \\
\hline Nq/>1,37m & 11,7 & 28,55 & 16,85 \\
\hline
\end{tabular}

(1) Diferença entre CTC da amostra pré-oxidação e pós-oxidação.

De acordo com os resultados relativos a saturação por base (Tabela 30), verifica-se que após a oxidação a amostra do LV apresentou aumento significativo em relação a este parâmetro e reduziu em $22 \%$ a saturação por alumínio. Logo, a oxidação do solo reduziu a ocupação do alumínio pelos sítios de adsorção de cátions presentes nas partículas coloidais. O mesmo pode ser observado nas amostras do NQ a qual teve um aumento em $22,5 \%$ na saturação por base e uma redução de $18 \%$ na saturação por alumínio. A redução da percentagem de alumínio na CTC deve-se pelo aumento dos sítios de adsorção ocupados pelo o potássio.

Tabela 30 - Saturação de base (SB), porcentagem da saturação por base (V) e porcentagem da saturação por alumínio $(\mathrm{m} \%)$ das amostras de solo antes e após a oxidação.

\begin{tabular}{ccccccc}
\hline \multirow{2}{*}{ Amostras } & \multicolumn{3}{c}{ Pré-oxidação } & \multicolumn{3}{c}{ Pós-oxidação (C2) } \\
\cline { 2 - 7 } & $\begin{array}{c}\text { SB } \\
(\mathbf{m m o l c} / \mathbf{k g})\end{array}$ & $\mathbf{V} \%$ & $\mathbf{m} \%$ & $\begin{array}{c}\text { SB } \\
(\mathbf{m m o l c} / \mathbf{k g})\end{array}$ & $\mathbf{V} \%$ & $\mathbf{m} \%$ \\
\hline LVA/0,7-0,85m & 14,2 & 44,0 & 12,0 & 25,85 & 39,5 & 43,0 \\
\hline LV/>0,85m & 7 & 8,0 & 75,0 & 51,1 & 26,0 & 53,0 \\
\hline NQ/> 1,37m & 1,1 & 10,0 & 68,0 & 9,95 & 32,5 & 50,0 \\
\hline
\end{tabular}

Com base nos resultados de variação da CTC, da saturação por bases e alumínio acredita-se que a oxidação provocou alteração na estrutura do mineral de modo a mobilizar o alumínio para a solução do solo o qual pode ser em seguida adsorvido a superfície do solo. Desta forma, a oxidação química por persulfato em solos brasileiros ricos em argilomineral 1:1 e hidróxidos de alumínio poderá causar a mobilização deste elemento e dependendo das condições do meio o metal poderá ser lixiviado para água subterrânea ou permanecer adsorvido a superfície do mineral por forças de atração eletrostática.

Apesar da hipótese de os minerais serem capazes de acelerar a depleção do persulfato e/ou ativar a reação, deve-se atentar a participação da fração orgânica. Sendo assim, conforme apresentado na Tabela 31 verifica-se que a fração de carbono orgânico não foi responsável pela depleção de persulfato em solução em contato com as amostras de solo LV e LVA já que não houve alteração significativa na concentração de carbono 
orgânico após a oxidação. Em relação a depleção do persulfato em contato com o NQ, verifica-se que houve participação significativa do carbono orgânico pois, houve redução de aproximadamente 52\% na concentração de carbono orgânico para esta amostra após a oxidação. Apesar de não ter sido observada alteração significativa na fração de carbono orgânico para as amostras LV e LVA, a regressão linear entre os valores de carbono orgânico de cada solo e as constantes da taxa de reação apresentaram correlação equivalente a 1 . Nenhuma das amostras analisadas apresentaram carbono inorgânico.

O carbono orgânico nos Latossolos analisados pode não ter sido oxidado devido à presença de complexos organo-minerias formado entre o composto orgânico e os óxidos de ferro. A ausência de concentrações significativas de óxido de ferro no NQ pode ter favorecido o ataque do persulfato no composto orgânico deste solo.

Tabela 31 - Concentração de Carbono Orgânico nas amostras pré e pós oxidação.

\begin{tabular}{cccc}
\hline \multirow{2}{*}{ Solo } & Pré-oxidação & Pós-oxidação & \multirow{2}{*}{$\Delta \mathbf{C}(\mathbf{g} / \mathbf{k g})$} \\
\cline { 2 - 3 } & Carbono Orgânico $(\mathrm{g} / \mathrm{kg})$ & Carbono Orgânico $(\mathrm{g} / \mathrm{kg})$ & \\
\hline LVA & $2,33 \pm 0,32$ & $2,42 \pm 0,30$ & $0,09 \pm 0,62$ \\
\hline LV & $16,70 \pm 1,05$ & $15,36 \pm 1,01$ & $-1,34 \pm 2,06$ \\
\hline NQ & $1,47 \pm 0,31$ & $0,70 \pm 0,02$ & $-0,77 \pm 0,33$ \\
\hline
\end{tabular}

O persulfato em contato com o LVA e NQ não foi capaz de alterar as formas de ferro nas diferentes frações analisadas (Tabela 32). Contudo, para as amostras do LV, que apresentou maior concentração e ferro e maior constante de taxa de reação, houve alteração significativa na concentração de ferro após a oxidação especialmente nas frações ligadas a óxidos de ferro amorfo e cristalino (Tabela 32) indicando assim acentuada interação do ferro com o persulfato. Devido à elevada concentração de ferro no LV, pode ter sido formado radicais sulfato e/ ou persulfato na solução. A correlação obtida para a fração de ferro amorfo e total das amostras e as constantes da taxa de reação foi semelhante a 1 . Não apenas a concentração de ferro presente no solo pode ter sido determinante para a maior interação do LV com o persulfato, mas forma predominante de ferro no solo. Conforme comentado anteriormente, o LV apresenta maior concentração de hematita do que goethita enquanto que o LVA ocorre o inverso. Sendo assim, é possível que a interação do persulfato tenha sido maior com o ferro trivalente presente na hematita do que o ferro bivalente presente na goethita.

A fração de ferro ligado aos óxidos amorfos diminuiu 2,5 vezes e a fração ligada aos óxidos cristalinos aumentou 4 vezes. $O$ ferro pode ter permanecido parte em solução formando assim os radicais livres de sulfato e posteriormente persulfato, mas outra parte 
pode ainda ter sido precipitada na forma de ferro cristalino (Figura 26). A destruição da caulinita pode ter favorecido o aumento na concentração de ferro ligado aos óxidos cristalinos. Esta interação entre o persulfato e o ferro presente nos óxidos e eventualmente na caulinita pode ter sido responsável pelo decaimento inicial mais acelerado do persulfato. Já que o brusco decaimento do $\mathrm{pH}$ da solução pode ter favorecido a dissolução dos minerais.

Ainda em relação aos resultados relativos a amostra LV, acredita-se que provavelmente houve a mobilização do ferro inicialmente ligado a matéria orgânica para a fração trocável, pois houve aumento na concentração de ferro ligado a fração trocável e redução na fração ligada a matéria orgânica. Sendo assim, apesar do persulfato não ter oxidado significativamente o carbono orgânico em contato com o LV, ele pode interagir com a fração orgânica do solo de modo a mobilizar metais inicialmente adsorvidos a fração orgânica devido a acidificação da solução. Ressalta-se ainda que parte da fração trocável do ferro pode ter sido oxidada e precipitada. A Figura 26 ilustra a interação do persulfato e o LV.

Tabela 32 - Concentração de ferro trocável, ligado a matéria orgânica, aos óxidos e concentração total de ferro nas amostras após a oxidação e variação das concentrações das amostras pré e pós oxidação.

\begin{tabular}{|c|c|c|c|c|c|c|c|c|c|}
\hline \multirow{3}{*}{ Frações } & \multicolumn{9}{|c|}{ Concentração de Ferro (mg/Kg) } \\
\hline & \multicolumn{3}{|c|}{ LVA } & \multicolumn{3}{|c|}{ NQ } & \multicolumn{3}{|c|}{$\mathrm{LV}$} \\
\hline & Pré & Pós & $\Delta \mathrm{Fe}$ & Pré & Pós & $\Delta \mathrm{Fe}$ & Pré & Pós & $\Delta \mathrm{Fe}$ \\
\hline Trocável & $\begin{array}{l}11 \\
\pm 2\end{array}$ & $\begin{array}{l}13 \\
\pm 1\end{array}$ & 2,5 & $\begin{array}{c}9 \\
\pm 1\end{array}$ & $\begin{array}{c}8 \\
\pm 1\end{array}$ & -1 & $\begin{array}{c}4,8 \\
\pm 0,2\end{array}$ & $\begin{array}{l}12 \\
\pm 1\end{array}$ & 6,7 \\
\hline Matéria Orgânica & $\begin{array}{l}30 \\
\pm 4\end{array}$ & $\begin{array}{l}30 \\
\pm 2\end{array}$ & $-0,4$ & $\begin{array}{l}27 \\
\pm 1\end{array}$ & $\begin{array}{l}29 \\
\pm 2\end{array}$ & 1,6 & $\begin{array}{l}42,2 \\
\pm 1,9\end{array}$ & $\begin{array}{l}28 \\
\pm 1\end{array}$ & $-13,9$ \\
\hline Óxidos Amorfos & $\begin{array}{l}5.830 \\
\pm 410\end{array}$ & $\begin{array}{l}5.358 \\
\pm 178\end{array}$ & -475 & $\begin{array}{l}4.550 \\
\pm 334\end{array}$ & $\begin{array}{l}4.833 \\
\pm 216\end{array}$ & 283 & $\begin{array}{l}76.158 \\
\pm 6.600\end{array}$ & $\begin{array}{l}30.650 \\
\pm 5.157\end{array}$ & 45.508 \\
\hline Óxido Cristalino & $\begin{array}{l}3.730 \\
\pm 600\end{array}$ & $\begin{array}{l}3.850 \\
\pm 235\end{array}$ & 117 & $\begin{array}{l}2.192 \\
\pm 495\end{array}$ & $\begin{array}{l}2.629 \\
\pm 176\end{array}$ & 438 & $\begin{array}{l}16.970 \\
\pm 3.632\end{array}$ & $\begin{array}{l}70.125 \\
\pm 3.363\end{array}$ & 53.155 \\
\hline Total & 16.280 & 15.982 & -293 & 10.704 & 11.555 & 851 & 93.175 & 148.406 & 55.231 \\
\hline
\end{tabular}




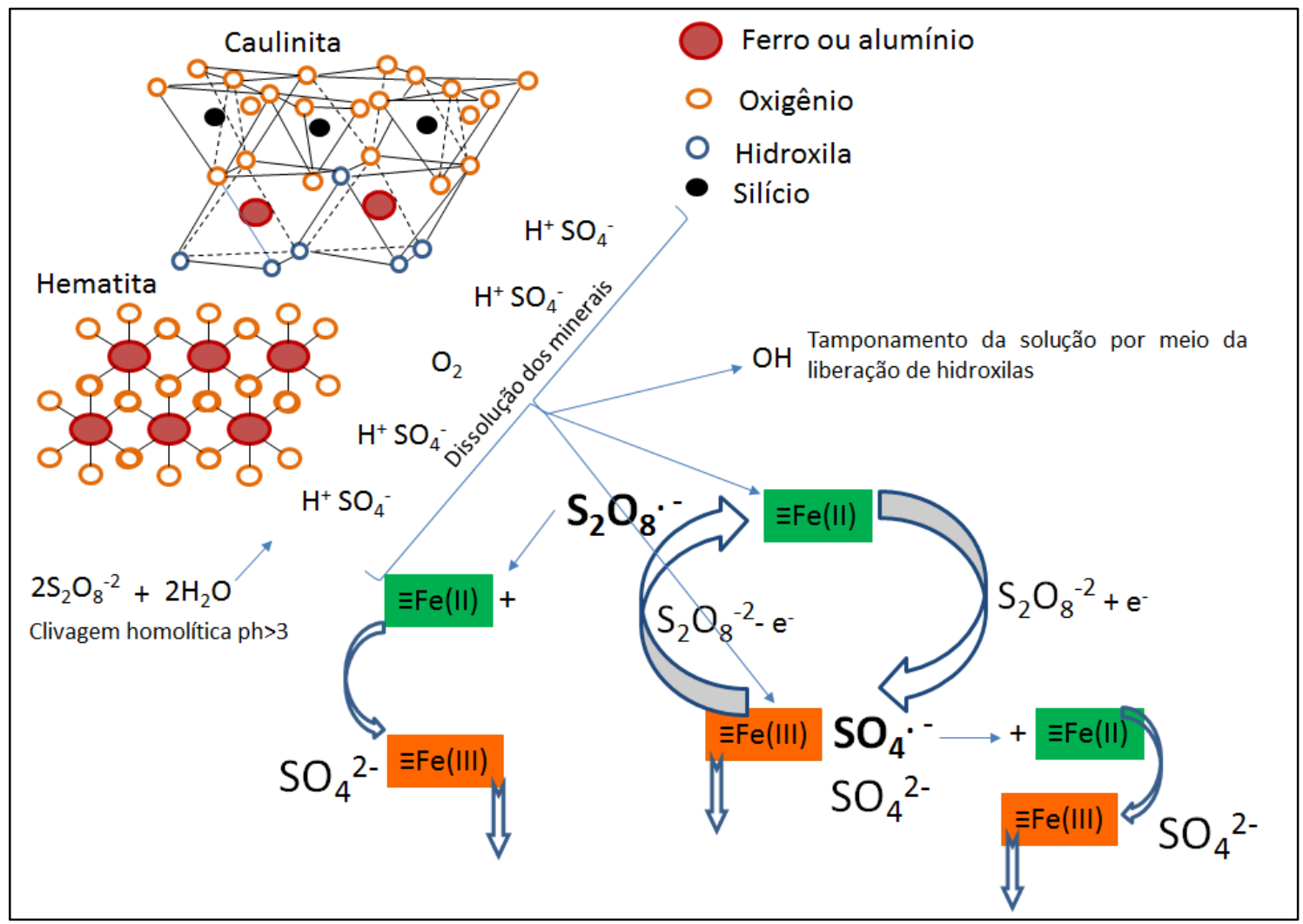

Figura 26: Esquematização da interação do persulfato com o LV.

\subsection{Alteração na Mineralogia}

Devido a acidificação da solução nos ensaios de batelada, acredita-se que a capacidade do LV em tamponar a solução favoreceu a dissolução de alguns minerais. Para avaliar esta hipótese, fez-se a leitura da difração de raio-x da argila total das amostras dos solos oxidadas a uma concentração inicial equivalente a $14 \mathrm{~g} / \mathrm{L}$ e em seguida os resultados obtidos foram comparados com os resultados relativos a caracterização das amostras antes da oxidação.

Comparando a intensidade relativa dos picos das amostras LVA e NQ (Figura 27 e Figura 28) não é observada formação de novos minerais após a oxidação, contudo houve redução nos picos referente a caulinita e gibbsita. Já os difratogramas relativos à amostra LV (Figura 29) apresentam redução nos picos da caulinita, gibbsita e hematita e aumento de outros picos, os quais não foram identificados.

Os óxidos de ferro encontrados predominantemente nos Latossolos são a goethita e a hematita (FONTES \& WEED, 1991). Considerando que o LV foi o solo que mais interagiu com o persulfato, é provável que dentre estes dois óxidos de ferro, a hematita tenha sido o óxido que mais interagiu com o persulfato, favorecendo a formação de radicais livres e também a degradação do oxidante. 
Segundo Ker (1997) os cristais da hematita possuem menor estabilidade do que os da goethita. Schwertmann (1991) verificou que a hematita dissolve preferencialmente do que a goethita em amostras de solo com a misturas desses minerais. De acordo com o autor na dissolução ácida, as reações se iniciam pela formação de complexos nos sítios superficiais, em sequência pelo enfraquecimento das ligações Fe-O e deslocamento do ferro para a solução (INDA JUNIOR e KAMPF, 2005a; INDA JUNIOR e KAMPF, 2005b). Contudo, em Latossolos torna-se difícil a avaliação da dissolução destes óxidos devido a heterogeneidade dos minerais goethita e hematita já que devido ao longo período de formação destes minerais e das diversas variáveis climáticas relacionadas a sua formação, diferentes gerações de goethita e hematita são formadas (INDA JUNIOR e KAMPF, 2005).

Além disso, salienta-se que as amostras utilizadas na análise por difração de raio-X correspondem a fração da argila total o que dificulta a avaliação das alterações causadas nos picos referentes aos óxidos devido à presença dos filossilicatos.

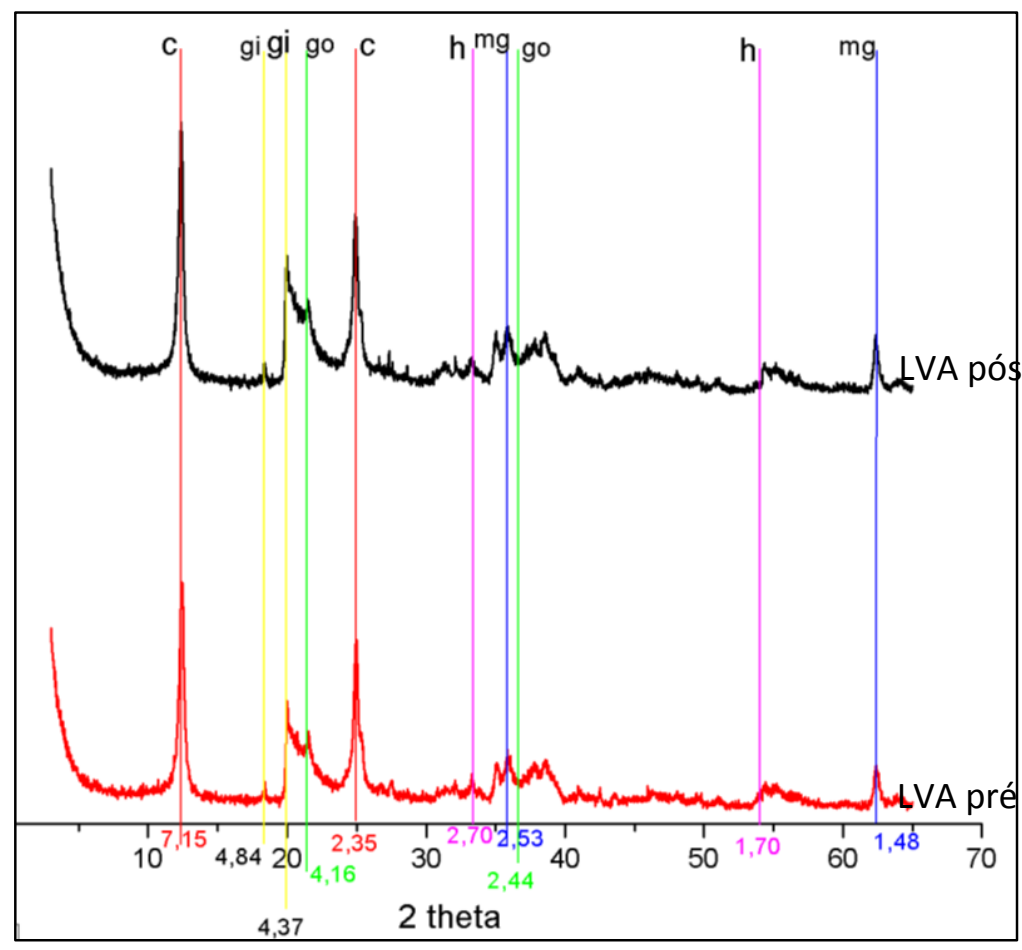

c: Caulinita; gi: Gibbsita; go: Goethita; h: Hematita; mg: Magnetita.

Figura 27 - Difratogramas do LVA antes e após a oxidação do solo com concentração inicial de 14g/L. 


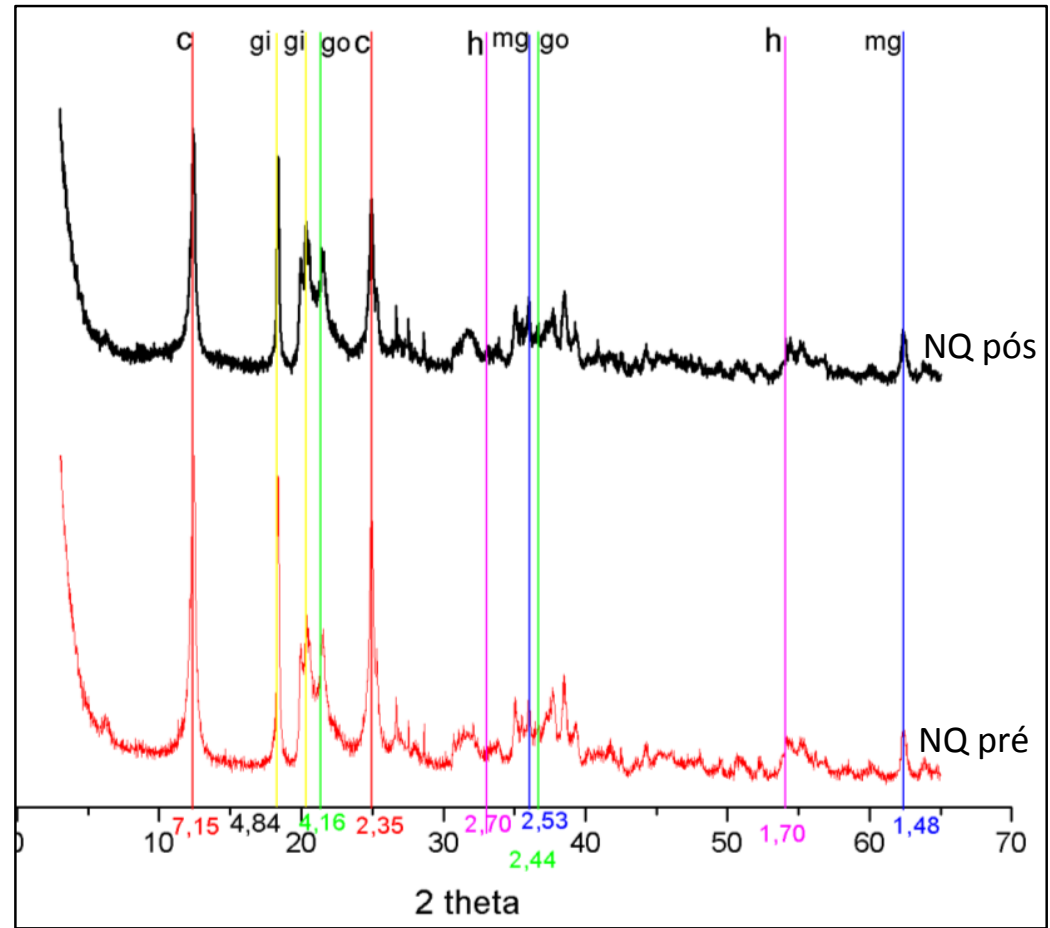

c: Caulinita; gi: Gibbsita; go: Goethita; h: Hematita; mg: Magnetita.

Figura 28 - Difratogramas do NQ antes e após a oxidação do solo com concentração inicial de 14g/L.

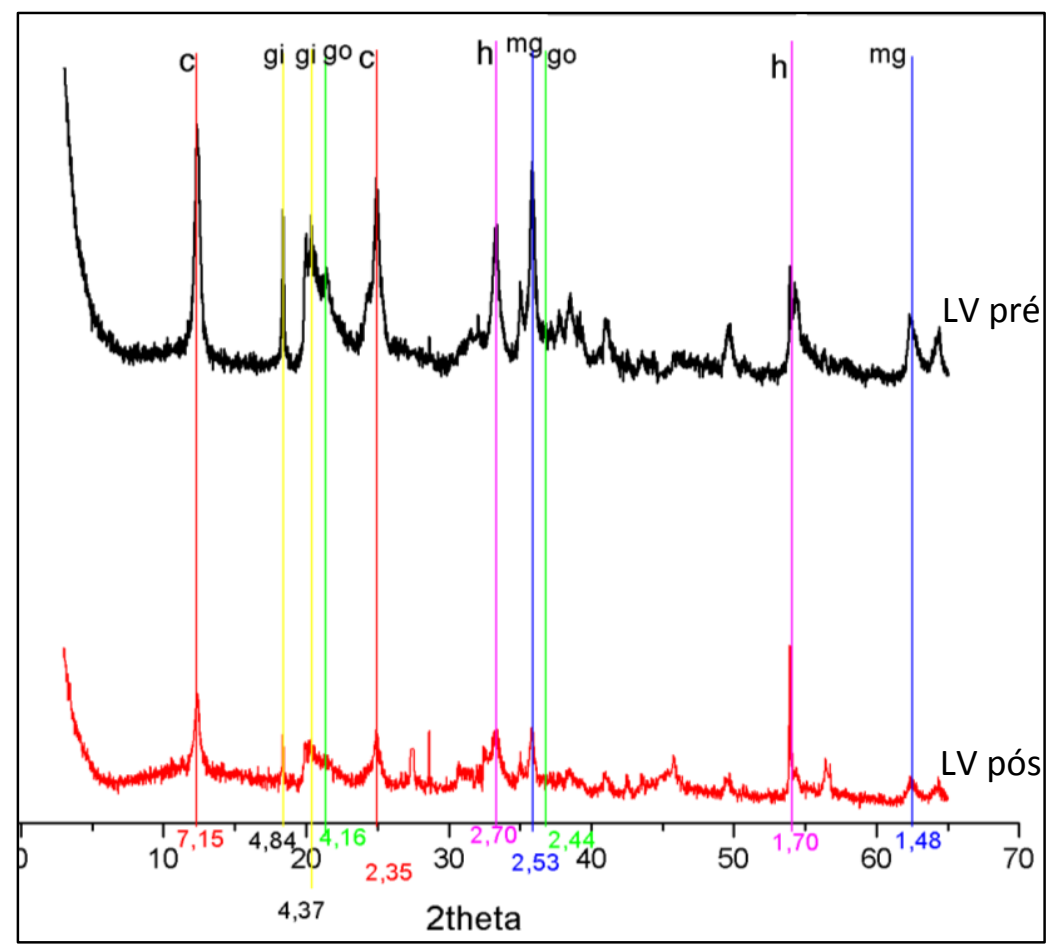

c: Caulinita; gi: Gibbsita; go: Goethita; h: Hematita; mg: Magnetita.

Figura 29 - Difratogramas do LV antes e após a oxidação do solo com concentração inicial de 14g/L. 
A fim de avaliar quantitativamente a redução dos minerais em especial da caulinita e da gibbsita utilizou-se a análise termogravimétrica (Figura 30 a Figura 32). Os resultados da análise térmica das amostras comprovam a redução da concentração de caulinita e gibbisita nas amostras após a oxidação do solo por período de aproximadamente 120 dias a uma concentração inicial de 14g/L (Tabela 33). Dentre as amostras oxidadas a que deteve maior redução na concentração de caulinita e gibbsita foi a amostra de solo LV. A amostra LVA teve a segunda maior redução de caulinita enquanto que a amostra NQ teve a segunda maior redução de gibbsita. Contudo, a não desferrificação das amostras antes da análise térmica pode ter ocasionado interferências na quantificação. A Figura 30 a Figura 32 possuem as curvas de termogravimétricas (TG) e as curvas DTA de cada uma das amostras analisadas.

Tabela 33 - Concentração de caulinita e gibbisita na fração argilosa das amostras pré e pós-oxidação.

\begin{tabular}{cccc|ccc|cccc}
\hline & \multicolumn{3}{c|}{ LVA } & \multicolumn{3}{c|}{ LV } & \multicolumn{4}{c}{ NQ } \\
\cline { 2 - 10 } Mineral & Pré & Pós & $\Delta$ & Pré & Pós & $\Delta$ & Pré & Pós & $\Delta$ \\
\hline $\begin{array}{c}\text { Caulinita } \\
(\mathrm{g} / \mathrm{kg})\end{array}$ & 570 & 478 & $-16,2 \%$ & 464 & 267 & $-42,5 \%$ & 393 & 347 & $-11,71 \%$ \\
\hline $\begin{array}{c}\text { Gibbisita } \\
(\mathrm{g} / \mathrm{kg})\end{array}$ & 51 & 40 & $-22,3 \%$ & 92 & 34 & $-62,7 \%$ & 125 & 96 & $-23,15 \%$ \\
\hline
\end{tabular}

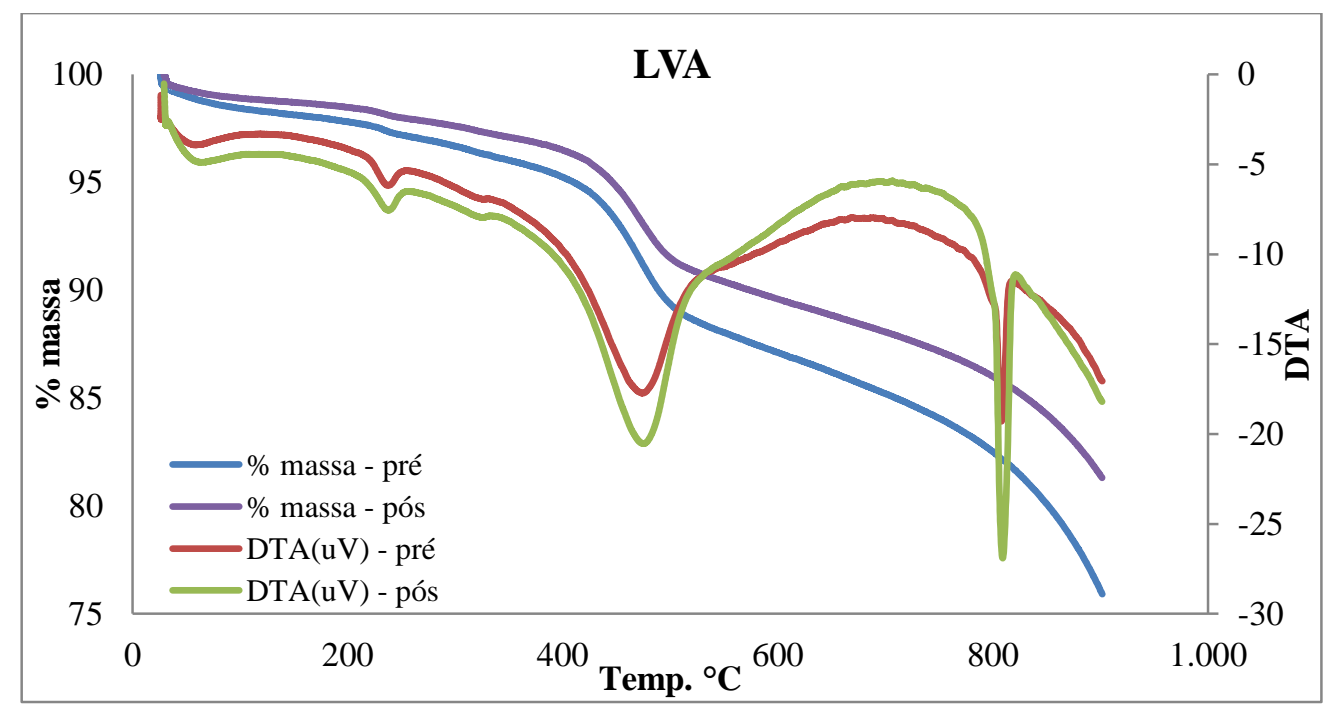

Figura 30 - TG e DTA amostras LVA pré e pós oxidação. 


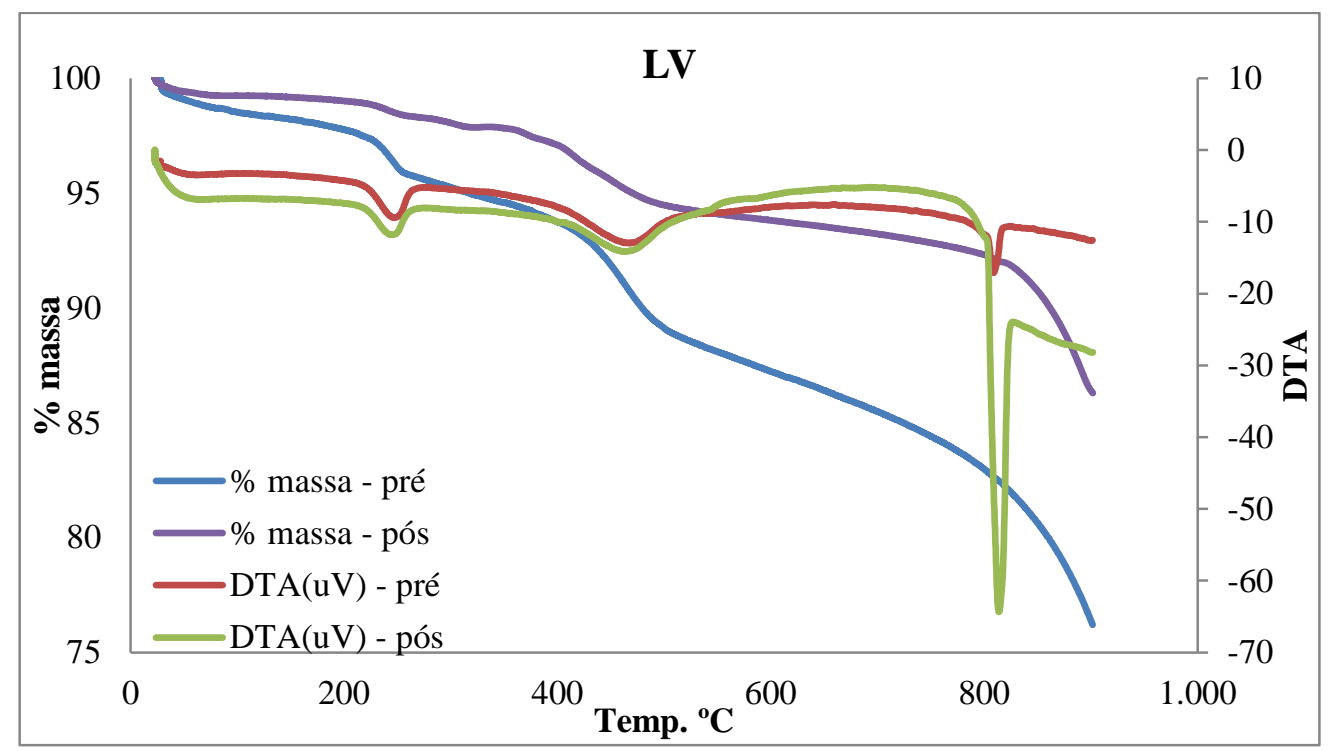

Figura 31 - TG e DTA amostras NQ pré e pós oxidação.

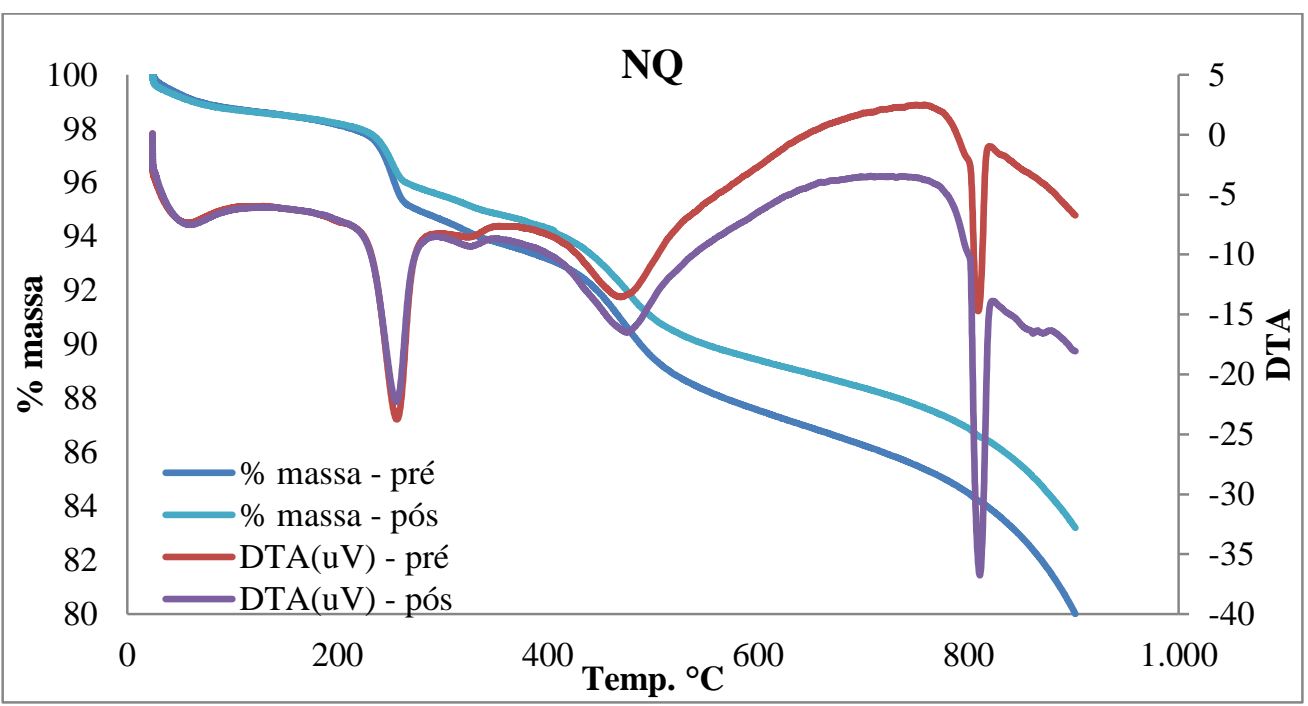

Figura 32 - TG e DTA amostras NQ pré e pós oxidação. 


\subsection{Oxidação do Latossolo Vermelho em Coluna Indeformada}

Com intuito de avaliar o transporte da solução oxidante e eventuais alterações nas propriedades hidráulicas do solo, ensaios de oxidação com coluna unidimensional foram realizados durante período de 30 dias. O solo selecionado para os ensaios com coluna foi o LV já que este apresentou maior interação com a solução oxidante durante o ensaio por batelada e consequentemente maior capacidade de depleção do oxidante injetado. Além disso, o LV foi selecionado por ser o solo classificado como zonal com características específicas, típicas de região de clima tropical úmido. Ensaios com coluna devem ser confeccionados para avaliação da taxa de degradação do persulfato, pois permitem melhor aproximação às condições reais observadas em campo durante o processo de oxidação.

\subsubsection{Avaliação do Traçador Conservativo - Fluoresceína}

Inicialmente são apresentados os resultados do ensaio realizado em coluna deformada para seleção do traçador conservativo.

A fluoresceína sódica foi o primeiro traçador injetado na coluna deformada afim de avaliar se o mesmo poderia ser retardado pelo solo. Considerando a velocidade da água pela coluna, foi possível estabelecer o tempo de saída necessário. Contudo, foi possível observar que a fluoresceína não poderia ser utilizada como traçador conservativo já que foi totalmente retardada pelo solo. Essa observação foi confirmada pois após a injeção de um volume equivalente a 2 volumes de poros de $114 \mathrm{mg} / \mathrm{L}$ de fluoresceína não foi detectada nenhuma concentração de fluoresceína na saída da coluna. Desta forma, a utilização do sal orgânico, fluoresceína sódica, como traçador conservativo foi descartada.

\subsubsection{Avaliação do Traçador Conservativo - Brometo}

A utilização do brometo como traçador conservativo mostrou-se satisfatória já que não houve retardamento na saída do traçador e o modelo de Ogata \& Banks (1961) se ajustou aos dados aferidos e plotados (Figura 33). A velocidade do traçador obtida a partir do modelo analítico foi semelhante a velocidade da água, confirmando assim a ausência de retardamento. 


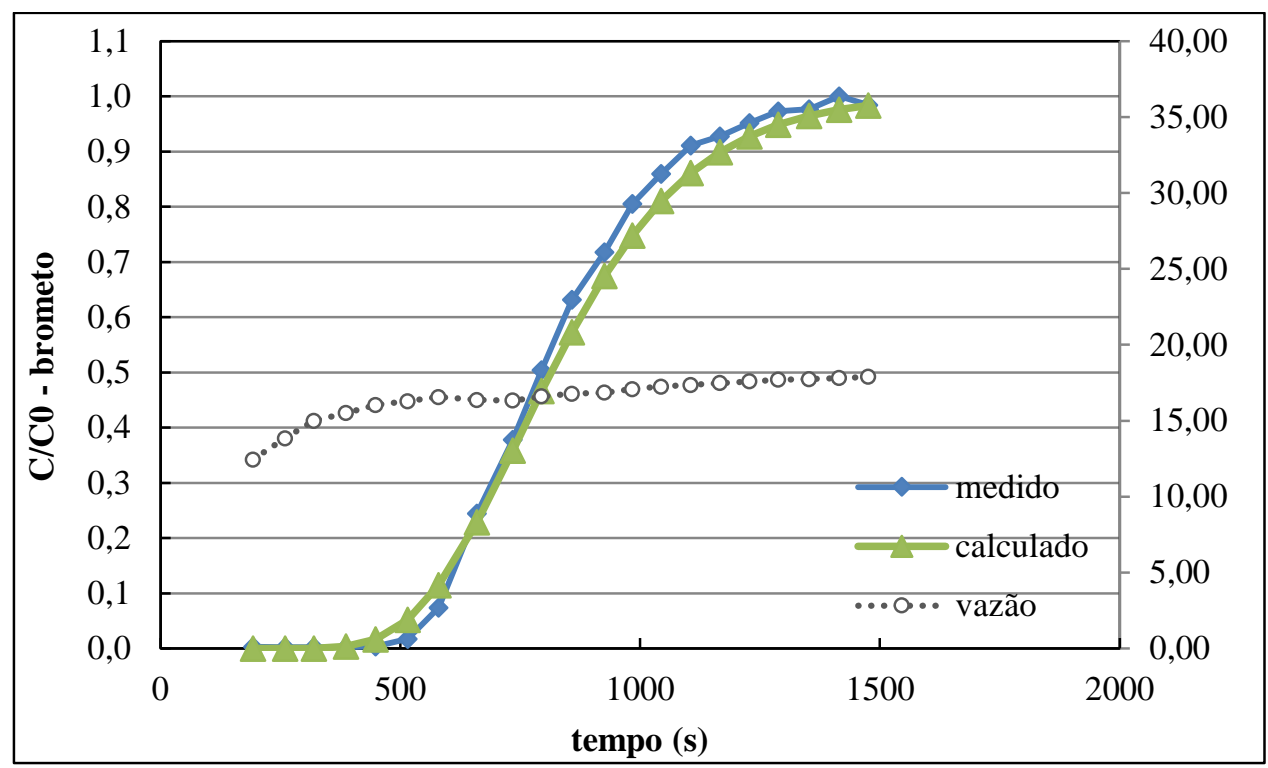

Figura 33 - Concentrações relativas de Brometo aferidas na saída da coluna deformada.

Considerando a velocidade da frente de fluxo calculada a partir da razão entre a distância percorrida pelo traçador e tempo para que C/C0 seja igual a 0,5 na saída da coluna (eq. 34) foi possível calcular a velocidade média do deslocamento do traçador de $1,54 \mathrm{~cm} / \mathrm{min}$.

$$
v=\frac{x}{t(C / C 0)=0,5}=\frac{22,0 \mathrm{~cm}}{14,3 \mathrm{~min}}
$$

Levando em consideração que a velocidade média da água que passa pelos poros é a razão entre o volume que escoa num determinado tempo (vazão) e o produto da seção de área (A) por onde escoa o fluido e a porosidade (eq. 35) foi possível verificar que a velocidade média da água é equivalente a $1,62 \mathrm{~cm} / \mathrm{min}$. Sendo assim verifica-se que a diferença entre a velocidade média da água obtida por meio da amostra coletada com anel volumétrico e calculada através da equação 35 e aquela obtida por meio de ensaios preliminares com o brometo (eq. 34) teve diferença de apenas 5\%. Esta diferença pode ainda estar relacionada a alteração da porosidade já que foi utilizada coluna deformada para os ensaios preliminares com o traçador.

$$
\boldsymbol{v}=\frac{Q}{\boldsymbol{A} \times \boldsymbol{n}}
$$

$Q=16,5 \mathrm{~cm}^{3} / \mathrm{min}$

$A=15,21 \mathrm{~cm}^{2}$

$\mathrm{n}=67 \%$

Com o valor do coeficiente de dispersão hidrodinâmica e velocidade do fluxo da água calculado a partir dos ensaios com a coluna deformada, e considerando o valor do 
coeficiente de difusão efetivo do brometo na água calculado por Shackelford e Daniel (1991) $\left(\mathrm{De}=2,02 \times 10^{-5} \mathrm{~cm}^{2} / \mathrm{s}\right)$, calculou-se a dispersividade do meio (eq. 36).

$$
\alpha(\mathbf{c m})=\frac{\mathrm{D} l-\mathrm{D}^{*}}{v}
$$

A dispersividade calculada a partir dos ensaios preliminares apresentaram valores de $0,86 \mathrm{~cm}$ para a amostra LV. Segundo Assis e Lanças, (2005), as características do solo que poderiam alterar a condutividade hidráulica seriam a porosidade total, a distribuição de tamanho dos poros e a tortuosidade dos interstícios. Sendo assim, a fim de avaliar eventuais alterações na condutividade hidráulica do meio causadas pela oxidação que consequentemente poderiam prejudicar a remediação, colunas com amostras de solo indeformadas foram preparadas.

\subsubsection{Coluna Indeformada}

Após a definição das dimensões da coluna a ser confeccionada para a coleta das amostras de LV de modo que não houvesse compactação ou ainda que está fosse o mínimo possível, fez-se a coleta em campo com 2 colunas (Coluna 1 e Coluna 2) de aço com $20 \mathrm{~cm}$ de comprimento e $10 \mathrm{~cm}$ de diâmetro. A compactação da Coluna 1 foi equivalente a $22 \%$ e a da Coluna 2 foi de $21 \%$, sendo assim a porosidade do solo da Coluna 1 e 2 passaram respectivamente para aproximadamente 54 e $49 \%$.

Feita a saturação da coluna conforme indicado no Item 3.8.1, passou-se o traçador conservativo para a obtenção do coeficiente de dispersão, bem como para determinação da velocidade do fluxo da água, da dispersividade e porosidade do solo. As Figuras 34 e 35, apresentam a curva de breakthrough obtidas no segundo e terceiro ensaio da Coluna 1 antes da oxidação. Para a Coluna 1 foram realizados três ensaios, sendo que o primeiro foi desconsiderado e para a Coluna 2 apenas um o qual mostrou-se satisfatório (Figura 35). No eixo da abcissa encontram-se os números de poros, os quais foram calculados por meio da divisão entre o volume injetado no instante " $t$ " e o volume total de poros da coluna. No eixo da ordenada estão plotados os valores da razão entre a concentração no instante " $t$ ” (C) e a concentração inicial (C0). Quando o volume injetado é equivalente a 1 volume de poros, a concentração na saída é igual a metade da concentração de entrada (Figura 35 e 37). Acredita-se que houveram erros na leitura da concentração de brometo da Coluna 1 durante a realização dos ensaios com o traçador conservativo já que as curvas de Breakthrough (Figura 34) não foram satisfatórias. Já a curva da Coluna 2 mostrou-se satisfatória já no primeiro teste (Figura 36). 


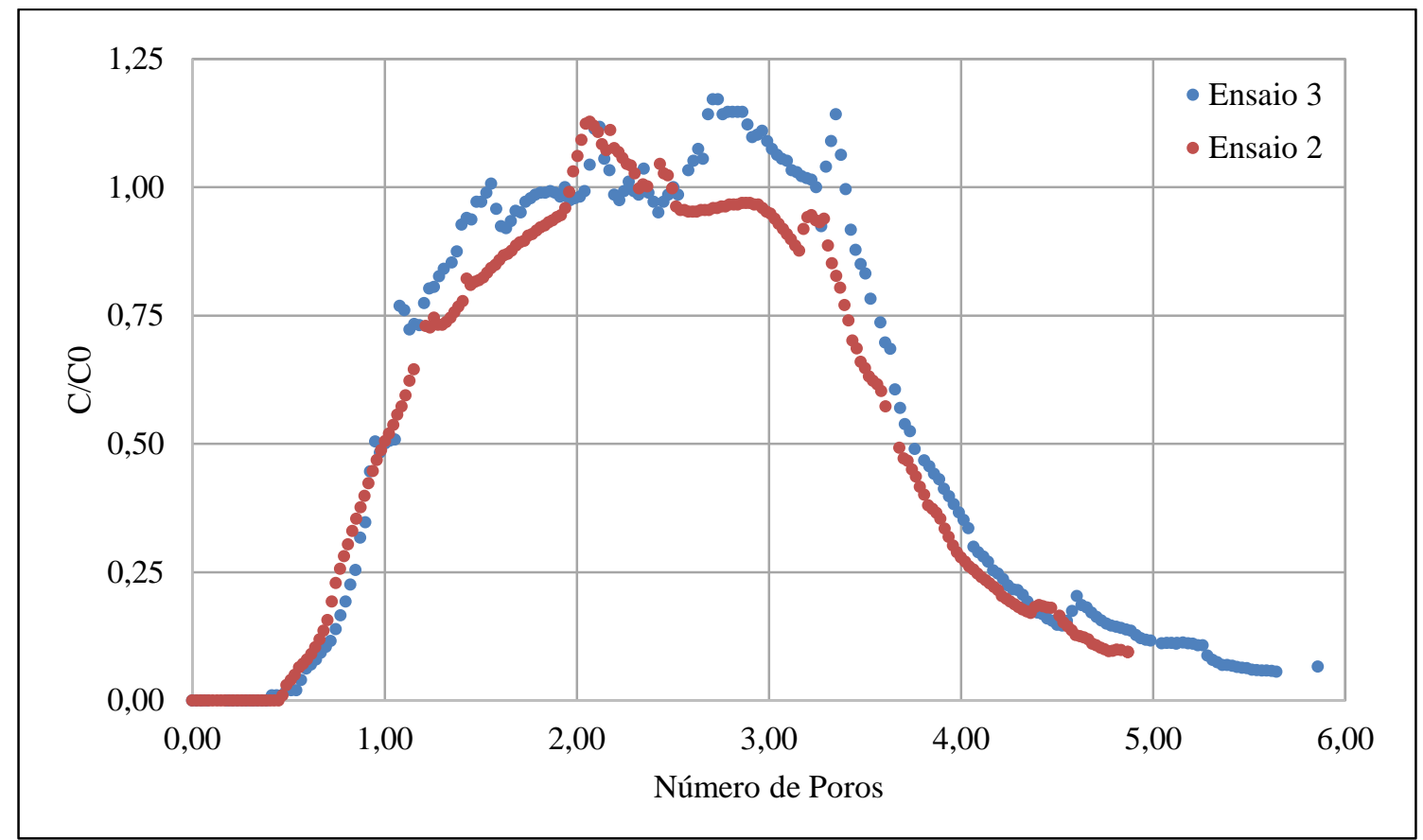

Figura 34 - Breakthrough brometo - Coluna 1 (Pré oxidação).
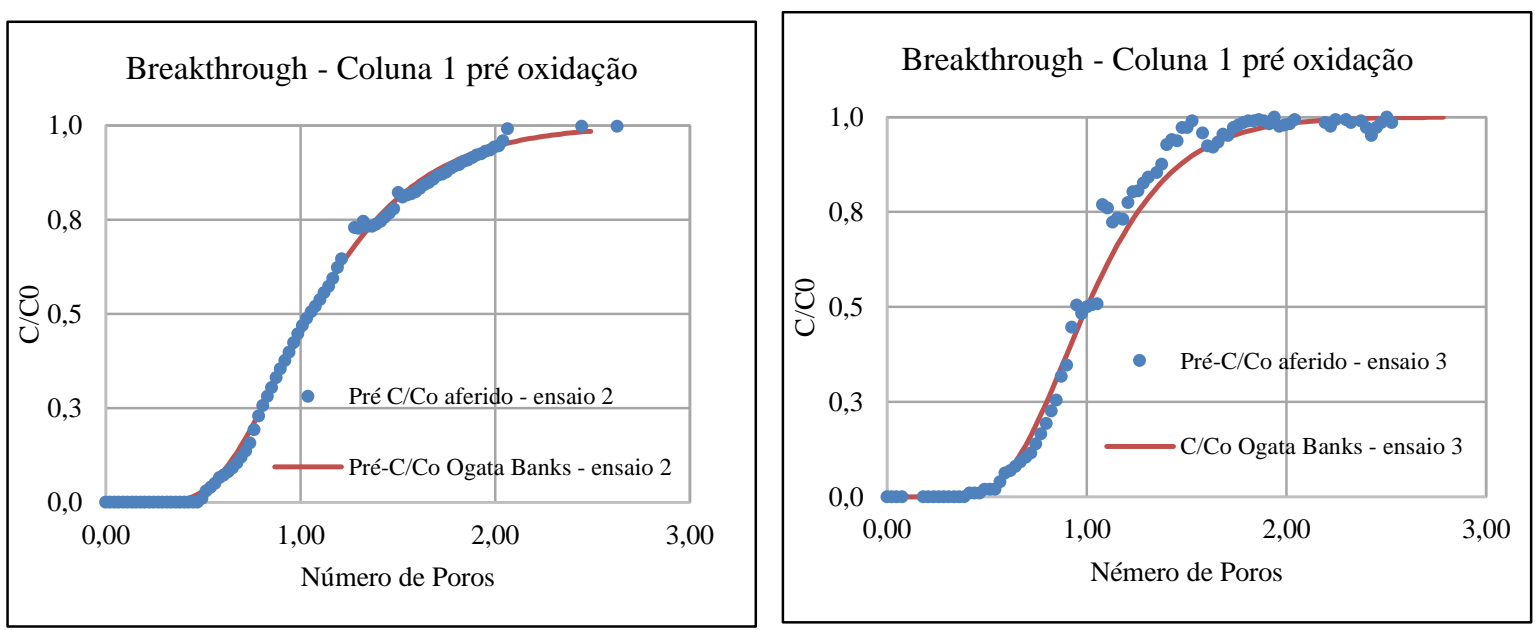

Figura 35 - Breakthrough brometo pré-oxidação Coluna 1, aferido e calculado com modelo Ogata e Banks. 


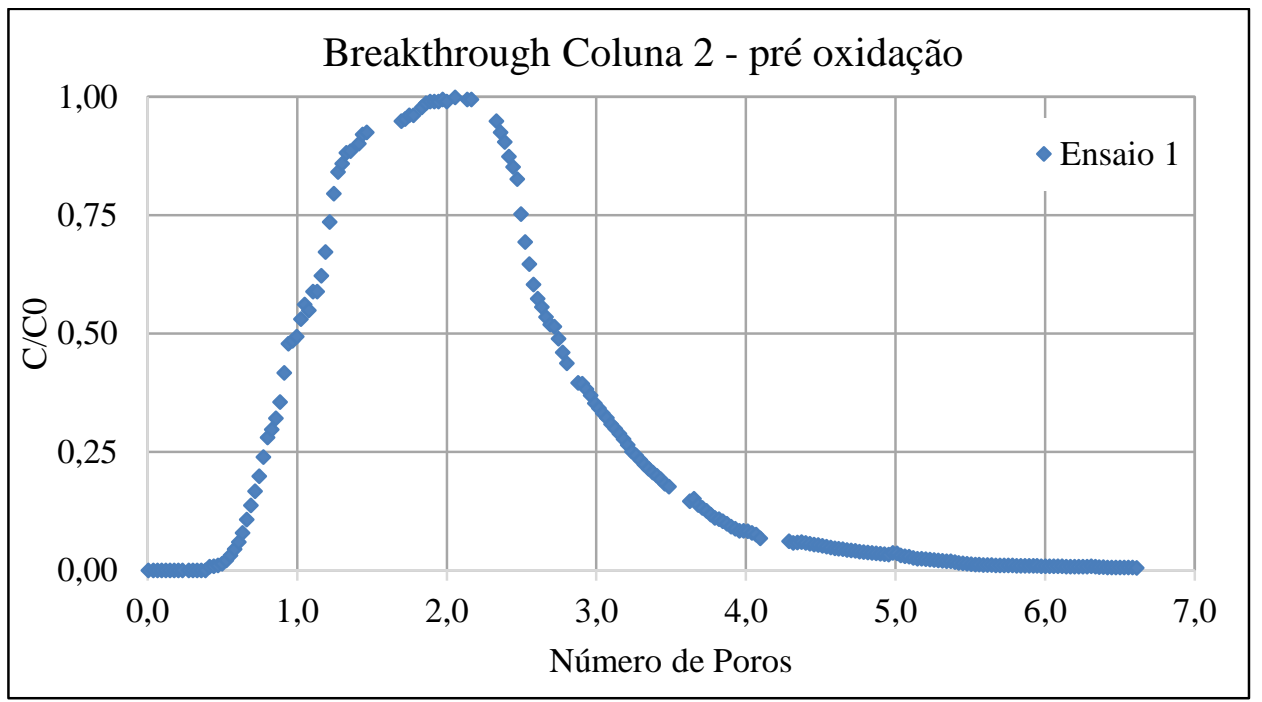

Figura 36 - Breakthrough brometo - Coluna 2 (Pré oxidação).

Ainda de acordo com a Figura 33 e 35, verifica-se que a subida e a descida da concentração de brometo não apresentaram simetria. O formato de "cauda" no final da curva provavelmente é devido a difusão intraagregados do brometo nos aglomerados de argila.

Para obtenção do coeficiente de dispersão plotou-se os dados de subida do traçador pela Coluna 1(Figura 34) e Coluna 2 (Figura 37) juntamente com o modelo de Ogata e Banks para fluxo com uma direção com advecção e dispersão (DOMENICO e SCHWARTZ, 1998). O modelo de Ogata e Banks é ajustado aos dados aferidos por meio da variação do coeficiente de dispersão, sendo que coeficientes mais elevados descrevem meios com maior dispersão e consequentemente a curva mostra-se mais inclinada. Por outro lado, quando a dispersão tende a zero, a curva se aproxima ao modelo advectivo, ou seja, a inclinação da curva também tenderá a zero.

O coeficiente de dispersão obtido para a Coluna 1, para uma vazão de injeção da solução de $30 \pm 1,5 \mathrm{~mL} / \mathrm{h}$ foi equivalente a 2,8E-02 e 1,9 E-02 cm$/ 2 / \mathrm{min}$ para os ensaios 2 e 3, respectivamente. Para a Coluna 2, o coeficiente foi equivalente a $1,50 \mathrm{E}-02 \mathrm{~cm}^{2} / \mathrm{min}$, sendo que a vazão de injeção foi a mesma utilizada na Coluna 1.

Em estudo realizado por Williams (2007), o coeficiente de dispersão obtido para material coletado no aquífero de Borden composto por areia fina a média inconsolidada foi equivalente a $5 \times 10^{-5} \mathrm{~cm}^{2} / \mathrm{min}$, sendo que a vazão de injeção adotada pelo autor assim como a velocidade média do fluxo foram as mesmas utilizadas para os ensaios com as colunas indeformadas do presente estudo. 


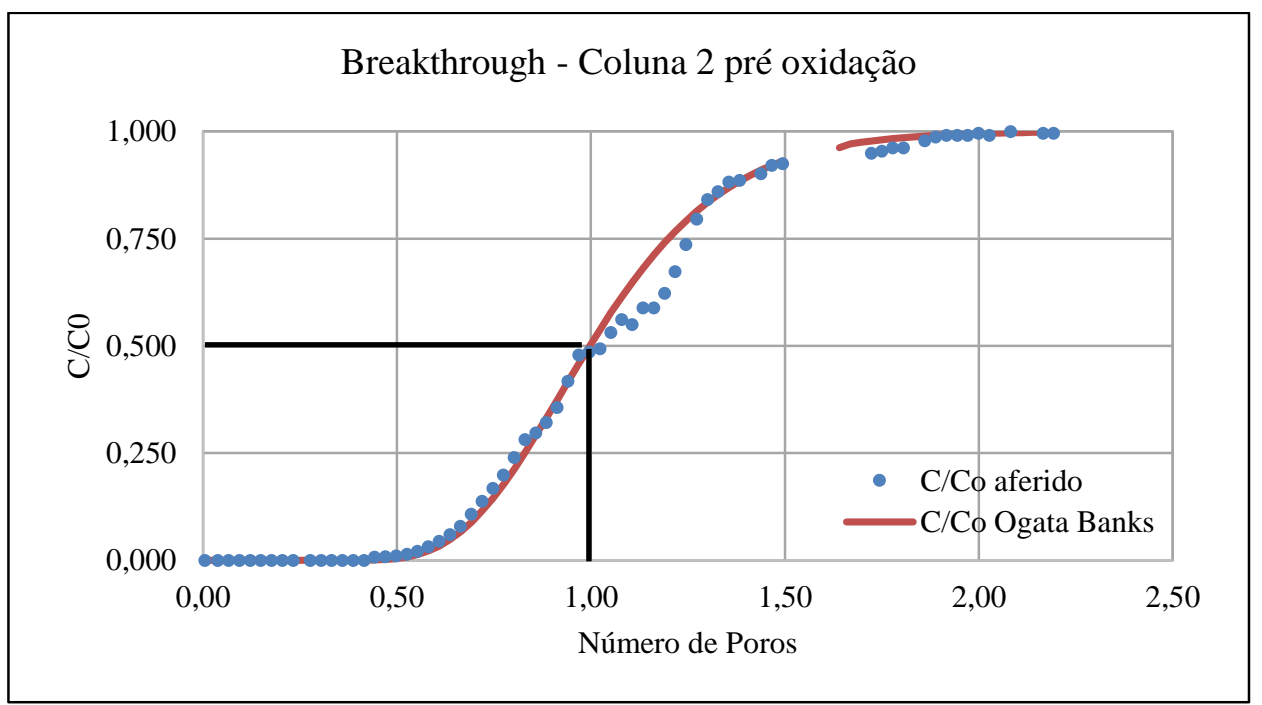

Figura 37 - Breakthrough brometo pré-oxidação Coluna 2, aferido e calculado com modelo Ogata e Banks.

A dispersividade obtida para as amostras de solo da Coluna 1 e 2 foram respectivamente semelhantes a 1,24 e $0,73 \mathrm{~cm}$. Desta forma, verifica-se que a dispersividade dos poros do Latossolo Vermelho foi respectivamente para a Coluna $1 \mathrm{e}$ 2; 20 e 12,6 vezes maior do que a dispersividade do aquífero de Borden $(0,06 \mathrm{~cm})$ no município de Ontario no Canadá. Ressalta-se ainda que a dispersividade obtida para a coluna deformada $(0,83 \mathrm{~cm})$ apresentou diferença de 30 e $18 \%$ em relação ao valor obtida para a Coluna indeformada 1 e 2 , respectivamente.

Para garantir que não houve retenção da massa de brometo, ou seja, a massa de brometo na entrada foi igual a massa de brometo na saída, comparou-se a massa na entrada (eq.37) e a massa na saída. A massa na saída foi calculada por meio da integral da curva da concentração de brometo versus o tempo e vazão (eq. 39). Com base nos cálculos, o erro entre a massa de entrada e saída foi equivalente a 3\% para o ensaio 2 da Coluna 1, 12\% para o ensaio 3 da Coluna 1 e ensaio 1 da Coluna 2.

$$
\begin{gathered}
M_{\text {entrada }}=Q_{\text {entrada }} \times t_{\text {injeção }} \times C_{0} \\
M_{\text {saída }}=\sum_{0}^{t}\left(C_{t_{\frac{\Delta t}{2}}} \times Q \times \Delta t\right)
\end{gathered}
$$

Se, $\Delta t \rightarrow 0$

$$
M(\text { saída })=Q \cdot \int_{0}^{t} C \cdot d t
$$

A porosidade das colunas foi calculada a partir da equação 35 já que era conhecida a vazão de injeção $(30 \mathrm{~mL} / \mathrm{h})$, a seção de área da coluna perpendicular ao sentido do fluxo e a velocidade do fluxo da água a qual foi obtida pela razão entre comprimento do 
deslocamento da frente de fluxo e o tempo de viagem quando $\mathrm{C} / \mathrm{C} 0$ era igual a 0,5. A porosidade da Coluna 1 e 2 foi respectivamente igual a 37 e $35 \%$, ou seja, porosidade diferente daquela esperada considerando o valor da porosidade obtido nas amostras indeformadas coletadas com anel volumétrico $(61,8 \%)$ e a compactação do solo gerada nas colunas no momento da coleta, a qual foi de aproximadamente $20 \%$. Esta diferença pode estar relacionada a heterogeneidade do solo.

\subsection{Interação do Oxidante e os Solos - Ensaio com Coluna Indeformada.}

O fluxo adotado para o ensaio foi fluxo continuo já que no ensaio de batelada o decaimento de persulfato foi acentuado. As Figuras 38 e 39 apresentam as curvas de breakthrough do persulfato obtidas para a Coluna 1 e 2 , respectivamente.

Conforme apresentado na curva de breakthrough de persulfato para a Coluna 1 (Figura 38), aproximadamente até as $100 \mathrm{~h}$ iniciais do ensaio, ou seja, passados um volume equivalente a 5 número de poros, a concentração de persulfato elevou-se até $\mathrm{C} / \mathrm{C} 0$ igual 1. Devido à reação do persulfato com o solo, não era esperado que a concentração na saída fosse igual à de entrada. Acredita-se que algum erro experimental na determinação da concentração de entrada tenha resultado em C/C0 igual a 1 na saída da coluna. Desta forma, a constante da taxa de reação da Coluna $1\left(0,009 \mathrm{~d}^{-1}\right)$ não é representativa para o solo.

Já na Coluna 2 (Figura 39) cuja concentração injetada foi de 9g/L, entre as 20 e as 100 horas iniciais, a concentração de persulfato teve o comportamento de subida diferentes daquele observado para as 20 primeiras horas, acredita-se que neste momento iniciou o processo de dissolução dos minerais. Após as 140h iniciais, ou seja, 8 números de poros, a concentração do persulfato estabilizou num intervalo de concentração equivalente a 65 e $80 \%$ do inicial, coerente com um modelo de decaimento de primeira ordem. Mesmo após 30 dias de oxidação, a concentração de saída da Coluna 2 não atingiu a concentração de entrada, indicando assim que os componentes responsáveis pela demanda do solo por oxidante não podem ser considerados finitos e, portanto, não é possível calcular a demanda total. A constante da taxa de reação da Coluna 2 foi equivalente a $0,400 \mathrm{~d}^{-1}$. 


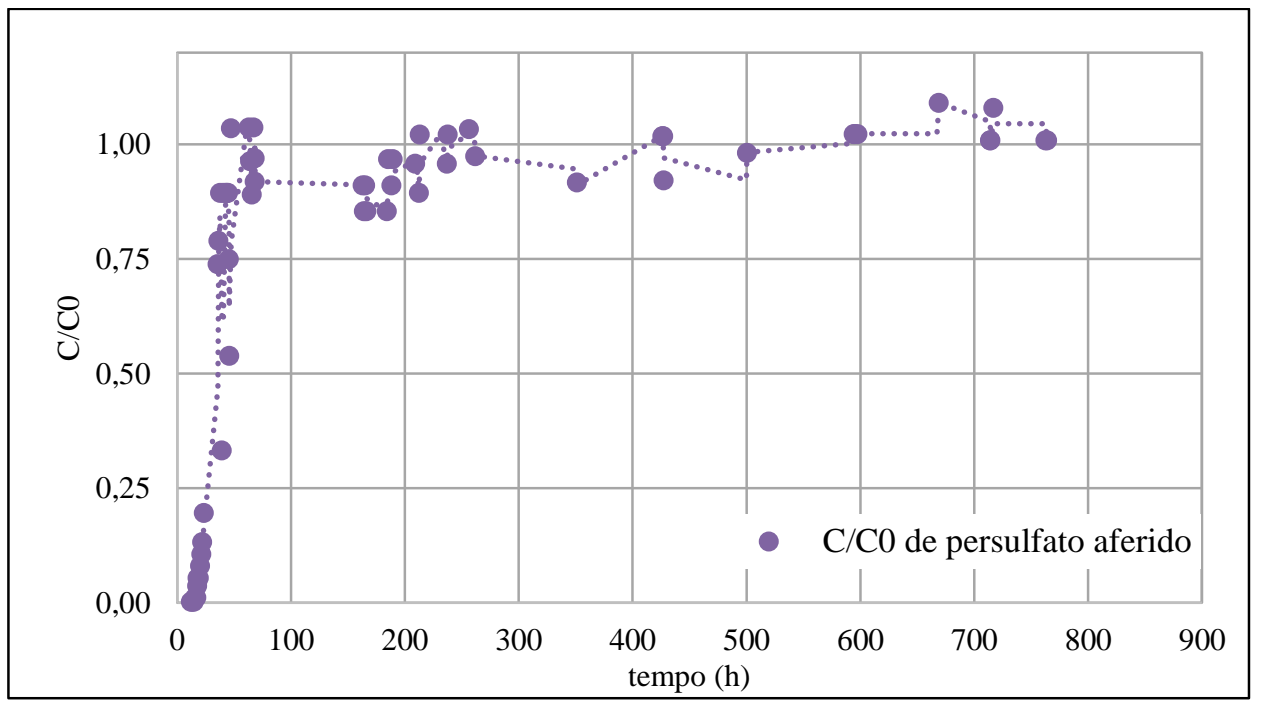

Figura 38 - Curva de Breakthrough de persulfato aferido na Coluna 1.

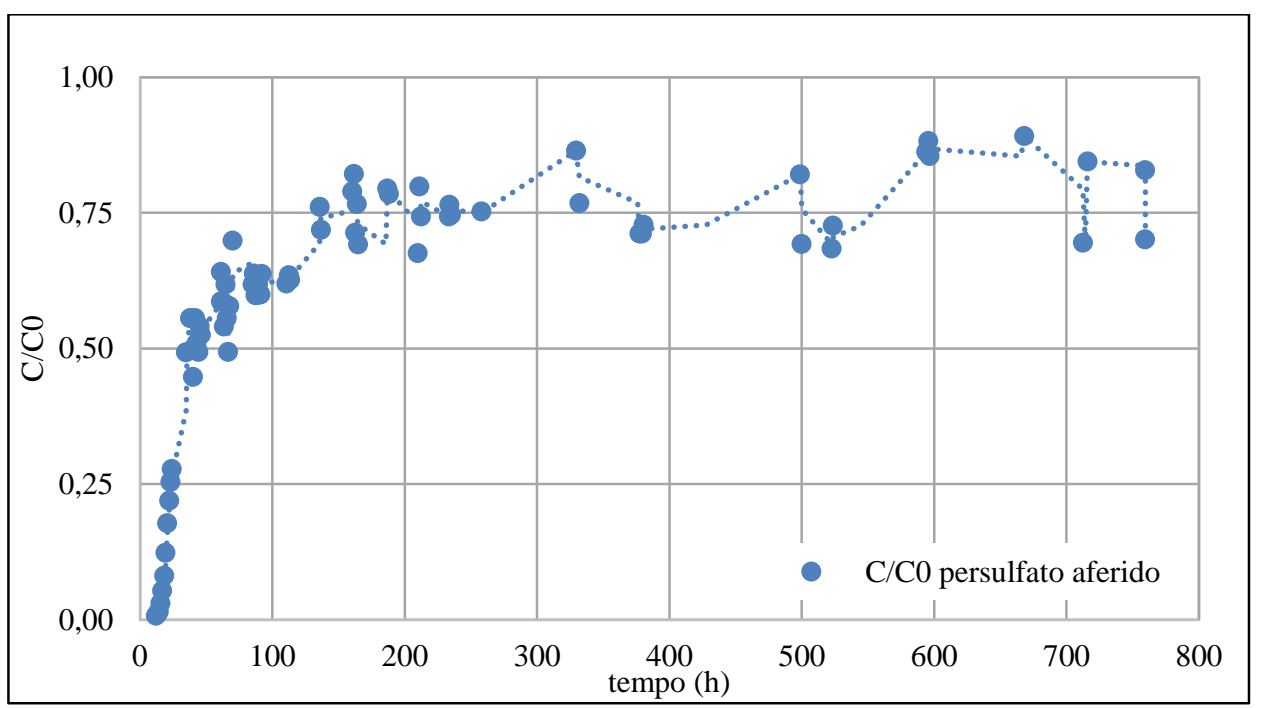

Figura 39 - Curva de Breakthrough de persulfato aferido na Coluna 2.

O tempo de viagem obtido para a Coluna 1 e 2 foram iguais a 19,5 e 18 horas, respectivamente. Com os tempos de viagem e com os valores de $\mathrm{C} / \mathrm{C} 0$ estabilizado nas curvas de breakthrough do persulfato da Coluna 1 e 2 (1 e 0,74; respectivamente) foi possível calcular os valores das constantes da taxa da reação os quais foram equivalentes a $9 \times 10^{-3} \mathrm{~d}^{-1}$ para a Coluna 1 e $4 \times 10^{-1} \mathrm{~d}^{-1}$ para a Colunas 2. Comparando os valores das constantes determinadas experimentalmente a partir do ensaio de batelada e a partir do ensaio com coluna indeformada, verificou-se que a constante obtida no ensaio com a Coluna 1 (concentração inicial de $14 \mathrm{~g} / \mathrm{L}$ ) e com a Coluna 2 (concentração inicial de $9 \mathrm{~g} / \mathrm{L}$ ) foram respectivamente 0,5 e 22,89 vezes maior do que a constante determinada a partir dos experimentos por batelada cuja concentração inicial fora $14 \mathrm{~g} / \mathrm{L}$. O valor obtido para Coluna 1 entretanto não condiz com o real devido a erro na determinação da 
concentração de C/C0. Segundo Sra et al. (2010), a relação entre as constantes da taxa de reação calculadas através de ensaios com coluna e batelada utilizando solo coletado na América do Norte estariam relacionados com a relação entre a massa de sólidos e o volume da solução destes sistemas conforme apresentado na eq (40):

$$
\frac{k^{\text {col. }}}{k^{\text {bat. }}}=\left(\frac{M \text { sólidos }^{\text {col. }} / \text { Vol solução }^{\text {col. }}}{M \text { sólidos }^{\text {bat. }} / V_{\text {ol solução }} o^{\text {bat.. }}}\right)^{1,5}
$$

Sendo,

$\frac{k^{c o l .}}{k^{\text {bat. }}}$ : relação entre a constante da taxa de reação obtida no ensaio com coluna e ensaio por batelada;

M sólidos: massa de sólido;

Vol solução: volume da solução.

Entretanto, esta correlação não se mostrou verdadeira para as amostras de solo utilizadas neste estudo já que o resultado do lado direito da eq. 40 foi aproximadamente $10^{2}$ vezes menor do que a razão entre as constantes da Coluna 2 e o ensaio de batelada. Contudo, salienta-se que a concentração inicial para a Coluna 2 foi igual a $9 \mathrm{~g} / \mathrm{L}$ ao invés de $14 \mathrm{~g} / \mathrm{L}$. As características entre os sólidos utilizados pelos autores citados e a presente pesquisa são extremamente diferentes, de modo que no geral os modelos e as premissas adotadas para interpretação da interação entre o solo e o persulfato podem não ser verdadeiras.

As constantes das taxas de reação obtidas para o LV por meio do ensaio com a Coluna 2 e o ensaio de batelada apresentaram a seguinte correlação com a massa de sólidos e o volume da solução eq. (41).

$$
\frac{k^{\text {col. }}}{k^{\text {bat. }}}=\left(\frac{M \text { sólidos }^{\text {col. }} / \text { Vol solução }^{\text {col. }}}{M \text { sólidos }^{\text {bat. }} / \text { Vol solução }^{\text {bat.. }}}\right)^{-1,9}
$$

A mesma correlação não foi verdadeira para a constante obtida na oxidação do solo da Coluna 1 e no experimento por batelada devido a problemas experimentais ocorridos durante o experimento com a Coluna 1.

Considerando a equação do transporte de massa (eq. 42) e a solução do modelo para apenas uma direção, apresentada por Genuchten e Alves (1982) (eq. 43) foi possível obter o fator de retardamento para o persulfato através do ajuste da solução do modelo nos dados aferidos. Para a Coluna 1 e 2 o fator de retardamento foi respectivamente igual 
a 1,4 e 1. Desta forma, considerando apenas o resultado da Coluna 2, verifica-se que não houve retardamento do persulfato em contato com o LV.

$$
R_{f} \frac{\partial C}{\partial t}=D_{x} \frac{\partial^{2} C}{\partial x^{2}}-v_{x} \frac{\partial C}{\partial x}-R_{f} \lambda C
$$

Sendo que,

$\mathrm{V}_{\mathrm{x}}$ : velocidade linear da água na direção $\mathrm{x}$;

$\mathrm{R}_{\mathrm{f}}$ fator de retardamento;

$\mathrm{D}_{\mathrm{x}}$ : coeficiente de dispersão; e

$\lambda$ : constante da taxa da reação;

$$
C(x, t)=\frac{C_{0}}{2} e^{\frac{x}{2 D_{X}}\left(v_{x}-U\right)} \operatorname{erfc}\left(\frac{x-U t / R_{f}}{2 \sqrt{D_{x} t / R_{f}}}\right)
$$

Sendo que, $\mathrm{U}={\sqrt{v_{x}^{2}+4 \lambda D}}_{x}$, e erfc() é a função erro complementar.

A seguir apresenta-se os resultados relativos a concentração de Alumínio aferidos ao longo da oxidação da Coluna 1 , juntamente com a variação do $\mathrm{pH}$ ao longo do tempo (Figura 40).

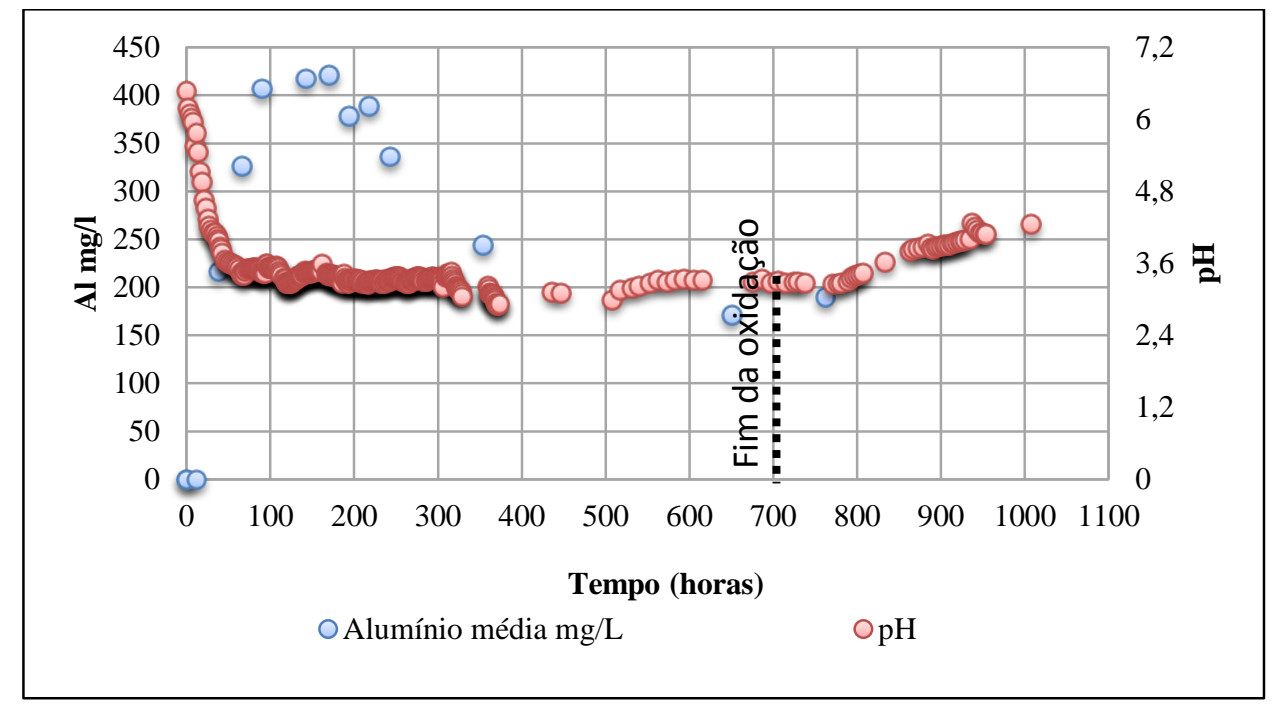

Figura 40 - Variação do pH e Alumínio ao longo do tempo na saída da Coluna 1.

Os valores de $\mathrm{pH}$, Eh e da temperatura da solução na saída da coluna foram monitorados por meio de um eletrodo multiparâmetro acoplado a uma célula de fluxo. A temperatura da solução ao longo do processo de oxidação variou entre 21 e $27^{\circ} \mathrm{C}$.

De acordo com a Figura 40, a elevação da concentração de alumínio ocorreu juntamente com a redução do $\mathrm{pH}$, sendo que a máxima concentração foi observada para valores de $\mathrm{pH}$ igual a 3, entre 90 e 110 horas, após este período apesar do $\mathrm{pH}$ ter se 
mantido constante, verificou-se a redução da concentração de alumino e posterior estabilização. Destaca-se também, o fato do valor de $\mathrm{pH}$ não ter retornado a condição inicial após aproximadamente $200 \mathrm{~h}$ da interrupção da injeção da solução de $14 \mathrm{~g} / \mathrm{L}$ de persulfato.

De acordo com a representação de Mason (1966), o comportamento da alumina e da sílica varia em função do pH (Figura 41). A sílica ( $\mathrm{SiO} 2)$ é solúvel em meio alcalino enquanto a alumina $\left(\mathrm{Al}_{2} \mathrm{O}_{3}\right)$ é solúvel tanto em meios com acidez elevada quanto meios extremamente alcalinos.

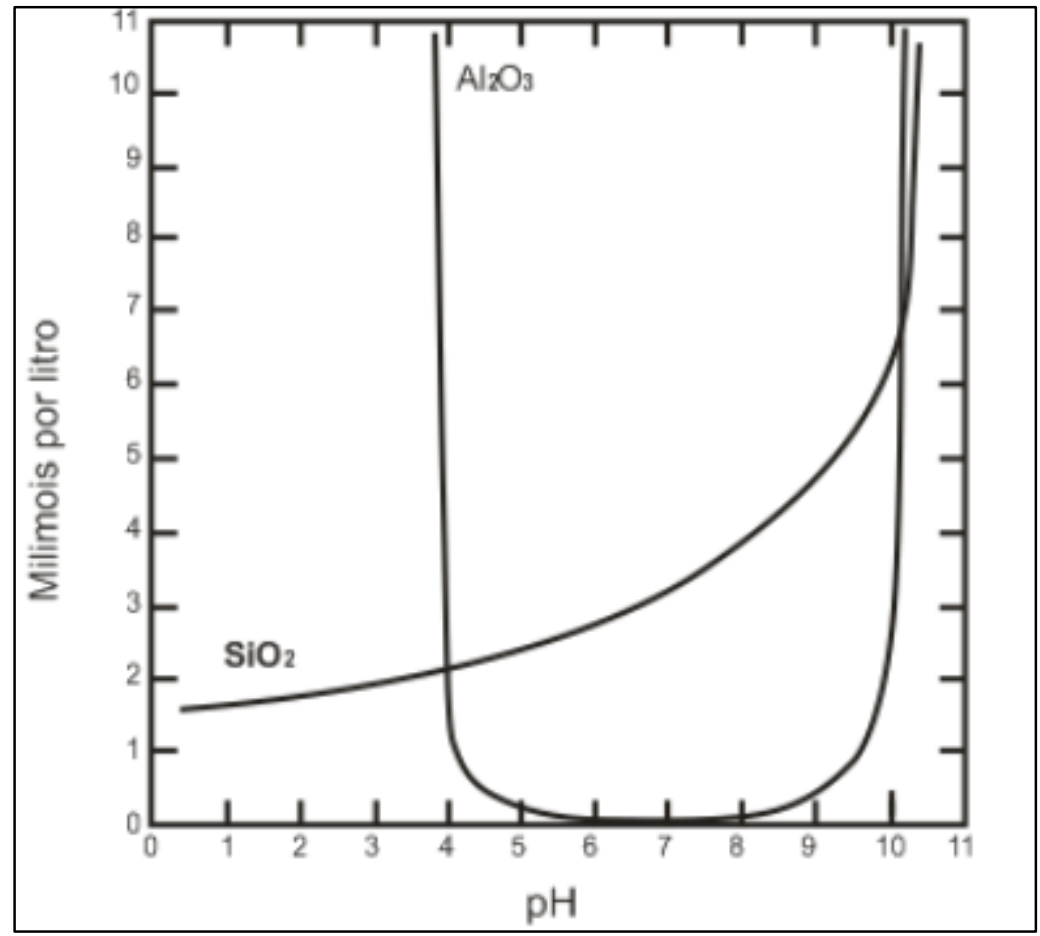

Figura 41 - Solubilidade da Sílica e da Alumina em função do pH (MASON,1966).

A representação da solubilidade da alumina elaborado por Mason (1966) corrobora a afirmação a respeito da dissolução da caulinita e gibbisita devido a acidificação do meio favorecendo a mobilização de alumínio para a solução. Isso também indica que o silício liberado pela dissolução de caulinita, tende a precipitar em $\mathrm{pH}$ ácidos podendo assim, alterar a porosidade do solo.

A fim de avaliar o comportamento do ferro, monitorou-se a concentração de ferro ao longo da oxidação da Coluna 1 (Figura 42). De acordo com os resultados, foi possível observar aumento na concentração de Ferro II na saída da coluna. Essa elevação de aproximadamente $0,6 \mathrm{mg} / \mathrm{L}$ nas primeiras 200 horas poderia estar relacionada a dissolução da caulinita e dos óxidos de ferro. Apesar da caulinita ser formada por tetraedros de silício e octaedros de alumínio, devido à substituição isomórfica, o ferro 
pode ser encontrado no centro de alguns octaedros ao invés do alumínio. Além da potencial participação do ferro na catálise, ou seja, favorecendo a formação de radicais livres, íons de sulfato podem ter se ligado ao ferro solúvel formando sais de sulfato ferroso (Figura 43) o qual foi lixiviado pela solução.

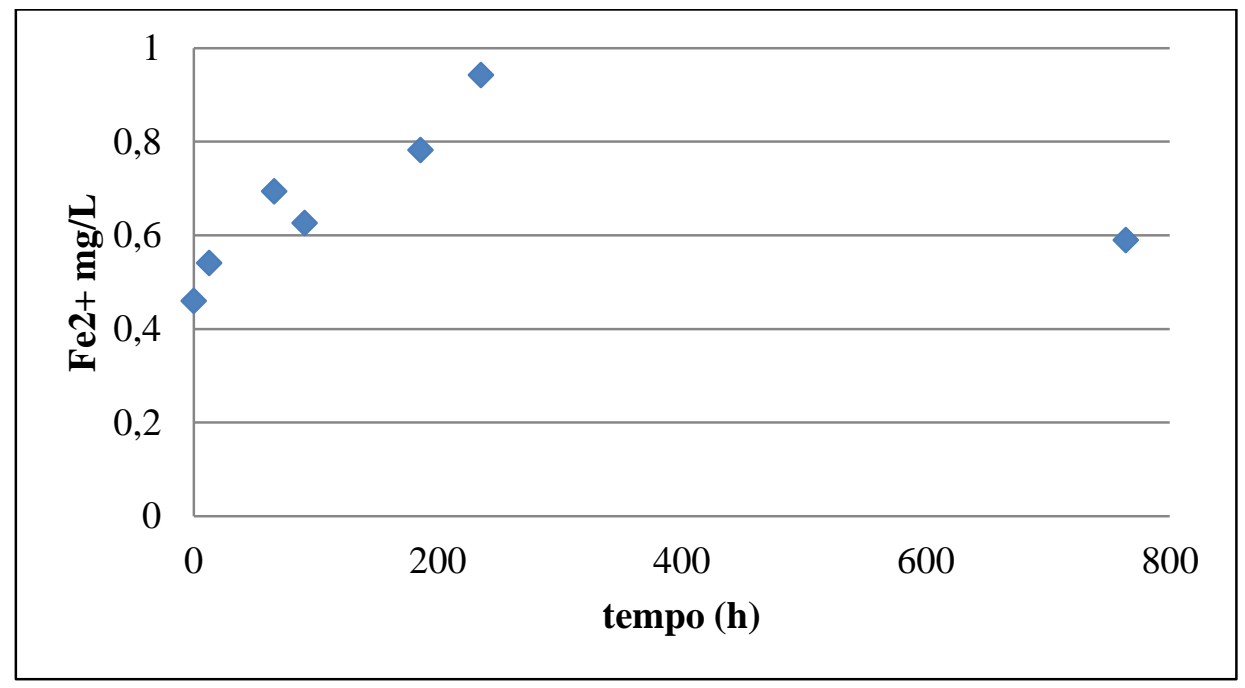

Figura 42 - Concentração de Ferro II ao longo do tempo Coluna 1.

Foi possível observar também a mobilização do ferro para a solução por meio da observação de cor esverdeada da solução na saída da coluna e posteriormente a precipitação de sais com ferro após a evaporação da água da solução (Figura 43).
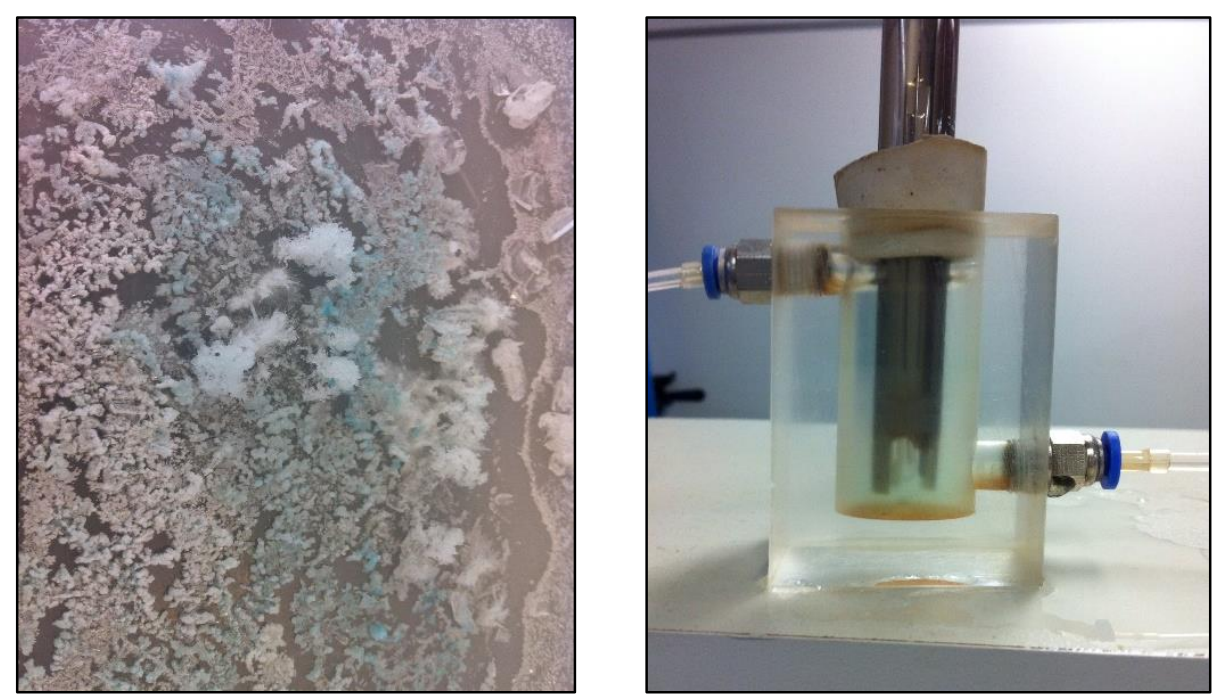

Figura 43 - Precipitação de sal a base de ferro (a esquerda) e observação de ferro em solução (a direita).

O gráfico da Figura 44 ilustra a condutividade hidráulica ao longo do tempo da Coluna 1 a qual foi possível de ser calculada por meio do monitoramento do gradiente hidráulico da coluna. Utilizando a equação do fluxo de Darcy obteve-se então a condutividade hidráulica (eq. 16). Observa-se uma tendência de decaimento da 
condutividade hidráulica nas 100 primeiras horas e após este intervalo uma variação na condutividade em aproximadamente uma ordem de grandeza.

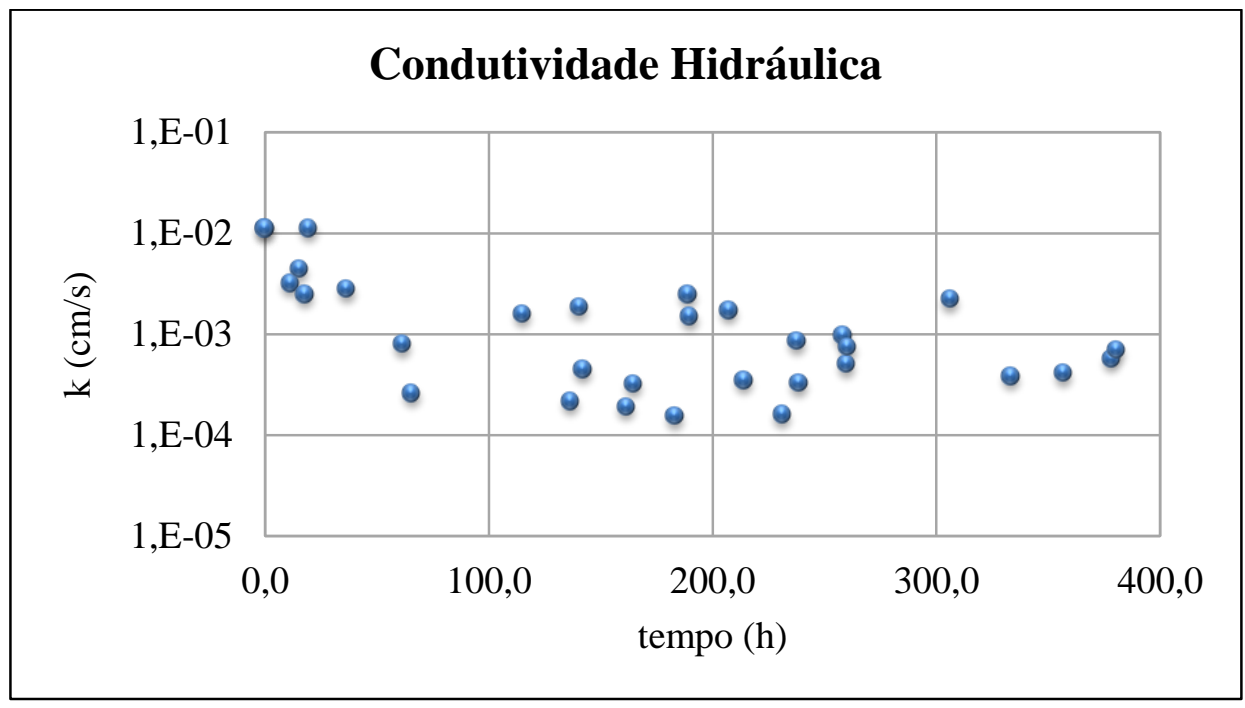

Figura 44 - Variação da condutividade hidráulica ao longo do tempo Coluna 1.

Acredita-se que a dissolução de alguns minerais, possa ter favorecido a formação de sulcos de dissolução ao longo da coluna acarretando numa distribuição não uniforme do fluxo pelos poros do solo e além disso, poderia eventualmente ainda deslocar partículas de argila inicialmente ligadas aos agregados para poros menores onde estes sólidos poderiam ficar alojados eventualmente reduzindo assim a porosidade do solo e consequentemente sua condutividade hidráulica. De acordo com os resultados, houve redução da condutividade hidráulica de forma heterogênea.

Por meio da regressão linear dos dados de pH e de condutividade hidráulica obteve-se $r^{2}$ igual a 0,85 e menor correlação com a concentração de alumínio $\left(r^{2}=0,71\right)$. Observando os dados do $\mathrm{pH}$ juntamente com os da condutividade hidráulica (Figura 45), nota-se que o decaimento da condutividade ocorreu nas primeiras 50 horas, ou seja, nos primeiros 2,5 números de poros quando a redução do $\mathrm{pH}$ foi drástica. Sendo assim, acredita-se que a alteração do $\mathrm{pH}$ tenha sido a principal responsável pelas alterações nas propriedades hidráulicas do solo e consequentemente no fluxo da solução. 


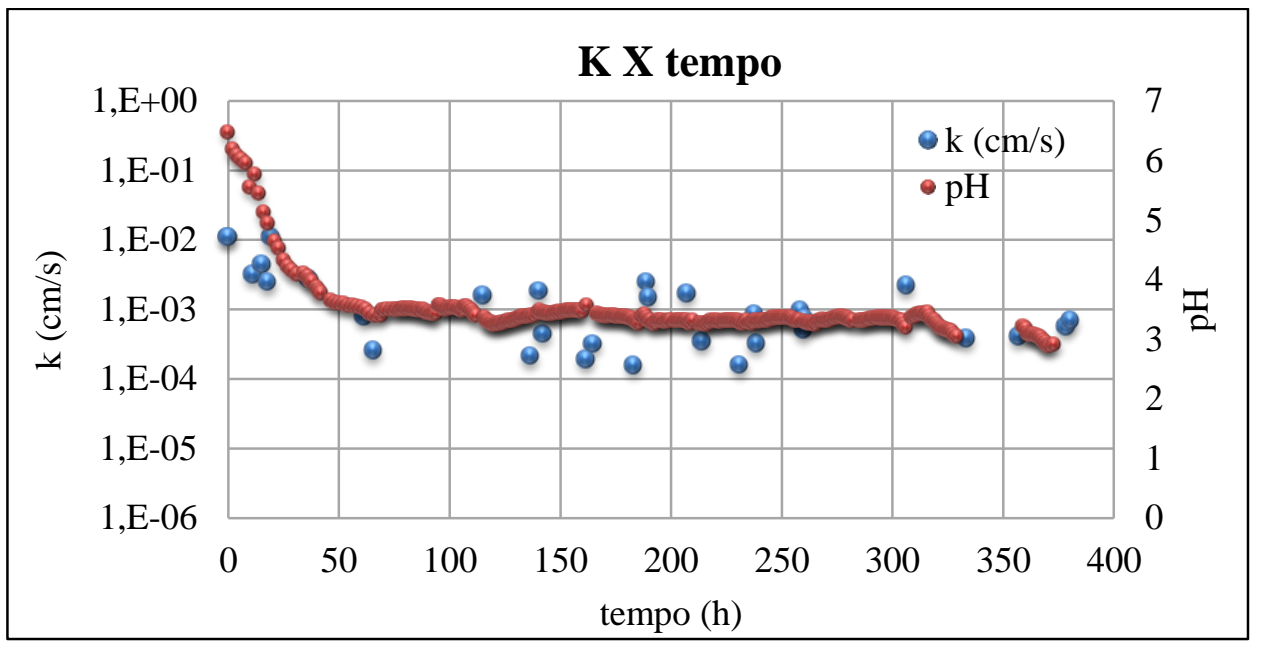

Figura 45 - Variação da condutividade hidráulica e do pH ao longo do tempo Coluna 1.

O traçador conservativo brometo foi passado novamente pelas Colunas 1 e $2 \mathrm{com}$ intuito de avaliar alterações no transporte da solução de brometo após o processo de oxidação. Os resultados do breakthrough do traçador inorgânico conservativo da Coluna 1 (Figura 46) e Coluna 2 (Figura 47) são significativamente diferentes dos resultados préoxidação. A alteração no comportamento da curva é evidenciada pelas irregularidades da curva especialmente entre o intervalo de 1,3 e 3,2 números de poros da Coluna 1 . O comportamento da curva neste intervalo indica que a solução atingiu $\mathrm{C} / \mathrm{C} 0$ igual a $1 \mathrm{em}$ determinado instante e logo depois este valor diminui provavelmente pelo fato das linhas de fluxos não terem sido uniformes dentro da coluna. Acredita-se que nos primeiros 1,9 números de poros a solução que sai percorreu caminhos com velocidades maiores.

Já para a Coluna 2, os ensaios 1 a 3 mostram a formação de caminhos com velocidades distintas a partir do instante em que o volume de solução de brometo injetada foi equivalente e maior do que 1 volume de poros.

A formação dos caminhos preferenciais pode estar relacionada a dissolução da caulinita de forma mais acentuadas em algumas regiões da coluna mais suscetíveis a este processo formando assim sulcos de dissolução. Estas regiões mais suscetíveis devem-se provavelmente devido a heterogeneidade do solo (exemplo: presença de carvão, raízes e eventualmente microfauna do solo) ou ainda podem estar relacionadas ao contato entre as paredes da coluna e o solo. A heterogeneidade do solo pode ter ocasionado diferentes zonas de suscetibilidade de dissolução dos minerais provocando a diminuição da condutividade hidráulica de forma desuniforme na coluna.

As Figuras 48 e 49 apresentam respectivamente, a situação da estrutura do solo presente dentro das Colunas 1 e 2 antes e após a oxidação. Após a realização dos experimentos de oxidação e breakthrough do brometo, as colunas foram abertas na sua 
porção superior e pode-se verificar a presença de fissuras no solo que indicam a formação de caminhos preferenciais (Figura 48 e 49), apesar de não se ter evidências de que as fissuras atingem todo o comprimento da coluna. Essas fissuras podem ter sido ocasionadas devido ao dimensionamento da coluna, sendo que a relação comprimento e diâmetro foi igual a 2 .

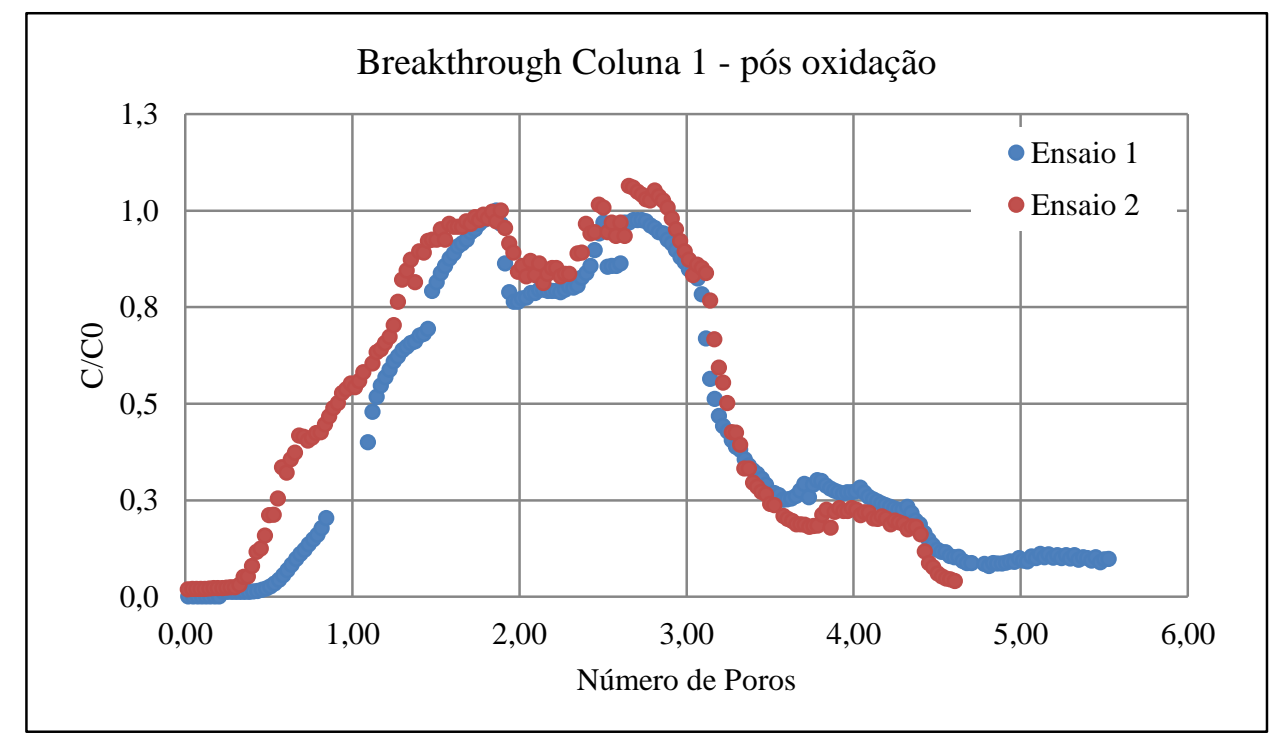

Figura 46 - Breakthrough brometo - Coluna 1 (Pós oxidação).

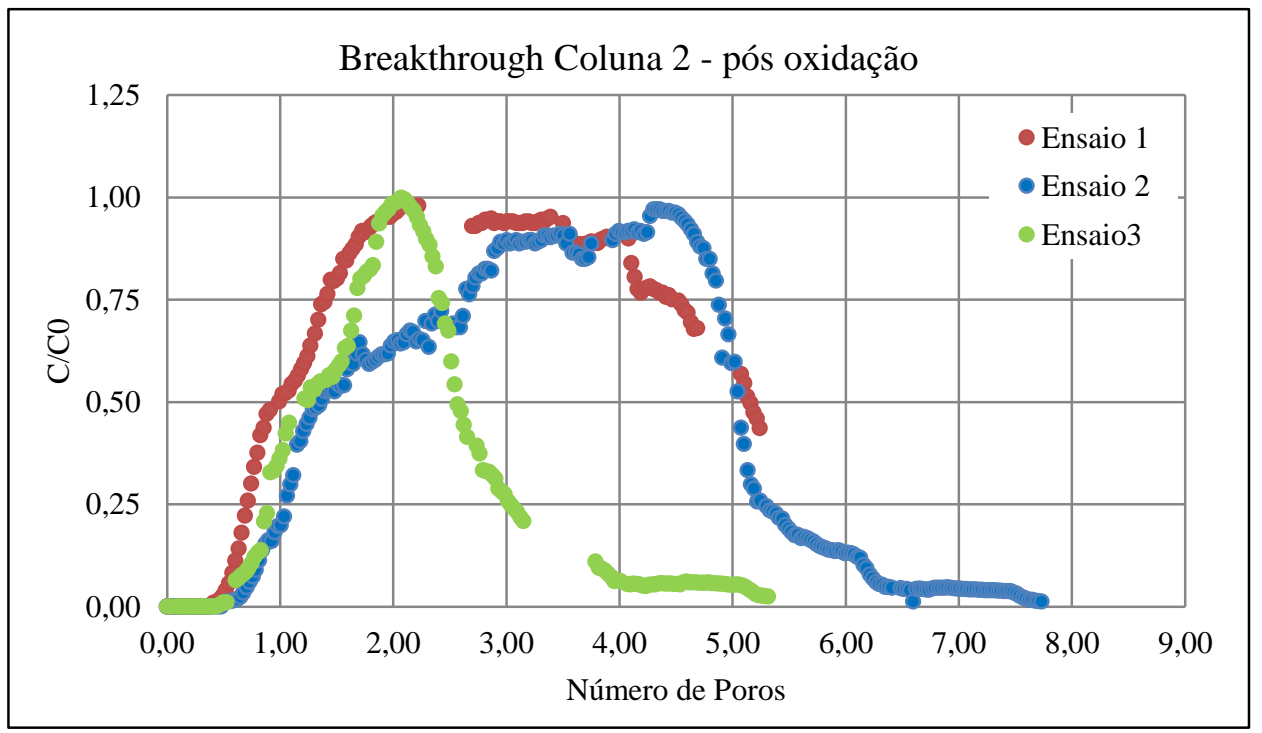

Figura 47 - Breakthrough brometo - Coluna 2 (Pós oxidação). 


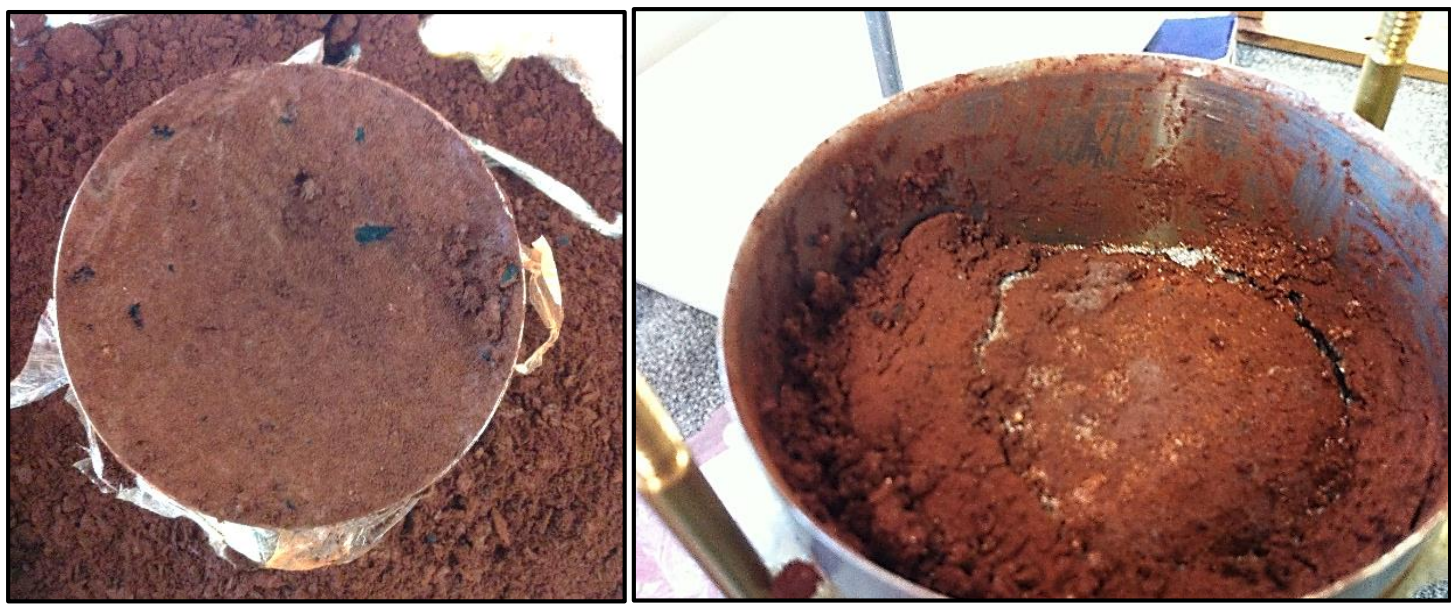

Figura 48 - Coluna 1 pré oxidação na base da coluna (esquerda) fissuras no solo da Coluna 1 pós oxidação no topo da coluna (direita).
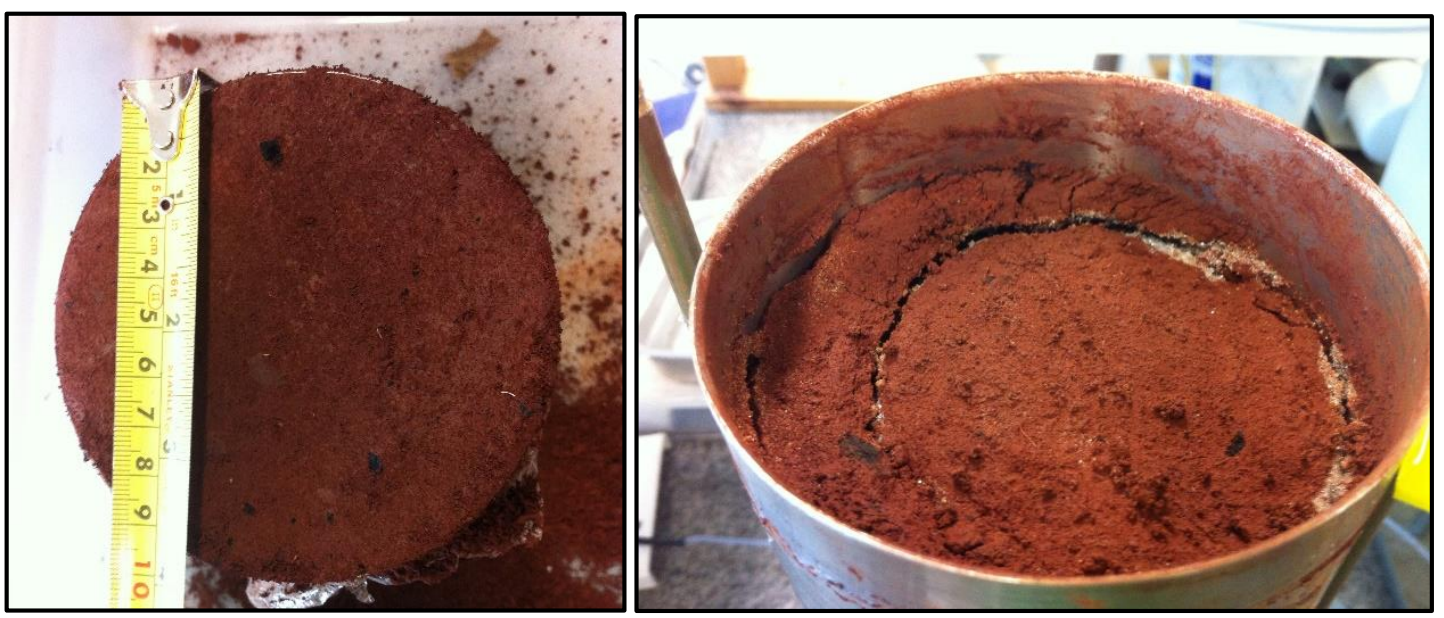

Figura 49 - Coluna 2 pré oxidação na base da coluna (esquerda) fissuras no solo da Coluna 2 pós oxidação no topo da coluna(direita).

Para a Coluna 1, o coeficiente de dispersão foi calculado através do modelo de Ogata \& Banks (Figura 50 e Figura 51). A velocidade média para os ensaios na Coluna 1 foi equivalente a $0,01 \mathrm{~cm} / \mathrm{s}$. Comparando o valor do coeficiente médio entre os ensaios pré e pós-oxidação, verifica-se que houve uma redução na dispersão já que o coeficiente de dispersão após a oxidação foi aproximadamente 3 vezes menor do que o coeficiente médio obtido antes da oxidação. Contudo, esta redução observada deve-se provavelmente devido a formação de caminhos preferenciais durante a oxidação.

O ajuste da solução analítica nos ensaios realizados após a oxidação foi pior do que aquele realizado antes da oxidação. Como o ajuste do modelo aos dados do ensaio não foi exato, a precisão na obtenção do coeficiente de dispersão foi prejudicada. 


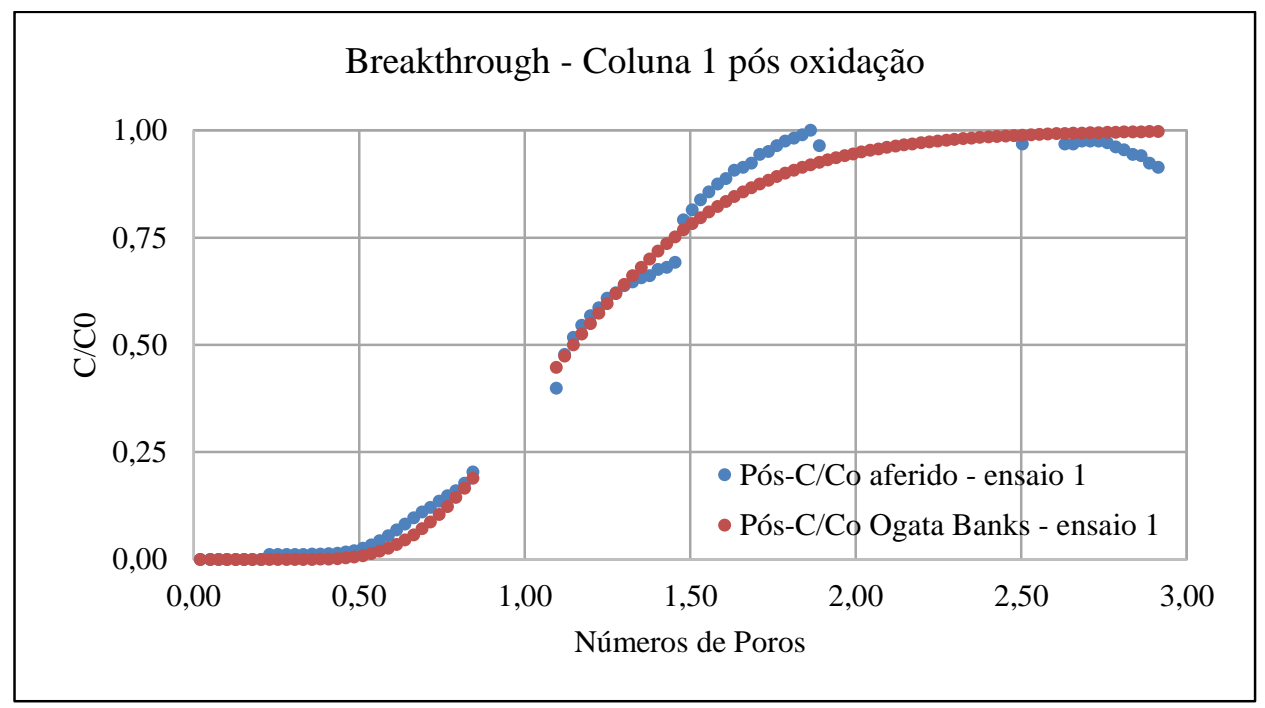

Figura 50 - Breakthrough brometo pós- oxidação na Coluna 1 (ensaio 1), aferido e calculado com modelo Ogata e Banks.

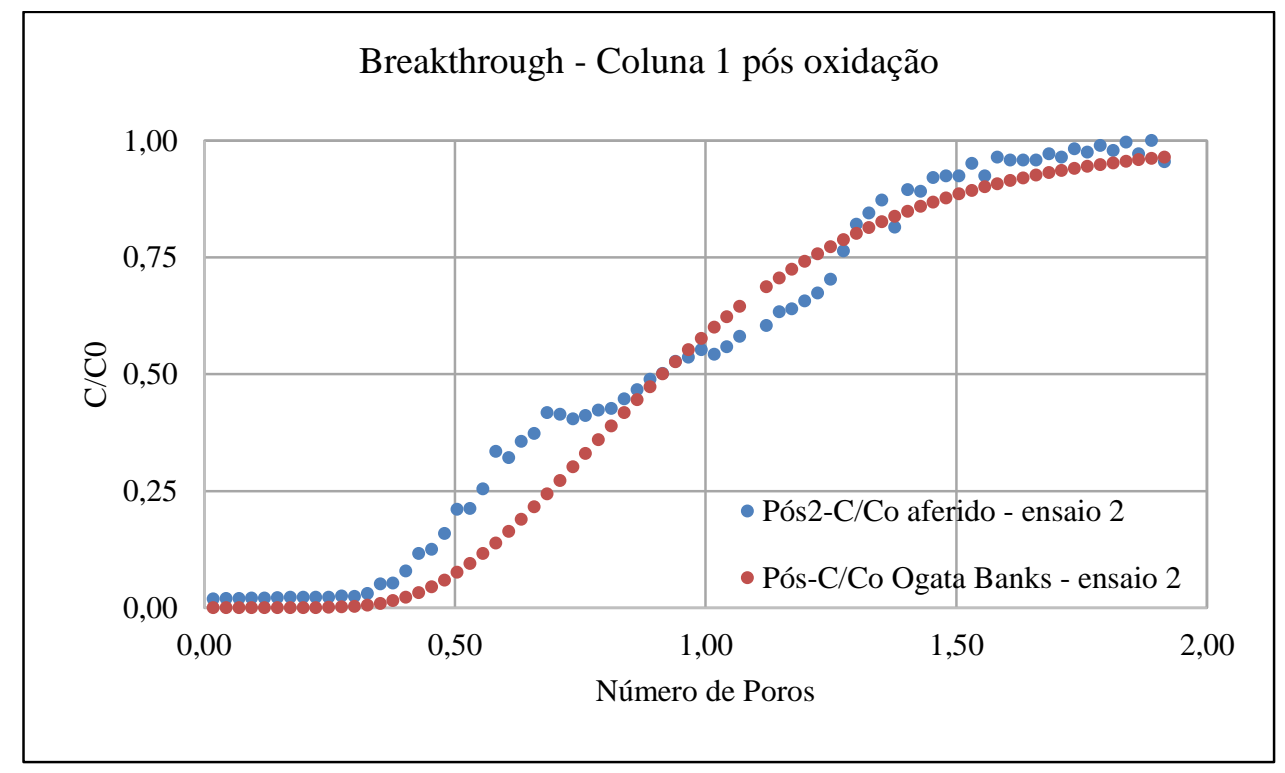

Figura 51 - Breakthrough brometo pós- oxidação na Coluna 1 (ensaio 2), aferido e calculado com modelo Ogata e Banks.

Com base no ajuste das curvas de Ogata \& Banks para a Coluna 2 (Figura 52 a 54) a uma vazão de injeção de $30 \mathrm{~mL} / \mathrm{h}$ e velocidade média de $0,01 \mathrm{~cm} / \mathrm{s}$, o coeficiente de dispersão foi equivalente a 0,017 (ensaio 1); 0,022 (ensaio 2) e $0,015 \mathrm{~cm}^{2} / \mathrm{min}$ (ensaio 3). Em média o coeficiente calculado após a oxidação foi igual a $0,018 \pm 0,003 \mathrm{~cm}^{2} / \mathrm{min}$. A razão entre os coeficientes médios de dispersão obtidos após e antes da oxidação foi equivalente a 0,8 ; ou seja, diferença pouco significativa indicando assim, que a oxidação do solo não alterou a dispersividade do meio. Os valores com os coeficientes de dispersão obtidos em ambas as colunas são apresentados na Tabela 34. 


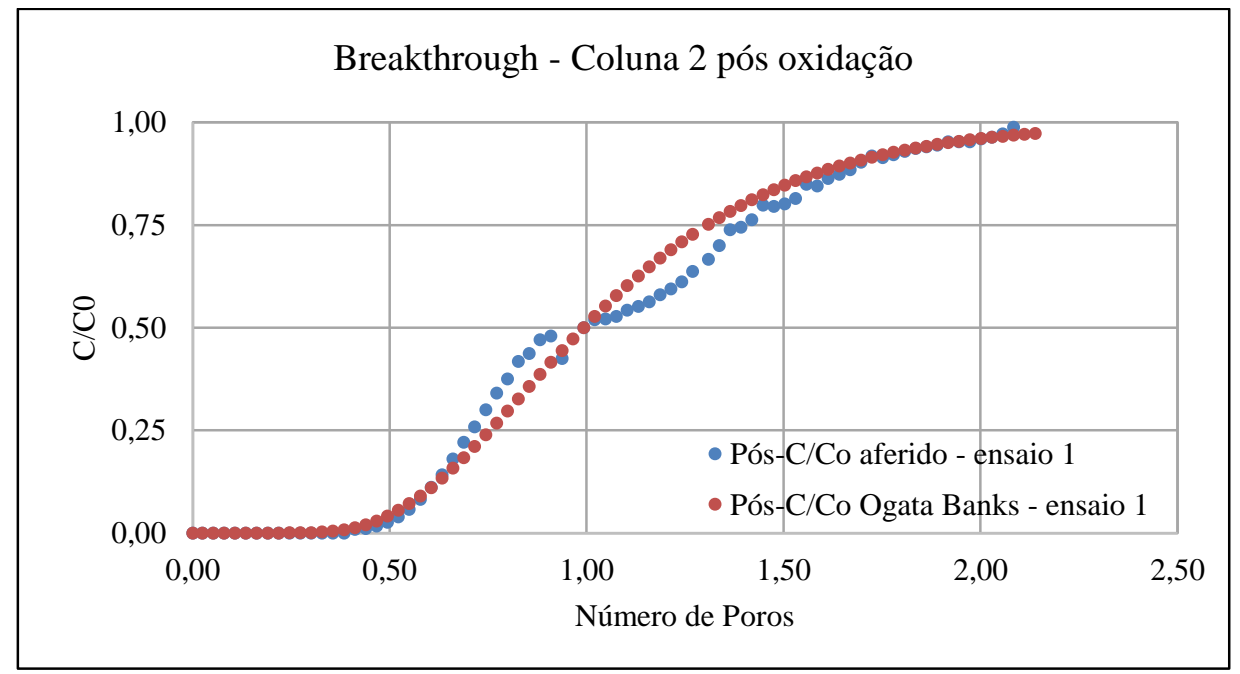

Figura 52 - Breakthrough brometo pós- oxidação na Coluna 2 (ensaio 1), aferido e calculado com modelo Ogata e Banks.

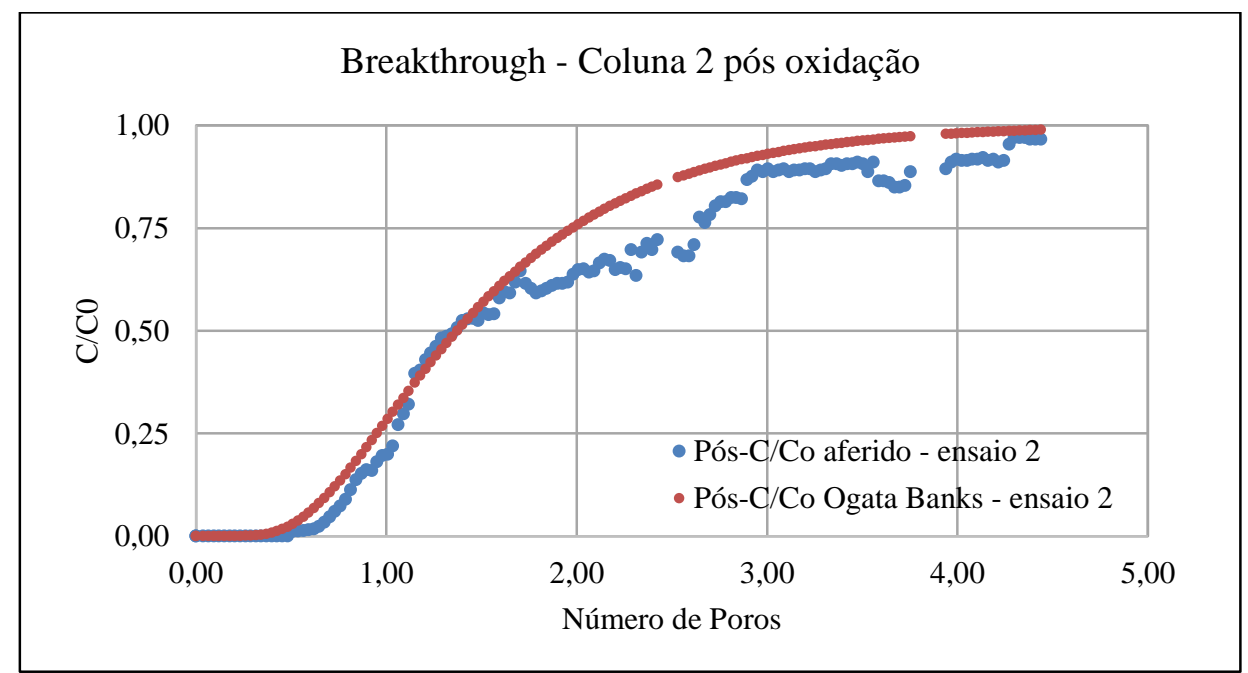

Figura 53 - Breakthrough brometo pós- oxidação na Coluna 2 (ensaio 2), aferido e calculado com modelo Ogata e Banks.

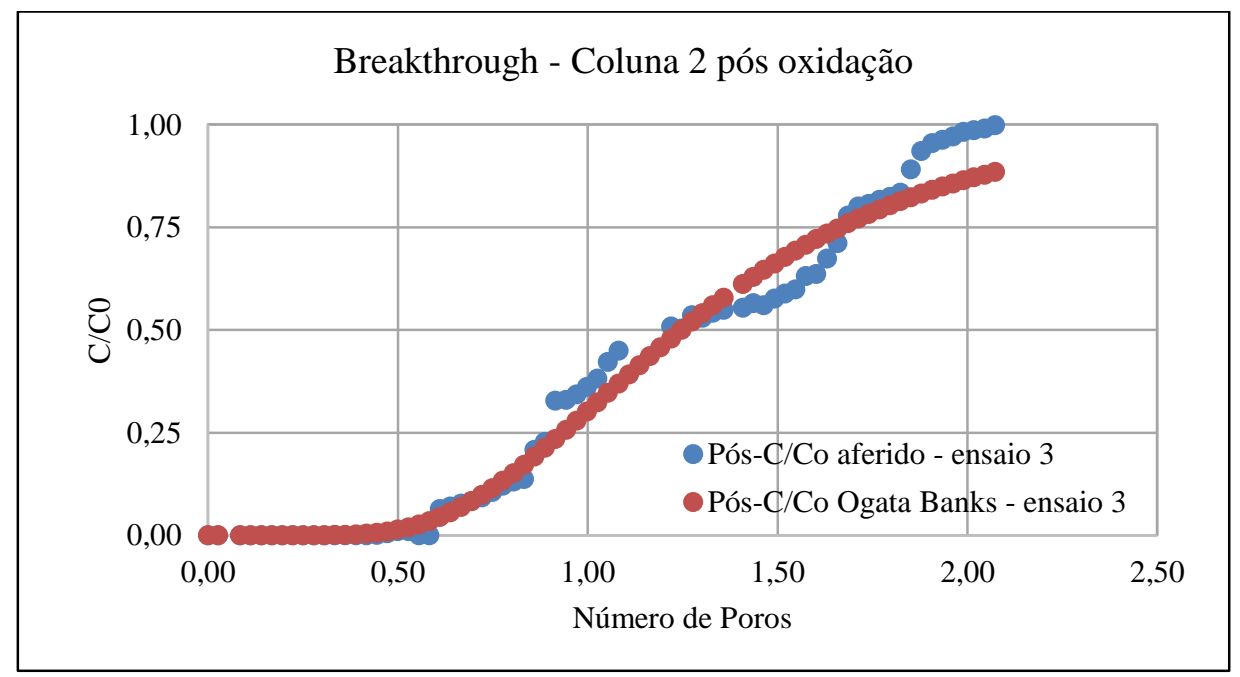

Figura 54 - Breakthrough brometo pós- oxidação na Coluna 2 (ensaio 3), aferido e calculado com modelo Ogata e Banks. 
Tabela 34 - Coeficientes de dispersão obtidos na Coluna 1 e 2 antes e após a oxidação

\begin{tabular}{|c|c|c|c|}
\hline \multirow{2}{*}{ Coluna } & \multirow{2}{*}{ Ensaios } & \multicolumn{2}{|c|}{$\mathrm{D}\left(\mathrm{cm}^{2} / \mathrm{min}\right)$} \\
\hline & & Pré & Pós \\
\hline \multirow{4}{*}{1} & 1 & - & 0,005 \\
\hline & 2 & 0,028 & 0,009 \\
\hline & 3 & 0,019 & \\
\hline & Média & 0,0235 & 0,007 \\
\hline \multirow{4}{*}{2} & 1 & 0,015 & 0,017 \\
\hline & 2 & & 0,022 \\
\hline & 3 & & 0,015 \\
\hline & Média & 0,015 & 0,018 \\
\hline
\end{tabular}




\section{CONCLUSÕES}

Com base nos resultados da presente pesquisa verificou-se que para elaboração de projetos de remediação realizados em áreas com presença de solos tropicais, os modelos e correlações apresentadas em pesquisas com a utilização de outros tipos de solos, não podem ser utilizadas já que a interação do oxidante com alguns tipos de solos encontrados em grande escala no Brasil (Latossolo Vermelho, Latossolo Vermelho Amarelo e Neossolo Quartzarênico) é diferente e mais intensa do que a interação observada entre o mesmo oxidante e alguns solos encontrados em regiões de clima temperado.

A diferença entre a interação dos oxidantes em contato com solos diferentes é devida principalmente a diferenças na mineralogia e na superfície específica dos grãos. Principalmente para o LV, a elevada área específica $\left(50 \mathrm{~m}^{2} / \mathrm{g}\right)$ e o elevado teor de argila $(\approx 70 \%)$ com alto teor de caulinita e óxidos e hidróxidos de ferro e alumínio, resultaram numa maior interação entre o solo e a solução oxidante.

Os solos avaliados já são ácidos e apresentam baixa capacidade de tamponamento quando o oxidante é adicionado, sendo que o LV foi aquele com maior capacidade de tamponar a solução e consequentemente foi o que apresentou maior interação com o oxidante. A alta solubilidade em condições ácidas de alguns minerais presentes no LV propiciou a destruição da caulinita e da gibbsita e óxidos de ferro, mobilizando o alumínio e ferro para a solução, o qual pode ser parcialmente adsorvido à superfície do solo. A oxidação do solo pelo persulfato atuou como um acelerador do intemperismo químico já que a acidez acentuada da solução intensificou a dissolução de minerais caulinita e gibbisita e dos óxidos de ferro amorfo mobilizando estes metais para a solução.

O alumínio mobilizado poderá permanecer adsorvido a superfície dos minerais ou poderá ser precipitado quando o $\mathrm{pH}$ da solução elevar para valores maiores do que 5 . Contudo, nos testes de coluna indeformada, o pH da solução na saída da coluna não ultrapassou 4,25 após aproximadamente 8,5 dias da interrupção da oxidação o que demonstra dificuldade no reestabelecimento das condições de equilíbrio iniciais. Sendo assim, em projetos de remediação por oxidação química onde se tem solos oxídicos com acentuada concentração de gibbisita ou ainda solos cauliníticos, o alumínio inicialmente presente no mineral poderá ser solubilizado e lixiviado para outras regiões do solo ou ainda para o aquífero o que não é satisfatório já que poderá elevar a níveis tóxicos a concentração de alumínio na água subterrânea e ainda alterar a condutividade do meio e 
eventualmente favorecer a formação de caminhos preferenciais. $O$ ideal para estes projetos é realizar sempre teste de bancadas e projetos pilotos de oxidação.

O ferro, assim como o alumínio, foi mobilizado para a solução nos testes de coluna, mas com concentração inferior àquela observada para o alumínio. $\mathrm{O}$ ferro observado na forma solúvel na saída da coluna pode estar relacionado aos óxidos de ferro que em parte encontravam-se inicialmente associados a caulinita e/ ou gibbisita formando microagregados de modo que, quando a estrutura destes minerais foi atacada estes óxidos podem ter sido liberados para a solução. O ferro solúvel pode também estar relacionado ao ferro presente no octaedro de alumínio da caulinita devido à substituição isomórfica. O ferro adsorvido a superfície do mineral pode ter atuado como catalisadores da reação favorecendo a formação de radicais livres de sulfato e persulfato, contudo apresentaram um consumo não finito do oxidante o que não é satisfatório para projetos de remediação. Além do ferro adsorvido, íons de ferro mobilizados para a solução podem ter atuado como catalisadores e redutores do persulfato. Solos com acentuada concentração de óxidos de ferro amorfo poderão apresentar maior interação com o oxidante do que solos com maior concentração de óxidos de ferro cristalino já que foi observada acentuada redução na concentração de ferro nos óxidos amorfos. Além disso, evidências mostram que a hematita teve maior participação na interação com o persulfato do que a goethita, contudo estudos adicionais devem ser realizados já que a identificação dos minerais foi realizada em amostras sem a concentração dos óxidos e sem a remoção dos filosilicatos dificultando assim a identificação dos óxidos.

Ressalta-se que outros metais sorvidos ao solo também poderão eventualmente ser mobilizados para a solução. De acordo com os resultados desta pesquisa, afirma-se que ensaios de mobilização de metais para a solução devem ser conduzidos a fim de avaliar a aplicabilidade desta tecnologia, pois além da presença de metais tóxicos sorvidos naturalmente aos minerais, diversas áreas possuem contaminação orgânica e inorgânica simultaneamente. Sendo assim, eventualmente a oxidação química in situ poderá tratar a contaminação orgânica, mas mobilizar metais tóxicos para a água subterrânea. A interação observada entre o persulfato e o solo poderá eventualmente ter comportamento diferente caso uma solução tampão seja misturada a solução oxidante a fim de evitar a acidificação da solução do solo e consequentemente a dissolução de alguns minerais.

$\mathrm{Na}$ fase sólida do solo, além dos minerais estão presentes compostos orgânicos os quais possuem elevada área específica e solubilidade. Entretanto, de acordo com os resultados verificou-se que o carbono orgânico não possui interação acentuada com o 
persulfato em solos com elevado teor de minerais (LV e LVA). O carbono orgânico nestes solos pode não ter sido oxidado devido à presença de complexos organo-minerias formado entre o composto orgânico e os óxidos de ferro. A ausência de concentrações significativas de óxido de ferro no NQ pode ter favorecido o ataque do persulfato no composto orgânico deste solo, reduzindo assim aproximadamente 50\% sua concentração. Devido à ausência de carbono inorgânico nos solos avaliados não foi possível avaliar a interação do persulfato com este tipo de carbono.

Além de alterações químicas nos solos, alterações nas propriedades hidráulicas foram observadas. Com base nos resultados dos experimentos com coluna indeformada, foi possível verificar que o coeficiente de dispersão não foi alterado drasticamente após a oxidação da Coluna 2, mas foram obtidas evidências da formação de fluxo heterogêneo após a oxidação do solo e a formação de fissuras no solo. Apesar da suspeita da formação caminhos preferenciais na porção superior das colunas, foi observada a redução da condutividade hidráulica após a oxidação em aproximadamente uma ordem de grandeza e de forma heterogênea ao longo do tempo. Houve redução da condutividade hidráulica provavelmente devido a desagregação dos grãos de argila alterando assim, a distribuição e formato dos poros. Essa desagregação pode ter sido ocasionada devido à diminuição dos óxidos de ferro inicialmente associados a caulinita como agente cimentante. A formação de caminhos preferenciais e a redução da condutividade hidráulica do solo podem reduzir a eficiência desta tecnologia, ao dificultar o acesso do oxidante ao contaminante. Para a remediação em subsuperfície, o desejável é que a solução se distribua de forma homogênea pelo solo, afim de se criar uma zona de oxidação, sendo assim quando caminhos preferenciais são formados evita-se que ocorra o espalhamento da solução, reduzindo consequentemente sua área de atuação.

Foi observado aumento de aproximadamente 23 vezes na constante da taxa de reação obtida no ensaio com a Coluna 2 em relação aos ensaios de batelada, sendo que a concentração inicial foi respectivamente igual a 9 e $14 \mathrm{~g} / \mathrm{L}$ para a Coluna 2 e o ensaio de batelada. Acredita-se que novos ensaios com oxidação do LV e outros solos encontrados em grande escala no território brasileiro devam ser conduzidos através de colunas e batelada com diferentes concentrações iniciais afim de validar a correlação criada entre a constante da taxa de reação obtida por meio dos dois experimentos adotados. É vantajosa a adoção de correlações entre estes experimentos para a obtenção dessa constante em projetos de remediação já que apenas ensaios de batelada poderiam ser conduzidos para estimar a depleção do oxidante persulfato no meio poroso. Ensaios com coluna se 
aproximam mais da situação observada em campo, contudo são mais dispendiosos e mais demorados, especialmente quando a coluna é indeformada. Sendo assim, torna-se possível eventualmente estimar o valor da constante da taxa de reação para coluna indeformada por meio da determinação da constante obtida pelo método de batelada, reduzindo assim os custos e o tempo necessário para esta avaliação. Contudo, a heterogeneidade observada no mesmo perfil de solo pode dificultar a obtenção de correlação entre as constantes.

\section{SUGESTÕES DE ESTUDOS FUTUROS}

Em virtude da heterogeneidade na estrutura e composição dos solos brasileiros, novos estudos com outros tipos de solos brasileiros com diferentes concentrações de ferro e formas de ferro devem ser realizados para que seja possível obter uma correlação representativa entre o ferro presente no solo e a constante da taxa de reação de decaimento do persulfato. Com essa correlação seria possível a partir da quantificação de um conjunto de parâmetros desenvolver um modelo capaz de estimar a depleção do oxidante em contato com o solo ao longo do tempo. Novos estudos devem ser realizados para avaliação da interação dos Latossolos com o persulfato e a formação de radicais livres. Além disso, pesquisas com a utilização de contaminantes orgânicos nos solos brasileiros devem ser conduzidas afim de avaliar a eficiência de degradação das substâncias em contato com os solos utilizados na presente pesquisa.

Além disso, acredita-se que estudos utilizando material coletado na zona saturada e modelos hidrogeoquímicos poderão contribuir para o entendimento e compreensão a respeito da interação do oxidante e diversos tipos de minerais. 


\section{REFERÊNCIAS BIBLIOGRÁFICAS}

AGÊNCIA NACIONAL DO PETRÓLEO. Anuário estatístico brasileiro do petróleo, gás natural e biocombustíveis. Ministério de Minas e Energia, Rio de Janeiro/RJ, p. $152,2011$.

AHMAD, M., TEEL, A. L., WATTS, R. J. Persulfate activation by subsurface minerals. Journal of Contaminant Hydrology v.115, p. 34-45, 2010.

AHNSTROM, Z.S.; PARKER, D .R. Development and assessment of a sequential extraction procedure for the fractionation of soil cadmium. Soil Science Society. American. v.63, p. 1650-1658, 1999.

ALLEONI, L.R.F.; CAMARGO, O.A. Ponto de efeito salino nulo: proposição de nomenclatura. Boletim Informativo da Sociedade Brasileira de Ciência do Solo, v.18, p.5-11, 1993.

ALLEONI, L.R.F.; CAMARGO, O.A. Pontos de efeito salino nulo de latossolos ácricos. Revista Brasileira de Ciência do Solo, v.18, p.175-180, 1994.

ALLEONI, L. R. F. Adsorção de boro em Podzólico e Latossolos paulistas. Tese de Doutorado, Escola Superior Luiz de Queiroz. Piracicaba, 1996.

ALVES, M. E. Atributos mineralógicos e eletroquímicos, Adsorção e dessorção de sulfato em solos Paulistas. Tese de doutorado. Escola Superior de Agricultura Luiz de Queiroz, ESALQ, Piracicaba, 2002.

ANDERSON, S.J.; SPOSITO, G. Cesium adsorption method for measuring accessible structural surface charge. Soil Science Society of America Journal, v.55, n.6. 1963.

APPELO, C.A.J., POSTMA, D. Geochemistry, groundwater and pollution. A. A. Balkema/ Rotterdam/ Brookfield. 2ed, 2005.

ASSIS, R.L.; LANÇAS, K.P. Avaliação dos atributos físicos de um Nitossolo Vermelho distroférrico sob sistema plantio direto, preparo convencional e mata nativa. Revista Brasileira de Ciência do Solo, v.29, p.437-445, 2005.

BARCELONA, M.J., HOLM, R.T. Oxidation-reduction capacities of aquifer solids. Environ. Sci. Technol. 25, 1565-1572, 1991.

BEERMEN, N. V.; BUURMAN, P. Soil formation 2.ed. Kluwer Academic Publishers, 2002.

BERTOLO, R. Notas de Aula 12/04/2012. Aluminossilicatos: Intemperismo de Silicatos. São Paulo: USP, 2013. Disponível em: 〈www.igc.usp.br〉. Acesso em: 02 jan. 2013.

BOHN, L. H.; MCNEAL, B. L.; O’CONNOR, G. A. Soil Chemistry. ed.3 John Wiley \& Sons, inc. New York, 2001.

BOSSI, M. L. Avaliação do impacto da oxidação química com persulfato em um latossolo Vermelho-Amarelo e um Neossolo Quartzarênico. Trabalho de conclusão 
de curso de Bacharelado em Ciências Ambientais - Universidade Federal de São Paulo, 2014.

BRAGATO, M.; TENÓRIO, J. A. S. Comparação entre Permanganato de Potássio e Peróxido de Hidrogênio na Descontaminação In-situ de Benzeno Em solo. Revista Brasileira de Ciências Ambientais v. 7, p. 15-20, 2007.

BRASIL, 1981a. Política Nacional do Meio Ambiente. Disponível em: <http://www.planalto.gov.br/ccivil_03/leis/16938.htm>. Acesso em: 18 jan. 2013.

BRASIL, 1981b. Resolução Conama 001/86. Disponível em: < http://www.mma.gov.br/port/conama/legiabre.cfm?codlegi=23>. Acesso em: 18 jan. 2013.

BRASIL, 1997. Resolução Conama 237/97. Disponível em: <http://www.mma.gov.br/port/conama/res/res97/res23797.html>. Acesso em: 18 jan. 2013.

BRASIL, 2001. Resolução Conama No 273/2001. Disponível em: <http://www.mma.gov.br/port/conama/res/res00/res27300>. Acesso em: 18 jan. 2013.

BROWN, G.S.; BARTON, L.L.; THOMSON, B.M. Permanganate oxidation of sorbed polycyclic aromatic hydrocarbons. Waste Management v.23, p. 737-740, 2003.

BRUSSEAU, M. L.; CARROLL, K. C.; ALLEN, T.; BAKER, J.; GUISEPPI, W.; HATTON, J.; MORRISON, C.; RUSSO, A.; BERKOMPASE, J. T. Impact of In Situ Chemical Oxidation on Contaminant Mass Discharge: Linking Source-Zone and Plume-Scale Characterizations of Remediation Performance. Environmental Science \& Technology. 45, p. 5352-5358, 2011.

BUXTON, G.V., GREENSTOCK, C.L., HELMAN, W.P., ROSS, A.B. Critical review of rate constants for reactions of hydrated electrons, hydrogen atoms and hydroxyl radicals (OH/O) in aqueous solution. Journal of Physical and Chemical Reference, v.513, 1988.

CAMARGO, M.N.; KLAMT, E.; KAUFFMAN, J.H. Classificação de solos usada em levantamento pedológico no Brasil. Boletim Informativo da Sociedade Brasileira de Ciência de Solo, v.12 n.1, 1987.

CAMARGO, O.A.; ALLEONI, L.R.F. Alguns métodos e terminologias em eletroquímica de solos. In: ALVAREZ, V.H.; FONTES, L.E.F.; FONTES, M.P.F. O solo nos grandes domínios morfoclimáticos do Brasil e o desenvolvimento sustentado. Viçosa: UFV, p.475-484, 1996.

CAMARGO, O.A.; MONIZ, A.C.; JORGE, J.A.; VALADARES, J.M.A.S. Métodos de análise química, mineralógica e física de solos do Instituto Agronômico de Campinas. (IAC, Boletim Técnico, 106). Campinas: Instituto Agronômico, 94p, 2009.

CHAOQUN, T., NAIYUN, G., YANG, D., WENLEI, R., SHENGDONG, Z., NAXIN, L. Degradation of antipyrine by heat activated persulfate. Separation and Purification Technology 109, p. 122-128, 2013. 
CHENG, H.; FROST, R. L.; YANG, J. Thermogravimetric analysis of selected coalbearing strata kaolinite. Thermochimica Acta, 507/8, p. 84-90, 2010.

CHESNIN, L.; YIEN, C.H. Turbidimetric determination of available sulfates. Soil Science Society of America Proceedings, v.15, n.1, p.149 - 151, 1950.

COHEN, R.M.; MERCER, J. W.; GREENWALD, R. M. BELJIN, M.S. Design guidelines for conventional Pump-and-Treat systems. In: Ground Water Issue, USEPA 540/S-97/504, 1997.

COMPANHIA AMBIENTAL DO ESTADO DE SÃO PAULO (CETESB, 2013), Texto Explicativo Relação de Áreas Contaminadas no Estado de São Paulo. São Paulo/SP, dezembro, 2013. Informações toxicológicas. Disponível em: <http://www.cetesb.sp.gov.br/tecnologia-ambiental/laboratorios/109-informacoestoxicologicas> Acesso em 25. Ago. 14.

COMPANHIA AMBIENTAL DO ESTADO DE SÃO PAULO (CETESB). Decisão de Diretoria No 263/2009/P. São Paulo/SP, 20 de outubro de 2009.

COMPANHIA AMBIENTAL DO ESTADO DE SÃO PAULO (CETESB). Texto Explicativo Relação de Áreas Contaminadas no Estado de São Paulo. São Paulo/SP, dezembro, 2012. Disponível em: < http://www.cetesb.sp.gov.br/userfiles/file/areascontaminadas/2012/texto-explicativo.pdf >. Acesso em: 21 mai. 2012.

SERVIÇOS GEOLÓGICOS DO BRASIL (CPRM), 2011. Mapas Geológicos estaduais. Disponível em:

<http://geobank.cprm.gov.br/pls/publico/geobank.documents.open_zipfile?id_sessao=2 0150528150102\&file=spaulo.zip > Acesso em: 19 jan 2014.

CRIMI, M. L.; SIEGRIST, R. L. Factors Affecting Effectiveness and Efficiency of DNAPL Destruction Using Potassium Permanganate and Catalyzed Hydrogen Peroxide. Journal of Environmental Engineering, p.1724 - 1732, 2005.

CRIMI, M. L.; TAYLOR, J. Experimental Evaluation of Catalyzed Hydrogen Peroxide and Sodium Persulfate for Destruction of BTEX Contaminants. Soil \& Sediment Contamination, v.16, p. 29-45, 2007.

DEMATTE, J. L. I.; MAZZA, J.A; DEMATTE, J.A.M. Caracterização e gênese de uma topossequência latossolo amarelo-podzol originado de material da formação barreiras - estado de alagoas. Sci. Agric., Piracicaba , v. 53, n. 1, 1996.

DOMENICO, P.A.; SCHWARTZ, F. W. Physical and Chemical Hydrogeology, $2^{\mathrm{a}}$ ed. John Wiley and Sons, New York, p.298-376, 1998.

ELLOY, F. C.; TEEL, A. L.; WATTS, R. J. Activation of persulfate by surfactants under acidic and basic conditions. Groundwater Monitoring \& Remediation 34, v.4, p. 51-59, 2014.

EMPRESA BRASILEIRA DE PESQUISA DE AGROPECUÁRIA (EMBRAPA, 1997). Manual de Métodos de Análise do Solo. 2ed. Centro Nacional de Pesquisa de Solos. Rio de Janeiro, 1997.

EMPRESA BRASILEIRA DE PESQUISA DE AGROPECUÁRIA (EMBRAPA, 1999). Sistema brasileiro de classificação dos solos. Rio de Janeiro, 1999. 
EMPRESA BRASILEIRA DE PESQUISA DE AGROPECUÁRIA (EMBRAPA, 2004). Produção de Sementes Sadias de Feijão Comum em Várzeas Tropicais. Disponível em: <http://sistemasdeproducao.cnptia.embrapa.br/FontesHTML/Feijao/FeijaoVarzeaTr opical/solos.htm> Acesso em 08. Ago. 2014.

EMPRESA BRASILEIRA DE PESQUISA DE AGROPECUÁRIA (EMBRAPA, 2006). NEOSSOLOS. In: Sistema brasileiro de classificação de solos. 2. ed. Rio de Janeiro p. 181-192. Disponível em: < http://www.agencia.cnptia.embrapa.br/gestor/solos_tropicais/catalogo/REC000gc3pwrr n02wx5ok01dx91c0pksbu0.html > Acesso em 08. Ago. 2014.

EMPRESA BRASILEIRA DE PESQUISA DE AGROPECUÁRIA (EMBRAPA, 2010). Conceito de fertilidade do solo e manejo adequado para as regiões Tropicas. Boletim de Pesquisa e Desenvolvimento (8). Disponível em: < http://www.infoteca.cnptia.embrapa.br/handle/doc/882598> Acesso em: 05 mai. 2014.

EMPRESA BRASILEIRA DE PESQUISA DE AGROPECUÁRIA (EMBRAPA, 2014). Extensão e distribuição dos solos. Disponível em:

<http://www.agencia.cnptia.embrapa.br/gestor/arroz/arvore/CONT000fesi63xh02wx5eo 0y53mhyx67oxh3.html> Acesso em: 20 ago. 2012.

EVANGELOU, V. P. Environmental soil and water chemistry: principles and applications. John Wiley \& Sons, p. 101-136, 1998.

EUSTERHUES, K.; RUMPEL, C.; KLEBER, I. K. K. Stabilisation of soil organic matter by interactions with minerals as revealed by mineral dissolution and oxidative degradation. Organic Geochemistry. v.34, p. 1591-1600, 2003.

FAGUNDES, J. R. T.; ZUQUETTE, L. V. Capacidade de sorção de materiais inconsolidados residuais da Formação Botucatu, região de São Carlos (SP), Brasil. Rev. Brasileira de Geociências, v. 39, n.3, 2009.

FEITOSA, F. A.C; MANOEL, F. J; FEITOSA, E. C; DEMETRIO, J. G. A. Hidrogeologia Conceitos e Aplicações 3ed. CPRM, Rio de Janeiro, p. 77, 2008.

FERRARESE, E., ANDREOTTOLA, G., OPREA, I.A. Remediation of PAHcontaminated sediments by chemical oxidation. Journal of Hazardous Materials v.152, p. 128-139, 2008.

FERREIRA, M.M.; FERNANDES, B., CURI, N. Influência da mineralogia da fração argila nas propriedades físicas de Latossolos da região sudeste do Brasil. R. Bras. Ciência do Solo, v.23, p. 515-524, 1999.

FERREIRA, S. M. Relação entre a espessura real e aparente da gasolina com etanol e da gasolina pura em colunas de laboratório. 107f. Tese - Instituto de Geociências da Universidade de São Paulo. São Paulo/SP, p. 35, 2003.

FETTER, C.W. Jr. Applied hidrogeology. 3rd Edition. Macmillan Publishing. New York/USA, p 691, 1994.

FETTER, C. W. Contaminant Hydrogeology. 2ed. Universidade de WisconsinOshkosh Waveland, p. 173-174, 287, 2008. 
FONTES, M.P.F. Iron oxide-clay mineral association in Brazilian Oxisols: a magnetic separation study. Clay and Clay Minerals, v.40, n.2, p.175-179, 1992.

FONTES, M.P.F. Caracterização da carga elétrica superficial de partículas do solo. In: CONGRESSO LATINO AMERICANO DE CIÊNCIA DO SOLO, 13, Águas de Lindóia, 1996. Solo-Suelo 96; anais. Águas de Lindóia: SBCS/SLCS, 1996.

FONTES, M.P.F.; WEED, S.B. Iron oxides in selected Brazilian Oxisols: I. Mineralogy. Soil Science Society of America Journal, v.55, 1991.

FONTES, M.P.F., WEED, S.B. Phosphate adsorption by clays from Brazilian oxisols: relationship with specific area and mineralogy. Geoderma, v.72, 1996.

FONTES, M.P.F.; CAMARGO, O.A.; SPOSITO, G. Eletroquímica das partículas coloidais e sua relação com a mineralogia de solos altamente intemperizados. Scientia Agricola, v. 58, 2001.

FROST, R. L.; CHENG, H.; YANG, J. Thermogravimetric analysis of selected coalbearing strata kaolinite. Thermochimica Acta, 507/8, p. 84-90, 2010.

FURMAN, O. S. TEEL, A. L. WATTS, R. J. Mechanism of base activation of persulfate. Environmental Science Technology. v. 44, p. 6423-6428, 2010.

GATIBONI L. C. Propriedades químicas do solo. Departamento de Solos da UFSM, 2000. Disponível em: < http://agronomiaufs.com.br/index.php/material-deaula/category/55-210404-fisica-do-solo?download=253\%3Afertilidade-do-soloquimica-do-solo-classificacao-do-solo-material-enviado-pelo-prof.> Acesso em 10 abr. 2013.

GENUCHTEN, M.TH V., ALVES, W.J.. Analytical solutions of the one-dimensional convective-dispersive solute transport equation. U.S. Dep. Agric. Tech., Bull, p. 149, 1982.

HARTOG, N. Reactivity of organic matter and other reductants in aquifer sediments. Ph.D. Tese Universidade Utrecht, Holanda, 2003.

HASELOW, J. S.; SIEGRIST, R. L.; CRIMI, M.; JAROSCH, T. Estimating the total oxidant demand for in situ chemical oxidation design. Remediation, p.5-16, 2003.

HOTZA, DACHAMIR. Artigo revisão: colagem de folhas cerâmicas. Cerâmica. vol.43, n.283-284. 1997. p. 159-166. ISSN 0366-

6913. http://dx.doi.org/10.1590/S0366-69131997000400002.

HUANG, K. C.; COUTTENYE, R. A.; HOAG, G. E. Kinetics of Heat-assisted Persulfate Oxidation of Methyl Tert-Butyl Ether (MTBE). Chemosphere, v. 49, p. 413-420, 2002.

HYUN, S. D.; KWON, Y. J.; KOANG, S. H. Effect of metal oxides on the reactivity of persulfate/ $\mathrm{Fe}$ (II) in the remediation of diesel-contaminanted soil and sand. Journal of Hazardous Materials. v.182, p. 933-936, 2010.

INDA JUNIOR, A. V.; KÄMPF, N.; GIASSON, E.; SILVA, J. A. L. Cinética da dissolução redutiva da goethita e hematita em solos poligenéticos. Ciência Rural, Santa Maria, v.35, n.3, p.553-561, 2005a. 
INDA JUNIOR, A. V.; KÄMPF, N. Variabilidade de goethita e hematita via dissolução redutiva em solos de região tropical e subtropical. Revista Brasileira Ciências Solo, v.29, p.851-866, 2005.

INSTITUTO BRASILEIRO DE GEOGRÁFIA E ESTATÍSTICA (IBGE). Manuais Técnicos em Geociências. 2ed. Rio de Janeiro, 2007.

INSTITUTO NACIONAL DE METROLOGIA NORMALIZAÇÃO E QUALIDADE INDUSTRIAL (INMETRO, 2010). Orientação sobre validação de métodos analíticos. Doq-gcre-008. ed.3, 2010. Disponível em:< http://www.inmetro.gov.br/Sidoq/Arquivos/CGCRE/DOQ/DOQ-CGCRE-8_03.pdf> Acesso em: 12. nov. 2012.

INTERSTATE TECHNOLOGY \& REGULATORY COUNCIL (ITRC, 2005). Technical and Regulatory Guidance for In Situ Chemical Oxidation of Contaminated Soil and Groundwater 2ed. Technical/Regulatory Guideline. Washington, D.C., 2005.

ITAMI, K., KYUMA, K. Dispersion behavior of soil from reclaimed lands with poor physical properties and their characteristics with special reference to clay mineralogy. Soil Sci. Plant Nutr. P.41-45, 1995.

JACOMINE, P. K. T. A nova classificação brasileira dos solos. Anais da Academia Pernambucana de Ciência Agronômica, Recife, v. 5 e 6, p.161-179, 2009.

JEFFERY, G. H.; BASSETT, J.; MENDHAM, J. DENNEY, R. C. Vogel Quantitative chemical analysis. ed.5. Longman Scientific \& Technical. New York, 1989.

JENNY, H. Factors of soil formation: a system of quantitative pedology. Foreword by AMUNDSON, R., Dover Publications, Inc., New York, 1994. Disponível em: <http://www.soilandhealth.org/01aglibrary/010159.Jenny.pdf> Acesso em: 18 mai. 2014.

JONES, R.C., UEHARA, G. Amorphous coatings on mineral surfaces. Soil Science Society. American. Proc., v.37, p.792 - 798, 1973.

JONES, L. J. The Impact of NOD Reaction Kinetics on Treatment Efficiency. Tese Waterloo, Ontario, Canada, 2007.

KEHEW, A. E. Applied Chemical Hydrogeology. Western Michigan University. Prentice Hall, p.83, 84, 2000.

KER, J.C. Mineralogia, sorção e dessorção de fosfato, magnetização e elementos traços de Latossolos do Brasil. Tese de Doutorado Universidade Ferederal de Viçosa, 1995.

KER, J. C. Latossolo do Brasil: Uma revisão. Geonomos, v.5, n.1, p. 17-40, 1997.

KILLIAN, P. F.; BRUELL, C. J.; LIANG, C.; MARLEY, M. C. Iron (II) Activated Persulfate Oxidation of MGP Contaminated Soil. Soil \& Sediment Contamination, v.16, p. 523-537, 2007. 
KIM, E.; ASARE, K. O. Dissolution windows for hydrometallurgical purification of metallurgical-grade silicon to solar-grade silicon: Eh-pH diagrams for Fe silicides. Hydrometallurgy v.127, p. 178-186, 2012.

KODAK. Titrimetric Determination of Persulfate in Persulfate Bleach ECR1125B, 2003. Disponível em:

<http://motion.kodak.com/motion/uploadedFiles/US_plugins_acrobat_en_motion_supp ort_processing_h243_ec1125.pdf>Acesso em: 10 nov. 2012.

KOLTHOFF, I. M.; MILLER, I. K. The chemistry of persulfate. I. The kinetics and mechanism of decomposition of persulfate ion in aqueous medium. Contribution from the school of chemistry of University of Minnesota, v. 73. p. 3055 - 3059, 1951.

KONDO, M. K. Gênese, morfologia e classificação do solo. Notas de Aula. Universidade Estadual de Monte Claros, Janaúba/MG, 2008.

LANGMUIR, D. Techniques of estimating thermodynamic properties of some aqueous complexes of geochemical interest. Chemical modeling in aqueous systems, speciation, sorption, solubility and kinetics, Washington, American Chemistry Society, 1979. p. 353387. Disponível em:

<http://www.infobibos.com/artigos/solos/eletroquimica/eletroquimica.htm>. Acesso em: 01 jun. 2013.

LEE, E. U.; FANG Y. C.; SEOL Y.; S C H W A R T Z F. W. Destruction Efficiencies and Dynamics of Reaction Fronts Associated with the Permanganate Oxidation of Trichloroethylene. Environmental Science of Technology. v.37, p. 2540-2546, 2003.

LEE, E. S.; WOO, N. C.; SCHWARTZ, F. W.; LEE, B. S.; LEE, K. C.; WOO, M. H.; KIM, J. H.; KIM, H. K. Characterization of controlled-release KMnO4(CRP) barrier system for groundwater remediation: A pilot scale flow-tank study. Chemosphere, v. 71, p. 902-910, 2008.

LEWIS, J.; SJÖSTROM, J. Optimizing the experimental desing of soil columns in saturated and unsaturated transport experiments. Journal of Contaminant Hydrology, v.115, p. 1-13, 2010.

LI, X. D.; SCHWARTZ, F. W. In Treating dense nonaqueous-phaseliquids (DNAPLs): Chemical oxidation and reactive barriers; Wickramanayake, G. B., Gavaskar, A. R., Gupta, N., Eds.; Columbus, p. 41-48, 2000.

LIANG, C.; BRUELL, C. J.; MARLEY, M. C.; SPERRY, K. L. Persulfate oxidation for insitu remediation of TCE. I.Activated by ferrous ion with and without a persulfate-thisulfate redox couple. Chemosphere v.55, p. 1213-1223, 2004.

LIANG, C.; LEE, I. L.; HSU, I. Y.; LIANG, C. P.; LIN, Y. L. Persulfate oxidation of trichloroethylene with and without iron activation in porous media. Chemosphere. v.70, p. 426-435, 2008.

LIANG, S. H.; KAO, C. M.; KUO, Y. C.; CHEN, K. F.; YANG, B. M. In situ oxidation of petroleum hydrocarbon contaminated groundwater using ISCO system. Water research v.45, p. 2496-2506, 2011. 
LIMA, C. E. P. Termoanálises de matéria orgânica e vulnerabilidade à contaminação por metais pesados de solos do estado de Minas Gerais. Teses Universidade Federal de Viçosa, Viçosa, p. 34, 63-64, 2010.

LINDSAY, W.L. Chemical equilibria in soils. New York, John Wiley and Sons, 449p, 1979.

LIU, H.; BRUTON, T. A.; DOYLE, F. M.; SEDLAK, D. L. In Situ Chemical Oxidation of Contaminated Groundwater by Persulfate: Decomposition by Fe(III)and Mn(IV)-Containing Oxides and Aquifer Materials. Environmental Science \& Technology. v.48, p. 10330-10336, 2014.

MAGALHÃES, F. Síntese e Caracterização de Óxidos de Ferro e Compósitos para Aplicações no Tratamento Redox de Efluentes Aquosos. Tese Departamento de Química Universidade Federal de Minas Gerais Instituto de Ciências Exatas, Belo Horizonte, 2008.

MASON, B. Principles of geochemistry. $3^{\text {a }}$ ed. New York, Wiley, p. 320, 1966.

MATTOS, I. L.; SHIRAISHI, K. A.; BRAZ, A. D.; FERNANDES, J. R. Peróxido de hidrogênio: importância e determinação. Quim. Nova, v. 26, n. 3, p. 373-380, 2003.

MESQUITA FILHO, M. V.; TORRENT, J. Phosphate sorption as related to mineralogy of a hydrosequence of soils from the Cerrado region (Brazil). Geoderma, v.58, p. 107-123, 1993.

MEURER, E. J. Fundamentos de Química do Solo. 4ed. Universidade Federal do Rio Grande do Sul. Evangraf. Porto Alegre, p. 111-112, 131, 2010.

MEZZALIRA, S. Descrição Geológica e geográfica das folhas de Piracicaba e São Carlos/SP. Instituto Geográfico e Geológico. Boletim 43, p.41, 1965.

MIYAZAWA, M.; PAVAN1, M. A.; OLIVEIRA, E. L.; IONASHIRO, M.; SILVA, A. K. Gravimetric Determination of Soil Organic Matter Brazilian Archives of Biology and Technology, v.43, n.5, p. 475-478, 2000.

MONIZ, A.C. Elementos de pedologia. Rio de Janeiro: Livros Técnicos e Científicos, 1975.

MUMFORD, K. G.; THOMSON, N. R.; ALLEN-KING, R. M. Bench-scale investigation of permanganate natural oxidant demand kinetics. Environ. Sci. Technol. v.39, n.8, p. 2835-2840, 2005.

NACHTIGALL, G. R.; NOGUEIROL, R. C.; ALLEONI, L. R.F. Formas de cobre em solos de vinhedos em função do $\mathbf{p H}$ e da adição de cama-de-frango. Pesquisa Agropecuária Brasileira. v.42, n.3, p.427-427, 2007.

NAVARRO, R. M. F.; LIN, S. W.; LÓPEZ, A. Z.; SICAIROS, S. P.; SOTO, E. R. A. R.; GÓMEZ, J. H. E. 1,4-Dioxane Degradation Using Persulfate Ion and Ag(I) Ion. J. Mex. Chem. Soc. v.57, p. 127-132, 2013.

NETTO, A.R. Influência da mineralogia da fração argila sobre propriedades físicoquímicas de solos brasileiros. Dissertação de Mestrado da Universidade Federal de Viçosa. Viçosa, 1996. 
NOGUEIROL, R. C.; ALLEONI, L. R. F. A.; NACHTIGALL, G. W. M. Sequential extraction and availability of copper in $\mathrm{Cu}$ fungicide-amended vineyard soil from Southern Brazil. Journal of Hazardous Material, v. 181, p.931-937, 2010.

OLIVEIRA, J. B. Mapa Pedológico do Estado de São Paulo. 1:500.000. Instituto Agronômico de Campinas. Campinas, 1999.

OLIVEIRA, E. Contaminação de aquíferos por hidrocarbonetos provenientes de vazamento de tanques de armazenamento subterrâneo. 1992. 112 f. Dissertação Instituto de Geociências da Universidade de São Paulo. São Paulo, 1992.

OSAKI, F. Calagem e adubação. Campinas: Instituto Brasileiro de Ensino Agrícola, p. 503, 1991.

PARDIECK, D. L.; A. BOUWER, E. J.; STONE, A. T. Hydrogen peroxide use to increase oxidant capacity for in situ bioremediation of contaminated soils and aquifers: A review. Journal of Contaminant Hydrology, v. 9, p. 221-242, 1992.

PEDRON, F. A. Mineralogia, morfologia e classificação de saprolitos e neossolos derivados de rochas vulcânicas no Rio Grande do Sul. Tese de Doutorado. Universidade Federal de Santa Maria, 2007.

PETRI, B. G.; SIEGRIST, R. L.; CRIMI, M. L. Effects of groundwater velocity and permanganate concentration of DNAPL mass depletion rates during in situ oxidation. Journal Environmental Engineer, 2008.

PEYTON, G. R. The free-radical chemistry of persulfate-based total organic carbon analyzes. Marine Chemistry, v.41, p. 91-103, 1993.

PIGNATEllO, J. J.; OLIVEROS E.; MACKAY, A. Advanced Oxidation Processes for Organic Contaminant Destruction Based on the Fenton Reaction and Related Chemistry, Critical Reviews. Environmental Science and Technology. v.36, n.1, 2006.

RAIJ, B. VAN. Propriedades eletroquímicas de solos. In: DECHEN, A.R.;

CARMELLO, Q.A.C. Simpósio avançado de química e fertilidade do solo, Campinas: Fundação Cargill, p.9-42, 1986.

RAIJ, B. V.; PEECH, M. Electrochemical properties of some Oxisols and one Alfisols of the tropics. Soil Science Society of America Proceedings, v.36, p.587-593, 1972.

RAIJ, B. V.; ANDRADE, J. C.; CANTARELLA, H.; QUAGGIO, J. A. Análise Química para avaliação da fertilidade de solos tropicais. Instituto Agronômico de Campinas. Campinas, 2001.

RAYMOND, M. F.; ROSSI, P.; HUNKELER, D. Investigation of virus attenuation mechanisms in a fluvioglacial sand using colum experiments. Microbiology Ecology, v. 49, p. 83-95, 2004.

REICHERT, J.M.; NORTON, L. D. Aggregate stability and rain impacted sheet erosion of air dried and prewetted clayey surface soil under intensive rain. Soil Scientific, v.158, p.159-169, 1994. 
RESENDE, M. Aplicações de conhecimentos pedológicos à conservação de solos. Inf. Agropecuária, v.11, p.3-18, 1995.

RODRIGUES, C. P. M. A influência das características do solo na remediação de solos contaminados através de processos oxidativos com persulfato e reagente de Fenton. Dissertação de Mestrado. Ciência Ambiental. São Paulo, 2006.

RONQUIM, C. C. Conceitos de fertilidade do solo e manejo adequado para as regiões tropicais. Embrapa Monitoramento por Satélite (Embrapa Monitoramento por Satélite. Boletim de Pesquisa e Desenvolvimento, 8). ISSN 1806-3322, 2010.

SCHWERTMANN, U. Solubility and dissolution of iron oxides. Plant and Soil, v.130, p.1-25, 1991.

SCHWERTMANN, U.; FECHTER, H. The influence of aluminium on iron oxides: XI. Aluminum-substituted maghemite in soils and its formation. Soil Science Society of America Journal, v.48, n.6, 1984.

SCHWERTMANN, U.; FECHTER, H. The point of zero charge of natural and synthetic ferrihydrites and its relation to adsorbed silicate. Clay Minerals, v. 17, n.4, 1982.

SHACKELFORD, C. D.; DANIEL, D. E. Diffusion in saturated soil. I: Background. Journal of Geotechnical Engineering, v. 117, n. 3, 1991.

SIEGRIST, R. L.; CRIMI, M.; SIMPKIN, T.J. In situ chemical oxidation for groundwater remediation, SERDP \& ESTCP - Department of Defense Strategic Environmental Research \& Department of Defense Environmental Security Technology Certification Program Arlington.VA-USA, p. 98-102; 233 - 234, 2011.

SILVA, V. Variáveis de acidez em função da mineralogia Do Solo. Dissertação da Universidade de Ciências Agrárias do Paraná. Curitiba, 2006.

SILVA, L. A.; TEIXEIRA, S. C. G.; PÉREZ, D. V.; MARQUES, M. R.C. Impacto f chemical oxidation on brazillian soils. Journal Brazilian Chemical Society, v. 23, n. 2, p.367 - 371, 2012.

SILVA, M.; SANTANA, G. P. Caulinita: estrutura cristalina, técnicas físicas de estudo e adsorção. Scientia Amazonia, v. 2, n.3, 54 - 70, Revista on-line http://www.scientia.ufam.edu.br ISSN:2238.1910, 2013.

SILVA, H. O. Impacto da oxidação química por persulfato nas propriedades de solos brasileiros. Trabalho de conclusão de curso de Bacharelado em Ciências Ambientais - Universidade Federal de São Paulo, 2014.

SILVEIRA, M. L; ALLEONI, G. A.; CONNOR, O.; CHANG, A. C. Heavy metal sequential extraction methods - A modification for tropical soils. Chemosphere. v.64, p.1929 - 1938, 2006.

ŠOLC, W.; GERZABEK, M. H.; LISCHKA, H.; TUNEGA, D. Wettability of kaolinite (001) surfaces - Molecular dynamic study. Geoderma v.169, p. 47 - 54, 2011.

SPARKS, D. L. Environmental soil chemistry. San Diego: Academic Press, 1995. 
SPARKS, D.L.; JARDINE, P.M. Comparison of kinetic equations to describe potassium-calcium exchange in pure and mixed systems. Soil Science, v. 135, 1984.

SPOSITO, G. Derivation of the Freundlich equation for ion exchange reactions in soils. Soil Science Society of America Journal, v. 44, 1980.

SPOSITO, G. Derivation of the Langmuir equation for ion exchange reactions in soils. Soil Science Society of America Journal, v. 43, 1979.

SPOSITO, G. The chemistry of soils. New York, Oxford University Press, 1989.

SRA, K.; THOMSON, N. R.; BARKER, J. F. Fate of persulfate in uncontaminated aquifer materials. Groundwater Quality Australia, 2007.

SRA, K.; THOMSON, N. R.; BARKER, J. F. Persistence of persulfate in uncontaminated aquifer materials. Environmental Science Technology. v.44, p. 3098-3104, 2010.

STRAUSS, R.; BRUMMER, G.W.; BARROW, N. J. Effects of crystallinity of goethite. II. Rates of sorption and desorption of phosphate. European Journal of Soil Science, v. 48, n.1, p. 101-104, 1997.

STUMM, W. Chemistry of the solid-water interface: processes at the mineralwater and particle-water interface in natural systems. New York: John Wiley \& Sons, 1992.

TAN, C.; GAO, N.; DENG, Y.; AN, N.; DENG, J. Heat-activated persulfate oxidation of diuron in water. Chemical Engineering Journal, v.203, p. 294-300, 2012.

TEEL, A. L.; CUTLER, L. M.; WATTS, R. J. Effect of sorption on contaminant oxidation in activated persulfate systems. Journal of Environmental Science and Health, v. 44, p. 1098-1103, 2009.

TEEL, A. L.; AHMAD, M.; WATSS, R. J. Persulfate activation by naturally occurring trace minerals. Journal of Hazardous Materials v. 196, p. 153-159, 2011.

TEIXEIRA-NETO, E.; TEIXEIRA-NETO, A. A. Modificação Química de Argilas: Desafios científicos e tecnológicos para obtenção de novos produtos com maior valor agregado. Quimica Nova, v. 32, p. 809-817, 2009.

TESSIER, A.; CAMPBELL, P. G. C.; BISSON, M. Sequential extraction procedure for the speciation of particulate trace metals. Chemosphere. v.51, p. 844-851, 1979.

TISDALL, J. M.; OADES, J. M. Organic matter and water-stable aggregates in soil. Journal of Soil Science, v.33, p. 141-163, 1982.

TSAI, T. T.; KAO, C. M.; HONG, A. Treatment of tetrachloroethylene-contaminated groundwater by surfactant-enhanced/BOF slag oxidation - A laboratory feasibility study. Journal of Hazardous Materials. v. 171, p. 571 - 576, 2009.

TSITONAKI, A.; PETRI, B.; CRIMI, M.; MOSBAK, H.; SIEGRIST, R, L.; BJERG, P. L. In situ chemical oxidation of contaminated soil and groundwater using persulfate: a review. Crit. Rev. Environmental Science Technology. v.40, p. 55-91, 2010. 
THOMSON, N. R. Natural Oxidant Interaction (NOI): A Paradigm Shift. 2010.

Disponível em:

<http://www.peroxychem.com/media/22895/FMC_Peroxygen_Talk_2010-

12_Natural_Oxidant_Interaction.pdf $>$ Acesso em: 12. Jun 2013.

UEHARA, G.; GILLMAN, G.P. Charge Characteristics of soils with variable and permanent charge minerals; I. Theory. Soil Science Society of America Journal, v.44, p.250-252, 1980.

UEHARA, G.; GILLMAN, G.P. The mineralogy, chemistry, and physics of tropical soils with variable charge clays. Colorado: Westview Press Inc., 1981.

UNITED STATE ENVIRONMENTAL PROTECTION AGENCY (USEPA, 2006). InSitu Chemical Oxidation. OMB n. 0704-0188. USA, 2006. Disponível em: < http://www.epa.gov/ada/gw/pdfs/insituchemicaloxidation_engineering_issue.pdf> Acesso em: 10 out. 2013.

UNITED STATE ENVIRONMENTAL PROTECTION AGENCY (USEPA, 2011). Direct Push Technologies. Disponível em:

<http://www.epa.gov/superfund/programs/dfa/dirtech.htm>. Acesso em: 08. Ago. 2014

UNIVERSIDADE FEDERAL DE LAVRAS (UFL, 2014a). Latossolo Vermelho

férrico. Disponível em: <http://www.dcs.ufla.br/Cerrados/Portugues/CLVFerrico.htm>. Acesso em: 20 nov. 2014.

UNIVERSIDADE FEDERAL DE LAVRAS (UFL, 2014b). Latossolo Vermelho não férrico. Disponível em: <

http://www.dcs.ufla.br/Cerrados/Portugues/CLVNFerrico.htm>. Acesso em: 20 nov. 2014.

UNIVERSIDADE FEDERAL DE LAVRAS (UFL, 2014c). Latossolo Vermelho e Vermelho-Amarelo. Disponível em:

<http://www.dcs.ufla.br/Cerrados/Portugues/CLVAmarelo.htm> Acesso em 20 nov. 2014.

USMAN, M.; FAURE, P., RUBY, C.; HANNA, K. Application of magnetite-activated persulfate oxidation for the degradation of PAHs in contaminated soils. Chemosphere, v. 87, p. 234 - 240, 2012.

VALENTIN, L. A. Boas práticas de laboratório: aplicação para avaliar o impacto ambiental causado pelo derrame de derivados de petróleo. Dissertação de Mestrado. Instituto de Química de São Carlos da Universidade de São Paulo. São Carlos, 2006.

XU, X. Interaction of Chemical Oxidants with Aquifer Materials. Tese Universidade de Waterloo, Engenharia Civil. Waterloo, Ontário, Canadá, 2006.

XU, X.; THOMSON N. R. A long-term bench-scale investigation of permanganate consumption by aquifer materials. Journal of Contaminant Hydrology n.110, p. 73 86, 2009.

XU, X.; THOMSON, N. R. Hydrogen peroxide persistence in the presence of aquifer materials Soil and Sediment Contamination. v.19, n.5, p. 602-616, 2010. 
WILLIAMS, E. C. Effect of Ethanol on BTEX Biodegradation in Aerobic Aquifer Systems. Dissertação de Mestrado em Ciências da Terra da Universidade de Waterloo, 2007.

YEN, A. C. H.; CHENB, K. F.; KAOC, C. M.; LIANGC, S. H.; CHEND, T. Y. Application of persulfate to remediate petroleum hydrocarbon-contaminated soil: Feasibility and comparison with common oxidants. Journal of Hazardous Materials. v.186, p. 2097-2102, 2011.

YOUSSEF, A. M.; El-NABARAWY T.; SAMRA, S. E. "Sorption properties of chemically-activated carbons 1 . Sorption of cadmium (II) ions". Colloids and Surfaces A: Physicochemical Engineering Aspects. Colloids and Surfaces. v.235, p. 153, 2004.

ZIN, Y. L.; GEURRA, A. B.; SILVA, A. C.; MARQUES, J. J.; OLIVEIRA, G. C.; CURI, N. Perfis de carbono orgânico do solo nas regiões sul e serra do espinhaço meridional, minas gerais: modelagem em profundidade. Revista Brasileira de Ciências do Solo, v.36, p. 1395 - 1406, 2012. 


\section{Anexo 1: Descrição Morfológica dos Solos}

\section{Latossolo Vermelho (LV)}

Data: 05/04/2012 e 06/12/2012

Localização: Rodovia Luiz de Queiroz, km 155; Piracicaba (SP); 2243’31,7’S e $47^{\circ} 35^{\prime} 9,1$ ' W

A 0-19 cm; bruno-avermelhado-escuro (entre 2.5YR 3/4 e 2.5YR 3/6, seca); argilosa; forte, média a grande, granular; muito dura; friável; plástica e pegajosa; presença abundante de raízes fasciculadas; atividade biológica intensa; transição ondulada e abrupta.

AB1 19-28 cm; bruno-avermelhado-escuro (2.5YR 3/4, seca); argilosa; maciça, forte compactação; plástica e pegajosa; presença rara a comum de raízes; transição ondulada e clara.

AB2 28-48 cm; bruno-avermelhado-escuro (2.5 YR 3/4, seca); argilosa, maciça, compactação média; plástica e pegajosa; presença rara de raízes; transição ondulada e gradual.

BA $\quad 48-75 \mathrm{~cm}$; bruno-avermelhado-escuro (2.5YR 2.5/4, seca); argilosa; maciça (60\%) ou fraca, pequena a média, bloco subangular (40\%); muita dura a dura; friável; plástica e pegajosa; presença rara de raízes; transição ondulada e gradual.

Bw 75 - 300+ cm; bruno-avermelhado-escuro (2.5YR 2.5/4, seca); muito argilosa, fraca, média a grande, bloco subangular, que se desfaz em forte, muito pequena, granular (microagregados); blocos subangulares: ligeiramente dura, friável; microagregados: dura; firme; muito plástica; pegajosa; presença rara de raízes.

OBS: A partir do $\mathrm{AB} 1$, presença comum a rara de volumes de carvão, $\mathrm{mm}$ a cm.

\section{Latossolo Vermelho-Amarelo (LVA)}

Data: 05/04/2012

Localização: Escola Superior de Agricultura Luiz de Queiróz - ESALQ; Piracicaba (SP); $22^{\circ} 43$ '2,8' S e 47³6'59,5' W

Ap 0-20 cm; bruno - avermelhado (5YR 4/4, seca); média; fraca, média a grande, granular; ligeiramente dura; muito friável; ligeiramente plástica e ligeiramente pegajosa; transição ondulada e abrupta. 
AB 20-34 cm; bruno-avermelhado-escuro (5YR 3/3, seca); média; moderada, média, bloco subangular; ligeiramente dura; muito friável; ligeiramente plástica e ligeiramente pegajosa; transição ondulada e clara.

Bw1 34-80 cm; bruno-avermelhado-escuro (5YR 3/4, seca); média; forte, pequena, granular (microagregados); macia, muito friável, ligeiramente plástica e ligeiramente pegajosa, transição ondulada e clara.

Bw2 80-100+ cm; bruno-avermelhado-escuro (5YR 3/4, seca); média; forte, pequena, granular (microagregados); ligeiramente dura; muito friável; ligeiramente plástica e pegajosa.

\section{Neossolo Quartzarênico (NQ)}

Data: 09/08/2012

Localização: Estação Experimental de Itirapina; São Carlos (SP); 22¹4’41,0” S e $47^{\circ} 51 ’ 35,8^{\prime \prime} \mathrm{W}$

A $0-5 \mathrm{~cm}$; bruno (entre $10 \mathrm{YR} 5 / 3$ e 4/3, seca); arenosa; fraca, média a pequena; granular; macia; muito friável; não plástica e não pegajosa; presença abundante de raízes; transição ondulada e abrupta.

AC $\quad 5-30 \mathrm{~cm}$; bruno (7.5YR 4/3, seca); arenosa; fraca, média, bloco subangular ou fraca, média, granular; ligeiramente dura; friável; não plástica e não pegajosa; presença comum a abundante de raízes; transição ondulada e clara.

CA $30-55 \mathrm{~cm}$; bruno (7.5YR 4/4, seca); arenosa; dominantemente grãos simples, com presença de poucos blocos subangulares ligados às raízes, fracos e pequenos; macia; friável; não plástica e não pegajosa; presença rara de raízes; transição ondulada e gradual.

C1 55-137 cm; bruno (7.5YR 5/4, seca); arenosa; grãos simples; não plástica e não pegajosa; transição ondulada e clara.

C2 137+ cm; bruno-forte (7.5YR 5/6, seca); arenosa; grãos simples; não plástica e não pegajosa. 
Anexo 2: Curvas de Titulação Potenciométricas

Ponto de Carga Zero do Solo

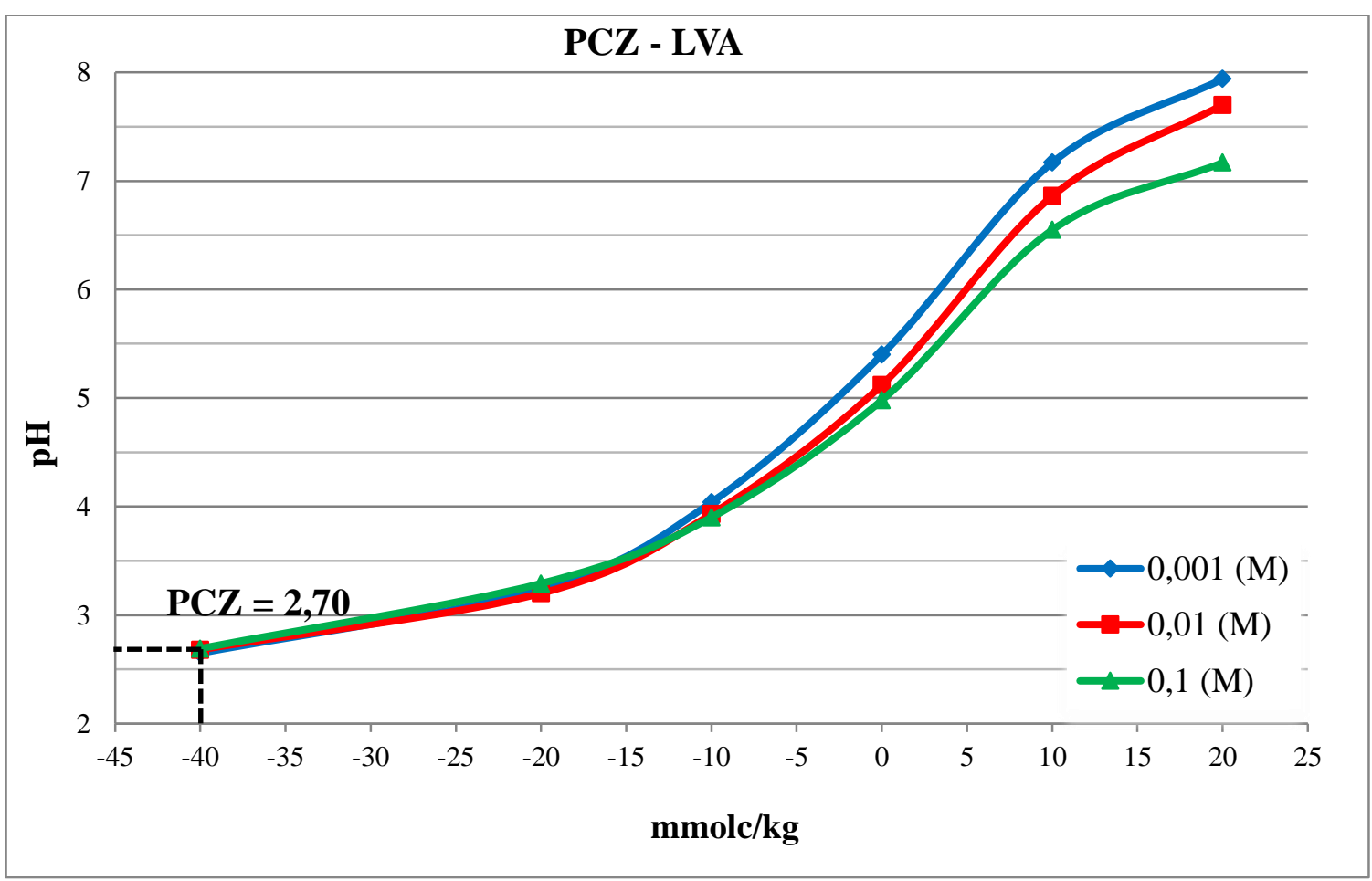

Figura 1: Ponto Efetivo Salino Nulo da amostra do solo LVA.

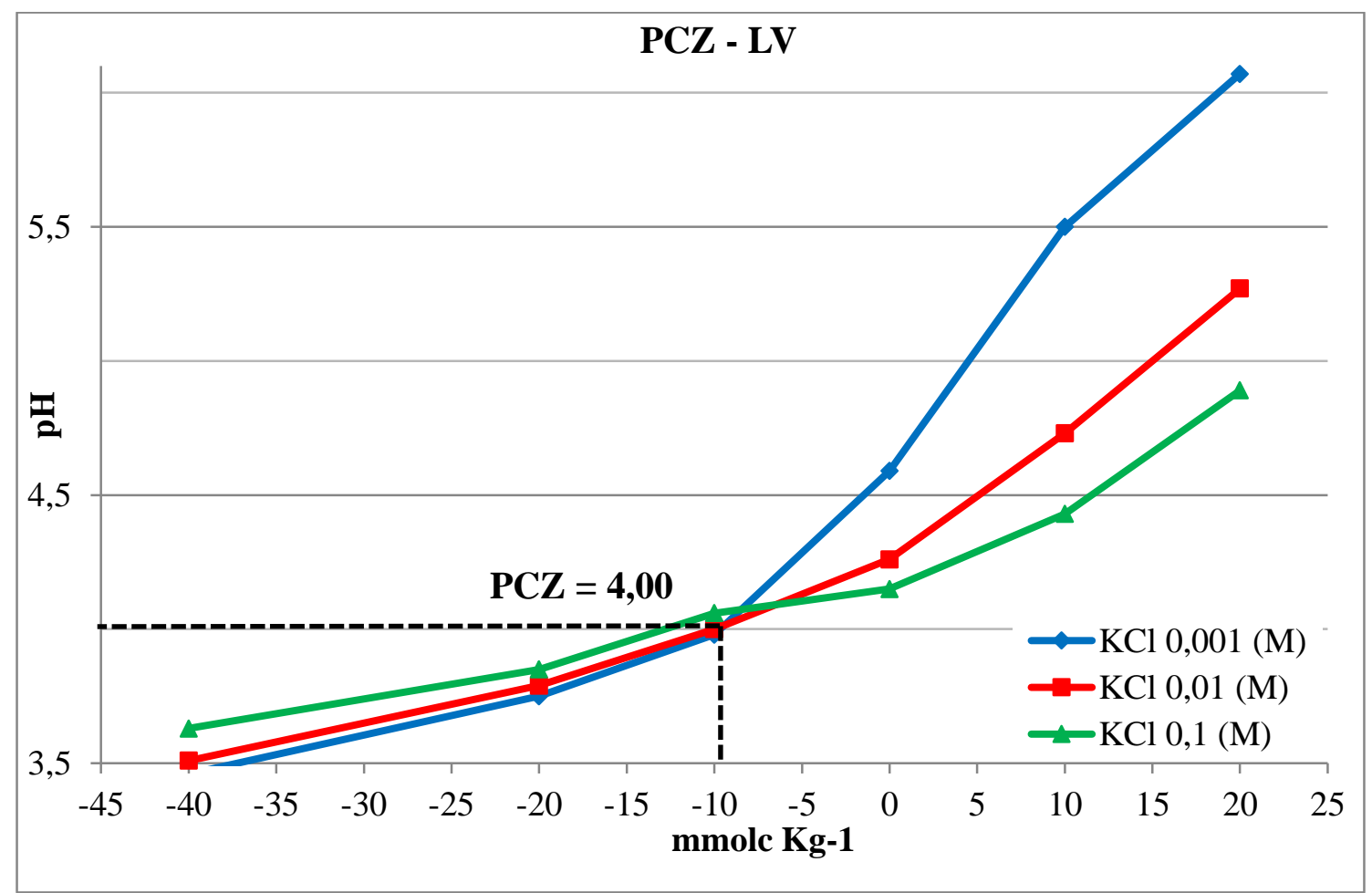

Figura 2: Ponto Efetivo Salino Nulo da amostra do solo LV 


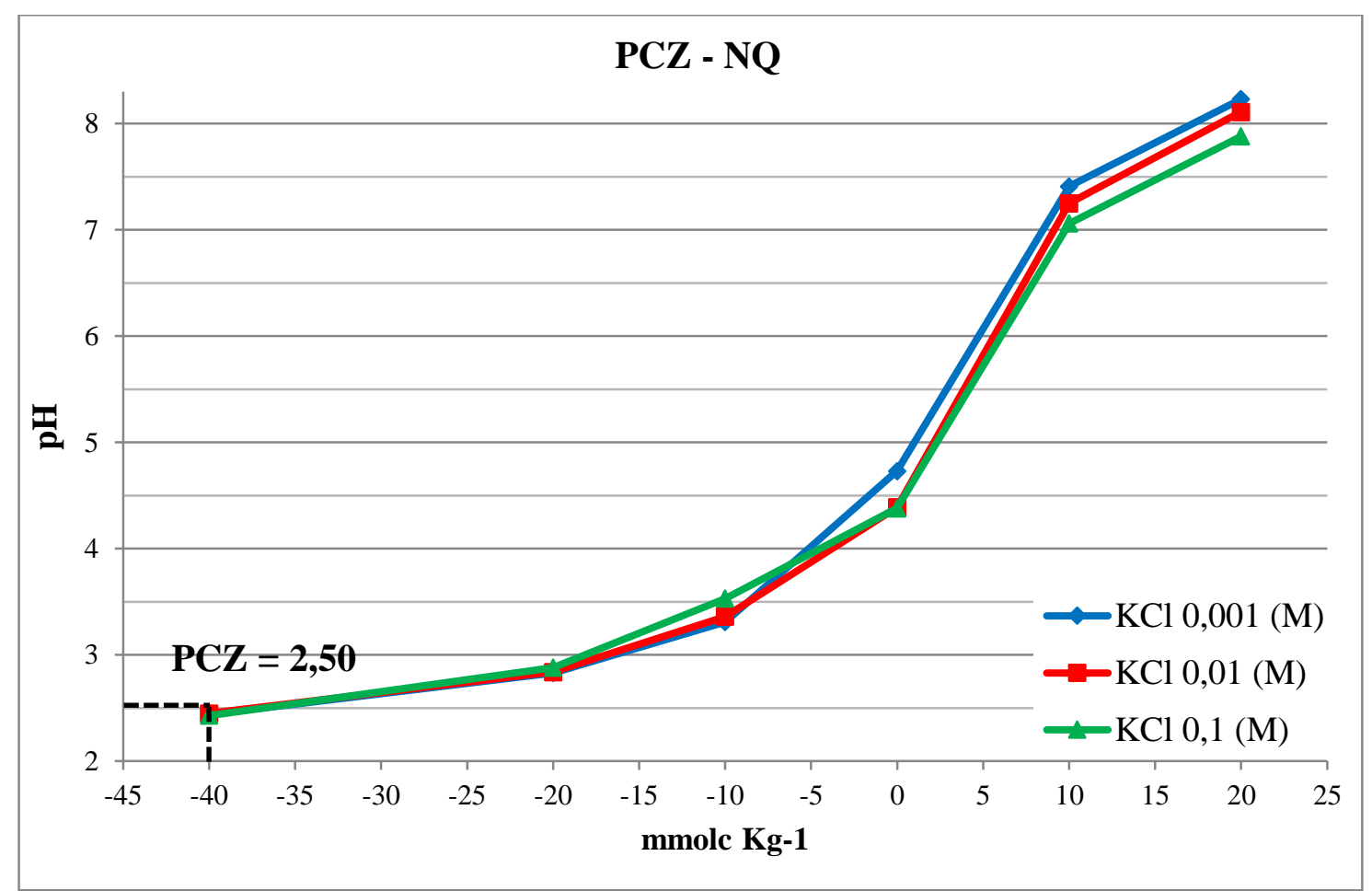

Figura 3: Ponto Efetivo Salino Nulo da amostra do solo NQ 